NATHÁLIA REGINA PINTO

A IMPORTÂNCIA DOS MARCOS REGULATÓRIOS NA PREVENÇÃO À CRIMINALIDADE ECONÔMICA

\author{
DISSERTAÇÃO DE MESTRADO
}

ORIENTADOR: PROFESSOR DOUTOR EDUARDO SAAD-DINIZ

UNIVERSIDADE DE SÃO PAULO

FACULDADE DE DIREITO

São Paulo - SP

2016 


\title{
A IMPORTÂNCIA DOS MARCOS REGULATÓRIOS NA PREVENÇÃO À CRIMINALIDADE ECONÔMICA
}

\begin{abstract}
Dissertação de Mestrado apresentada à Banca Examinadora da Faculdade de Direito da Universidade de São Paulo, como exigência parcial para a obtenção do título de Mestre em Direito, na área de Direito Penal, Medicina Forense e Criminologia, sob a orientação do Professor Doutor Eduardo Saad-Diniz.
\end{abstract}

FACULDADE DE DIREITO DA USP

SÃo PAULO 
PINTO, Nathália Regina.

A importância dos marcos regulatórios na prevenção à criminalidade econômica. São Paulo - SP, 2016.

190 p.; $30 \mathrm{~cm}$

Dissertação de Mestrado apresentada à Faculdade de Direito da Universidade de São Paulo

Orientador: Prof. Dr. Eduardo Saad-Diniz.

1.Globalização. 2.Marcos Regulatórios. 3.Direito Penal. 4.Prevenção. 5.Governança, Riscos e Compliance 
Banca Examinadora

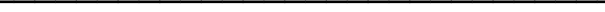




\section{AGRADECIMENTOS}

Acredito que este momento dos agradecimentos tenha sido pensado para que possamos expressar nossa gratidão aqueles que nos ajudaram a pensar, trabalhar, pesquisar e desenvolver a pesquisa da melhor forma possível. A lista talvez não traga todos que participaram deste momento, mas traz as pessoas que, com certeza, foram essenciais para o resultado.

Agradeço ao meu irmão, Ernesto, pelo apoio, com todos os seus significados possíveis, existentes e que ainda sejam inventados.

À minha mãe, Miriam, por tudo.

Ao meu irmão, Pedro, por sua conversa leve, preocupação e afeto.

Ao meu irmão, Sérgio, pelo incentivo e apoio.

Ao Rafael, pelo companheirismo e carinho incondicionais.

Às queridas Aline, Mayara, Renata e Viceza, amizades da vida toda.

Aos queridos Jéssica, Theuan e Fábio por serem sempre tão especiais.

Ao Gustavo e Ana Cristina pela amizade e conhecimento compartilhados.

Ao querido Prof. Eduardo Saad-Diniz pelos ensinamentos na graduação, pela oportunidade, confiança, ensinamentos, amizade e apoio.

Ao Prof. Victor Gabriel Rodriguez, professor que me acompanha desde a graduação, responsável pelo primeiro encantamento que tive com o direito penal. Por toda sua participação na pesquisa e na qualificação.

Ao Prof. Renato de Mello Jorge Silveira por ter aberto as portas da Faculdade de Direito com o privilégio de acompanhar suas aulas na monitoria e, especialmente, pelas contribuições feitas na qualificação.

Em memória ao meu pai. Sempre.

Muito obrigada. 


\section{RESUMO}

PINTO, Nathália Regina. A importância dos marcos regulatórios na prevenção à criminalidade econômica. Dissertação. Faculdade de Direito, Universidade de São Paulo, São Paulo, 2016.

$\mathrm{O}$ atual momento da globalização pode ser caracterizado pela integração de mercados e economias, cujas operações complexas e o grande volume de informações demandam regras e procedimentos próprios e especializados. Com fraudes bilionárias e crises que se espalham sem reconhecer fronteiras, o direito penal expande-se e passa a ser considerado como uma forma de evitar a repetição destes erros. Cresce, assim, a demanda por uma flexibilização dos ordenamentos nacionais e um agir conjunto de Estados e empresas. O alinhamento destas condutas resulta em medidas preventivas estabelecidas por diferentes marcos regulatórios, que estabelecem a importância de avaliações de riscos, medidas de governança corporativa e programas de compliance na implementação de uma nova cultura de ética e transparência nos negócios.

Palavras-chave: globalização; marcos regulatórios; direito penal; prevenção; governança, riscos e compliance. 


\begin{abstract}
PINTO, Nathália Regina. A importância dos marcos regulatórios na prevenção à criminalidade econômica. Dissertação. Faculdade de Direito, Universidade de São Paulo, São Paulo, 2016.

The present time of globalization can be described by a market and economic integration, which is made up by complex operations and a large amount of information that demand specific and specialized rules and procedures. Considering billionaire frauds and crisis spread worldwide, the criminal law expands and is regarded as the way to avoid repetition of this kind of error. As a result, grows the demand for a flexibilization of national legal orders and for a joint action between States and companies. The alignment of conducts results in preventive measures provided by different regulatory landmarks that determine the importance of risk management, corporate governance and compliance in the implementation of a new culture of ethics and transparency in business.
\end{abstract}

Keywords: Globalisation; regulatory landmarks; criminal law; Prevention; corporate governance, risk management and compliance. 


\section{SUMÁRIO}

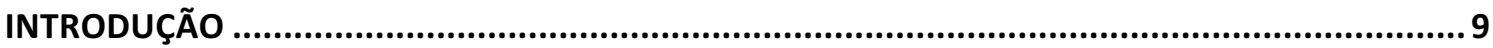

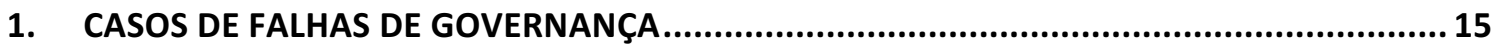

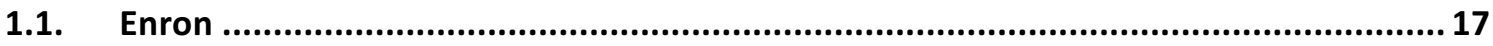

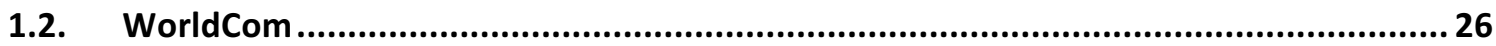

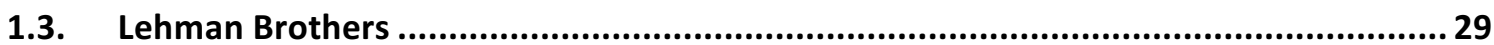

2. O DIREITO PENAL ECONÔMICO E A EXPANSÃO DO DIREITO PENAL NO ÂMBITO

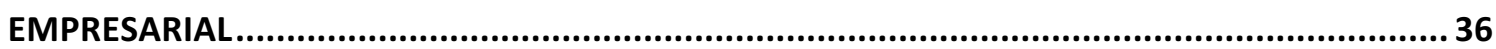

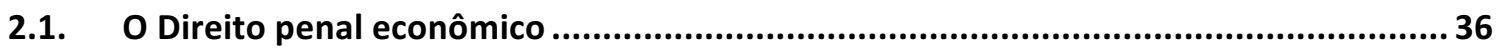

2.2. Possíveis implicações da expansão do direito penal econômico.................................. 39

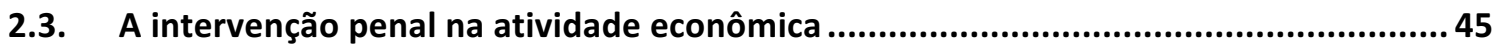

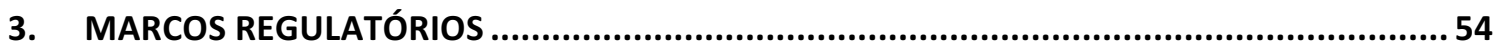

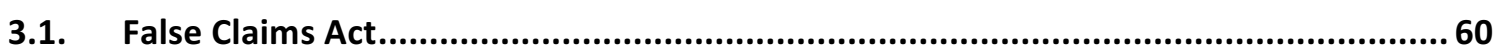

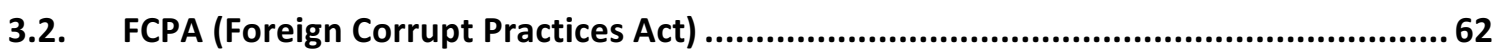

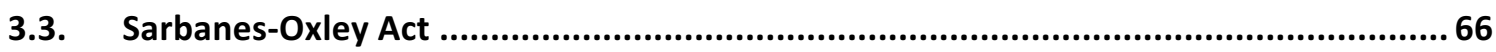

3.4. Dodd-Frank Wall Street Reform and Consumer Act ................................................... 73

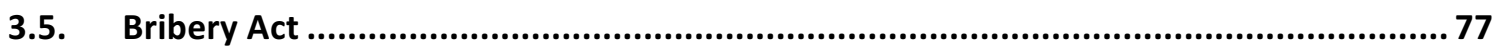

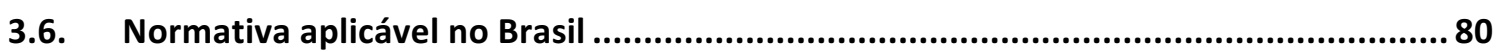

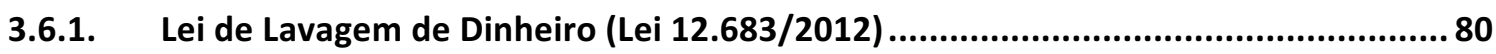

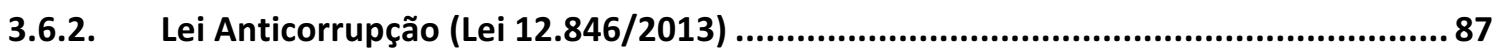

3.6.2.1. Decreto n. 60.106, de 29 de janeiro de 2014 ..................................................... 91

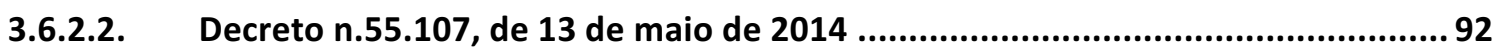

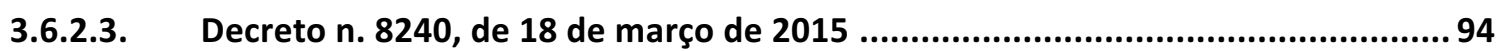

3.7. Diretrizes e Orientações da soft law e Convenções Internacionais ............................... 96

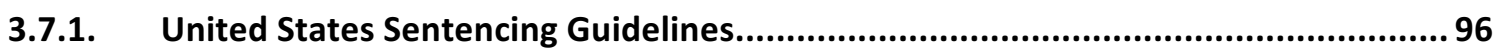

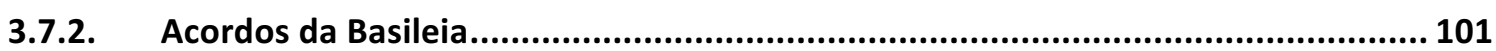

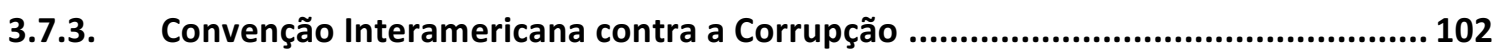

3.7.4. Convenção das Nações Unidas contra a Corrupção ............................................. 104

4. A PREVENÇÃO AOS CRIMES ECONÔMICOS DENTRO DAS EMPRESAS ............................ 108

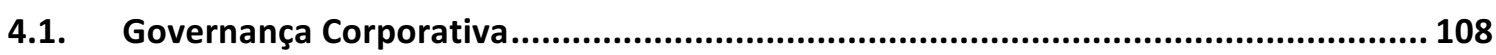

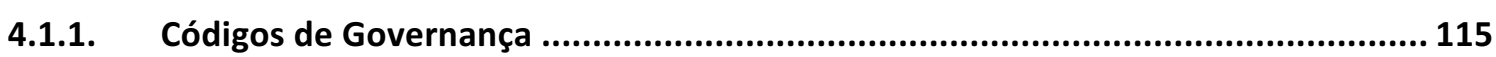

4.1.1.1. Código de Governança do IBGC (Instituto Brasileiro de Governança

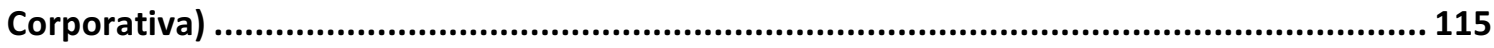

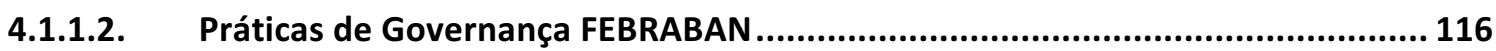

4.1.1.3. Níveis de governança corporativa e o novo mercado da Bolsa de Valores de São

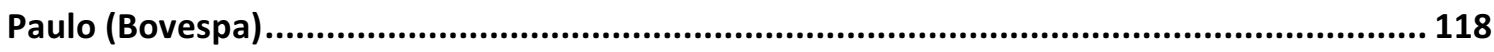

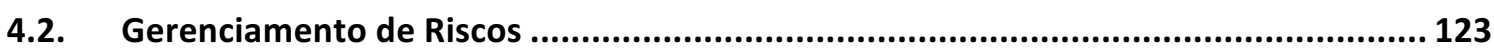

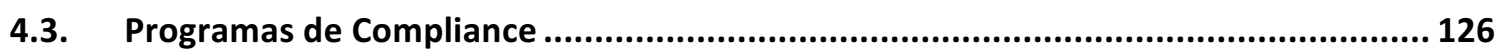

4.3.1. O compliance officer e o dever de vigilância............................................................ 143

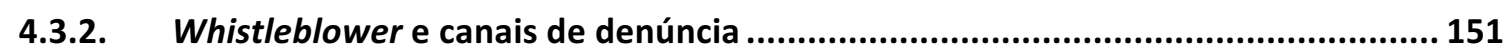

4.3.3. Responsabilidade penal empresarial pelo déficit de organização.......................... 153

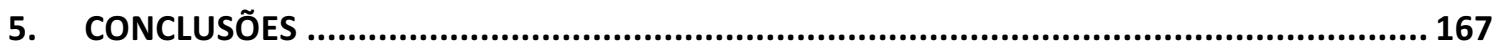

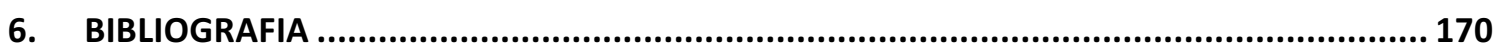




\section{A IMPORTÂNCIA DOS MARCOS REGULATÓRIOS NA PREVENÇÃO À CRIMINALIDADE ECONÔMICA}

\section{INTRODUÇÃO}

Em um momento em que poderosas empresas globalizadas assumem um significativo papel dentro de economias regionais e mundiais, os delitos econômicos e escândalos financeiros ganham uma nova importância em um direito penal caracterizado pela prevenção. Nesta "corporatização do mundo", a globalização transforma diversos atores econômicos e sociais em importantes reguladores, em âmbito regional, nacional e global, enfraquecendo os Estados Nacionais ao mesmo tempo em que interliga todos os mercados e elimina a ideia de espaços isolados ${ }^{2}$.

Diante da transformação e evolução das práticas capitalistas além das fronteiras, o centro do mundo deixa de voltar-se ao indivíduo, que passa a fazer parte de uma sociedade global $^{3}$. Nesta nova realidade, toda economia nacional integra um contexto global, com fronteiras dissolvidas e mercados mais rápidos. A atual organização destas corporações e a singularidade de suas atividades dificulta as ações de controle e prevenção por parte do Estado, cabendo ao direito um limitado controle sobre estes poderosos atores que se beneficiam da complexidade da lei, dos livros de contabilidade e das influentes tomadas de decisões ${ }^{4}$.

\footnotetext{
${ }^{1}$ BRAITHWAITE, John. Regulatory capitalism: how it works, ideas for making it work better. Massachusetts: Edward Elgar Publishing: 2008. p.29. Focando em soluções positivas que podem desempenhar um impacto positivo e efetivo na prevenção aos comportamentos desviantes, uma nova cultura ética é influenciada pelas corporações, em uma ampla rede de governança disposta a alinhar comportamentos éticos em processos decisórios. SAAD-DINIZ, Eduardo. Regulação privada: há ainda alternativas para a prevenção à corrupção e proteção de direitos humanos no âmbito corporativo? In: SAAD-DINIZ, Eduardo (org.); BRODOWSKI, Dominik (org.); SÁ, Ana Luiza de (org.). Regulação do abuso no âmbito corporativo: o papel do direito penal na crise financeira. São Paulo: Editora LiberArs, 2015. p.83-85.

${ }^{2} \mathrm{BECK}$, Ulrich. O que é globalização? Equívocos do globalismo, respostas à globalização. São Paulo: Editora Paz e Terra, 1999. p.29.

${ }^{3}$ IANNI, Octavio. Teorias da Globalização. Rio de Janeiro: Ed. Civilização Brasileira, 2004.p.13.

${ }^{4}$ BRAITHWAITE, John. The limits of economism in controlling harmful corporate conduct. Law and Society Review, 1981. p.482. Para Bruno Meyerhof Salama, na relação entre justiça e eficiência, o Direito deve ser visto como uma fonte de regulação de atividades que permita a concretização de políticas públicas, estimulando "as atividades produtivas, a resolução de conflitos, a democracia, a livre iniciativa, a redução da corrupção e burocracia, do desperdício e da pobreza". SALAMA, Bruno Meyerhof. Direito e Economia. In: José Rodrigo Rodriguez. (Org.). Fragmentos para um Dicionário Crítico de Direito e Desenvolvimento. 2ed.São Paulo: Saraiva, 2011, v. 1, p. 101-116.
} 
Com as novas tecnologias constantemente aperfeiçoadas e do fim das barreiras físicas, o Estado e as empresas estabelecem uma nova realidade, baseada na prevenção e sanção dos comportamentos delitivos danosos à empresa e ao seu entorno. Nas palavras de Ulrich Beck, em meio às complexidades do mercado mundial "formou-se uma nova economia virtual de correntes monetárias transnacionais cada vez menos vinculada a um substrato material e enredada em um jogo de informações e dados ${ }^{5 \%}$. Estes perigos da especulação estariam aquém do controle dos Estados Nacionais em um contexto em que estes novos riscos não se limitam mais ao espaço e ao tempo ${ }^{6}$.

Dotados de alta complexidade, os delitos econômicos não afetam somente a economia de um país determinado, mas podem alcançar transcendência internacional ${ }^{7}$, razão pela qual assistimos a um crescente fenômeno de expansão do direito penal sobre a atividade econômica e empresarial ${ }^{8}$. A lei penal passa a ser utilizada como mais um instituto capaz de propiciar segurança aos negócios ${ }^{9}$, sendo caracterizada por inconsistências, lacunas e uma regulação excessiva, o que, no entendimento de Roland Hefendehl são resultados inevitáveis de uma tentativa apressada de corrigir o mercado por meio do direito penal, por exemplo, com a pretensão de recuperar a credibilidade do mercado, abalado com as fraudes contábeis, falsificações e manipulações dos balanços contábeis $^{10}$. Uma visão errada também para Bernd Schünemann, que não vê como possível que maior no uso do direito penal pudesse modificar práticas e riscos consolidados. Para ele, esta saída seria o "produto de uma sutil política midiática praticada pelos responsáveis pela crise e pelos detentores do $\operatorname{poder}^{11}$ ".

A falsa percepção de que o direito penal econômico poderia resolver todos os problemas coloca em segundo plano a importância de práticas efetivas de prevenção, que

\footnotetext{
${ }^{5} \mathrm{BECK}$, Ulrich. O que é globalização? Equívocos do globalismo, respostas à globalização. São Paulo: Editora Paz e Terra, 1999. p.42.

${ }^{6}$ BECK, Ulrich. op.cit. p.83.

${ }^{7}$ BERRUEZO, Rafael. Derecho penal económico. In: BERRUEZO, Rafael et al. Derecho penal económico, Buenos Aires: Editorial B de f., 2010. p.13.

${ }^{8}$ RODRIGUEZ ESTEVEZ, Juan María. Legalidad y Eficiencia en Materia Penal Empresaria. In: BERRUEZO, Rafael et al. Derecho penal económico, Buenos Aires: Editorial B de f., 2010. p. Derecho penal económico, Buenos Aires: Editorial B de f., 2010. p.94.

${ }^{9}$ SILVEIRA, Renato de Mello Jorge; NETTO, Alamiro Velludo Salvador. Sarbanes-Oxley-act e os vícios do direito penal globalizado. Revista Ultima Ratio, Rio de Janeiro, v. 1, n. 0, 2006. p.207.

${ }^{10}$ HEFENDEHL, Roland. Enron, WorldCom and the consequences: business criminal law between doctrinal requirements and the hopes of crime policy. Buffalo Criminal Law Review. Vol.8, n.1. Abril, 2004. p.53-57.

${ }^{11}$ SCHÜNEMANN, Bernd. A chamada "crise financeira" - falha sistêmica ou criminalidade globalmente organizada? In: GRECO, Luís (Coord.); SCHÜNEMANN, Bernd. Estudos de direito penal, direito processual penal e filosofia do direito. São Paulo: Marcial Pons, 2013. p.186.
} 
demandam tempo e esforço não só dos dirigentes, mas das autoridades, dos acionistas e dos demais stakeholders ${ }^{12}$. John Braithwaite complementa que soluções econômicas podem colaborar com a aplicação da lei e facilitar inovações de prevenção e regulação, auxiliando as empresas a encontrarem o caminho mais barato para a minimização de danos, enquanto o Direito, especialmente o direito penal, deve assegurar que as garantias liberais não sejam flexibilizadas em nome da defesa da economia ${ }^{13}$. Neste sentido, os marcos regulatórios são extremamente importantes para trazer limites às atividades empresariais e, se necessário, às sanções aplicadas pelo Estado aos agentes que se desviem do papel que devem exercer no mercado.

Argumenta Braithwaite que we have regulatory capitalism because capitalism is out of control $^{14} \mathrm{e}$, diante disto, devemos analisar as empresas não só como reguladas pelo poder estatal, mas também reconhecer sua importância como reguladoras ${ }^{15}$, para aplicar da melhor forma a regulação, técnica e politicamente. O Estado passa a buscar uma nova alternativa de prevenção, agindo de forma conjunta com as empresas através de uma autorregulação regulada, que busca por meio da interpretação das leis adaptar medidas de prevenção e controle que tenham por objetivo beneficiar a todos os stakeholders, aqui compreendidos acionistas, funcionários, comunidade, fornecedores e Estado. Com o objetivo da diminuição dos riscos decorrentes de suas atividades, as empresas mostram-se cada vez mais dispostas a investir em medidas de compliance $^{16}$, governança e gerenciamento de seus riscos.

Nesta sociedade de risco globalizada ${ }^{17}$, o direito penal econômico deve analisar os riscos relacionados às atividades desenvolvidas e sua relação com as punições envolvidas $^{18}$, considerado que o excesso aqui, se extremamente severo, poderá ocasionar um aumento no risco de quebra das empresas, perdas para acionistas, credores,

\footnotetext{
${ }^{12}$ HEFENDEHL, Roland. op.cit. p.85.

${ }^{13}$ BRAITHWAITE, John. The limits of economism in controlling harmful corporate conduct. Law and Society Review, 1981. p.502.

${ }^{14}$ Tradução: "Possuímos o capitalismo regulatório porque o capitalismo está fora de controle".

${ }^{15}$ BRAITHWAITE, John. Regulatory capitalism: how it works, ideas for making it work better. Massachusetts: Edward Elgar Publishing: 2008. p.40.

${ }^{16}$ KUHLEN, Lothar. Cuestiones fundamentales de compliance y derecho penal. In: KUHLEN, Lothar (ed.). MONTIEL, Juan Pablo (ed.). ORTIZ DE URBINA GIMENO, Iñigo (ed.). Compliance y teoria del derecho penal. Madrid: Marcial Pons, 2013.p. 64.

${ }^{17}$ SILVEIRA, Renato de Mello Jorge. Direito penal econômico como direito penal de perigo. São Paulo: Revista dos Tribunais, 2006. p.159.

${ }^{18}$ COFFEE JR, John C. No soul to damn: No body to kick: na unscandalized inquiry into the problem of corporate punishment. Michigan Law Review. Vol. 79, No. 3 (Jan. 1981), p. 408.
} 
funcionários e consumidores, causando danos maiores e mais prejudiciais que o próprio crime praticado.

A influência da globalização na diminuição do papel do Estado por estruturas de governança $^{19}$ implica uma considerável diminuição da eficácia dos ordenamentos nacionais. Entretanto, conforme explica Adán Nieto Martín, esta realidade não significa a total ausência do Estado, mas a garantia de sua presença, de forma eficaz, mediante uma forma de controle social mais adequada que envolveria uma cooperação entre os poderes públicos, os sujeitos regulados e outros agentes sociais, como ONGs e sindicatos ${ }^{20}$. Para ele, a empresa somente poderia garantir que seus diretores e funcionários ajam de acordo com a lei, quando se esforçar para que estes assumam valores éticos compartilhados com o Estado $^{21}$.

Os mecanismos de prevenção à criminalidade empresarial foram redefinidos e uma nova cultura organizacional fortalecida com o objetivo de reduzir as assimetrias de informações e fomentar a transparência, reforçando, assim, a confiança no mercado e substituindo a mentalidade unicamente repressora ${ }^{22}$. Com estruturas de incentivo ao cumprimento de deveres, as empresas desenvolveram mecanismos de prevenção às infrações econômicas, como diretrizes de governança corporativas e regras mais precisas de atribuição de responsabilidade ${ }^{23}$.

No primeiro capítulo são analisados três casos de fraudes corporativas que afetaram todo o mercado financeiro internacional, evidenciando as falhas de governança, análise de riscos e compliance. Os casos Enron, WorldCom e Lehman Brothers representam diferentes momentos de crises que deram ênfase ao fortalecimento do marco regulatório norte-americano e à necessidade de uma maior regulação que pudesse evitar a repetição dos mesmos problemas e a perda de confiança nos negócios.

\footnotetext{
${ }^{19}$ BERCOVICI, Gilberto. A influência do poder econômico sobre o poder político. Boletim IBCCRIM, São Paulo, v. 23, n. 274, p.8-9, set. 2015.

${ }^{20}$ NIETO MARTÍN, Adán. Responsabilidad social, gobierno corporativo y autorregulación: sus influencias en el derecho penal de la empresa. Polít. crim., No 5, 2008, A3-5, p.03-04. Para o autor, estaríamos diante de uma aliança entre os agentes do capitalismo e o Estado, que resultaria no fenômeno do corporate governance, com aspectos de prevenção e sanções, por parte da própria empresa, de comportamentos delitivos. NIETO MARTÍN, Adán. El programa político-criminal del corporate goverment: derecho penal de la empresa y gobierno corporativo. Revista Aranzadi de derecho y proceso penal, Navarra, n. 11, 2004. p.260.

${ }^{21}$ NIETO MARTÍN, Adán. Responsabilidad social, gobierno corporativo y autorregulación: sus influencias en el derecho penal de la empresa. op.cit. p.06.

${ }^{22}$ SAAD-DINIZ, Eduardo. A criminalidade empresarial e a cultura de compliance. Revista Eletrônica de Direito Penal AIDP-GB, v. 2, 2014.p.112-113.

${ }^{23}$ SAAD-DINIZ, Eduardo. op.cit. p. 113.
} 
Diante de casos emblemáticos de fraudes econômicas, crescem os discursos de emergência e a proteção demandada ao direito penal. Neste contexto, o segundo capítulo é dedicado à explicação de características do chamado direito penal econômico, destacando a importância do respeito às garantias existentes no direito penal tradicional. Observamos que a criminalidade econômica apresenta práticas sofisticadas que se aproveitam da diminuição das fronteiras espaciais e temporárias, o que dificulta a função repressora dos Estados Nacionais. Com a integração dos mercados, como um dos resultados da globalização, a unificação de práticas e padrões exige uma expansão do direito penal, que reforçaria o poder punitivo, sem dar a devida atenção às práticas de prevenção que poderiam realizar mudanças estruturais mais eficientes.

O terceiro capítulo traz os marcos regulatórios americano, britânico e brasileiro que serão analisados de forma separada, mas evidenciando a influência exercida especialmente pela regulação dos EUA em políticas econômicas e punitivas de outros países. Partindo do False Claims Act teve por objetivo regulamentar as penalidades não só criminais, mas também cíveis para as práticas de falsidade nos balanços e divulgação de informações falsas. O FCPA (Foreign Corrupt Practices Act), promulgado após o escândalo do Watergate, que tinha por objetivo prevenir atos de corrupção realizados dentro e fora do território americano, a pesquisa avança para a Lei Sarbanes-Oxley, com suas mudanças na condução da governança corporativa e a necessidade de restaurar a confiança nos mercados e nas corporações. Seguindo, foi analisado ainda o Dodd-Frank Wall Street Reform and Consumer Act que buscou reformar a regulação financeira dos EUA, por meio de novos padrões de vigilância e supervisão, que visavam proteger especialmente os consumidores do mercado financeiro e uma adequada avaliação dos riscos existentes. De grande importância para as modernas práticas de governança corporativa, o Bribery Act trouxe novos procedimentos de prevenção às práticas de corrupção. Em relação à normativa aplicável no Brasil, a pesquisa focou na Lei de Lavagem de Dinheiro (Lei n 9.613/98 e Lei $n^{\circ} 12.683 / 12$ ), na Lei Anticorrupção (Lei no 12.846/13) e nos seus respectivos decretos regulamentadores (Decreto $n^{\circ}$ 60.106/2014, em âmbito estadual; o Decreto $n^{\circ} 55.107 / 2014$, em âmbito municipal e o Decreto $n^{\circ} 8240 / 2015$, em âmbito federal). Mostra-se necessária a análise também das diretrizes estabelecidas por organizações internacionais, como os parâmetros de punição avaliados pela United States Sentencing Guidelines, o gerenciamento dos riscos através dos Acordos da Basileia e as Convenções contra a Corrupção, da OCDE. 
Os marcos regulatórios serão analisados inseridos em um panorama de prevenção à criminalidade econômica, com foco nas práticas de governança corporativa, gerenciamento de riscos e programas de compliance, explicados no quarto e último capítulo. A mudança de mentalidade que podemos observar vem acompanhada de uma regulação e supervisão da cultura de cumprimento ao Direito, com o fim de respeitar o ordenamento jurídico e a integridade organizacional das empresas.

Neste sentido, as práticas de auditorias, internas e externas exigem das empresas que estabeleçam estruturas organizacionais que implementem em seu cotidiano práticas de prevenção fiscalizadas por um compliance officer, por meio de medidas de supervisão e controle dos riscos. Será função da empresa proporcionar as chamadas hotlines, com as quais os funcionários (whistleblowers) poderão denunciar práticas ilegais aos responsáveis, que deverão avaliar a informação e aplicar as medidas necessárias. Esta implementação de uma organização adequada fará da empresa uma "boa cidadã corporativa", regida pelas normas de direito, ou à sua responsabilização penal pelo déficit de organização.

O presente trabalho foi organizado com o objetivo de enfatizar as práticas de prevenção à criminalidade econômica por meio dos dispositivos presentes nos marcos regulatórios americano, britânico e brasileiro, além de considerar a importância de diretrizes estabelecidas por organizações internacionais. 


\section{CASOS DE FALHAS DE GOVERNANÇA}

Os casos a seguir analisados colocaram em evidência a existência de práticas corporativas fraudulentas de grandes e influentes empresas que afetaram a segurança do mercado internacional, em decorrência da complexidade dos esquemas realizados ${ }^{24}$. Enron, WorldCom e Lehman Brothers são todos exemplos de grande repercussão, apresentados como exemplos de fracassos empresariais relacionados a problemas de governança e sérios problemas financeiros, uma vez descoberto que seus dados contábeis haviam sido impulsionados artificialmente por fraudes ou manipulações ${ }^{25}$.

A escolha dos casos foi motivada pela repercussão causada e a latente necessidade de reformulação da regulação, de forma prudente, com o objetivo de trazer estabilidade ao mercado e a proteção aos consumidores ${ }^{26}$. A análise destes casos busca servir de aprendizado, rumo a um ambiente empresarial gerador de maior valor de longo prazo para toda a sociedade ${ }^{27}$.

Quando a bolha de 2008 estourou, "os serviços americanos eram dominados por cinco bancos de investimento independentes, quatro enormes conglomerados financeiros, três seguradoras e três agências de classificação ${ }^{28 \%,}$ o que evidenciava o perigo iminente de um colapso global. O estopim da crise foram os inúmeros empréstimos hipotecários e as especulações fundamentadas em títulos mal avaliados pelas agências de rating ${ }^{29}$. Após a exploração de títulos complexos e garantidos por hipotecas que nunca seriam pagas, percebeu-se a necessidade de reestruturação da ordem financeira mundial, como forma de

\footnotetext{
${ }^{24}$ ROYSEN, Joyce. Histórico da criminalidade econômica. Revista Brasileira de Ciências Criminais, São Paulo, v. 11, 42 Esp, jan./mar. 2003. p.196.

${ }^{25}$ CLARK, Robert Charles. Corporate Governance changes in the wake of the Sarbanes-Oxley Act: a morality tale for policymakers too. Harvard Law and Economics Discussion, n.525, 2005.p.01.

${ }^{26}$ MATTOS, Eduardo da Silva. O que a crise do subprime ensinou ao Direito? Tese (Doutorado em Direito Comercial) - Faculdade de Direito, Universidade de São Paulo, São Paulo, 2014. p.80.

${ }^{27}$ SILVEIRA, Alexandre Di Miceli da. Governança corporativa no Brasil e no mundo teoria e prática. Rio de Janeiro: Editora Campus, 2010. p. 346.

${ }^{28}$ FERGUNSON, Charles H. O sequestro da América: como as corporações financeiras corromperam os Estados Unidos. Rio de Janeiro: Jorge Zahar Editor Ltda, 2012.p. 240.

${ }^{29}$ SCHÜNEMANN, Bernd. A chamada "crise financeira" - falha sistêmica ou criminalidade globalmente organizada? In: GRECO, Luís (Coord.); SCHÜNEMANN, Bernd. Estudos de direito penal, direito processual penal e filosofia do direito. São Paulo: Marcial Pons, 2013. p.185.
} 
evitar que novas bolhas especulativas ${ }^{30}$ trouxessem prejuízos bilionários aos cofres públicos, desemprego e perda da confiança no sistema como um todo ${ }^{31}$.

O estudo de casos aborda questões sobre processos sociais em que precisamos interpretar os modos como lidamos com os problemas, explorá-los para esclarecer relações sociais, percepções, opiniões, atitudes e comportamentos em um determinado contexto. Além disso, nos permite uma análise do fenômeno e a intenção de combinar a pesquisa com a ação, com um olhar na realidade ${ }^{32}$. O interesse, voltado à compreensão de determinados processos sociais, ocorre diante de um determinado contexto, quando o objetivo é compreender uma situação com profundidade, enfatizando seu significado para os envolvidos ${ }^{33}$.

No método comparativo, o estudo das semelhanças e diferenças entre diversos grupos e sociedades, contribui para uma melhor compreensão do comportamento ${ }^{34}$, verificando-se similaridades e explicando divergências. A análise de um pequeno número de casos justifica-se pela observação da unidade complexa, analisando-se as relações e princípios entre as partes estudadas. De acordo com Della Porta ${ }^{35}$, uma das principais características dos estudos de casos orientados é a seleção daqueles que se diferenciem pouco um do outro, possibilitando uma apreciação de sua relevância para um conjunto específico de questões.

Casos de atos ilícitos e má administração nos últimos tempos mostraram a diferença entre o texto e o comprometimento ético firmado pelas empresas, a sua integridade e

\footnotetext{
${ }^{30}$ Os preços de um determinado mercado podem divergir de acordo com determinados fundamentos, até que um grande estouro da bolha os corrija, com drásticos efeitos sobre a economia. Podem ser explicadas como resultado de pouca fiscalização, de um comportamento de manada ou com a ocorrência de fraudes. RIBEIRO, Ivan César. Regulação financeira, poder no mercado e crise financeira. Tese (Doutorado em Direito Comercial) - Faculdade de Direito, Universidade de São Paulo, São Paulo, 2012. p.81.

${ }^{31}$ MATTOS, Eduardo da Silva. O que a crise do subprime ensinou ao Direito? Tese (Doutorado em Direito Comercial) - Faculdade de Direito, Universidade de São Paulo, São Paulo, 2014. p.29.

${ }^{32}$ SWANBORN, Peter. Case Study Research: what, why and when. London: SAGE Publications Inc, 2010.p. 41.

${ }^{33}$ GODOI, Christiane Kleinübing (org). BANDEIRA-DE-MELLO, Rodrigo (org). SILVA, Anielson Barbosa da (org). op.cit. p. 119.

${ }^{34}$ MARCONI, Marina de Andrade. LAKATOS, Eva Maria. Fundamentos de metodologia científica. 7.ed. São Paulo: Atlas, 2010. p. 107.

${ }^{35}$ DELLA PORTA, Donatella. “Comparative Analysis: Case-oriented versus Variable-oriented research”. In Donatella Della Porta and Michael Keating (ed.), Approaches and methodologies in the social sciences: a pluralist perspective”. Cambridge: Cambridge University Press, 2008.
} 
práticas de compliance ${ }^{36}$. Más práticas de governança podem acarretar séria destruição de valor aos investidores e demais stakeholders e Alexandre di Miceli da Silveira entende ser mais fácil identificar o real valor da boa governança a partir de exemplos negativos do que casos de sucesso $^{37}$. Desta forma, os seguintes casos servem de panorama para contextualizar as falhas observadas e evidenciar a importância dos marcos regulatórios como forma de reorganizar o sistema e evitar novas graves crises.

\subsection{Enron}

Durante a década de 90, evitar regulações era uma excelente forma de ganhar dinheiro. O desastre da Enron, uma empresa com grandes inovações, revelou a fragilidade do seu sistema de governança corporativa ${ }^{38}$ e a ficção contábil aplicada em seus balanços ${ }^{39}$.

A empresa, reconhecida como a sétima maior empresa em receita nos EUA e empregando 25.000 pessoas ao redor do mundo, era considerada uma das mais admiradas companhias norte-americanas. Estudos acadêmicos demonstravam a transformação de uma empresa conservadora em uma companhia de energia internacionalmente forte ${ }^{40}$. A velocidade do colapso surpreendeu a muitos que até então não haviam recebido nenhum sinal das agências de avaliação de que haveria algum risco de crédito e que acompanhavam os analistas financeiros classificarem a empresa como uma ação de compra ${ }^{41}$.

Ao viajar de estado em estado pressionando reguladores, os executivos da Enron buscavam trazer ao mercado os "benefícios" da escolha e liberdade. Corromperam políticos a ponto de existir um "Ponto Enron" na legislação, que permitia uma completa exclusão da necessidade de divulgação para empresas relacionadas ao comércio de

\footnotetext{
${ }^{36}$ LAUFER, William S. Where is the moral indignation over corporate crime? In: BRODOWSKI, Dominik; DE LA PARRA, Manuel Espinoza de los Monteros; TIEDEMANN, Klaus (ed.). Regulating corporate criminal liability. Heidelberg: Springer, 2014.p.27.

${ }^{37}$ SILVEIRA, Alexandre Di Miceli da. Governança corporativa no Brasil e no mundo teoria e prática. Rio de Janeiro: Editora Campus, 2010. p. 346.

${ }^{38}$ COFFEE JR, John C. Understanding Enron: It's about the gatekeepers, stupid. 30 de julho de 2002. Columbia Law \& Economics Working Paper n.207. p.02. A Enron foi considerada a empresa mais inovadora por 05 anos consecutivos, especialmente enquanto suas ações valiam mais de noventa dólares. BRATTON, William W. Enron and the dark side of shareholder value. Tulane Law Review, n.76, 2002.p.1276.

${ }^{39}$ BRAITHWAITE, John. Regulatory capitalism: how it works, ideas for making it work better. Massachusetts: Edward Elgar Publishing: 2008. p.38.

${ }^{40}$ HAMILTON, Stewart. FRANCIS, Inna. Enron Collapse. Harvard Business Review. Maio, 2003. p.01.

${ }^{41}$ HAMILTON, Stewart. MICKLETHWAIT, Alicia. Greed and corporate failure: the lessons from recent disasters. New York: Palgrave Macmillan, 2006. p.34.
} 
eletricidade $^{42}$. Entretanto, o livre mercado só podia ser aproveitado pela própria Enron, sendo um espaço controlado e adquirido por uma única empresa ${ }^{43}$. Aproveitando a desregulamentação da produção de energia, das telecomunicações e dos serviços financeiros, a empresa que antes focava em distribuição de energia, expandiu suas atividades para "o comércio de energia, comércio de banda larga e de derivativos ${ }^{44, "}$

O aumento na desregulamentação da energia, no final dos anos 70 modificou a forma como a energia era produzida e comercializada nos EUA e permitiu a criação do maior sistema de tubulação de gás natural possuído por uma única companhia (37 mil milhas da fronteira do Canadá até a fronteira com a Flórida) ${ }^{45}$. Kenneth Lay, um economista especializado em energia, tornou-se presidente e CEO da Enron após a fusão das empresas Houston Natural Gas e InterNorth. Em 1985, a Enron abriu um escritório em Valhalla, Nova York, para transacionar óleo e produtos derivados do petróleo. No ano de 1989, Lay contratou Jeffrey Skilling para aconselhá-lo em como conseguir vantagens com a desregulamentação do mercado de gás a partir da criação de mecanismos que providenciariam financiamentos para menores produtores de gás, uma fonte segura e confiável $^{46}$. Andrew Fastow, com experiência em securitização e financiamentos estruturados, em 1990, foi contratado para desenvolver os financiamentos da empresa e obter e administrar as dívidas e o capital disponível ${ }^{47}$.

O empenho em manter os ganhos e os preços elevados das ações levou a um uso extensivo de políticas agressivas de contabilidade, como Entidades com fins específicos ("Special Purpose Entities" - SPE). Estas empresas tinham por fim manipular os dados contábeis para que a Enron pudesse fingir ter saúde financeira que lhe permitiria o acesso a crédito $^{48}$. O executivo Michael Kooper, executivo que trabalhou na empresa de 1994 a 2001, narrou que foram realizados "diversos acordos por meio das SPEs, empresas formadas a partir do capital da Enron que, devidamente manipulado, aparecia como

\footnotetext{
${ }^{42}$ BRATTON, William W. Enron and the dark side of shareholder value. Tulane Law Review, n.76, 2002.p.1280.

${ }^{43}$ BRATTON, William W. op.cit.p.1299.

${ }^{44}$ FERGUNSON, Charles H. O sequestro da América: como as corporações financeiras corromperam os Estados Unidos. Rio de Janeiro: Jorge Zahar Editor Ltda, 2012.p.177.

${ }^{45}$ HAMILTON, Stewart. FRANCIS, Inna. op.cit. p.02.

${ }^{46}$ HAMILTON, Stewart. FRANCIS, Inna. op.cit. p.02.

${ }^{47}$ HAMILTON, Stewart. FRANCIS, Inna. op.cit. p.04.

${ }^{48}$ BORGERTH, Vania Maria da Costa. SOX: entendendo a Lei Sarbanes-Oxley - um caminho para a informação transparente. São Paulo: Cengage Learning, 2008.p.02.
} 
contribuição financeira de investidores independentes ${ }^{49}$ ". Também foram desenvolvidos pagamentos de produção (VPP - volumetric production payment) com os quais a Enron fornecia liquidez a fornecedores de gás de longo prazo, com o pagamento assegurado no próprio gás e não nos ativos do produtor ${ }^{50}$.

O uso de instrumentos financeiros expôs a empresa a riscos de crédito excessivos, evidenciando a imprudência de suas políticas de avaliação de negócios ${ }^{51}$. Os contratos de longo prazo de comércio de eletricidade falharam ao esperar ganhos que apenas viriam no futuro, ao invés de calcular o reconhecimento de custos e receitas em um registro contábil convencional $^{52}$. A Enron também cometeu graves fraudes financeiras para criar lucros artificiais e esconder dívidas e perdas: com o auxílio de bancos como o JP Morgan Chase, criou receitas de vendas falsas de gás através de entidades fictícias, gerando um golpe de 2,2 bilhões de dólares em lucros associados ${ }^{53}$. Ocorre que, com exceção de contratos fraudulentos em que a empresa simulava empréstimos, "nenhuma das outras transações era efetivamente ilegal ${ }^{54,}$.

Instalações de gás não eram favorecidas diante das preocupações em relação à confiabilidade nos abastecimentos e na estabilidade do preço do gás. Então, a Enron precisava encontrar novos consumidores industriais para o produto e a inovação apareceu, em janeiro de 1992, com um acordo de vinte anos com a empresa Sithe Energies para o fornecimento de gás natural suficiente para uma central de produção de 1000 megawatts de eletricidade construída pela Sithe em Nova York ${ }^{55}$.

Foi utilizada uma técnica denominada de gas bunk, um mecanismo com o qual fornecia financiamento para produtores menores, possibilitando que estes pudessem investir mais em exploração e desenvolvimento e, ao mesmo tempo, proporcionavam à

\footnotetext{
${ }^{49}$ ROYSEN, Joyce. Histórico da criminalidade econômica. Revista Brasileira de Ciências Criminais, São Paulo, v. 11, 42 Esp, jan./mar. 2003. p.198.

${ }^{50}$ HAMILTON, Stewart. MICKLETHWAIT, Alicia. Greed and corporate failure: the lessons from recent disasters. New York: Palgrave Macmillan, 2006. p.38.

${ }^{51}$ BRATTON, William W. Enron and the dark side of shareholder value. Tulane Law Review, n.76, 2002.p.1302.

${ }^{52}$ BRATTON, William W. op.cit.p.1304.

${ }^{53}$ FERGUNSON, Charles H. O sequestro da América: como as corporações financeiras corromperam os Estados Unidos. Rio de Janeiro: Jorge Zahar Editor Ltda, 2012.p.177-178.

${ }^{54}$ BORGERTH, Vania Maria da Costa. SOX: entendendo a Lei Sarbanes-Oxley - um caminho para a informação transparente. São Paulo: Cengage Learning, 2008.p.03.

${ }^{55}$ HAMILTON, Stewart. FRANCIS, Inna. op.cit. p.03.
} 
Enron fontes confiáveis de gás natural ${ }^{56}$. A empresa comprou centrais de energia no Brasil e na Bolívia e participações em uma rede de oleodutos na Argentina com quatro mil milhas que entregaria dois terços do gás no país, assim como construiu uma central elétrica na Inglaterra. Até 1994, operava centrais de energia e projetos de tubulação em mais de 15 países $^{57}$. A indústria estava verticalmente integrada, desde as fontes de gás natural ou a geração de eletricidade, até seu transporte, distribuição e venda no mercado.

A Enron abraçou a visão de livre mercado de Lay e o ambiente era de grande pressão para que as metas fossem alcançadas. Para a empresa, não importava perder dinheiro nos anos 1-5, desde que o investimento fosse recuperado nos anos 6-10 Conhecida por ter uma estrutura reformulada, que evitava burocracias, a Enron permitia um alinhamento entre os interesses dos funcionários e da empresa, o que possibilitava o engajamento em comportamentos oportunistas ${ }^{59}$. Os times das diversas áreas estabeleciam seus objetivos e implementavam projetos que lhes permitiriam atingir os resultados esperados, sempre trabalhando sob um incrível risco em busca de resultados favoráveis no curto prazo $^{60}$.

Enquanto aparentava ser uma empresa de reputação bem sedimentada em valores éticos, a companhia, ao mesmo tempo, proporcionava recompensas para aqueles funcionários que atingissem as metas estabelecidas, passando a mensagem implícita de que deveriam competir agressivamente para chegar nestas metas, ainda que para isso fossem necessárias condutas antiéticas ${ }^{61}$. A empresa falhou em encontrar fontes significativas que pudessem manter suas contas estáveis ${ }^{62}$. Enquanto considera-se que o valor da empresa resulta da sua habilidade em ganhar dinheiro com o tempo, a Enron perdeu toda sua credibilidade ao encobrir suas perdas com contratos fraudulentos que realizava com si mesma $^{63}$.

\footnotetext{
${ }^{56}$ HAMILTON, Stewart. MICKLETHWAIT, Alicia. Greed and corporate failure: the lessons from recent disasters. New York: Palgrave Macmillan, 2006. p.35.

${ }^{57}$ HAMILTON, Stewart. FRANCIS, Inna. Enron Collapse. Harvard Business Review. Maio, 2003. p.03.

${ }^{58}$ HAMILTON, Stewart. MICKLETHWAIT, Alicia. op.cit. p.40.

${ }^{59}$ ROSEN, Robert Eli. Risk Management and Corporate Governance: The Case of Enron. 35 Connecticut Law Ver. 2003. p.1162.

${ }^{60}$ BRATTON, William W. Enron and the dark side of shareholder value. Tulane Law Review, n.76, 2002.p.1292.

${ }^{61}$ BLAIR, Margaret. Post-Enron reflections on comparative corporative governance. Georgetown Law and Economics, 2002. p.10.

${ }^{62}$ BRATTON, William W. op.cit. p. 1281.

${ }^{63}$ BRATTON, William W. op.cit. p.1320.
} 
Após diversas manobras contáveis ${ }^{64}$, em 2001, a empresa Enron foi forçada a declarar falência e revelar que possuía bilhões de dólares em dívidas extrapatrimoniais em empresas com propósitos especiais, fazendo com que suas ações despencassem de US\$90 para US $\$ 0,50^{65}$. O principal propósito destas práticas consistia mais em evitar relatar suas perdas, especialmente encargos contábeis que não interferiam no fluxo de caixa, do que esconder dívidas ${ }^{66}$, desta forma, seu preço era mantido por operadores externos que possuíam informações limitadas sobre a companhia ${ }^{67}$.

Todos os altos funcionários eram bem remunerados e aproveitavam vantajosos benefícios, de forma que a culpa pelo colapso não pode ser atribuída a um único indivíduo. A empresa entrou em áreas de grande risco sem domínio suficiente ou diligência devida. Os diretores, com suas responsabilidades legais de tomar as melhores decisões para a empresa, assim como distribuir os rendimentos e ativos de forma cuidadosa e baseada na lealdade, o que, teoricamente, faria com que eles não agissem de forma egoísta ao expor a empresa a riscos desnecessários. Entretanto, o que pode ser visto na condução da Enron é que os seus administradores não foram confiáveis ${ }^{68}$.

O conselho falhou diversas vezes por não solicitar maiores informações e provas para que pudesse entender perfeitamente os riscos existentes nas operações ${ }^{69}$. Algumas vezes o Conselho da Enron nem sequer teve conhecimento de importantes decisões tomadas $^{70}$, em outras escolheu ignorar os problemas, em outras agiu de forma inoperante autorizando, com conhecimento, políticas de alto risco, não respeitando o código de condutas e falhando ao assegurar controles suficientes que garantissem os interesses da

\footnotetext{
${ }^{64}$ ROYSEN, Joyce. Histórico da criminalidade econômica. Revista Brasileira de Ciências Criminais, São Paulo, v. 11, 42 Esp, jan./mar. 2003. p.196.

${ }^{65}$ SCARROW, Devin. Understanding the Sarbanes-Oxley Act and its impact. Harvard Business Review. Setembro, 2009. p.01.

${ }^{66}$ MORGENSON, Gretchen. The Markets: Stocks \& Bonds; Worries of more Enrons to come give stock prices a pounding. The New York Times, 30 de janeiro de 2002.

${ }^{67}$ BRATTON, William W. Enron and the dark side of shareholder value. Tulane Law Review, n.76, 2002.p.1322.

${ }^{68}$ BLAIR, Margaret. Post-Enron reflections on comparative corporative governance. Georgetown Law and Economics, 2002. p.07.

${ }^{69}$ ROSEN, Robert Eli. Risk Management and Corporate Governance: The Case of Enron. 35 Connecticut Law Ver. 2003. p.1158.

${ }^{70}$ BORGERTH, Vania Maria da Costa. SOX: entendendo a Lei Sarbanes-Oxley - um caminho para a informação transparente. São Paulo: Cengage Learning, 2008.p.03.
} 
Enron, especialmente nos contratos com as entidades especiais ${ }^{71}$, e desrespeitando as obrigações que tinha com os acionistas ${ }^{72}$.

Antes da falência, a Enron era admirada por suas sofisticadas ferramentas de gerenciamento de riscos ${ }^{73}$. Conforme mencionado anteriormente, cabia aos diversos times a implementação de seus projetos, e muitas vezes, negócios com poucas perspectivas de lucros e projeções de altas perdas eram aprovados. Neste contexto, os funcionários, preocupados com vultuosos bônus, conseguiam captar os recursos necessários de outros grupos para investir em suas ideias, como o Enron Online, por exemplo, que mobilizou um investimento de quinze milhões de dólares e cerca de quatrocentos funcionários antes mesmo da aprovação ${ }^{74}$.

Outra grave violação das obrigações com os shareholders foi a quebra do dever de fornecer uma divulgação de informações real e completa. O uso de uma prática conhecida como "muralha da China", cujo objetivo é evitar que banqueiros de investimentos usem informações confidenciais sobre clientes para investir nestas ações. No caso da Enron, aos potenciais clientes eram divulgadas, em detalhes, transações e ativos não contabilizados, porém seus acionistas não tinham conhecimento destas informações. Os bancos, sob a justificativa de que estariam limitados por conflitos entre seus papéis de credores e seguradores, ao menos poderiam ter alertado o mercado ao retirar as recomendações das ações da Enron ${ }^{75}$. Em relação aos funcionários, “o Fundo de Pensão da empresa foi à bancarrota, deixando desamparados os milhares de funcionários honestos e dedicados ${ }^{76,}$.

O evento abalou a confiança dos acionistas em todo o país, fazendo com que o caso Enron fornecesse amplas evidências de uma falha sistemática de governança e demonstrasse a necessidade por maior transparência, produzindo um importante paradigma cultural que levou a mudanças na forma como os negócios seriam feitos nos $\mathrm{EUA}^{77}$. As falhas de governança custaram aos seus stakeholders cerca de US\$700 milhões em lucros

\footnotetext{
${ }^{71}$ HAMILTON, Stewart. MICKLETHWAIT, Alicia. Greed and corporate failure: the lessons from recent disasters. New York: Palgrave Macmillan, 2006. p.53.

${ }^{72}$ ROSEN, Robert Eli. Risk Management and Corporate Governance: The Case of Enron. 35 Connecticut Law Ver. 2003. p.1157.

${ }^{73}$ ROSEN, Robert Eli. op.cit. p. 1165.

${ }^{74}$ ROSEN, Robert Eli. op.cit. p.1166-1167.

${ }^{75}$ HENRIQUES, Diana B.; EICHENWALD, Kurt. A Fog over Enron, and the legal landscape. The New York Times, 27 de janeiro de 2002.

${ }^{76}$ BORGERTH, Vania Maria da Costa. SOX: entendendo a Lei Sarbanes-Oxley - um caminho para a informação transparente. São Paulo: Cengage Learning, 2008.p.04.

${ }^{77}$ WEISSMANN, Andrew. Perspectives on Compliance Programs: The Enron Verdict. p.01.
} 
líquidos, US $\$ 1.2$ bilhões de retornos aos acionistas (shareholders'equity) desapareceram e US\$ 4 bilhões em obrigações escondidas ${ }^{78}$. A confiança no mercado depende de algumas convicções como a sinceridade dos dirigentes, a possibilidade de auditores julgarem as posições financeiras e dos analistas de investimento e agências de rating poderem analisar quão promissora as empresas são ${ }^{79}$. No caso da Enron, todas estas crenças foram abaladas, especialmente a crescente desconfiança com os relatórios financeiros divulgados pelas empresas, trazendo maior insegurança ao ambiente de negócios ${ }^{80}$.

Para John Coffee Jr, as irregularidades financeiras ocorridas foram uma consequência lógica e natural de tendências que se desenvolviam a algum tempo, considerando que, em estados de euforia do mercado, os investidores tendem a ser mais céticos e nota-se uma mudança nos comportamentos dos gatekeepers, administradores e $\operatorname{acionistas}^{81}$. Ainda que outros casos já tivessem sido descobertos, nenhum gerara semelhante distúrbio no mercado ${ }^{82}$. Até outubro de 2001, 16 de cada 17 analistas recomendavam a compra das ações da empresa até que o momento da declaração da falência ${ }^{83}$.

O time financeiro da Enron contava com líderes vistos como inovadores que utilizavam os derivativos, desenvolvidos para isentar seus operadores do controle regulatório $^{84}$, e outras complexas operações financeiras como solução dos problemas corporativos $^{85}$. Enquanto isso, o departamento tributário preocupava-se com inovações que agregassem valor à companhia, especialmente através de paraísos fiscais ${ }^{86}$.

A empresa de auditorias, Arthur Andersen, envolveu-se em uma série de fraudes que culminaram em sua desastrosa associação com a Enron $^{87}$, evidenciando a omissão dos

\footnotetext{
${ }^{78}$ BRATTON, William W. Enron and the dark side of shareholder value. Tulane Law Review, n.76, 2002.p.1282.

${ }^{79}$ MORGENSON, Gretchen. The Markets: Stocks \& Bonds; Worries of more Enrons to come give stock prices a pounding. The New York Times, 30 de janeiro de 2002.

${ }^{80}$ BRATTON, William W. op.cit. p. 1277.

${ }^{81}$ COFFEE JR, John C. What caused Enron? 20 de janeiro de 2003. Columbia Law \& Economics Working Paper n. 214, p. 02-05.

${ }^{82}$ COFFEE JR, John C. Understanding Enron: It's about the gatekeepers, stupid. 30 de julho de 2002. Columbia Law \& Economics Working Paper n.207. p.04.

${ }^{83}$ COFFEE JR, John C. Understanding Enron: It's about the gatekeepers, stupid. p.09.

${ }^{84}$ BRAITHWAITE, John. Regulatory capitalism: how it works, ideas for making it work better. Massachusetts: Edward Elgar Publishing: 2008. p.40.

${ }^{85}$ ROSEN, Robert Eli. Risk Management and Corporate Governance: The Case of Enron. 35 Connecticut Law Ver. 2003. p.1168.

${ }^{86}$ ROSEN, Robert Eli. Risk op.cit. p.1168.

${ }^{87}$ COFFEE JR, John C. op.cit. p.07.
} 
auditores externos nas demonstrações contábeis da companhia ${ }^{88}$. A auditora trabalhava com cerca de 2300 clientes, o que, aparentemente, poderia ter funcionado como um desincentivo para assumir riscos que pudessem prejudicar sua reputação ${ }^{89}$. Entretanto, sua credibilidade foi severamente comprometida, primeiro por ter autorizado que sua independência, como uma firma, fosse fragilizada, segundo, por apresentar uma grande falha de governança interna no controle de $\operatorname{problemas}^{90} \mathrm{e}$, por fim, por ter destruído qualquer documentação que pudesse evidenciar a contabilidade fraudulenta da Enron ou sua própria quebra de dever ${ }^{91}$.

Há indícios suficientes para afirmar que a Arthur Andersen cometeu negligência profissional na prestação de serviços realizada à empresa Enron. A pressão para gerar receitas era intensa e o conflito de interesses evidente, uma vez que funcionários da auditora trabalhavam nos escritórios da Enron $^{92}$. Melhores regras de transparência poderiam ter alertado os investidores dos conflitos existentes entre a empresa Enron e os membros do comitê de auditoria. A falha da auditoria em exigir explicações sólidas sobre as reais condições financeiras da Enron indica que as remunerações trouxeram junto o silêncio e não as obrigações com os investidores ${ }^{93}$.

Para John Coffee $\mathrm{Jr}^{94}$, duas versões poderiam explicar a falha dos gatekeepers no caso Enron: a "história da dissuasão geral" e a "história da bolha". A primeira foca na diminuição do risco de responsabilidade e do cumprimento de medidas preventivas por parte das empresas. As empresas de auditoria cobravam, aproximadamente, o triplo de grandes empresas, o que se mostrou um negócio vantajoso. Da mesma forma seria vantajosa a manutenção do status quo da empresa contratante por parte da auditora. Por outro lado, demitir uma empresa de auditoria poderia ser muito trabalhoso, sendo mais fácil lidar com uma empresa de consultoria. A segunda versão poderia ser uma consequência de uma clássica "bolha" que produziu uma grande euforia no mercado nos

\footnotetext{
${ }^{88}$ ROYSEN, Joyce. Histórico da criminalidade econômica. Revista Brasileira de Ciências Criminais, São Paulo, v. 11, 42 Esp, jan./mar. 2003. p.198.

${ }^{89}$ COFFEE JR, John C. What caused Enron? 20 de janeiro de 2003. Columbia Law \& Economics Working Paper n. 214. p.15.

${ }^{90}$ GORDON, Jeffrey N. What Enron means for the management and control of the modern business corporations: some initial reflections. University of Chicago Law Review, Summer 2002. p.06.

${ }^{91}$ BORGERTH, Vania Maria da Costa. SOX: entendendo a Lei Sarbanes-Oxley - um caminho para a informação transparente. São Paulo: Cengage Learning, 2008.p.06.

${ }^{92}$ HAMILTON, Stewart. MICKLETHWAIT, Alicia. Greed and corporate failure: the lessons from recent disasters. New York: Palgrave Macmillan, 2006. p.54.

${ }^{93}$ LAVELLE, Louis. How governance rules failed at Enron. Bloomberg Business, 20 de janeiro de 2002.

${ }^{94}$ COFFEE JR, John C. Understanding Enron: It's about the gatekeepers, stupid. p.11-23.
} 
anos 90, tornando os gatekeepers irrelevantes. Somente quando estouram as "bolhas", os gatekeepers retomam sua importância e os investidores voltam a buscar garantias que apenas os intermediários podem fornecer. De acordo com Coffee $\mathrm{Jr}$, as "bolhas" não são apenas momentos irracionais de especulação, mas são o resultado de expectativas de que estes momentos de retornos extraordinários vão persistir ${ }^{95}$. Desta forma, ao acreditarem que os lucros excessivos serão duradouros, não há mais necessidade para os serviços dos gatekeepers.

Os analistas financeiros também são considerados intermediários importantes e até 2000, as ações da Enron valiam cerca de 70 vezes os seus ganhos e cerca de seis vezes o seu valor de balanço e nenhum de seus vigilantes, aqui entendidos os analistas, auditores, agência de rating, percebeu o que aconteceria até os últimos momentos ${ }^{96}$. O problema dos momentos de maior euforia do mercado é que aqueles que agirem de forma cautelosa terão seu desempenho superado por aqueles mais imprudentes.

O caso Enron demonstrou um grave problema de compliance e também um fracasso empresarial, considerando suas estratégias de aumentar a aquisição de energias altamente alavancadas e investir mercados de produtos financeiros, o que ampliou a sua exposição financeira a riscos ${ }^{97}$. Seu sistema de governança assumiu riscos significativos em nome de incentivos à inovação, economizando em custos de execução ${ }^{98}$. Suas ações mostraram o pior lado da busca pelo shareholder value, enquanto suas ações valorizavam, especialmente por análises que buscavam não se comprometer ao ir contra uma das principais empresas norte-americanas ${ }^{99}$.

Além da falha empresarial, evidenciou os defeitos do sistema regulatório norteamericano, visto como exemplo para o restante do mundo. Os procedimentos e regulamentos mobiliários não garantiram transparência nem a proteção dos acionistas minoritários ${ }^{100}$. Evidenciou-se que incentivos financeiros e exigências regulatórias não são suficientes para assegurar que as atividades empresariais sejam conduzidas de forma

\footnotetext{
${ }^{95}$ COFFEE JR, John C. What caused Enron? 20 de janeiro de 2003. Columbia Law \& Economics Working Paper n. 214. p.33.

${ }^{96}$ COFFEE JR, John C. op.cit. p.24.

${ }^{97}$ ROSEN, Robert Eli. Risk Management and Corporate Governance: The Case of Enron. 35 Connecticut Law Ver. 2003. p.1171.

${ }^{98}$ BRATTON, William W. Enron and the dark side of shareholder value. Tulane Law Review, n.76, 2002.p.1283.

${ }^{99}$ BRATTON, William W. op.cit. p.1285.

${ }^{100}$ BLAIR, Margaret. Post-Enron reflections on comparative corporative governance. Georgetown Law and Economics, 2002. p.03.
} 
adequada, sendo necessária uma cooperação voluntária das empresas e confiança entre os participantes do mercado ${ }^{101}$.

Resultado de uma desregulamentação excessiva, a Enron manipulou o sistema enquanto conseguiu esconder seus problemas em balanços contábeis falsos e em uma conduta de tomada de riscos excessivas vista como uma agressividade a ser copiada. Seus diversos times buscando objetivos distintos prejudicaram um controle efetivo das atividades desenvolvidas pela empresa. A quebra da sétima maior receita dos EUA mostra a importância das práticas de prevenção e da importância da governança integrada a todo sistema (análise de riscos, transparência, tomada de decisões, controle interno, organização), empresas, auditoras, credores e investidores.

\subsection{WorldCom}

Em junho de 2002, a segunda maior empresa de telecomunicações anunciou que havia exagerado os ganhos de 2001 em mais de US\$3 bilhões, deixando atônitos os analistas financeiros ${ }^{102}$. Com um início humilde no estado do Mississipi chegou a ser uma das principais companhias dos EUA. Entre 1991 e 1997, a WorldCom gastou cerca de $\$ 60$ bilhões de dólares em aquisições, e seu crescimento chamou a atenção dos analistas e investidores de Wall Street ${ }^{103}$.

Entretanto, a empresa falhou em duas situações com suas bilionárias aquisições: não conseguiu integrar as novas companhias com as organizações antigas e não soube trabalhar com os aspectos financeiros destas fusões. $O$ talento que a empresa tinha para comprar competidores não era acompanhado pelo conhecimento de incorporá-los ${ }^{104}$.

A WorldCom que até 1999 era uma das empresas preferidas dos investidores por apresentar uma combinação de ativos, estratégias, administração e avaliações positivas dentro do setor global de telecomunicações ${ }^{105}$, admitiu ter classificado uma enorme quantia

\footnotetext{
${ }^{101}$ BLAIR, Margaret. Post-Enron reflections on comparative corporative governance. Georgetown Law and Economics, 2002. p.05.

${ }^{102}$ LYKE, Bob; JICKLING, Marlk. WorldCom: the accounting scandal. CRS Report for Congress. Agosto, 2002. p.01.

${ }^{103}$ MOBERG, Dennis; ROMAR, Edward. WorldCom Case Study. p. 02.

${ }^{104}$ MOBERG, Dennis; ROMAR, Edward. WorldCom Case Study. p. 03.

${ }^{105}$ HAMILTON, Stewart. MICKLETHWAIT, Alicia. Greed and corporate failure: the lessons from recent disasters. New York: Palgrave Macmillan, 2006. p.59.
} 
como investimentos de capital e não como despesas correntes, aumentando seu lucro líquido e seus ativos ${ }^{106}$. Houve, ainda, uma manipulação das linhas de custo, cujos valores eram lançados após o período correspondente e com nomes diferentes ${ }^{107}$. A cada trimestre “a empresa revisava seus números de forma a adequá-los às estimativas dos analistas independentes ${ }^{108}$,

O foco da WorldCom era gerar receitas com todas as operações que fossem realizadas. O chefe-executivo Ebbers adotou uma estratégia de mercado, quando administrava a WorldCom, que foi o crescimento através de aquisições de ações da empresa $^{109}$, institucionalizando a cultura do lucro acima de tudo, limitando as informações financeiras e delegando responsabilidades a gestores que agiam de forma antiética ${ }^{110}$.

O caso envolveu não apenas uma fraude contábil, mas decisões estratégicas deficitárias, falhas de avaliação, um CEO extremamente totalitário e centralizador, um Conselho passivo que aceitava todas as decisões de Ebbers, e inadequadas auditorias externa e interna ${ }^{111}$. A participação do CFO, Scott Sullivan, também facilitou que as acrobacias contábeis não fossem descobertas imediatamente ${ }^{112}$. De modelo da economia, a WorldCom foi declarada o maior caso de falência da história americana ${ }^{113}$. As ações da WorldCom baixaram de US\$64 para menos de US\$2, fazendo com que muitos funcionários perdessem dinheiro com seus planos de aposentadorias vinculados às ações.

Ebbers chegou a afirmar que estabelecer um código de condutas seria uma enorme perda de tempo, razão pela qual o departamento de auditoria interna era inefetivo e perdeu claros sinais de problemas em suas avaliações ${ }^{114}$. A fraude na WorldCom não causou seu colapso, mas sim ocorreu como forma de maquiar as deficiências da gestão de Ebbers e foi

\footnotetext{
${ }^{106}$ LYKE, Bob; JICKLING, Marlk. op.cit. p.02. A Enron afirmou ter errado ao classificar como aplicações de capital cerca de 11 bilhões de dólares. BURNS, Arthur F.; EDWARDS, Franklin R. U.S. Corporate Governance: what went wrong and can it be fixed?. Chicago, 2003. p.07.

${ }^{107}$ HAMILTON, Stewart. MICKLETHWAIT, Alicia. Greed and corporate failure: the lessons from recent disasters. New York: Palgrave Macmillan, 2006. p.69.

${ }^{108}$ BORGERTH, Vania Maria da Costa. SOX: entendendo a Lei Sarbanes-Oxley - um caminho para a informação transparente. São Paulo: Cengage Learning, 2008.p.07.

${ }^{109}$ LAUFER, William S. Corporate Bodies and Guilty Minds: The failure of Corporate Criminal Liability. Chicago: University of Chicago Press, 2006. p.68.

${ }^{110}$ LAUFER, William S. op.cit. p.69.

${ }^{111}$ HAMILTON, Stewart. MICKLETHWAIT, Alicia. op.cit. p.59-60.

${ }^{112}$ HOMER, Julia; KATZ, David M. WorldCom whistleblower Cynthia Cooper. CFO, $1^{\circ}$ de fevereiro de 2008. Disponível em: <http://ww2.cfo.com/human-capital-careers/2008/02/worldcom-whistle-blowercynthia-cooper/>. Acesso em 30 de maio de 2016.

${ }^{113}$ MOBERG, Dennis; ROMAR, Edward. WorldCom Case Study. p. 01.

${ }^{114}$ HAMILTON, Stewart. MICKLETHWAIT, Alicia. op.cit. p.71.
} 
permitida diante do fracasso que eram os seus controles ${ }^{115}$. O catalizador para que a situação chamasse a atenção dos responsáveis foi a proibição, pelo governo norteamericano, da compra da empresa Sprint, pondo fim às inúmeras aquisições características da WorldCom ${ }^{116}$.

Ainda que com auditores internos e externos, levou-se mais de um ano para que a classificação incorreta fosse descoberta, uma vez que a revisão interna dos livros da companhia, somente foi feita a pedido do novo chefe executivo, John W. Sidgmore ${ }^{117}$. Controles fracos e a grande descentralização permitiram que os contadores apagassem e criassem números que só existiam nas previsões de Bernard J. Ebbers. Esta dispersão geográfica entre as sedes ainda dificultavam uma coerente tomada de decisões, o que fez com que a empresa se tornasse ineficiente, com custos excessivos e um pesado fardo com os inúmeros empréstimos.

Foi com o trabalho de uma auditora interna, Cynthia Cooper, que se tomou conhecimento das irregularidades contábeis da WorldCom. Transações financeiras suspeitas chamaram a atenção da auditora, que passou a investiga-las em segredo ${ }^{118}$. Sua equipe então descobriu que os balanços da empresa mostravam custos operacionais falsos, com o objetivo de mostrar maiores lucros para a empresa.

Mais uma vez podemos observar o fraco desempenho de politicas internas de controle em uma empresa cujo administrador agia de forma autoritária e o Conselho não exercia suas funções corretamente. A cultura do lucro mostrou-se prejudicial à empresa que não teve controle internos fortalecidos para perceber a tempo a bilionária fraude escondida. A manipulação das informações foi favorecida pela grande descentralização das atividades, que exige dos programas internos maior atenção e responsabilidade dos funcionários e demais stakeholders.

\footnotetext{
${ }^{115}$ HAMILTON, Stewart. MICKLETHWAIT, Alicia. Greed and corporate failure: the lessons from recent disasters. New York: Palgrave Macmillan, 2006. p.73.

${ }^{116}$ PADGET, Tim. The rise and fall of Bernie Ebbers. Revista Time, 05 de maio de 2002. Disponível em: < http://content.time.com/time/magazine/article/0,9171,235450,00.html >. Acesso em 30 de maio de 2016.

${ }^{117}$ ELSTROM, Peter. How to hide $\$ 3.8$ billion in expenses. Bloomberg, 08 de julho de 2002. Disponível em: $<$ http://www.bloomberg.com/news/articles/2002-07-07/how-to-hide-3-dot-8-billion-in-expenses $>$.Acesso em 30 de maio de 2016.

${ }^{118}$ MOBERG, Dennis; ROMAR, Edward. WorldCom Case Study. p. 07.
} 


\subsection{Lehman Brothers}

Os anos 2000 foram a década dos banqueiros, afirma Charles H. Fergunson. Com a desregulamentação desde os anos 80, época de Reagan e Bill Clinton, as práticas de alavancagem tornavam o sistema financeiro ainda mais arriscado e fraudulento ${ }^{119}$. Conforme explica Thiago Navarro Mafra Amorim, "os mercados financeiros sempre foram, são e sempre serão afetados pela interação de oportunidades, incertezas e riscos". Esta exposição geraria vulnerabilidades financeiras que exerceria maior influência em momentos de queda brusca, mudando de forma súbita os ânimos do mercado ${ }^{120}$.

Fundado em 1850, o Lehman Brothers era considerado uma importante instituição financeira, estruturada como um conglomerado, que provia diversos tipos de serviços financeiros em quarenta países diferentes ${ }^{121}$. Para melhor compreensão do caso é necessário que seja feito previamente um breve estudo sobre o fundo de investimentos LTCM (Long Term Capital Management), que utilizava várias técnicas de investimentos agressivas para gerar retornos acima do mercado como, por exemplo, a compra de títulos desvalorizados e a venda de outros supervalorizados. Fundos de hegde teriam por objetivo evitar ou, ao menos, reduzir as perdas geradas por flutuações do mercado ${ }^{122}$ e com a vantagem de gerar altos retornos para os investidores, estes fundos poderiam, igualmente, perder dinheiro de forma bastante eficiente ${ }^{123}$. Com políticas de risco, os investimentos mínimos do fundo LTCM começavam em US\$10 milhões e não poderiam ser retirados em um período inferior a 03 anos, com taxas de administração correspondentes a $25 \%$.

Com a ocorrência de uma crise na Ásia no final da década de $90^{124}$, e devido ao elevado volume de investimentos feito nesta região, o LTCM sofreu com seus erros de cálculo, em grande parte, por causa de apostas alavancadas utilizando derivativos, cuja

\footnotetext{
${ }^{119}$ FERGUNSON, Charles H. O sequestro da América: como as corporações financeiras corromperam os Estados Unidos. Rio de Janeiro: Jorge Zahar Editor Ltda, 2012.p.25.

${ }^{120}$ AMORIM, Thiago Navarro Mafra. Contingência de crises financeiras: um estudo sobre a evolução da regulação dos mercados e o risco das instituições financeiras no Brasil, 2011. p.07.

${ }^{121}$ WALKER, Gary E. (ed). CLARKE, Lindel D. (ed). op.cit. p.06.

${ }^{122}$ KRUGMAN, Paul. A crise de 2008 e a economia da depressão. Rio de Janeiro: Elsevier, 2009.p.124.

${ }^{123}$ KRUGMAN, Paul. op.cit. p.124-125.

${ }^{124}$ No ano de 1997, a desvalorização da moeda tailandesa desencadeou uma grave crise financeira na Ásia. O capital externo aproveitava as taxas de juros elevados, em busca de melhores rendimentos e, como resultado do crescente volume de empréstimos externos houve uma significativa expansão do crédito, incentivando uma nova onda de investimentos. Entretanto, a desvalorização da moeda chinesa, a competição regional e sua mão-de-obra mais barata contribuíram para que as exportações da Tailândia e Malásia fossem reduzidas. Investimentos em projetos duvidosos e com o encarecimento das exportações, "a perda da confiança nos mercados deflagrou um círculo vicioso de colapso econômico e financeiro". KRUGMAN, Paul. op.cit. p.7999.
} 
regulamentação fora considerada desnecessária pouco tempo antes de sua quebra ${ }^{125}$. De acordo com Paul Krugman, no verão de 1998, os fundos estavam envolvidos em ativos arriscados e ilíquidos, e que faltou ao mercado perceber que "a competição entre fundos de hedge para explorar oportunidades de lucro cada vez mais estreitas criara uma espécie de máquina do apocalipse financeiro ${ }^{126 \%}$.

Na ocasião, o banco Lehman Brothers recusou-se a participar de um levantamento de fundos que beneficiaria o LTCM, porém, o FED (Federal Reserve System - Sistema de Reserva Federal) entendeu que o fundo seria "too big to fail" e para evitar uma maior perturbação no mercado e um risco sistêmico, estruturou um acordo entre os próprios bancos para resgatá-1o ${ }^{127}$. O problema neste resgate foi a falsa impressão dado ao mercado de que a tomada de risco exagerada não seria punida. Na ocasião, para o FED, a quebra de um fundo como o LTCM refletiria em todo o mundo financeiro e, desta forma, a melhor saída seria o seu resgate (bailout). Então, um grupo de bancos foi convencido pelo FED a assumir o LTCM em troca do investimento que a empresa necessitava ${ }^{128}$.

O gerenciamento de riscos e um regime de informações não eram considerados de grande importância dentro do Lehman Brothers, porém, para fortalecer sua classificação de crédito, o banco optou por demonstrar que entendia a importância de gerenciar adequadamente os riscos e de uma estrutura que pudesse medir e controla-los ${ }^{129}$. Para isso, era necessário fazer deste gerenciamento uma parte central de suas atividades, perto do Conselho dos diretores e dos demais executivos. Uma medida foi colocar em seu relatório anual o efetivo comprometimento ${ }^{130}$.

Vivia-se um período de euforia baseado em uma "combinação de consumo insustentável e fraude escancarada ${ }^{131}$,, em que uma cadeia de securitizações foi transformada em um "processo extremamente complexo e pouco transparente que integrou

\footnotetext{
${ }^{125}$ FERGUNSON, Charles H. O sequestro da América: como as corporações financeiras corromperam os Estados Unidos. Rio de Janeiro: Jorge Zahar Editor Ltda, 2012.p.55.

${ }^{126}$ KRUGMAN, Paul. A crise de 2008 e a economia da depressão. Rio de Janeiro: Elsevier, 2009.p.139.

${ }^{127}$ WILLIANS, Mark T. Uncontrolled risk: the lessons of Lehman Brothers and how systemic risk can still bring down the world financial system. New York: McGraw-Hill, 2010. p. 86 e ss.

${ }^{128}$ KRUGMAN, Paul. op.cit. p.142.

${ }^{129}$ WILLIANS, Mark T. op.cit. p. 106.

${ }^{130}$ At Lehman Brothers we believe risk management is distinctly different from crisis management. We have clear processes and procedures to support the Guardianship role undertaken by risk management. We define guardianship as identifying, measuring, monitoring and reporting risk. To support this, the Firm has made, and continues to make, a significant investment in technology and people. However, risk management can succeed only if risk management is perceived to be an important part of culture - as is the case at Lehman Brothers. WILLIANS, Mark T. op.cit. p. 110.

${ }^{131}$ FERGUNSON, Charles H. op.cit. p.27.
} 
quase todos os segmentos do sistema financeiro ${ }^{132}$ ". Criou-se um ambiente em que toda Wall Street estava exposta aos riscos do mercado hipotecário subprime ${ }^{133}$.

Inovações financeiras permitiam que os bancos "limpassem seus balanços" de

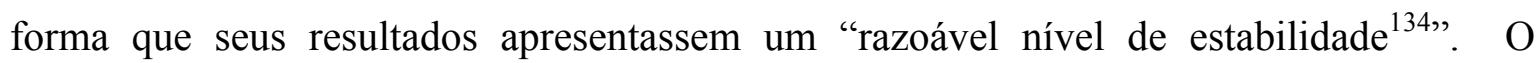
impulsionamento dos negócios prime e subprime, acrescido de taxas de juros baixas que estimulavam os americanos a participar de novas hipotecas criou um "movimento de instituições financeiras no sentido de empacotar milhares de hipotecas, transformando-as em instrumentos securitizáveis nos mercados financeiros globais ${ }^{135 \%}$. A crença em uma constante valorização dos imóveis trouxe a ilusão de que, desde que os preços continuassem subindo, a capacidade do devedor em quitar sua dívida seria de pouca relevância $^{136}$.

Conforme afirma Michael Lewis, "quanto menos transparente o mercado e mais complicados os valores mobiliários, mais dinheiro as mesas de operação das grandes empresas de Wall Street conseguem ganhar com a discussão ${ }^{137}$ ". Não havia comedimento nem por parte dos emprestadores, nem por parte daqueles que tomavam os empréstimos. Métodos contábeis duvidosos e novos tipos de confusos e complicados derivativos tornaram-se instrumentos para a especulação desenfreada ${ }^{138}$. Alguns investidores perceberam esta falta de controle e passaram a investir contra o sistema financeiro, focando em determinados títulos hipotecários duvidosos que tornavam evidente que os empréstimos subprime eram uma bomba-relógio, uma vez consideradas características como a "localização das casas, a falta de documentação e comprovação e a renda do tomador do empréstimo $^{139,}$.

Este mercado subprime atingiu uma grande parcela da população que não estava inserida no contexto de Wall Street. Os empréstimos foram concedidos a um público que possuía menor capacidade creditícia do que $71 \%$ da população norte-americana. Cidadãos

\footnotetext{
${ }^{132}$ FERGUNSON, Charles H. O sequestro da América: como as corporações financeiras corromperam os Estados Unidos. Rio de Janeiro: Jorge Zahar Editor Ltda, 2012.p.48-49.

${ }^{133}$ LEWIS, Michael. A jogada do século. 2.ed. Rio de Janeiro: Editora Best Seller, 2016.p.46.

${ }^{134}$ AMORIM, Thiago Navarro Mafra. Contingência de crises financeiras: um estudo sobre a evolução da regulação dos mercados e o risco das instituições financeiras no Brasil, 2011. p.09.

${ }^{135}$ AMORIM, Thiago Navarro Mafra. op.cit. p.13-14.

${ }^{136}$ KRUGMAN, Paul. A crise de 2008 e a economia da depressão. Rio de Janeiro: Elsevier, 2009.p.155.

${ }^{137}$ LEWIS, Michael. A jogada do século. 2.ed. Rio de Janeiro: Editora Best Seller, 2016.p.107.

${ }^{138}$ LEWIS, Michael. op.cit. p.53-54.

${ }^{139}$ LEWIS, Michael. op.cit. p.76.
} 
americanos refinanciavam imóveis para que pudessem comprar novos imóveis e conforme aumentava o preço dos imóveis, eles continuavam os financiamentos ${ }^{140}$.

O Lehman e outros bancos securitizadores inflaram o valor de seus ativos, e no primeiro caso, "a sobreavaliação mais ofensiva foi sobre sua carteira de imóveis comerciais, cuja avaliação inflacionada em bilhões de dólares foi discutida explicitamente pela alta administração do Lehman no dia anterior à quebra ${ }^{141}$ ". Com essas manobras, os bancos repassavam os títulos para o mercado financeiro global e espalhavam o risco da inadimplência, gerando um propício cenário para uma grave crise ${ }^{142}$. Quando os preços dos imóveis começaram a cair lentamente, as vendas diminuíram e os índices de inadimplência subiram $^{143}$.

Em 2007, o relatório anual enviado aos acionistas mostrava resultados excelentes com mais de US\$1 bilhão em lucros. Neste mesmo ano, os investimentos imobiliários do banco representavam quatro vezes o capital da empresa e o boom dos créditos imobiliários caminhava para o seu fim: a taxa de inadimplência dos empréstimos subprime batia recorde $^{144}$. A complexidade dos financiamentos e operações financeiras que constituíam as bases dos empréstimos subprime tornava ainda mais complicada qualquer tipo de negociação entre credores e devedores ${ }^{145}$.

Após infrutíferas tentativas de venda para outras instituições financeiras, os problemas de liquidez do Lehman Brothers estavam agravando-se, em 2008. Muito foi feito por parte do governo para evitar que famílias, negócios e o próprio sistema não sofressem com os devastadores efeitos da quebra do Lehman Brothers, entretanto, o fim foi intensificado "pelas incontroláveis forças do mercado e pela percepção e rumores de que o Lehman não tinha capital suficiente para sustentar seus investimentos ${ }^{146,}$.

A queda no valor das ações tornou-se uma séria preocupação dentro da empresa e a única saída seria a repetição do que acontecera com o fundo LTCM: uma intervenção do

\footnotetext{
${ }^{140}$ LEWIS, Michael. A jogada do século. 2.ed. Rio de Janeiro: Editora Best Seller, 2016.p.127.

${ }^{141}$ FERGUNSON, Charles H. O sequestro da América: como as corporações financeiras corromperam os Estados Unidos. Rio de Janeiro: Jorge Zahar Editor Ltda, 2012.p.210.

${ }^{142}$ PELLEGRINI, Marcelo. Regulação financeira falha criou mecanismos da crise de 2008. USP Online Destaque, 27 de outubro de 2011.

${ }^{143}$ KRUGMAN, Paul. A crise de 2008 e a economia da depressão. Rio de Janeiro: Elsevier, 2009. p.175.

${ }^{144}$ LEWIS, Michael. op.cit. p. 218.

${ }^{145}$ KRUGMAN, Paul. op.cit. p. 176.

${ }^{146}$ WALKER, Gary E. (ed). CLARKE, Lindel D. (ed). op.cit. p.53 e ss.
} 
governo $^{147}$. Era grande a desconfiança com a segurança do mercado quando considerada a complexidade das operações e a vulnerabilidade das demais instituições financeiras. $\mathrm{O}$ preço das ações reflete as informações disponibilizadas no mercado, então a alta rentabilidade nas operações financeiras "pode ter, de alguma forma, induzido a um excesso de confiança em grandes players do mercado, culminando no impensável processo de bancarrota de tradicionais instituições ${ }^{148,}$.

Em um depoimento, a presidente da SEC, Mary L. Shapiro, afirmou que as razões que influenciaram a quebra do Lehman Brothers envolviam práticas irresponsáveis de empréstimo; a confiança excessiva nas avaliações de créditos por investidores; a visão errônea de que os mercados podem se auto-ajustar, apreciando, assim, padrões fracos e falhas de regulação; a proliferação de complexos produtos financeiros; excessiva tomada de riscos; falta de gerenciamento destes riscos e de uma estrutura interna adequada ${ }^{149}$. Comprar na alta do mercado e não diversificar os investimentos prejudicou a recuperação do Lehman Brothers ${ }^{150}$. Cumpre ressaltar que os títulos considerados lixo em 2009, possuíam classificação de alto grau de investimento, cerca de $90 \%$ deles eram AAA, em $2007^{151}$.

Quando o Lehman foi à falência, descobriu-se que seu presidente, Joe Gregory, tinha um helicóptero particular, elevadores programados para que não visse nenhum dos demais funcionários, que o banco possuía um acervos de obras raras e que seus altos dirigentes haviam retirado coletivamente um bilhão de dólares nos anos anteriores ao colapso $^{152}$. Não se pode afirmar que seus administradores não estavam cientes da situação caótica do banco, especialmente quando seu vice-presidente sênior, Matthew Lee, que possuía a responsabilidade de supervisionar o balanço global da empresa, afirmou que os livros e registros continham "aproximadamente cinco bilhões em ativos acima do que é administrado", e que não havia um controle suficiente dos ativos do banco, além de “bilhões de dólares em balanços não consolidados, que podem ou não ser ativos 'ruins' ou

\footnotetext{
${ }^{147}$ WILLIANS, Mark T. Uncontrolled risk: the lessons of Lehman Brothers and how systemic risk can still bring down the world financial system. New York: McGraw-Hill, 2010. p.161.

${ }^{148}$ AMORIM, Thiago Navarro Mafra. Contingência de crises financeiras: um estudo sobre a evolução da regulação dos mercados e o risco das instituições financeiras no Brasil, 2011. p.46-65.

${ }^{149}$ WALKER, Gary E. (ed). CLARKE, Lindel D. (ed). The Lehman Brothers Bankruptcy: analyses. New York: Nova, 2012. p.97-98.

${ }^{150}$ WILLIANS, Mark T. op.cit. p.152-153.

${ }^{151}$ FERGUNSON, Charles H. O sequestro da América: como as corporações financeiras corromperam os Estados Unidos. Rio de Janeiro: Jorge Zahar Editor Ltda, 2012.p.121.

${ }^{152}$ FERGUNSON, Charles H. op.cit. p.129-131.
} 
sem desempenho ou passivos reais". Por fim, afirmou nesta carta escrita aos administradores e CFO, escreveu que não acreditava que a empresa tivesse "investido o suficiente nos sistemas financeiros e no pessoal exigido e razoavelmente necessário para lidar com o balanço aumentado ${ }^{153}$ ".

Uma das lições aprendidas com a crise de 2008 é que nenhuma instituição financeira, não importando o seu tamanho, complexidade ou diversificação seria considerada inquebrável e que o sistema estaria integrado demais para suportar esta quebra $^{154}$. Porém, diante do resgate de outras companhias, como as firmas de hipoteca Fannie Mae e Freddie Mac e a participação do Tesouro Americano na compra do banco Bear Stearns pelo JP Morgan, chegou-se a afirmar uma possível decisão (escolha) política da quebra do Lehman Brothers. Sem qualquer proteção às demais partes, o Departamento do Tesouro permitiu que a empresa fechasse após considerar que as consequências de seu colapso não seriam muito graves ${ }^{155}$. Diante da consequência totalmente oposta, as agências governamentais alegaram que não tinham autoridade suficiente para socorrer o banco ${ }^{156}$. Outras instituições financeiras como Goldman Sachs, Morgan Stanley e Citigroup, por exemplo, receberam bilhões de dólares do Tesouro norte-americano, sem que nenhuma providência fosse efetivamente cobrada ${ }^{157}$.

Críticos afirmam que o FED falhou ao não identificar corretamente os riscos da falência de uma instituição financeira tão grande e complexa, nem seus efeitos colaterais. A complexidade do conglomerado e a natureza contraditória de um processo de falência foram as responsáveis pelas vastas desavenças judiciais pelos ativos e o atraso no pagamento das indenizações ${ }^{158}$. O comportamento generalizado também dificultou que se apontassem responsáveis individuais específicos ${ }^{159}$.

\footnotetext{
${ }^{153}$ FERGUNSON, Charles H. O sequestro da América: como as corporações financeiras corromperam os Estados Unidos. Rio de Janeiro: Jorge Zahar Editor Ltda, 2012.p.215-218.

${ }^{154}$ WALKER, Gary E. (ed). CLARKE, Lindel D. (ed). The Lehman Brothers Bankruptcy: analyses. New York: Nova, 2012. p.01.

${ }^{155}$ KRUGMAN, Paul. A crise de 2008 e a economia da depressão. Rio de Janeiro: Elsevier, 2009.p.186-187.

${ }^{156}$ LEWIS, Michael. A jogada do século. 2.ed. Rio de Janeiro: Editora Best Seller, 2016.p.306.

${ }^{157}$ LEWIS, Michael. op.cit. p.308.

${ }^{158}$ WALKER, Gary E. (ed). CLARKE, Lindel D. (ed). op.cit. p.18. Processos de falência são tipicamente desafiadores em importantes instituições financeiras, em parte, porque os envolvidos possuem pouco tempo ou oportunidade de preparação e coordenação. WALKER, Gary E. (ed). CLARKE, Lindel D. (ed). op.cit. p.37.

${ }^{159}$ SCHÜNEMANN, Bernd. A chamada "crise financeira" - falha sistêmica ou criminalidade globalmente organizada? In: GRECO, Luís (Coord.); SCHÜNEMANN, Bernd. Estudos de direito penal, direito processual penal e filosofia do direito. São Paulo: Marcial Pons, 2013. p.190.
} 
A soma de um mercado pouco transparente, fundamentado em operações complexas e inovações financeiras avaliadas de forma incoerente envolveram todo o sistema em uma rede de especulações e desconfiança. A grave crise de 2008 foi provocada pelo comportamento fraudulento de diversos indivíduos e de uma falha sistêmica que permitiu especulações perigosas e o colapso do sistema financeiro, não só nos EUA, berço das hipotecas, mas diante da interligação dos mercados, em todo mundo. 


\section{O DIREITO PENAL ECONÔMICO E A EXPANSÃO DO DIREITO PENAL NO ÂMBITO EMPRESARIAL}

\subsection{O Direito penal econômico}

Ao longo do século XX, pós-crise de 1929 e após as duas Grandes Guerras, aperfeiçoa-se o que se convencionou chamar de direito penal econômico. A este ramo do direito foi atribuída a tutela das atividades econômicas regulamentadas não apenas pelo Estado, mas por associações cujo escopo fosse o aumento e a justa distribuição de bens na sociedade $^{160}$. Um conjunto de normas, promulgadas para a regulação da produção, fabricação e distribuição de bens econômicos ${ }^{161}$, cujo objeto seria sancionar condutas que ofendessem ou expusessem a perigo bens jurídicos relevantes ${ }^{162}$, sendo seu papel no mundo cada vez maior, considerando sua ligação à qualidade e grau de intervenção do Estado na vida econômica.

A criminalidade econômica desenvolveu-se de forma técnica, refinada e paralela ao aumento da complexidade das sociedades modernas, especialmente na área econômica ${ }^{163}$. Neste sentido, Manoel Pedro Pimentel afirma que o direito penal econômico não é autônomo, mas trata-se de um ramo do direito penal comum e sujeito aos mesmos princípios fundamentais deste, sendo regulado por um conjunto de leis especiais editadas sob a pressão de necessidades novas, cuja autonomia poderia se converter em uma intolerável arma de opressão estatal e coerção ${ }^{164}$.

João Marcello de Araújo Jr explica que em uma economia de mercado frágil, como ele entende ser o caso brasileiro, seria indispensável uma regulação jurídica das violações da ordem econômica ${ }^{165}$, partindo do direito penal econômico e de seus princípios liberais e

\footnotetext{
${ }^{160}$ JAPIASSU, Carlos Eduardo Adriano; PEREIRA, Daniel Queiroz. Direito Penal econômico e tributário: uma análise histórica e comparada. In: SOUZA, Artur de Brito Gueiros (org). Inovações no Direito Penal Econômico: Contribuições criminológicas, político-criminais e dogmáticas. Brasília: Escola Superior do Ministério Público da União, 2011. p.250.

${ }^{161}$ BERRUEZO, Rafael. op.cit. p.05.

${ }^{162}$ Para Manoel Pedro Pimentel, o direito penal econômico pode ser conceituado como um "conjunto de normas que tem por objeto sancionar, com as penas que lhe são próprias, as condutas que, no âmbito das relações econômicas, ofendam ou exponham a perigo bens ou interesses juridicamente relevantes". O autor coloca em destaque a finalidade de proteger os bens e os interesses humanos relacionados com a economia. PIMENTEL, Manoel Pedro. op.cit. p. 10.

${ }^{163}$ PIMENTEL, Manoel Pedro. op.cit. p. 05.

${ }^{164}$ PIMENTEL, Manoel Pedro. op.cit. p.15-16.

${ }^{165}$ ARAUJO JUNIOR, João Marcello de. O direito penal econômico. Revista Brasileira de Ciências Criminais, São Paulo, v. 7, n. 25, jan./mar. 1999. p.149-150.
} 
garantistas destinados a fazer funcionar a política econômica. Assim, o direito penal econômico seria destinado a regular o comportamento daqueles que participam do mercado e a proteger e estruturar o seu funcionamento e a politica econômica estatal ${ }^{166}$. Neste sentido, as restrições introduzidas pelo direito penal econômico buscariam preservar a liberdade no mundo econômico e não violariam a intervenção mínima caracterizadora do direito penal ${ }^{167}$.

Klaus Tiedemann estabelece uma conexão entre o crime de colarinho branco desenvolvido por Sutherland e a atividade econômica, concluindo que "a particularidade do delito econômico ${ }^{168}$ reside menos na personalidade do autor e seu pertencimento a uma classe social elevada e mais à especial maneira de comissão (modus operandi), assim como o objeto deste comportamento ${ }^{169}$ ". Em uma perspectiva criminológica, Tiedemann afirma que o direito penal econômico estaria relacionado com condutas próprias do exercício profissional realizadas por um grupo específico de autores ${ }^{170}$. Já o conceito de criminalidade da empresa, conforme explicado por Bernd Schünemann, seria o âmbito dos delitos econômicos e a forma como as empresas lesionam bens jurídicos e interesses externos, como os seus interesses próprios e os bens jurídicos dos seus colaboradores ${ }^{171}$.

O conceito de direito penal econômico abarcaria, desta forma, as partes do direito penal que tutelam, principalmente, o bem constituído pela ordem econômica em seu conjunto e, por consequência, o fluxo da economia nacional ${ }^{172} \mathrm{e}$, diante disto, seria concebido como o "direito da direção da Economia pelo Estado ${ }^{173}$ ". Entretanto, para Schünemann, não existiria um tipo unitário de crimes econômicos, uma vez que qualquer um que participasse da vida econômica e social poderia tornar-se um delinquente, diante de

\footnotetext{
${ }^{166}$ ARAUJO JUNIOR, João Marcello de. op.cit. p.150.

${ }^{167}$ JAPIASSU, Carlos Eduardo Adriano; PEREIRA, Daniel Queiroz. Direito Penal econômico e tributário: uma análise histórica e comparada. In: SOUZA, Artur de Brito Gueiros (org). Inovações no Direito Penal Econômico: Contribuições criminológicas, político-criminais e dogmáticas. Brasília: Escola Superior do Ministério Público da União, 2011. p. 257.

${ }^{168}$ Para Rafael Berruez, o ato que viola o interesse do Estado na integridade e conservação do seu sistema econômico, é considerado um delito econômico. BERRUEZO, Rafael. op.cit. p.16.

${ }^{169}$ TIEDEMANN, Klaus. El concepto de derecho económico, de derecho penal económico y de delito económico. Cuadernos de política criminal, Madrid, n. 28, 1986. p. 66.

${ }^{170}$ TIEDEMANN, Klaus. Manual de Derecho Penal Económico: parte general y especial. Valencia: Ed. Tirant lo Blanch, 2010. p. 57.

${ }^{171}$ SCHÜNEMANN, Bernd. Cuestiones básicas de dogmática jurídico-penal y de política criminal acerca de la criminalidad de empresa. Anuario de derecho penal y ciencias penales, Madrid, v. 41, n. 2, mai./ago. 1988. p. 531.

${ }^{172}$ TIEDEMANN, Klaus. El concepto de derecho económico, de derecho penal económico y de delito económico. Cuadernos de política criminal, Madrid, n. 28, 1986. p. 73.

${ }^{173}$ TIEDEMANN, Klaus. Poder Económico y Delito. Barcelona: Ed. Ariel, 1985. p. 19.
} 
oportunidade e falta de controle suficiente ${ }^{174}$. Tais delitos são, portanto, feitos puníveis cometidos por alguém no exercício de sua profissão, cuja regulamentação encontra-se não no Código Penal, mas anexa às leis que regulam a atividade econômica ${ }^{175}$.

Deve-se destacar a crescente internacionalização dos delitos econômicos, em que as empresas multinacionais apresentam um papel de destaque, com suas filiais em numerosos Estados $^{176}$. Joachim Vogel explica que as atuais sociedades são regidas por uma pluralidade de sistemas legais, constituindo uma "interlegalidade", que ele afirma ser o fenômeno chave do direito penal da globalização ${ }^{177}$. Pode-se perceber que a expansão que acompanhamos atualmente do direito penal demonstra uma "percepção mais ligada aos mercados do que a uma filosofia individual liberal ${ }^{178, "}$

Para Navarro Dolmestch três seriam as características do direito penal da globalização: uma tendência à expansão, caracterizada pelo abrandamento do rigor do princípio da legalidade através da incorporação de tipos penais cada vez mais abertos e fundamentados na prevenção; uma permanente flexibilização das regras de imputação e das garantias processuais em uma lógica de direito penal máximo e na necessidade de unificação, em que o contexto globalizado demanda questões penais fundamentalmente práticas, buscando do direito penal eficácia no combate especialmente à criminalidade econômica $^{179}$.

Analisar os objetivos do direito penal econômico, especialmente em um contexto de grandes empresas e novos riscos nos permite encontrar formas necessárias para uma regulação planejada que não tenha por objetivo dar respostas apressadas a desvios de condutas empresariais, mas que a partir da participação de todos os interessados seja possível encontrar adequadas formas de controle que não engessem a produção econômica e permitam uma integração dos conhecimentos.

\footnotetext{
${ }^{174}$ TIEDEMANN, Klaus. La criminalidad económica como objeto de investigación. Cuadernos de política criminal, Madrid, n. 19, 1983. p.171.

${ }^{175}$ TIEDEMANN, Klaus. op.cit. p. 172.

${ }^{176}$ TIEDEMANN, Klaus. Derecho penal económico: introducción y parte general. San José: Grijley, 2009. p.49.

${ }^{177}$ VOGEL, Joachim. op.cit. p.117.

${ }^{178}$ SILVEIRA, Renato de Mello Jorge; SAAD-DINIZ, Eduardo. Compliance, Direito Penal e Lei Anticorrupção. São Paulo: Saraiva, 2015.p.352.

${ }^{179}$ NAVARRO DOLMESTCH, Roberto. Reconfiguración del sistema de fuentes del derecho penal y amenaza de crisis del principio de legalidad: la incorporación del derecho internacional convencional y el fenómeno de la globalización. In: FARALDO CABANA, Patricia. Nuevos retos del derecho penal en la era de la globalización. Valencia: Tirant lo Blanch, 2004. p.160-164.
} 


\subsection{Possíveis implicações da expansão do direito penal econômico}

Nas palavras de Ulrich Beck, o aparecimento da globalização permitiu aos empresários a reconquista de um poder perdido durante o Estado do bem-estar social ${ }^{180}$. Com a limitação e enfraquecimento dos Estados-nação, desenvolveram-se novas relações e estruturas nos processos produtivos, nas quais as grandes corporações passaram a desempenhar um papel de destaque dentro das economias nacionais ${ }^{181}$. A tecnologia, inovações e o maior fluxo de informações ainda que benéficos, teriam um lado perigoso, trazendo grande interdependência entre instituições financeiras e empresas ${ }^{182}$. Considerando que a globalização encontra-se vinculada ao incremento da atividade econômica, a criminalidade econômica, neste contexto, crescerá $^{183}$, difícultando o controle por parte do Estado.

A globalização econômica, na qual "sistemas técnico-científicos, produtivos, financeiros e comerciais se especializam e se subdividem continuamente, produzindo suas próprias regras, seus próprios procedimentos e suas próprias racionalidades e concepções de justiça”, enfraqueceu as legislações nacionais, demandando do Estado normas específicas, voltadas a fins e contextos determinados ${ }^{184}$.

A pretensa política criminal da expansão penal em relação a riscos na economia seria o resultado de uma política que busca a proteção e o desenvolvimento social frente à atuação delituosa da classe alta ${ }^{185}$, uma necessidade, nas palavras de Manoel Pedro Pimentel, "a fim de regularizar as relações negociais, coibindo os abusos de poder econômico e a exploração dos fracos pelos fortes ${ }^{186}$ ". Quando se tem por objetivo proteger a ordem econômica, o bem jurídico afasta-se dos tradicionais crimes patrimoniais ${ }^{187} \mathrm{e}$, diante de uma provável avaliação dos problemas em uma sociedade globalizada, é trazida a

\footnotetext{
${ }^{180} \mathrm{BECK}$, Ulrich. O que é globalização? Equívocos do globalismo, respostas à globalização. São Paulo: Editora Paz e Terra, 1999.p.14.

${ }^{181}$ IANNI, Octavio. Teorias da Globalização. Rio de Janeiro: Ed. Civilização Brasileira, 2004. p.56.

${ }^{182}$ FERGUNSON, Charles H. O sequestro da América: como as corporações financeiras corromperam os Estados Unidos. Rio de Janeiro: Jorge Zahar Editor Ltda, 2012.p.241.

${ }^{183}$ VOGEL, Joachim. Derecho penal y globalización. Anuario de la Facultad de Derecho de la Universidad Autonoma de Madrid. n.9, 2005. p.115.

${ }^{184}$ BICUDO, Tatiana Viggiani. A globalização e as transformações do direito penal. In: Revista Brasileira de Ciências Criminais, São Paulo, ano 6, n. 23, julho-setembro, 1998. p.99.

${ }^{185}$ SILVEIRA, Renato de Mello Jorge. Direito penal econômico como direito penal de perigo. São Paulo: Revista dos Tribunais, 2006. p. 177.

${ }^{186}$ PIMENTEL, Manoel Pedro. Direito Penal Econômico. São Paulo: Revista dos Tribunais, 1973. p.06.

${ }^{187}$ ARAUJO JUNIOR, João Marcello de. O direito penal econômico. Revista Brasileira de Ciências Criminais, São Paulo, v. 7, n. 25, jan./mar. 1999. p.153.
} 
discussão dos limites para a intervenção penal no âmbito econômico em uma tutela penal dos poderosos ${ }^{188}$.

Existiria uma estreita relação entre o direito penal econômico e as ciências empresariais, especialmente quando tratamos de assuntos como a contabilidade comercial, auditorias contábeis, a relevância das informações no mercado financeiro e na valoração das condutas empresariais ${ }^{189}$. Assim, o ordenamento teria que garantir as liberdades econômicas necessárias e, ao mesmo tempo, evitar fraudes que se desenvolvessem além dos limites dos riscos permitidos pelo sistema ${ }^{190}$. O Estado, antes excluído pelas políticas de desregulamentação, foi chamado para corrigir os problemas criados pelas práticas do livre mercado ${ }^{191}$.

Observa-se que a diminuição do poder estatal em diversas áreas, como na economia, vem sendo compensada pelo reforço do poder punitivo com o discurso de novas criminalizações $^{192}$. O presente momento do direito penal, caracterizado por Renato de Mello Jorge Silveira pela omissão, considera que a vigilância passou a ocupar um papel central dentro das atividades empresariais, expandindo-se a via omissiva, na qual haverá maior responsabilidade criminal dos empresários que não fizerem o que era possível e exigível na prevenção dos atos lesivos ${ }^{193}$. Traz este entendimento Bernd Schünemann ao afirmar que a busca atual do direito penal estaria na prevenção e não mais na retribuição ${ }^{194}$.

As novas orientações da legislação penal e de política criminal derivariam, então, de um direito penal globalizado e harmonizado que parte do pressuposto de que os

\footnotetext{
${ }^{188}$ SILVEIRA, Renato de Mello Jorge. Direito penal econômico como direito penal de perigo. São Paulo: Revista dos Tribunais, 2006. p. 23.

${ }^{189}$ TIEDEMANN, Klaus. Derecho penal económico: introducción y parte general. San José: Grijley, 2009. p.63.

${ }^{190}$ SICA, Leonardo. Tutela penal da ordem econômica no direito brasileiro: comparação entre as leis n.8137/90 e 8884/94. In: VILARDI, Celso Sanchez (org). PEREIRA, Flávia Rahal Bresser (org). DIAS NETO, Theodomiro. Direito Penal Econômico: Análise Contemporânea. São Paulo: Saraiva, 2009. p. 176.

${ }^{191}$ SARCEDO, Leandro. Compliance e Responsabilidade Penal da Pessoa Jurídica: Construção de um novo modelo de imputação, baseado na culpabilidade corporativa. Faculdade de Direito, Universidade de São Paulo, São Paulo, 2014.p.30.

${ }^{192}$ SICA, Leonardo. op.cit. p. 149.

${ }^{193}$ SILVEIRA, Renato de Mello Jorge; SAAD-DINIZ, Eduardo. Compliance, Direito Penal e Lei Anticorrupção. São Paulo: Saraiva, 2015. p.130. Neste sentido, Tatiana Viggiani BICUDO enfatiza a falta de preocupação com os problemas passados do novo direito penal, uma vez que este passa a focar na prevenção de violações futuras. BICUDO, Tatiana Viggiani. A globalização e as transformações do direito penal. In: Revista Brasileira de Ciências Criminais, São Paulo, ano 6, n. 23, julho-setembro, 1998. p.107.

${ }^{194}$ SCHÜNEMANN, Bernd. Do templo ao mercado? Como a justiça penal aparentemente transforma a teoria econômica do direito em prática, governo em governança e soberania em cooperação. In: GRECO, Luís (Coord.); SCHÜNEMANN, Bernd. Estudos de direito penal, direito processual penal e filosofia do direito. São Paulo: Marcial Pons, 2013. p.313.
} 
ordenamentos nacionais encontram-se impotentes frente à criminalidade que atua de forma transnacional ${ }^{195}$. Conforme afirma Octavio Ianni, "as transnacionais movimentam seus recursos, desenvolvem suas alianças, agilizam suas redes e circuitos de modo independente, com total desconhecimento dos governos nacionais", realizando seus próprios planejamentos que raramente contemplam as fronteiras nacionais ${ }^{196}$. Os princípios envolvidos nas práticas de mercado implicam uma generalização de padrões e formas de organização social e do trabalho ${ }^{197}$.

O direito desempenha um importante papel nesta harmonização de condutas, através da "codificação jurídica das responsabilidades, normas e procedimentos, estipulando os parâmetros das ações e relações, das instituições e organizações ${ }^{198 \text { ", }}$ Entretanto, a construção legislativa do direito penal econômico não pode consistir apenas na importação de novas leis penais e critérios de imputação expansivos, sem uma adequação destas leis de acordo com as particularidades da realidade a ser disciplinada ${ }^{199}$. De acordo com Roberto Navarro Dolmestch, o processo de criação normativo produzido pela comunidade internacional será feito com a influência de diversas culturas, cujas valorações podem diferir de acordo com o país ${ }^{200}$. Ainda que haja uma demanda de integração mundial das formas de proteção a diferentes bens jurídicos vinculados às práticas econômicas, há a necessidade de observação das particularidades de cada ordenamento, para que "novos institutos presentes no direito alienígena não se transformem em alienígenas no direito pátrio ${ }^{201 "}$.

\footnotetext{
${ }^{195}$ VOGEL, Joachim. Derecho penal y globalización. Anuario de la Facultad de Derecho de la Universidad Autonoma de Madrid. n.9, 2005. p.118-119. Neste sentido, afirma Leandro Sarcedo que há um "reconhecimento implícito de que cada país não é capaz de dar ao problema a solução adequada por meio da aplicação dos instrumentos de controle tradicionais". SARCEDO, Leandro. Compliance e Responsabilidade Penal da Pessoa Jurídica: Construção de um novo modelo de imputação, baseado na culpabilidade corporativa. Faculdade de Direito, Universidade de São Paulo, São Paulo, 2014.p.36.

${ }^{196}$ IANNI, Octavio. Teorias da Globalização. Rio de Janeiro: Ed. Civilização Brasileira, 2004. p.66.

${ }^{197}$ IANNI, Octavio. op.cit. p.102.

${ }^{198}$ IANNI, Octavio. op.cit. p. 156 .

${ }^{199}$ TERRADILLOS BASOCO, Juan Maria. Concepto y método del derecho penal económico. In: ARROYO ZAPATERO, Luis (dir.). LASCANO, Carlos (dir.). NIETO MARTIN, Adán. Derecho penal de la empresa: del derecho penal economico del Estado social al derecho penal de la empresa globalizado. Buenos Aires: Ediar, 2012.p.109.

${ }^{200}$ NAVARRO DOLMESTCH, Roberto. Reconfiguración del sistema de fuentes del derecho penal y amenaza de crisis del principio de legalidad: la incorporación del derecho internacional convencional y el fenómeno de la globalización. In: FARALDO CABANA, Patricia. Nuevos retos del derecho penal en la era de la globalización. Valencia: Tirant lo Blanch, 2004. p.151.

${ }^{201}$ SILVEIRA, Renato de Mello Jorge; SAAD-DINIZ, Eduardo. Compliance, Direito Penal e Lei Anticorrupção. São Paulo: Saraiva, 2015.p.352.
} 
A criminalidade econômica mostra-se de forma sofisticada considerando que as práticas utilizadas, a internacionalização do capital e das empresas, a diminuição das fronteiras nacionais com o desenvolvimento tecnológico e a circulação de informações, resultam no enfraquecimento dos Estados nacionais como repressores de crimes ${ }^{202}$. Para Eugenio Zaffaroni o poder punitivo nacional teria pouca ou nenhuma eficácia preventiva nos delitos econômicos, sendo "necessário um sério replanejamento estrutural, inclusive no plano internacional ${ }^{203}$,

Neste sentido, a internacionalização da criminalidade, para Klaus Tiedemann, exigiria medidas internacionais de combate, espaços jurídicos e econômicos de alguma forma uniformemente estruturados e que formassem uma jurisdição comum supranacional $^{204}$. A integração da economia afetaria a aplicação da lei penal no espaço (princípio da territorialidade) e a globalização tenderia a unificar padrões antes distintos, dificultando a esperada padronização das sanções criminais ${ }^{205}$. A tendência mundial de um desenvolvimento de um Direito global envolveriam duas características: top down (harmonização de normas penais) ou bottom up (mercado acaba por intuir as necessidades de nivelamento) ${ }^{206}$.

Para Joachim Vogel, o direito penal e a pena seriam convertidos, progressivamente, em um mecanismo de intervenção diante do fracasso da prevenção, no papel do "porrete" que acompanharia a "cenoura" dos estímulos positivos para o comportamento conforme a norma (compliance $)^{207}$. Um direito penal desprovido de um lastro dogmático e voltado às preferências de "gestores atípicos da moral" perde seu objetivo e sua legitimidade, gerando, apenas, insegurança ${ }^{208}$. O agravamento de penas, a supressão de garantias

\footnotetext{
${ }^{202}$ ROYSEN, Joyce. Histórico da criminalidade econômica. Revista Brasileira de Ciências Criminais, São Paulo, v. 11, 42 Esp, jan./mar. 2003. p.195.

${ }^{203}$ ZAFFARONI, Eugenio Raúl. O papel do direito penal e a crise financeira. In: SAAD-DINIZ, Eduardo (org.); BRODOWSKI, Dominik (org.); SÁ, Ana Luiza de (org.). Regulação do abuso no âmbito corporativo: o papel do direito penal na crise financeira. São Paulo: Editora LiberArs, 2015.p.15.

${ }^{204}$ TIEDEMANN, Klaus. Derecho penal económico: introducción y parte general. San José: Grijley, 2009. p.51.

${ }^{205}$ BERRUEZO, Rafael. Derecho penal económico. In: BERRUEZO, Rafael et al. Derecho penal económico, Buenos Aires: Editorial B de f., 2010. p.13. SILVEIRA, Renato de Mello Jorge; NETTO, Alamiro Velludo Salvador. Sarbanes-Oxley-act e os vícios do direito penal globalizado. Revista Ultima Ratio, Rio de Janeiro, v. 1, n. 0, 2006. p.204.

${ }^{206}$ SILVEIRA, Renato de Mello Jorge. A atual percepção sobre o fenômeno da corrupção: questão penal, econômica ou de direitos humanos?. Revista do Advogado, São Paulo, v. 34, n. 125, dez. 2014. p.135.

${ }^{207}$ VOGEL, Joachim. Derecho penal y globalización. Anuario de la Facultad de Derecho de la Universidad Autonoma de Madrid. n.9, 2005. p.119.

${ }^{208}$ SILVEIRA, Renato de Mello Jorge. Direito penal econômico como direito penal de perigo. São Paulo: Revista dos Tribunais, 2006.p.183.
} 
processuais e o alargamento de responsabilização pela criação de novas posições de garantidores, especialmente pela grande dificuldade em individualizar condutas nos contextos corporativos, fazem com que surjam leis com técnicas extremamente inseguras e sem comprovação de eficácia. Estaríamos diante, portanto, conforme afirma Silva Sánchez, de um direito penal da globalização econômica e da integração supranacional, um direito menos garantista, com regras de imputação flexibilizadas e garantias político-criminais relativizadas $^{209}$.

Com o objetivo de expandir os international legal standards, observamos uma flexibilização dos ordenamentos jurídicos internos, que passam a ser integrados de maneira supranacional por vias penais caracterizadas por tendências punitivistas ${ }^{210}$. Para que esta integração seja possível, a simetria de informações desempenha um papel de destaque.

A modernização acelerada e uma crescente necessidade por segurança, para Cornelius Prittwitz, deixaram o direito penal em uma encruzilhada entre abandonar ou insistir em seu perfil garantista ${ }^{211}$. Para o autor, a preocupação aqui observada com os crimes econômicos deveria ser estendida também aos menos poderosos ${ }^{212}$, especialmente, ao observarmos o caráter evidentemente seletivo do sistema punitivo. Ao afirmar ainda que tais garantias raramente são consideradas, Prittwitz entende que não caberia ao direito penal "resolver problemas sistêmicos de nossa sociedade moderna ${ }^{213}$ ".

De acordo com Zaffaroni, ainda que os poderes econômico e financeiro possam ocasionar sérios danos sociais, a extensão do direito penal a estas situações poderia, apenas, reforçar o poder punitivo formal, deixando em segundo plano outras medidas estruturais importantes. Entende Zaffaroni que não se pode exigir do direito penal que acompanhe e enfrente "impertinências dissimuladas e encobertas com tecnicismos e

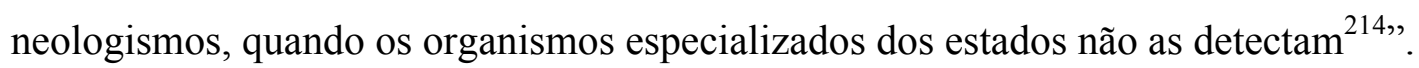

\footnotetext{
${ }^{209}$ SILVA SÁNCHEZ, Jesús María. A expansão do direito penal: aspectos da política criminal nas sociedades pós-industriais. 3. ed. São Paulo: Revista dos Tribunais, 2013. p. 97.

${ }^{210}$ SAAD-DINIZ, Eduardo. Fronteras del normativismo: a ejemplo de las funciones de la información en los programas de criminal compliance. Revista da Faculdade de Direito, v. 108, 2013. p.02-03.

${ }^{211}$ PRITTWITZ, Cornelius. O Direito Penal em uma encruzilhada: abolição, diversificação, retornar à razão ou entrar em razão? Revista de Ciências Jurídicas - UEM, vol. 7, nº.01, jan/jun. 2009. p.26.

${ }^{212}$ PRITTWITZ, Cornelius. op.cit. p.31.

${ }^{213}$ PRITTWITZ, Cornelius. op.cit. p.40.

${ }^{214}$ ZAFFARONI, Eugenio Raúl. O papel do direito penal e a crise financeira. In: SAAD-DINIZ, Eduardo (org.); BRODOWSKI, Dominik (org.); SÁ, Ana Luiza de (org.). Regulação do abuso no âmbito corporativo: o papel do direito penal na crise financeira. São Paulo: Editora LiberArs, 2015.p.19.
} 
Para Juan Terradillos Basoco, a identificação, nas empresas, de âmbitos específicos e a existência de elementos próprios não justificariam uma legitimidade das ambições autonomistas de um pretendido direito penal da empresa ${ }^{215}$. A diferença com o direito penal clássico não residiria em mecanismos excepcionais de imputação, mas na modalidade operativa utilizada para delinquir ${ }^{216}$. Para o autor, mais importante seria a necessidade de maior atenção por parte do legislador aos bens jurídicos mais ameaçados no ambiente da atividade empresarial e decidir, então, sobre as técnicas jurídico-penais mais idôneas para combater os delitos protagonizados pela empresa como sujeito econômico. Ou seja, entende que é preciso uma rigorosa observação do princípio da lesividade e considerar que a atividade empresarial reúne características específicas cujo desconhecimento é peça de ineficácia preventiva ${ }^{217}$.

As características do ambiente econômico-empresarial e sua delinquência específica tornam importante considerar a determinação sobre até que ponto o titular da empresa ou da capacidade de decisão pode responder pelo comportamento de seus subordinados e até onde poderia responder quem atuou como um representante ${ }^{218}$. Em um mercado globalizado, cercado de complexas informações, a desconfiança de consumidores e investidores demanda uma segurança de que, não importando a atividade escolhida, critérios racionais, administradores capazes e controles suficientes para evitar abusos de poder e surpresas negativas ${ }^{219}$. Nas palavras de Nieto Martín, o desafio lançado pela globalização ao direito penal não é aumentar sua incidência, mas torná-lo mais eficaz, reforçando estratégias que considerem a colaboração das empresas ${ }^{220}$.

No âmbito econômico, o uso do direito penal não deve ser feito de forma impulsiva, especialmente quando consideramos sua seletividade também nos delitos econômicos, uma vez que grandes corporações podem com seus elevados padrões de compliance, influenciar o mercado e instrumentalizar o poder punitivo, eliminando concorrentes ${ }^{221}$. O uso das

\footnotetext{
${ }^{215}$ TERRADILLOS BASOCO, Juan M. Cuestiones actuales de derecho penal económico y de la empresa. Lima: Ara, 2010. p. 27.

${ }^{216}$ TERRADILLOS BASOCO, Juan M. op.cit. p. 28.

${ }^{217}$ TERRADILLOS BASOCO, Juan M. op.cit. p. 28.

${ }^{218}$ TERRADILLOS BASOCO, Juan M. op.cit. p. 35-36.

${ }^{219}$ NIETO MARTÍN, Adán. El programa político-criminal del corporate goverment: derecho penal de la empresa y gobierno corporativo. Revista Aranzadi de derecho y proceso penal, Navarra, n. 11, 2004. p.274. ${ }^{220}$ NIETO MARTÍN, Adán. op.cit. p.275-276.

${ }^{221}$ ZAFFARONI, Eugenio Raúl. O papel do direito penal e a crise financeira. In: SAAD-DINIZ, Eduardo (org.); BRODOWSKI, Dominik (org.); SÁ, Ana Luiza de (org.). Regulação do abuso no âmbito corporativo: o papel do direito penal na crise financeira. São Paulo: Editora LiberArs, 2015. p.15.
} 
práticas de compliance com o intuito de melhorar o rating reputacional da empresa não impede a criminalidade econômica e ainda favorecem a aparição de novos riscos penais ${ }^{222}$.

Também para Nieto Martín, deve o direito penal contribuir para formalizar os sistemas de cumprimento empresariais, dando-lhes maiores garantias e valores característicos do direito penal liberal, auxiliando com a regulação dos canais de denúncia, na imposição de sanções e mesmo na realização das investigações internas ${ }^{223}$. Ciente da importância da participação como mantenedor de garantias não observadas no direito administrativo, o que se propõe com o presente trabalho é demonstrar que as boas práticas e a ética empresarial precisam ser internalizadas pelos atores econômicos em nome de um mercado mais justo e confiável, evitando, assim, o uso indiscriminado de normas penais como forma de proteger o bom funcionamento do mercado.

\subsection{A intervenção penal na atividade econômica}

A atuação do Estado na economia tem por objetivo colocar ordem e impor condicionamentos à atividade econômica ${ }^{224}$. Após a crise de 1929, o papel do Estado como "simples árbitro do jogo econômico ${ }^{225 " ~ p e r d e u ~ a ~ r a z a ̃ o ~ e ~ o ~ d e s e n v o l v i m e n t o ~ d o ~ p a i ́ s ~ p a s s o u ~}$ a constituir o seu objetivo fundamental e não mais um produto do jogo de forças do mercado $^{226}$.

A partir do século XX, conforme explica Gilberto Bercovici, as constituições federais passam a conter normas de competência para a elaboração e implementação da política econômica e estabelecem os fundamentos jurídicos para as medidas econômicos a serem tomadas pelo Estado ${ }^{227}$. Nossa Constituição Federal de 1988 caracteriza-se como

\footnotetext{
${ }^{222}$ MONTIEL, Juan Pablo. Autolimpeza empresarial: compliance programs, investigaciones internas y neutralización de riesgos penales. op.cit. p.243.

${ }^{223}$ NIETO MARTín, Adán. Problemas fundamentales del cumplimiento normative en el derecho penal. In: KUHLEN, Lothar (ed.). MONTIEL, Juan Pablo (ed.). ORTIZ DE URBINA GIMENO, Iñigo (ed.). Compliance y teoria del derecho penal. Madrid: Marcial Pons, 2013. p. 30.

${ }^{224}$ SILVA, José Afonso. Curso de Direito Constitucional Positivo. 32 ed. ver. atual. São Paulo: Editora Malheiros, 2009. p. 786.

${ }^{225}$ COMPARATO, Fabio Konder. O Indispensável direito econômico. In: COMPARATO, Fabio Konder. Ensaios e pareceres de direito empresarial. Rio de Janeiro: Forense, 1978. p.457.

${ }^{226}$ COMPARATO, Fabio Konder. op.cit. p. 458.

${ }^{227}$ BERCOVICI, Gilberto. Política econômica e direito econômico. Revista da Faculdade de Direito (USP), v. 105,2010 . p. 397
} 
diretiva, com um programa de política econômica incorporado ao seu texto ${ }^{228} \mathrm{e}$, de acordo com o seu artigo 170, a ordem econômica será fundada na valorização do trabalho humano e na livre iniciativa, tendo por fim assegurar a todos existência digna, conforme os ditames da justiça social, observando-se princípios como a função social da propriedade, a livre concorrência, a defesa do consumidor e do meio ambiente.

O período de desregulamentação, especialmente na década de 80 , foi acompanhado de um desenvolvimento tecnológico que possibilitou maior integração e velocidade na circulação de informações ${ }^{229}$. Neste período, percebe Braithwaite que os Estados passaram a se preocupar mais com a regulação e menos com o fornecimento de serviços, fazendo com que regulações não estatais fossem desenvolvidas de forma mais rápida ${ }^{230}$. A ordem jurídica, então, forneceria normas de conduta que determinariam quando e de que forma os fatos econômicos seriam harmonizados e colocados em prática na sociedade ${ }^{231}$ criando, desta forma, um ambiente saudável para que a economia prospere ${ }^{232} \mathrm{e}$ dê base à política pública ao estabelecer os objetivos, controles e instrumentos adequados para garantir o bom funcionamento do sistema econômico ${ }^{233}$.

O mercado não deve ser visto como uma ordem espontânea, mas como uma estrutura social resultante de decisões políticas e jurídicas ${ }^{234}$ e que, diante da necessidade de alcançar um equilíbrio na economia, o Estado precisará assegurar a existência de condições que mantenham tal equilíbrio e funcionar como um redutor de $\operatorname{crises}^{235}$,

\footnotetext{
${ }^{228}$ BERCOVICI, Gilberto. op.cit. p. 403. O autor explica política econômica como o estudo das formas e efeitos da intervenção do Estado na vida econômica visando a atingir determinados fins.

${ }^{229}$ SARCEDO, Leandro. Compliance e Responsabilidade Penal da Pessoa Jurídica: Construção de um novo modelo de imputação, baseado na culpabilidade corporativa. Faculdade de Direito, Universidade de São Paulo, São Paulo, 2014.p.24.

${ }^{230}$ BRAITHWAITE, John. Regulatory capitalism: how it works, ideas for making it work better. Massachusetts: Edward Elgar Publishing: 2008. p.01.

${ }^{231}$ SICA, Leonardo. Tutela penal da ordem econômica no direito brasileiro: comparação entre as leis n.8137/90 e 8884/94. In: VILARDI, Celso Sanchez (org). PEREIRA, Flávia Rahal Bresser (org). DIAS NETO, Theodomiro. Direito Penal Econômico: Análise Contemporânea. São Paulo: Saraiva, 2009. p.146.

${ }^{232}$ CANTERJI, Rafael Braude; TANGERINO, Davi de Paiva Costa. Estado, economia e direito penal: o direito penal tributário no liberalismo, no welfare state e no neoliberalismo. In: TANGERINO, Davi de Paiva Costa; GARCIA, Denise Nunes (Coord.). Direito penal tributário. São Paulo: Quartier Latin, 2007. p.25.

${ }^{233}$ BERCOVICI, Gilberto. op.cit. p. 393. O autor define política econômica como "o estudo das formas e efeitos da intervenção do Estado na vida econômica visando a atingir determinados fins". BERCOVICI, Gilberto. Política econômica e direito econômico. Revista da Faculdade de Direito (USP), v. 105, 2010. p. 390.

${ }^{234}$ BERCOVICI, Gilberto. O Ainda Indispensável Direito Econômico. In: Maria Victoria de Mesquita Benevides; Gilberto Bercovici; Claudineu de Melo. (Org.). Direitos Humanos, Democracia e República: Homenagem a Fábio Konder Comparato. São Paulo: Quartier Latin, 2009. p. 504.

${ }^{235}$ COMPARATO, Fabio Konder. O Indispensável direito econômico. In: COMPARATO, Fabio Konder. Ensaios e pareceres de direito empresarial. Rio de Janeiro: Forense, 1978. p. 463.
} 
especialmente diante de exigências de entidades internacionais que passam a impor normas de reorientação econômica ${ }^{236}$.

O Estado intervir na economia implicaria no reconhecimento da incapacidade do mercado em distribuir, de forma igualitária, determinados bens e direitos considerados mínimos $^{237}$ e tal intervenção penal na ordem econômica aparece em leis especiais como a Lei n.1521/51, que traz os crimes contra a economia popular, o Código de Defesa do Consumidor (Lei n.8078/90), a Lei 8370/90, que dispõe sobre os crimes contra a ordem tributária, econômica e relações de consumo e a Lei n.7492/86 que tutela a ordem financeira $^{238}$.

Com a desregulamentação, as operações bastante rentáveis, no curto prazo, tornaram-se mais frequentes, assim como as notícias de fraudes que possuem como contexto manipulações contábeis e falta de transparência nas informações ${ }^{239}$. Tais práticas delituosas como a especulação comercial já foram criminalizadas desde o auge do Estado liberal, em que as crenças do livre mercado e dos ajustes da "mão invisível” eram fortemente defendidas ${ }^{240}$, e que transformaram o direito penal em um "mecanismo de direcionamento para a reformulação" das economias fragilizadas dos países centrais ${ }^{241}$.

Entretanto, os progressivos e constantes aumentos da complexidade econômicosocial, dos níveis de tecnicismo e desenvolvimento tecnológico, somados ao forte processo de globalização privaram o Estado de regular de forma adequada as estruturas empresariais $^{242}$, levando ao comprometimento dos domínios de regulação às grandes corporações que detinham maior capacidade técnica e conhecimento das atividades

\footnotetext{
${ }^{236}$ COMPARATO, Fabio Konder. op.cit. p. 459.

${ }^{237}$ CANTERJI, Rafael Braude; TANGERINO, Davi de Paiva Costa. Estado, economia e direito penal: o direito penal tributário no liberalismo, no welfare state e no neoliberalismo. In: TANGERINO, Davi de Paiva Costa; GARCIA, Denise Nunes (Coord.). Direito penal tributário. São Paulo: Quartier Latin, 2007. p.28.

${ }^{238}$ SICA, Leonardo. Tutela penal da ordem econômica no direito brasileiro: comparação entre as leis n.8137/90 e 8884/94. In: VILARDI, Celso Sanchez (org). PEREIRA, Flávia Rahal Bresser (org). DIAS NETO, Theodomiro. Direito Penal Econômico: Análise Contemporânea. São Paulo: Saraiva, 2009. p. 154.

${ }^{239}$ SARCEDO, Leandro. Compliance e Responsabilidade Penal da Pessoa Jurídica: Construção de um novo modelo de imputação, baseado na culpabilidade corporativa. Faculdade de Direito, Universidade de São Paulo, São Paulo, 2014.p.25.

${ }^{240}$ ROYSEN, Joyce. Histórico da criminalidade econômica. Revista Brasileira de Ciências Criminais, São Paulo, v. 11, 42 Esp, jan./mar. 2003. p. 193.

${ }^{241}$ ROYSEN, Joyce. op.cit. p. 193.

${ }^{242}$ COCA VILA, Ivó. ¿Programas de cumplimiento como forma de autorregulación regulada? In: MONTANER FERNÁNDEZ, Raquel (coord.). Criminalidad de empresa y compliance. Prevención y reacciones corporativas. Barcelona: Atelier, 2013. p.45.
} 
exercidas $^{243}$. O enfraquecimento da regulação, mostrado nos anos $80 \mathrm{com}$ a satírica frase "greed is good" evidenciou as assimetrias de informações criadas por um mercado sem controle e a necessidade de instituições regulatórias adequadas ${ }^{244}$.

No Brasil, explica Renato de Mello Jorge Silveira que a necessidade do uso de diversos instrumentos para a sedimentação da ordem econômica pareceria legitimar o amparo que faz o artigo 170, da Constituição Federal brasileira, a um reforço penal na economia $^{245}$. O professor, entretanto, critica o uso de teses de base econômica como, por exemplo, a teoria dos jogos, cujo pragmatismo entraria em conflito com a mensagem humanista do direito penal ${ }^{246}$.

Conforme explica Jesus Maria Silva Sánchez, a crescente importância do sistema financeiro na realidade globalizada atrai o direito penal como forma de responder a exigências do poder político e jurídico, impotentes na luta dos ordenamentos nacionais contra a criminalidade transnacional ${ }^{247}$. O autor define a globalização econômica como um “fenômeno em princípio econômico, determinado pela eliminação de restrições às transações comerciais e ampliação dos mercados ${ }^{248, "}$ e sua delinquência teria como principal objeto de estudo os delitos qualificados como "crimes of the powerful" ("crimes dos poderosos"), cuja regulação ainda não se encontra suficientemente assentada ${ }^{249}$.

Novas formas de criminalidade deslocaram a preocupação do direito penal para a proteção de bens jurídicos universais e $\operatorname{coletivos}^{250}$ e com a criminalização destes novos bens supraindividuais pretende-se proteger o correto e adequado funcionamento das empresas e do próprio mercado ${ }^{251}$. De acordo com Bernd Schünemann torna-se sem efeito

\footnotetext{
${ }^{243}$ BRAITHWAITE, John. Regulatory capitalism: how it works, ideas for making it work better. Massachusetts: Edward Elgar Publishing: 2008. p.25.

${ }^{244}$ BRAITHWAITE, John. op.cit. p.09-10.

${ }^{245}$ SILVEIRA, Renato de Mello Jorge. Considerações penais sobre o acordo de leniência na realidade antitruste. In: PASCHOAL, Janaína Conceição; SILVEIRA, Renato de Mello Jorge (Coord.). Livro homenagem a Miguel Reale Júnior. Rio de Janeiro: G/Z, 2014. p. 563.

${ }^{246}$ SILVEIRA, Renato de Mello Jorge. op.cit. p. 582.

${ }^{247}$ SILVA SÁNCHEZ, Jesús María. A expansão do direito penal: aspectos da política criminal nas sociedades pós-industriais. 3. ed. São Paulo: Revista dos Tribunais, 2013. p. 98.

${ }^{248}$ SILVA SÁNCHEZ, Jesús María. op.cit. p. 102.

${ }^{249}$ SILVA SÁNCHEZ, Jesús María. op.cit. p. 99.

${ }^{250}$ SICA, Leonardo. Tutela penal da ordem econômica no direito brasileiro: comparação entre as leis n.8137/90 e 8884/94. In: VILARDI, Celso Sanchez (org). PEREIRA, Flávia Rahal Bresser (org). DIAS NETO, Theodomiro. Direito Penal Econômico: Análise Contemporânea. São Paulo: Saraiva, 2009. p.149.

${ }^{251}$ SILVEIRA, Renato de Mello Jorge. Direito penal econômico como direito penal de perigo. São Paulo: Revista dos Tribunais, 2006. p. 26. Cumpre ressaltar a necessidade de observarem-se as características individuais de cada país, sem esquecer que os processos de governo não agem mais de forma independente, mas em um contexto supranacional. SILVEIRA, Renato de Mello Jorge. Direito penal econômico como
} 
um direito penal retrógrado que não acompanhe a criminalidade avançada e desenvolvida $^{252}$.

Para Klaus Tiedemann, o direito pode e deve ser utilizado na área econômica como forma de introduzir ordem e moralidade, tendo em vista que a problemática da criminalidade econômica afetaria diversos aspectos da ordem jurídica ${ }^{253}$. Entende o autor que o direito econômico ${ }^{254}$ não constitui uma categoria nova, mas agrega ao direito já existente um valor especificamente econômico, assim como se refere "à regulação das relações das empresas entre $\mathrm{si}^{255}$ ".

De forma contrária, Gilberto Bercovici e Luciano Anderson de Souza, entendem que a escolha político-econômica dentro de um Estado de Direito poderia levar a uma flexibilização de limites, devendo-se, portanto, respeitar o núcleo essencial do direito penal, ou seja, seu caráter de ultima ratio ${ }^{256}$. Afirmam, ainda, que não se pode admitir o uso da norma penal como forma de assegurar políticas econômicas ${ }^{257}$. Em um contexto de direito penal em um Estado Democrático de Direito, caberia a intervenção penal de forma bastante limitada, com o intuito de repelir os comportamentos insuportáveis à economia, evitando assim "a promoção de políticas econômicas ou o mero reforço a normas de cunho administrativo, abusando-se da função simbólica do direito penal ${ }^{258}$ ".

direito penal de perigo. São Paulo: Revista dos Tribunais, 2006. p.57. O conceito de empresa é definido por Klaus Tiedemann como "uma atividade empreendedora de produção, elaboração ou comercialização de produtos, assim como de prestação de serviços”. TIEDEMANN, Klaus. Manual de Derecho Penal Económico: parte general y especial. Valencia: Ed. Tirant lo Blanch, 2010. p.42.

${ }^{252}$ SCHÜNEMANN, Bernd. Del derecho penal de la clase baja al derecho penal de la clase alta: un cambio de paradigma como exigencia moral. In: SCHÜNEMANN, Bernd. Temas actuales y permanentes del derecho penal después del milenio. Madrid: Tecnos, 2002.p.68.

${ }^{253}$ TIEDEMANN, Klaus. La criminalidad económica como objeto de investigación. Cuadernos de política criminal, Madrid, n. 19, 1983.p.178-181.

${ }^{254}$ Para Tiedemann, o Direito econômico está formado pelo conjunto de normas jurídicas promulgadas para a regulação da produção, da fabricação e distribuição dos bens econômicos. TIEDEMANN, Klaus. Poder Económico y Delito. Barcelona: Ed. Ariel, 1985.p.19.

${ }^{255}$ TIEDEMANN, Klaus. El concepto de derecho económico, de derecho penal económico y de delito económico. Cuadernos de política criminal, Madrid, n. 28, 1986.p. 71.

${ }^{256}$ BERCOVICI, Gilberto; SOUZA, Luciano Anderson de. Intervencionismo econômico e direito penal mínimo: uma equação possível. In: OLIVEIRA, William Terra de; LEITE, NETO, Pedro Ferreira; ESSADO, Tiago Cintra; SAAD-DINIZ, Eduardo (orgs.). Direito penal econômico: estudos em homenagem aos 75 anos do Professor Klaus Tiedemann. São Paulo: LiberArs, 2013.p.22. Neste sentido, Kristian Kühl explica o princípio da subsidiariedade como um "postulado de política criminal dirigido ao legislador". KÜHL, Kristian. Direito penal fragmentário e subsidiário. In: OLIVEIRA, William Terra de; LEITE, NETO, Pedro Ferreira; ESSADO, Tiago Cintra; SAAD-DINIZ, Eduardo (orgs.). Direito penal economico: estudos em homenagem aos 75 anos do Professor Klaus Tiedemann. São Paulo: LiberArs, 2013.p.53 e ss.

${ }^{257}$ BERCOVICI, Gilberto; SOUZA, Luciano Anderson de. op.cit. p.23.

${ }^{258}$ BERCOVICI, Gilberto; SOUZA, Luciano Anderson de. op.cit. p. 24. 
Esta influência da economia no direito penal resultou nos sistemas de autorregulação, como forma do mercado prevenir-se de escândalos financeiros e econômicos, diante das falhas do direito penal em regular tal seara ${ }^{259}$. A regulação estatal "encara um problema de conteúdo", ao ter que acompanhar a rapidez com que são desenvolvidas evoluções técnicas em diferentes áreas empresariais ${ }^{260}$. Com as fraudes ocorridas nos anos 2000, evidenciou-se a somente aparente eficiência da autorregulação dos mercados e novos questionamentos sobre a "real e efetiva capacidade dos atores econômico-financeiros de se autorregularem e prevenirem a ocorrência de ilícitos", não apontando os riscos gerados e as fraudes no decorrer das atividades empresariais ${ }^{261}$.

Para Ivó Coca Vila, a autorregulação poderia ser dividia em três níveis: a autorregulação voluntária, na qual as empresas disporiam de autonomia e soberania suficientes para regular-se da maneira mais conveniente, sem nenhuma intervenção pública; na meta-regulação, o Estado condicionaria normas e incentivaria as empresas a se autorregularem, a partir de parâmetros mínimos, e, por último, a autorregulação regulada, caracterizada pela incorporação da empresa no processo de regulação, porém de forma subordinada a interesses pré-determinados pelo Estado ${ }^{262}$.

Carlos Gómez-Jara Díez estabelece que também três seriam os âmbitos da autorregulação no direito penal empresarial ${ }^{263}$. O primeiro seria "a cessão à empresa da soberania do castigo a seus funcionários", na qual há uma ruptura total com o ius puniendi estatal para executar a punição de condutas delitivas, diante do melhor conhecimento da estrutura empresarial. $\mathrm{O}$ autor, entretanto, não concorda com a substituição do contrato socioestatal pelo contrato empregado-empresa, considerando que, ainda que muitas empresas sejam mais poderosas, econômico e politicamente, que alguns Estados, não se justificaria uma substituição da soberania estatal.

\footnotetext{
${ }^{259}$ SILVEIRA, Renato de Mello Jorge; SAAD-DINIZ, Eduardo. Compliance, Direito Penal e Lei Anticorrupção. São Paulo: Saraiva, 2015. p. 212.

${ }^{260}$ BARBOSA, Julianna Nunes Targino. A culpabilidade na responsabilidade penal da pessoa jurídica. Faculdade de Direito, Universidade de São Paulo, São Paulo, 2014.p.33.

${ }^{261}$ SARCEDO, Leandro. Compliance e Responsabilidade Penal da Pessoa Jurídica: Construção de um novo modelo de imputação, baseado na culpabilidade corporativa. Faculdade de Direito, Universidade de São Paulo, São Paulo, 2014.p.28.

${ }^{262}$ COCA VILA, Ivó. ¿Programas de cumplimiento como forma de autorregulación regulada? In: MONTANER FERNÁNDEZ, Raquel (coord.). Criminalidad de empresa y compliance. Prevención y reacciones corporativas. Barcelona: Atelier, 2013.p.48-51.

${ }^{263}$ GÓMEZ-JARA DÍEZ, Carlos. Cuestiones fundamentales de derecho penal económico: parte general y parte especial. Bogotá: Universidad Externado de Colombia, 2012.p.41 e ss.
} 
O segundo âmbito seria a transferência a uma entidade privada da soberania da punição às empresas, no qual, entidades privadas seriam responsáveis pela supervisão de uma determinada atividade empresarial. Mais uma vez estaria reconhecida a incapacidade econômica e cognoscitiva do Estado em fazer frente à evolução experimentada pelas sociedades modernas ${ }^{264}$.

Por último, o autor traz a cessão à empresa de um âmbito da autorregulação em troca da responsabilidade pelas consequências que dela derivam. Para Gómez Jara-Díaz, este movimento teria uma vertente mais relevante na configuração do direito penal empresarial, sem prejudicar a soberania estatal ${ }^{265}$. Aqui, há o reconhecimento não só da conduta dos empregados da organização empresarial poderem questionar a vigência das normas do ordenamento jurídico estatal, mas a própria empresa também seria capaz ${ }^{266}$.

Os limites entre os códigos privados e públicos são explicados por Gunther Teubner. O autor explica que, muitas vezes, as regulamentações estatais são vistas como meras recomendações em áreas específicas que não chegam a trazer efeitos práticos. Entretanto, diante de suas particulares circunstâncias e da pressão social (ONGs, movimentos sociais, consumidores, sindicatos e também a opinião pública) as empresas desenvolvem de forma "voluntária" códigos e mecanismos internos ${ }^{267}$. Códigos estes que estabelecem regras limitadoras para as externalidades negativas das corporações e constitutivas para a autonomia corporativa. Determinam e regulam a implementação de procedimentos de tomadas de decisões e as fronteiras de suas atividades ${ }^{268}$.

Uma abordagem mais política é trazida por Manuel Maroto Calatayud que ressalta a existência de uma grande quantidade de atores privados, especialmente fortalecidos pela globalização, que exercem de maneira formal e informal funções de autoridade pública, com capacidade suficiente para determinar padrões de conduta e supervisioná-los. Entretanto, faltaria legitimidade política a estes grandes grupos empresariais. Com raízes em ideias desreguladoras, a autorregulação demonstraria a capacidade interna das empresas de conduzirem suas atividades sem interferências externas. Ao Estado caberia

\footnotetext{
${ }^{264}$ GÓMEZ-JARA DÍEZ, Carlos. op.cit. p.45.

${ }^{265}$ GÓMEZ-JARA DÍEZ, Carlos. op.cit. p.46.

${ }^{266}$ GÓMEZ-JARA DÍEZ, Carlos. op.cit. p.47.

${ }^{267}$ TEUBNER, Gunther. Self-constitutionalizing TNCs? On the linkage of "private" and "public" corporate codes of conduct. Indiana Journal of Global Legal Studies, vol.18, 2011.p.637.

${ }^{268}$ TEUBNER, Gunther. op.cit. p.624-625.
} 
estipular regras de responsabilidade e orientações pré-determinadas para balancear os interesses das empresas com os seus stakeholders ${ }^{269}$.

Ressalta Maroto Calatayud que a pretensa independência em relação às intervenções estatais é enfraquecida nos momentos de crise, nos quais a regulação excessiva ou falta dela é altamente questionada ${ }^{270}$. Outro fundamento seria explicado por argumentos tecnocráticos e pela noção de eficiência do próprio mercado em sua própria regulação, diante da qual o Estado estaria em uma posição de inferioridade em relação aos desenvolvimentos técnicos das empresas especializadas. Acompanhar os diferentes setores de produção demandaria um elevado custo econômico estatal, enquanto estimular uma autorregulação daqueles que possuem o conhecimento necessário para determinada área, seria um tipo de regulação low $\operatorname{cost}^{271}$.

Neste contexto de autorregulação conjunta entre o Estado e as empresas, a busca por parte das empresas de novas formas de organização pode ser entendida como uma estratégia de readaptação e não um real compromisso com o interesse público ${ }^{272}$. O uso do direito penal para evitar comportamentos considerados danosos e garantir o funcionamento do mercado encontra, desta forma, reforço nos novos padrões específicos de colaboração que exigem das empresas e instituições que repensem seus modelos de gestão e tomadas de decisão ${ }^{273}$.

Sem que seja necessário o enfraquecimento do Estado, deve-se buscar uma cooperação deste com os entes privados, cabendo ao primeiro "encontrar incentivos que combinem procedimentos empresarias de autorregulação com suas prestações de deveres de informação", que serão orientados, dentro das empresas, por preceitos estatais que

\footnotetext{
${ }^{269}$ Por exemplo, conseguiria as grandes multinacionais influenciar toda sua cadeia de produção através de regulações de seus contratos com fornecedores e com suas cadeias de abastecimento introduzir mecanismos de monitoração e sanção de violações legais. TEUBNER, Gunther. Self-constitutionalizing TNCs? On the linkage of "private" and "public" corporate codes of conduct. Indiana Journal of Global Legal Studies, vol.18, 2011.p.633.

${ }^{270}$ MAROTO CALATAYUD, Manuel. Liberalismo vs. Neocorporativismo: los discursos de la autorregulación como discursos legitimantes. In: ARROYO JIMÉNEZ, Luis (dir.); NIETO MARTÍN, Adán (dir.). Autorregulación y sanciones. Valladolid: Lex Nova, 2008.p.78-79.

${ }^{271}$ MAROTO CALATAYUD, Manuel. op.cit. p.85.

${ }^{272}$ MAROTO CALATAYUD, Manuel. op.cit. p. 90.

${ }^{273}$ SAAD-DINIZ, Eduardo. Fronteras del normativismo: a ejemplo de las funciones de la información en los programas de criminal compliance. Revista da Faculdade de Direito, v. 108, 2013. p.14.
} 
determinem uma "prudente fiscalização e cumprimento das recomendações de governança $^{274, "}$

A delinquência empresarial é marcada pela globalização, pela internacionalização do direito penal, pela necessidade de análise de novos elementos e estratégias políticocriminais $^{275}$. Diante de uma quebra das fronteiras nacionais que faz com que se busque uma uniformidade de tratamentos ${ }^{276}$, será exigida das empresas e dos Estados uma preocupação prévia, com ênfase nas práticas de prevenção e na cooperação entre público e privado, modificando o contexto social para que boas práticas sejam internalizadas pelos diversos atores sociais envolvidos, desenvolvendo um ambiente ético para a sociedade, suas instituições e para a economia.

\footnotetext{
${ }^{274}$ SAAD-DINIZ, Eduardo. Fronteras del normativismo: a ejemplo de las funciones de la información en los programas de criminal compliance. Revista da Faculdade de Direito, v. 108, 2013. p.24.

${ }^{275}$ TERRADILLOS BASOCO, Juan Maria. Concepto y método del derecho penal económico. In: ARROYO ZAPATERO, Luis (dir.). LASCANO, Carlos (dir.). NIETO MARTIN, Adán. Derecho penal de la empresa: del derecho penal economico del Estado social al derecho penal de la empresa globalizado. Buenos Aires: Ediar, 2012.p.101.

${ }^{276}$ SILVEIRA, Renato de Mello Jorge; SAAD-DINIZ, Eduardo. Compliance, Direito Penal e Lei Anticorrupção. São Paulo: Saraiva, 2015.p. 26-27.
} 


\section{MARCOS REGULATÓRIOS}

Regulações financeiras, ambientais e sociais representam o que John Braithwaite explica como capitalismo regulatório. Aqui, diferentemente das características neoliberais contrárias à regulação, este modelo de capitalismo é caracterizado pela hibridização entre a privatização do público e a publicitação do privado $^{277}$. A regulação econômica, entendida como um padrão de intervenção estatal no mercado foi criada como resposta às demandas pela correção de práticas que se mostravam ineficientes ou não equitativas ${ }^{278}$. Com o desenvolvimento da economia e sua crescente complexidade de técnicas e interesses econômicos, novas atividades legislativas foram e são produzidas com o intuito de regular e proteger a ordem econômica ${ }^{279}$.

A necessidade de superar falhas de mercado e os movimentos disruptivos que podem gerar externalidades negativas faz com que haja uma demanda pela regulação do sistema financeiro e econômico ${ }^{280}$, buscando estabelecer procedimentos que devem ser seguidos e sanções diante do descumprimento destes. O fato de a globalização propor modificações tanto na fase da criação do direito, como em sua aplicação, tornam necessários padrões de segurança jurídica na proteção de interesses determinados que serão buscados através dos marcos regulatórios ${ }^{281}$.

A regulação pode ser vista como uma forma de o governo facilitar o cenário para que seja tomada a decisão correta, ao invés de influenciar esta decisão ${ }^{282}$. Um dos seus objetivos é minimizar os efeitos dos riscos do mercado e criar condições igualitárias para os diferentes agentes, através de mecanismos de controle e supervisão que mantenham as

\footnotetext{
${ }^{277}$ BRAITHWAITE, John. Regulatory capitalism: how it works, ideas for making it work better. Massachusetts: Edward Elgar Publishing: 2008. p.08. Para o autor, o neoliberalismo significa, institucionalmente, privatizações, desregulamentação, também do comércio internacional e uma esfera pública enfraquecida.

${ }^{278}$ POSNER, Richard A. Teorias da Regulação Econômica. In: MATTOS, Paulo (coord.). PRADO, Mariana Mota (org.). ROCHA, Jean Paul Cabral Veiga da (org.). COUTINHO, Diogo R. (org.). OLIVA, Rafael (org.). Regulação Econômica e Democracia: o debate norte-americano. São Paulo: Ed. 34, 2004. p.50.

${ }^{279}$ TIEDEMANN, Klaus. Derecho penal económico: introducción y parte general. San José: Grijley, 2009. p. 22 .

${ }^{280}$ SALGADO, Lucia Helena (org). FIUZA, Eduardo (org). Marcos regulatórios no Brasil revendo o papel do Estado após a crise financeira. Rio de Janeiro: Ipea, 2010. p.11.

${ }^{281}$ NAVARRO DOLMESTCH, Roberto. Reconfiguración del sistema de fuentes del derecho penal y amenaza de crisis del principio de legalidad: la incorporación del derecho internacional convencional y el fenómeno de la globalización. In: FARALDO CABANA, Patricia. Nuevos retos del derecho penal en la era de la globalización. Valencia: Tirant lo Blanch, 2004. p.159.

${ }^{282}$ SALGADO, Lucia Helena (org). FIUZA, Eduardo (org). op.cit. p.47.
} 
operações financeiras e empresariais dentro dos limites para a economia não só local, mas internacional $^{283}$.

As falhas de mercado, caracterizadas como as externalidades (aqui entendidas como ação de um agente que influencia o bem-estar de outras pessoas que não participam diretamente de uma determinada ação), nas assimetrias de informações e no exercício de poder de mercado, foram dadas como justificativas para a intervenção do regulador ${ }^{284}$. Conforme explica Alberto Silva Franco, as crises são partes inerentes do sistema capitalista, que vê nas regulamentações uma barreira para sua busca por lucros e à liberdade dos mercados ${ }^{285}$.

A integração do mercado global e suas complexidades evidenciam a impossibilidade de prever quando, como e de que forma a nova crise financeira começará e, portanto, os reguladores precisam estar adequadamente preparados para que as empresas realizem suas atividades de acordo com a lei ${ }^{286}$. A "financeirização" do sistema, caracterizada como um mecanismo de restauração da rentabilidade do $\operatorname{capital}^{287}$, materializa-se com a expansão das bolhas especulativas e, por esta razão, a aplicação da lei deve estar presente nos mercados sempre, também nos momentos em que todos ganham e não há preocupação com os métodos utilizados, para que medidas populistas e desesperadas não gerem novas necessidades no futuro ${ }^{288}$.

De acordo com os padrões definidos pela OCDE para uma adequada regulação deve-se realizar uma Análise do Impacto Regulatório. Esta Análise (AIR) é necessária para medir os benefícios, custos e efeitos de novas regulações e assim construir uma estrutura para que esta regulação seja ponderada de forma racional. Uma das principais considerações que deve ser feita são os impactos econômicos das propostas de regulação $^{289}$. Com estas orientações, a OCDE busca garantir uma regulação que seja

\footnotetext{
${ }^{283}$ AMORIM, Thiago Navarro Mafra. Contingência de crises financeiras: um estudo sobre a evolução da regulação dos mercados e o risco das instituições financeiras no Brasil, 2011. p.15.

${ }^{284}$ RIBEIRO, Ivan César. Regulação financeira, poder no mercado e crise financeira. Tese (Doutorado em Direito Comercial) - Faculdade de Direito, Universidade de São Paulo, São Paulo, 2012. p.77.

${ }^{285}$ FRANCO, Alberto Silva. A crise financeira de 2008: cinco anos depois. Revista Brasileira de Ciências Criminais, São Paulo, v. 21, n. 103, jul./ago. 2013. p.133.

${ }^{286}$ WILLIANS, Mark T. Uncontrolled risk: the lessons of Lehman Brothers and how systemic risk can still bring down the world financial system. New York: McGraw-Hill, 2010. p.211.

${ }^{287}$ FRANCO, Alberto Silva. op.cit. p.140.

${ }^{288}$ BRAITHWAITE, John. Regulatory capitalism: how it works, ideas for making it work better. Massachusetts: Edward Elgar Publishing: 2008. p.40-41.

${ }^{289}$ OCDE: Building an Institutional Framework for Regulatory Impact Analysis (RIA): Guidance for policy makers, 2008. p.07.
} 
efetiva e eficiente. Nesta avaliação feita pelos reguladores, um importante elemento a ser considerado é a determinação das responsabilidades que serão alocadas nas diferentes agências regulatórias para enforcement e compliance das normas ${ }^{290}$.

Entendida como um documento ou relatório, a AIR deve ser vista também como um sistema ou processo que questiona as propostas regulatórias. O processo de análise deve envolver: a definição do contexto político e os objetivos que se busca através da delimitação da ação governamental; a identificação das opções regulamentadoras ou não que podem auxiliar no objetivo da proposta; a identificação e quantificação dos impactos, custos e benefícios; o desenvolvimento do enforcement e das estratégias de compliance de acordo com a eficiência e efetividade; o monitoramento dos mecanismos que vão avaliar a evolução da proposta, bem como realizar uma consulta pública que permita aos stakeholders daquele sistema a oportunidade de participar da tomada de decisões ${ }^{291}$.

Diante dos questionamentos sobre a necessidade de mais normas regulatórias, as análises de impacto mostram-se de grande valia especialmente em ambientes de extrema competitividade, cujas complexas atividades necessitem de regulação. A AIR pode ser utilizada para determinar o impacto das políticas e revelar possíveis ligações com outras regulações, analisando o mérito das decisões tomadas e o impacto que delas vão resultar ${ }^{292}$. Para a tomada de decisão, a OCDE estabeleceu uma lista de verificação a ser observada que estabelece que o governo deverá avaliar a natureza e a magnitude do problema, bem como as estruturas e os custos de implementação da nova regulação. Esta regulação deverá ser clara e precisa, o que demandará a participação das partes interessadas, como empresas afetadas e sindicatos, por exemplo ${ }^{293}$.

O desenvolvimento do mercado mundial e a interligação entre economias tornam necessária a criação de uma identidade própria deste mercado globalizado, crescendo a demanda por regulamentações internacionais, de convenções e organizações internacionais que tragam maior eficiência e flexibilidade a atividades empresariais que evoluem rapidamente ${ }^{294}$. Neste sentido, a participação de atores não-estatais podem participar da

\footnotetext{
${ }^{290}$ OCDE: Building an Institutional Framework for Regulatory Impact Analysis (RIA): Guidance for policy makers, 2008. p.14.

${ }^{291}$ OCDE. op.cit. p. 16 .

${ }^{292}$ OCDE. op.cit. p. 25 .

${ }^{293}$ OCDE: Reference checklist for regulatory decision-making. Disponível em: < https://www.oecd.org/gov/regulatory-policy/35220214.pdf>.

${ }^{294}$ BECK, Ulrich. O que é globalização? Equívocos do globalismo, respostas à globalização. São Paulo: Editora Paz e Terra, 1999. p.227.
} 
elaboração de instrumentos não-vinculativos que poderão ser exigidos mesmo dos estados não participantes ${ }^{295}$. Conforme traz Maíra Rocha Machado, "há muito já se diagnostica que as funções reguladoras dos Estados-Nação derivam e dependem dos imperativos formulados por organizações internacionais (FMI, OMC, Banco Mundial, etc.) e pelas empresas multinacionais dos Estados hegemônicos ${ }^{296}$,"

Christine Parker afirma que regimes regulatórios requerem que as organizações internalizem a responsabilidade por sua própria ética e regulação e, desta forma, consigam prevenir, detectar e corrigir brechas legais e regulatórias ${ }^{297}$. O fato de que bancos e grandes corporações influenciam e contribuem para as práticas corruptivas e suas consequências danosas os colocam em uma importante posição junto aos reguladores no controle de suas próprias ações, como as políticas de know your client, demandar a origem de fundos obscuros e manter adequadas políticas antifraude e anticorrupção ${ }^{298}$.

Considerando que a lei tem por objetivo um ambiente de negócios mais previsível, reforçando valores econômicos e éticos em um determinado arcabouço institucional ${ }^{299}$, o estudo de países com diferentes tradições jurídicas e político-criminais buscou traçar um panorama das regulações que buscam prevenir a má gestão nas corporações e que evidenciam a padronização dos modelos de prevenção.

Diante do enfraquecimento das fronteiras nacionais, da limitação do controle do Estado e da nova lógica de mercado impulsionada pela globalização, há uma pressão pela uniformidade das práticas a serem aplicadas também no contexto penal ${ }^{300}$. Contamos com uma grande variedade de normas, instrumentos legais e mecanismos de aplicação da lei em ordenamentos nacionais e no campo internacional, nas quais as normas de soft law desempenham um importante papel ${ }^{301}$.

\footnotetext{
${ }^{295}$ ROSE, Cecily. International anti-corruption norms: their creation and influence on domestic legal systems. Reino Unido: Oxford University Press, 2015. p.14.

${ }^{296}$ MACHADO, Maíra Rocha. Internacionalização do direito penal. Sāo Paulo: Edesp, 2004.p.18.

${ }^{297}$ PARKER, Christine. Is there a reliable way to evaluate organisational compliance programs? Disponível em: <http://www.aic.gov.au/media_library/conferences/regulation/parker.pdf $>$. Acesso em 15 de abril de 2015. p.01.

${ }^{298}$ ROSE, Cecily. op.cit. p.06.

${ }^{299}$ MACHADO FILHO, Cláudio Pinheiro. Responsabilidade social e governança o debate e as implicações: responsabilidade social, instituições, governança e reputação. São Paulo: Pioneira Thomson Learning, 2006. p.41.

${ }^{300}$ SILVEIRA, Renato de Mello Jorge; SAAD-DINIZ, Eduardo. Compliance, Direito Penal e Lei Anticorrupção. São Paulo: Saraiva, 2015. p.35 e ss.

${ }^{301}$ ROSE, Cecily. op.cit. p.14-15.
} 
Conforme explica Gunther Teubner, o processo de globalização implicaria uma desconstrução da hierarquia das normas legais ${ }^{302}$, na qual diversos atores sociais passam a produzir normas que serão internalizadas por ordenamentos nacionais ${ }^{303}$. As diretrizes e orientações criadas pela soft law possuem como características a maior facilidade de interpretação, a celeridade com que são conduzidas as negociações, a menor resistência para internalização e a margem para discussão nos Estados, que permitirá que sejam adaptadas às diferentes realidades ${ }^{304}$. Os instrumentos de soft law mostram-se importantes por produzirem efeitos práticos, inclusive jurídicos, e criarem expectativas de conduta e o comprometimento com os demais atores ${ }^{305}$.

Importantes agentes não estatais, como OCDE e Transparência Internacional, com suas recomendações, criam mecanismos que, de forma mais simplificada, introduzem discussões e normas em sistemas legais nacionais sem que seja necessário passar por todos os complicados processos legislativos ${ }^{306}$.

Em artigo sobre o impacto da aplicação das normas (enforcement), John Coffee $\mathrm{Jr}$ questiona se uma maior intensidade regulatória atrairia ou afastaria empresas do mercado norte-americano. Ele explica que os elevados padrões de transparência exigidos pela SEC contribuíram para a redução dos custos de agência, uma vez que aumentam o nível de fiscalização por parte de analistas, investidores e seguradores ${ }^{307}$. Para Coffee Jr, o problema em penalidades leves é que estas sejam absorvidas como "custos de negócios", não resultando em uma efetiva aplicação dos requisitos trazidos pelos marcos regulatórios por parte das empresas. O autor diferencia, ainda, as demandas de regulação entre países que adotam o sistema de common law e de civil law: no primeiro caso, haveria uma maior separação entre a propriedade e o controle, gerando problemas relacionados com os administradores e, no segundo caso, o autor cita a questão dos conflitos de interesses entre os acionistas controladores e minoritários ${ }^{308}$. Considerando que as ações no primeiro grupo tendem a ser mais secretas, pois para agirem em proveito próprio os administradores agiriam de forma reservada, caberia aos reguladores responder com ações de enforcement,

\footnotetext{
${ }^{302}$ TEUBNER, Gunther. Breaking frames: economic globalisation and the emergence of lex mercatoria.p.01.

${ }^{303}$ TEUBNER, Gunther. op.cit. p.10.

${ }^{304}$ ROSE, Cecily. International anti-corruption norms: their creation and influence on domestic legal systems. Reino Unido: Oxford University Press, 2015. p.20-23.

${ }^{305}$ MACHADO, Maíra Rocha. Internacionalização do direito penal. Sāo Paulo: Edesp, 2004. p.50.

${ }^{306}$ ROSE, Cecily. op.cit. p.23.

${ }^{307}$ COFFEE JR, John C. Law and the market: the impact of enforcement. Columbia Law and Economics, Working Paper n.304, mar. 2007. p.240 e ss.

${ }^{308}$ COFFEE JR, John C. op.cit. p.294 e ss.
} 
enquanto para os casos dos acionistas controladores seria melhor um direcionamento para restrições no direito societário, uma vez que não seria tão simples para eles liquidarem suas ações no mercado sem maiores explicações.

Após a promulgação das reformas e com a recuperação do mercado, as histórias de falhas de governança e fraudes contábeis começaram a fazer parte do passado e grandes empresas voltaram a reclamar dos altos custos e da irracionalidade das novas regulações ${ }^{309}$. Após bilionários resgates governamentais, novamente, o Estado tornou-se um intruso nas atividades empresariais. Instituições financeiras, ainda que sejam prejudicadas, hesitam em requerer novas regulações, mais fortes e mais aplicáveis, uma vez que estas mesmas normas poderão prejudicar suas atividades no futuro ${ }^{310}$.

O debate internacional sobre o problema da criminalidade econômica, que afeta tanto instituições públicas quanto corporações privadas indicam uma concentração, atualmente, no campo da prevenção, da governança corporativa e compliance, no lugar de privilegiar as medidas de caráter repressivo ${ }^{311}$. Os grandes escândalos financeiros demonstraram condutas antiéticas de administradores de empresas, mas também evidenciaram uma falha massiva das práticas de governança corporativa ${ }^{312}$.

Se o capitalismo regulatório gera a comercialização dos vícios e virtudes, é função do Estado educar a sociedade para agir de forma eficiente e de acordo com a justiça ${ }^{313}$. Desta forma, caberá às empresas traduzir o que dispõem as leis e adaptar as exigências às suas atividades. Sem o intuito de engessar a atividade empresarial, a regulação estabelece algumas exigências, como regras de disclosure de informações, capital adequado ao nível de risco e proteção aos acionistas e investidores, como forma de evitar riscos futuros ${ }^{314}$, como aqueles vivenciados no boom da internet e na crise de 2008.

\footnotetext{
${ }^{309}$ CLARK, Robert Charles. Corporate Governance changes in the wake of the Sarbanes-Oxley Act: a morality tale for policymakers too. Harvard Law and Economics Discussion, n.525, 2005.p.02.

${ }^{310}$ COFFEE JR, John C. Law and the market: the impact of enforcement. Columbia Law and Economics, Working Paper n.304, mar. 2007. p.298.

${ }^{311}$ WALKER, Gary E. (ed). CLARKE, Lindel D. (ed). op.cit. p.29.

${ }^{312}$ BURNS, Arthur F.; EDWARDS, Franklin R. U.S. Corporate Governance: what went wrong and can it be fixed?. Chicago, 2003. p.01.

${ }^{313}$ BRAITHWAITE, John. Regulatory capitalism: how it works, ideas for making it work better. Massachusetts: Edward Elgar Publishing: 2008. p.205.

${ }^{314}$ AMORIM, Thiago Navarro Mafra. Contingência de crises financeiras: um estudo sobre a evolução da regulação dos mercados e o risco das instituições financeiras no Brasil, 2011. p.15-16.
} 


\subsection{False Claims Act}

O False Claims Act trata-se de um estatuto federal que regulamenta as penalidades cíveis e criminais por cobranças falsas, "maquiamento" de preços de produtos ou declarações falsas de obrigações devidas ao governo.

Serão responsáveis, de acordo com o FCA, aqueles que se utilizem de informações fraudulentas (\$3279.a.1.B.), entreguem declarações falsas ao governo (\$3729.a.e.) ou façam uso de registros falsos para assim diminuir ou evitar suas obrigações a serem pagas ou enviadas ao governo (\$3279.a.1.G). O False Claims Act autoriza pessoas físicas e jurídicas, que possuam evidências de práticas de fraudes, a processar a outra parte infratora em nome do governo norte-americano. Será considerada "pessoa" para o FCA qualquer pessoa natural, sociedade, corporação, associação ou pessoa jurídica, incluindo qualquer Estado ou subdivisão dele (§3733.1.4).

Nas ações qui tam, o governo pode intervir e participar da ação e, caso resolva declinar desta, o requerente particular poderá prosseguir com ação (\$3730.3). As penas serão reduzidas caso a pessoa que tenha cometido a violação forneça informações importantes no prazo de 30 dias, portanto, cooperando com o governo (§3279.a.2). Será entendido que a pessoa tinha conhecimento da violação quando tenha consciência da falsidade ou demonstre negligência com a veracidade das informações (§3279.b.1.A).

O governo então poderá propor um acordo com o infrator diante de circunstâncias razoáveis, adequadas e justas (§3730.c.2.B). Da mesma forma, poderá, de forma alternativa, optar por procedimentos administrativos que resultem em penalidades cíveis (\$3730.c.5). Aquele enquadrado nas previsões do FCA será responsabilizado pelas penalidades que podem variar entre $\$ 5000$ e, não mais que, $\$ 10000$, conforme regulado pelo Federal Civil Penalties Inflation Adjustment Act, de 1990.

O False Claims Act trouxe importantes considerações a respeito da proteção aos whistleblowers (\$3730.h). De acordo com o Ato, nenhum funcionário poderá sofrer perseguições, ser demitido, ameaçado, suspenso ou hostilizado como retaliação a atos legais que tenham realizado. Caso alguma destas condutas seja realizada contra o funcionário, este receberá o dobro da quantia do salário retroativo com juros e compensações por quaisquer danos causados. O whistleblower pode chegar a receber $30 \%$ da quantia recuperada pelo governo nas ações de False Claims. 
Em setembro de 2015, o Departamento de Justiça dos EUA (DOJ) publicou um memorando no qual priorizou a responsabilidade individual por irregularidades cometidas no âmbito empresarial ${ }^{315}$. O Departamento explicita a importância de um enforcement efetivo da legislação criminal e civil como forma de proteger o sistema financeiro e, consequentemente, toda a sociedade.

O memorando entende que o combate às más condutas empresariais seria mais bem aplicado com a responsabilização dos indivíduos que realizem estas infrações, como forma de prevenir futuras atividades ilegais, incentivar mudanças no comportamento corporativo, garantindo que as partes sejam responsáveis por suas ações e promovendo a confiança pública. Após o estudo de recursos que poderiam facilitar e melhorar a identificação de indivíduos culpáveis nos crimes corporativos, o memorando trouxe seis passos que precisam ser observados durante as investigações: a) a obrigação das empresas em disponibilizar todos os fatos importantes relacionados aos indivíduos responsáveis pelas infrações, não importando o cargo ou a posição ocupada pelo acusado; b) estas condutas devem ser o foco principal das investigações desde o início; c) os advogados cíveis e criminais precisam manter uma rotina de comunicação; d) o DOJ não irá dispensar indivíduos culpáveis de responsabilidades cíveis e criminais, mesmo quando resolvido o caso com a corporação; e) o DOJ terá um plano claro relacionado aos casos individuais e f) realizar avaliações sobre a capacidade de pagar as multas dos indivíduos envolvidos nas irregularidades a partir dos resultados causados por suas ações e o interesse público envolvido.

O memorando mostra-se importante na aplicação do False Claims Act por evidenciar os esforços realizados pelo Departamento de Justiça para devolver o dinheiro aos cofres públicos, bem como prevenir a ocorrência de novas fraudes corporativas. Conforme publicado, no final de 2015, o DOJ conseguiu recuperar US\$3.5 bilhões em casos relacionados ao $\mathrm{FCA}^{316}$, principalmente com casos relacionados à indústria da saúde e com os contratos com o governo, por exemplo, de fornecimento de armas, roupas e acessórios militares. Desde 2009, o DOJ conseguiu recuperar cerca de $\$ 16.5$ bilhões de

\footnotetext{
${ }^{315}$ U.S. DEPARTMENT OF JUSTICE: Individual Accountability for Corporate Wrongdoing. Washington D.C., 09 de setembro de 2015. Disponível em: < https://www.justice.gov/dag/file/769036/download>. Acesso em 16 de maio de 2015.

${ }^{316}$ U.S. DEPARTMENT OF JUSTICE: Justice Department recovers over \$3.5 billion from False Claims Act cases in Fiscal Year 2015. Washington D.C, 03 de dezembro de 2015. Disponível em: < https://www.justice.gov/opa/pr/justice-department-recovers-over-35-billion-false-claims-act-cases-fiscalyear-2015>. Acesso em 16 de maio de 2015.
} 
dólares com fraudes no sistema de saúde. O foco na área da saúde fez com que o governo norte-americano criasse um grupo de trabalho especial conhecido como Health Care Fraud Prevention and Enforcement Action Team (HEAT), com o intuito de coordenar as ações criminais e cíveis de prevenção a fraudes. O relatório afirma que os prêmios pagos aos whistleblowers durante o ano de 2015, alcançaram o montante de \$597 milhões de dólares.

O Bipartisan Budget Act, de 2015, endureceu as penas do FCA em sua $\S 701$, que ficou conhecida como Federal Civil Penalties Inflation Adjustment Act Improvements Act. Com este Ato as agências federais poderão aumentar as sanções civis, oferecendo aos interessados a possibilidade de participação e debate sobre os custos e benefícios, até a versão final da regulação em agosto de 2016.

O False Claims Act representa uma poderosa ferramenta do governo para a recuperação de bilhões de dólares que poderiam ser perdidos em fraudes e falsas declarações prestadas por indivíduos e corporações em diversos setores e indústrias. Entretanto, a falta de clareza em suas disposições pode ocasionar problemas de proporcionalidade em suas sanções. Se uma empresa possuía a deliberada intenção de cometer a fraude ou se possuía mecanismos de prevenção que falharam em único momento deveria ser levado em consideração e previsto em lei. Conforme verificado, há um grande esforço para que haja uma maior participação dos whistleblowers e o foco na responsabilização individual como formas de prevenção à criminalidade. Esta excessiva confiança em delações, que nem sempre podem apresentar motivações corretas, não representa as mudanças necessárias em nível estrutural, assim como os acordos resolvem os problemas no curto prazo.

\subsection{FCPA (Foreign Corrupt Practices Act)}

O FCPA (Foreign Corrupt Practices Act) é um importante estatuto na prevenção à corrupção, cujos efeitos prejudicam expressivamente as instituições democráticas, ao desviar o dinheiro que, normalmente, seria utilizado para áreas importantes como a saúde, educação e infraestrutura ${ }^{317}$. Conforme analisa Nieto Martín, a responsabilização das

\footnotetext{
${ }^{317}$ HOUPT, Randell (ed.). The Foreign Corrupt Practices Act: a resource guide for businesses and individuals. New York: Nova Publishers, 2013. p.vii.
} 
empresas, tratada com mais atenção nos decorrer do trabalho, na luta contra a corrupção representa parte da recente política criminal, e o FCPA pode ser visto como a semente desta política $^{318}$.

Com o período de descolonização, países do terceiro mundo disponibilizavam um enorme espaço para que grandes empresas de países desenvolvidos expandissem suas atividades. Com uma estrutura empresarial e regulatória fraca, as grandes multinacionais utilizaram-se da corrupção para aproveitar destes novos mercados ${ }^{319}$. Ao agirem desta forma, estas empresas corruptoras realizaram condutas desleais que prejudicavam a atividade econômica, a alocação de recursos e frustraram a função social da concorrência $^{320}$.

O Congresso Americano promulgou o FCPA, em 1977, após as revelações do escândalo político do Watergate, e tornou crime pagar subornos para facilitar os negócios em países estrangeiros ${ }^{321}$, que tivessem por objetivo obter, reter ou direcionar um negócio $^{322}$. As investigações estavam ligadas às contribuições ilegais para a campanha de Richard Nixon e fizeram emergir a existência de fundos multimilionários utilizados para subornar autoridades estrangeiras em busca de contratos lucrativos ${ }^{323}$. Tais práticas, na visão do Congresso americano, prejudicavam a imagem das empresas americanas, a confiança em sua integridade financeira e na eficiência do mercado ${ }^{324}$. O FCPA teve, portanto, o objetivo de "eliminar o suborno de funcionários estrangeiros e restaurar a confiança do público na integridade do sistema empresarial dos EUA ${ }^{325 "}$.

O Ato foca em duas vertentes do problema da corrupção internacional: a primeira está relacionada com as cláusulas anti-suborno, que proibiram indivíduos e empresas de

\footnotetext{
${ }^{318}$ NIETO MARTÍN, Adán. La privatización de la lucha contra la corrupción. In: ARROYO ZAPATERO, Luis (dir.). NIETO MARTÍN, Adán (dir.). El derecho penal económico en la era compliance. Valência: Ed. Tirant lo Blanch, 2013.p.192.

${ }^{319}$ NIETO MARTÍN, Adán. La privatización de la lucha contra la corrupción. In: ARROYO ZAPATERO, Luis (dir.). NIETO MARTÍN, Adán (dir.). El derecho penal económico en la era compliance. Valência: Ed. Tirant lo Blanch, 2013.p.193-194.

${ }^{320}$ NIETO MARTÍN, Adán. op.cit. p.195.

${ }^{321}$ BIEGELMAN, Martin T; BIEGELMAN, Daniel R. Building a world-class compliance program: best practices and strategies for success. Hoboken, N.J.: John Wiley \& Sons, 2008.p.50.

${ }^{322}$ COIMBRA, Marcelo de Aguiar (org). MANZI, Vanessa Alessi (org). Manual de compliance preservando a boa governança e a integridade das organizações. São Paulo, Atlas, 2010.p.64.

${ }^{323}$ BIEGELMAN, Martin T; BIEGELMAN, Daniel R. Foreign corrupt practices act compliance guidebook: protecting your organization from bribery and corruption. Hoboken, N.J.: John Wiley \& Sons, 2010.p.08.

${ }^{324}$ HOUPT, Randell (ed.). op.cit.p.05.

${ }^{325}$ CARDOSO, Débora Motta. Greco Filho, Vicente. A extensão do compliance no direito penal análise crítica na perspectiva da lei de lavagem de dinheiro. São Paulo: Tese-USP, 2013.p.123.
} 
corromper oficiais estrangeiros, com o objetivo de manter ou conquistar novos negócios; e a segunda diz respeito à contabilidade, considerando a necessidade da empresa manter registros, evitar falsificações ou informações falsas no sistema ${ }^{326}$. Com estas determinações, o FCPA rompeu com a banalização das práticas corruptivas das empresas norte-americanas, ao aplicar proibições aos subornos e exigência de auditorias nas contas, para que a versão apresentada fosse a verdadeira, e não uma mais conveniente ${ }^{327}$.

As cláusulas anti-suborno do FCPA exigem que as empresas mantenham informações e documentos razoavelmente atualizados e certificados por contadores independentes $(\$ 78 \mathrm{~m} .1$ e $\S 78 \mathrm{~m} .2)$. É proibido que certos emissores de valores mobiliários façam "uso dos correios ou de qualquer meio ou organismo governamental de comércio interestadual, de forma corrupta, para promover uma oferta, pagamento, promessa de pagamento ou autorização de pagamento de qualquer soma em dinheiro, ou oferta, doação ou promessa de doação, ou ainda uma autorização de doação de qualquer item de valor" (§78dd-1.a.), com o fim de influenciar algum ato ou decisão, ou mesmo influenciar a qualquer dirigente, partido político estrangeiro ou candidato a cargo político estrangeiro; a qualquer pessoa, sabendo que toda ou parte de tal soma em dinheiro será direta ou indiretamente oferecido, doado ou prometido a um dirigente, candidato ou partido político (§78dd-2.a).

O programa mínimo proposto pelo FCPA envolve, entre outras medidas: padrões de compliance e práticas que devem ser seguidas pelos trabalhadores, consultores e diretores; a designação de altos funcionários para a supervisão do programa; a criação e manutenção de um comitê que fiscalize a contratação de agentes, consultores e outros representantes com quem se façam negócios em outros países; garantir que a função físcalizatória não fique sob a responsabilidade de indivíduos que se saiba, ou deva saber, estarem vinculados a práticas ilegais; assegurar as necessárias precauções para que a empresa só se envolva com indivíduos qualificados e estabelecer um sistema de denúncia que permita que práticas criminais sejam avisadas $^{328}$.

\footnotetext{
${ }^{326}$ HOUPT, Randell (ed.). op.cit. p.13.

${ }^{327}$ NIETO MARTÍN, Adán. La privatización de la lucha contra la corrupción. In: ARROYO ZAPATERO, Luis (dir.). NIETO MARTÍN, Adán (dir.). El derecho penal económico en la era compliance. Valencia: Ed. Tirant lo Blanch, 2013.p.199-200.

${ }^{328}$ BIEGELMAN, Martin T; BIEGELMAN, Daniel R. Building a world-class compliance program: best practices and strategies for success. Hoboken, N.J.: John Wiley \& Sons, 2008.p.118.
} 
Exige que as companhias não só abstenham-se dos pagamentos corruptos, mas também que implementem políticas e práticas que reduzam os riscos de funcionários e diretores serem atraídos por subornos ${ }^{329}$. O FCPA busca evitar que as mais diferentes práticas empresariais, de presentes a clientes até contribuições para caridade sejam utilizados como formas de mascarar condutas irregulares.

O Ato proporciona defesas para aqueles acusados por violações aos seus dispositivos, pois se o pagamento, presente ou oferta for lícito, de acordo com as leis e regulações do país estrangeiro, será considerada apropriada ${ }^{330}$. Desta forma, o FCPA estende seus efeitos aos envolvidos com práticas de corrupção dentro e fora do território americano $^{331}$. Esta disposição gerou grande preocupação para as grandes corporações norte-americanas que ficaram bastante preocupadas com a influência do FCPA em suas atividades, pois entenderam que ao cumprir com todas as suas exigências, estariam em desvantagem comercialmente em comparação com empresas estrangeiras ${ }^{332}$.

Os treinamentos contra corrupção deverão cobrir todas as exigências do FCPA: controles e auditorias internos e estratégias contra riscos de corrupção e subornos dentro da organização devem fazer parte do programa de compliance, com o objetivo de avaliar os consumidores, a natureza das operações, o histórico dos fracassos do compliance, o risco de fazer negócio com funcionários governamentais, empresas estatais, fornecedores, fusões e aquisições, lobistas e doações para caridade ${ }^{333}$.

Com suas cláusulas anti-suborno e a preocupação com a veracidade das informações disponibilizadas pelas empresas, o FCPA tem por objetivos estabelecer padrões de compliance e de boas práticas que permitam a implementação de um ambiente ético e honesto para as empresas, protegendo a integridade do mercado e reduzindo os efeitos negativos, para os Estados e para as empresas, das práticas ilegais relacionadas com a corrupção, dentro e fora dos Estados Unidos. Assim, a dificuldade do FCPA mostra-se evidente na regulação das práticas negociais realizadas em diversos países do mundo,

\footnotetext{
${ }^{329}$ BIEGELMAN, Martin T; BIEGELMAN, Daniel R. Foreign corrupt practices act compliance guidebook: protecting your organization from bribery and corruption. Hoboken, N.J.: John Wiley \& Sons, 2010.p.26.

${ }^{330}$ BIEGELMAN, Martin T; BIEGELMAN, Daniel R. Foreign corrupt practices act compliance guidebook: protecting your organization from bribery and corruption. Hoboken, N.J.: John Wiley \& Sons, 2010.p.30.

${ }^{331}$ CARDOSO, Débora Motta. Greco Filho, Vicente. A extensão do compliance no direito penal análise crítica na perspectiva da lei de lavagem de dinheiro. São Paulo: Tese-USP, 2013.p.127.

${ }^{332}$ ROSE, Cecily. International anti-corruption norms: their creation and influence on domestic legal systems. Reino Unido: Oxford University Press, 2015. p.64.

${ }^{333}$ BIEGELMAN, Martin T; BIEGELMAN, Daniel R. op.cit. p.255.
} 
tendo reduzido seu enforcement quando a empresa agir em países cuja regulação e vigilância não estejam tão aprimorados. A confiança em um esforço global de prevenção à corrupção não deve limitar-se aos países em desenvolvimento, mas também compreender a importância interna das corporações e suas influências, em âmbito nacional e internacional.

\subsection{Sarbanes-Oxley Act}

Com a simbólica frase do então presidente dos EUA, George Bush, "no more easy money for corporate criminals- just hard time", a lei Sarbanes-Oxley "estabeleceu novos deveres para os contadores e drásticas mudanças regulatórias em relação à governança corporativa $^{334,}$, reforçando os padrões para todas as companhias públicas norte-americana e firmas de contabilidade ${ }^{335}$. De acordo com Vania Maria da Costa Borgeth, o principal objetivo da lei foi "restaurar o equilíbrio dos mercados por meio de mecanismos que assegurem a responsabilidade da alta administração de uma empresa sobre a confiabilidade da informação por ela fornecida ${ }^{336}$ ".

Materializando o mercado como um bem jurídico, antecipou a tutela e criminalizou deveres administrativos impostos aos atores econômicos ${ }^{337}$. As penas, cominadas em patamares elevados, aumentaram o "preço do delito" e buscaram diminuir sua demanda, ao menos, nas transações que envolviam os EUA ${ }^{338}$. A medida mais importante da SOX foi adotar novas formas de restaurar a confiança pública nas corporações e no mercado de capitais $^{339}$, exigindo das empresas que internalizem os princípios éticos e estabeleçam boas práticas de governança corporativa, para que novas fraudes não aconteçam ${ }^{340}$.

Proibiu empresas de contabilidade de fornecerem serviços de consultoria além das auditorias dos balanços contábeis, uma vez que é importante que se fortaleça a confiança não só no mercado financeiro, mas também nos mecanismos de controle das atividades

\footnotetext{
${ }^{334}$ HEFENDEHL, Roland. Enron, WorldCom and the consequences: business criminal law between doctrinal requirements and the hopes of crime policy. Buffalo Criminal Law Review. Vol.8, n.1. Abril, 2004. p.51.

${ }^{335}$ REISINGER, Sue. Half-baked justice? Corporate prosecutions are all over the map. Janeiro, 2011.

${ }^{336}$ BORGERTH, Vania Maria da Costa. SOX: entendendo a Lei Sarbanes-Oxley - um caminho para a informação transparente. São Paulo: Cengage Learning, 2008.p.XVI.

${ }^{337}$ SILVEIRA, Renato de Mello Jorge; NETTO, Alamiro Velludo Salvador. Sarbanes-Oxley-act e os vícios do direito penal globalizado. Revista Ultima Ratio, Rio de Janeiro, v. 1, n. 0, 2006. p.202.

${ }^{338}$ SILVEIRA, Renato de Mello Jorge; NETTO, Alamiro Velludo Salvador. op.cit. p.205.

${ }^{339}$ CLARK, Robert Charles. Corporate Governance changes in the wake of the Sarbanes-Oxley Act: a morality tale for policymakers too. Harvard Law and Economics Discussion, n.525, 2005.p.03.

${ }^{340}$ BORGERTH, Vania Maria da Costa. op.cit. p.XVII.
} 
empresariais $^{341}$. Com o intuito de aprimorar a transparência e a confiabilidade nas informações, "passou ela a obrigar as empresas a verificar e descobrir, rapidamente, todas as irregularidades contábeis e bancárias, bem como crimes econômicos de maneira geral $^{342,}$.

A $§ 101$ estabelece a necessidade de um PCAOB (Public Company Accounting Oversight Board), um órgão regulador independente que avaliará e monitorará processos e firmas de auditoria. A função do PCAOB é "supervisionar o trabalho de auditoria das companhias abertas, de forma a proteger os interesses dos investidores e promover o interesse público na preparação de relatórios de auditoria que sejam informativos, precisos e independentes 343 ". A Seção 103 estabeleceu ao PCAOB "critérios para procedimentos de auditoria, controle de qualidade, ética e padrões de independência aplicados às empresas de auditoria registradas 344, . Poderá também o Conselho conduzir investigações sobre qualquer ato, prática ou omissão realizada por uma empresa de contabilidade associadas às empresas (Seção 105). Caso esta empresa não queria colaborar (recusar-se a testemunhar ou a entregar documentos, por exemplo), o PCAOB poderá suspender ou proibir a associação entre as empresas, revogar o registro da firma de contabilidade ou, ainda, escolher outras sanções apropriadas.

Os documentos que podem ser entregues para a fiscalização serão considerados confidencias e não serão utilizados como material de prova contra as empresas. Caso sejam confirmadas as irregularidades, o PCAOB poderá suspender temporária ou permanentemente o registro ou atividades da empresa ou as funções da pessoa responsável, bem como aplicar multas que variam de dez mil a quinze milhões de dólares.

A Seção 201 estabeleceu novas exigências aos auditores, proibindo a prestação de serviços não relacionados à auditoria como a guarda de livros, a implementação de sistemas de informação financeira, participações em relatórios do valor econômico, serviços de auditoria interna, recursos humanos, serviços legais ou funções $\operatorname{administrativas~}^{345}$. Todas as informações deverão ser divulgadas aos investidores em

\footnotetext{
${ }^{341}$ HEFENDEHL, Roland. op.cit. p.80.

${ }^{342}$ SILVEIRA, Renato de Mello Jorge; SAAD-DINIZ, Eduardo. Criminal compliance: os limites da cooperação normativa quanto à lavagem de dinheiro. Revista peruana de ciencias penales, Lima, n. 25, 2013. p.594.

${ }^{343}$ BORGERTH, Vania Maria da Costa. SOX: entendendo a Lei Sarbanes-Oxley - um caminho para a informação transparente. São Paulo: Cengage Learning, 2008.p.20.

${ }^{344}$ BORGERTH, Vania Maria da Costa. op.cit. p. 21.

${ }^{345}$ BORGERTH, Vania Maria da Costa. op.cit. p.24-25.
} 
relatórios periódicos. Esta seção, entretanto, não exigiu uma mudança nos responsáveis pela contabilidade e não trouxe responsabilizações para os gatekeepers relacionados às fraudes, intermediários estes que sabidamente ajudaram e incentivaram as condutas ilegais $^{346}$. A SOX determinou, em sua $\S 203$, que auditores e auditados devem ter poucos vínculos que não as práticas de auditoria, reduzindo a ligação e possíveis conflitos de interesses $(\S 206)$.

As mudanças pós-SOX podem ser agrupadas em três tópicos: 1) mudanças relacionadas à auditoria; 2) aos Conselhos e 3) regras de transparência e contabilidade ${ }^{347}$. Em sua seção §201, ficou proibido que auditores externos pudessem desempenhar serviços que não fossem de auditoria para seus clientes como, por exemplo, ajudar os clientes a operar softwares de contabilidade. A $§ 301$ determina que as empresas precisam contar com um Comitê de Auditoria autônomo formado por membros independentes que não serão influenciados por interesses internos.

A $\S 302$ vincula as publicações financeiras realizadas pela empresa à certificação do CEO e do CFO, disponibilizando assim informações mais confiáveis aos acionistas e ao mercado. Mais uma vez, ainda que estas ações demandem mais tempo e custos, estes parecem mais modestos que o trabalho e dinheiro envolvidos nos casos que envolvam fraudes $^{348}$. Esta seção exige que o administrador signatário tenha efetivamente revisado e analisado o relatório e ateste que este não contém nenhuma declaração falsa, nem omite informação relevante sobre as operações e resultados no período apresentado. Apostando na função de "porrete" do direito penal, pode-se observar, conforme afirma Renato Silveira, uma "instrumentalização do sistema repressor no sentido de manter os agentes econômicos a expectativa de veracidade acerca das notícias contábeis veiculadas pelas mais diversas empresas ${ }^{349}$,.

A influência negativa na realização das auditorias foi proibida pela §303, tendo sido considerado ilegal que o representante atrapalhe, manipule, tente coagir, enganar ou prejudicar as atividades do auditor. Com relação aos representantes legais, determinou a

\footnotetext{
${ }^{346}$ COFFEE JR, John C. What caused Enron? 20 de janeiro de 2003. Columbia Law \& Economics Working Paper n. 214. p.43.

${ }^{347}$ CLARK, Robert Charles. Corporate Governance changes in the wake of the Sarbanes-Oxley Act: a morality tale for policymakers too. Harvard Law and Economics Discussion, n.525, 2005.p.05 e ss.

${ }^{348}$ CLARK, Robert Charles. Corporate Governance changes in the wake of the Sarbanes-Oxley Act: a morality tale for policymakers too. Harvard Law and Economics Discussion, n.525, 2005.p.23.

${ }^{349}$ SILVEIRA, Renato de Mello Jorge; SAAD-DINIZ, Eduardo. Compliance, Direito Penal e Lei Anticorrupção. São Paulo: Saraiva, 2015. p.248.
} 
§307, que poderá ser solicitado ao advogado que apresente evidências de uma violação da lei dos valores mobiliários ou da quebra do dever fiduciário. Mais uma vez a delicada situação dos advogados aparece com uma possível renúncia à proteção dos segredos da profissão em determinadas situações como forma de comprometimento com as investigações, embora não tenham as garantias dos whistleblowers, por exemplo ${ }^{350}$.

Sobre a divulgação de demonstrações contábeis, a §401 dispõe que todas “deverão refletir correções materiais que tenham sido apontadas como necessárias pelos auditores independentes da companhia, e devem estar de acordo com os princípios contábeis geralmente aceitos e com demais regulamentos da $\mathrm{SEC}^{351}$ ". Para evitar novas fraudes como a da Enron, a SOX determinou que as empresas divulgassem a extensão das operações que não apareçam nos balanços, seus ativos, passivos, perdas, arrendamentos e o uso das entidades especiais (special purpose entities). Se um ou mais de seus diretores possuírem mais do que $10 \%$ do capital da empresa, deverá manter um cadastro atualizado na SEC (seção 403).

Adicionada à legislação após o caso WorldCom, a $\$ 404$ requer que as empresas desenvolvam e implementem processos de controle interno, com o objetivo de verificar os números, realizar divulgações transparentes e aperfeiçoar os sistemas de acesso às informações financeiras. Sobre os relatórios financeiros, o $\$ 302$ exige que sejam feitos de forma diligente, trimestre e anualmente, e que divulguem os resultados de uma forma justa e completa. É considerada a seção mais controversa, correspondendo pela maior parte dos custos da implementação da SOX. Tais custos foram alvo de críticas: no custo prazo, afetaram a competitividade das empresas que atenderam os padrões de compliance nas bolsas de valores; elevou-se preço dos serviços das empresas de auditoria, em torno de 20 $40 \%$ e as seguradoras aumentaram o prêmio do seguro para diretores e administradores de empresas $^{352}$.

Alguns custos são ocasionais como, por exemplo, o recrutamento de novos diretores independentes, mas outros realmente seguem contínuos, como os valores gastos com as sessões executivas regulares que precisarão ser realizadas. Porém, pode-se criticar

\footnotetext{
${ }^{350}$ HEMPHILL, Thomas A.; CULLARI, Francine. Corporate governance practices: a proposed policy incentive regime to facilitate internal investigations and self-reporting of criminal activities. Journal of Business Ethics, vol.87, supplement 1, Abril de 2009. p.342-343.

${ }^{351}$ BORGERTH, Vania Maria da Costa. SOX: entendendo a Lei Sarbanes-Oxley - um caminho para a informação transparente. São Paulo: Cengage Learning, 2008.p.35.

${ }^{352}$ SCARROW, Devin. Understanding the Sarbanes-Oxley Act and its impact. Harvard Business Review. Setembro, 2009. p.07-08.
} 
o fato de que os custos de implementação da $§ 404$ foram extremamente mais elevados do que o planejado pelos reguladores, o que gerou uma disparidade entre os gastos proporcionais das grandes empresas (cerca de $0,53 \%$ ) e das pequenas $(2,55 \%)^{353}$.

Sobre as novas práticas de contabilidade e transparência, a SOX entendeu que mais e melhores informações seriam de grande utilidade para que os investidores pudessem tomar melhores decisões e também para que fraudes possam ser evitadas. Uma das exigências é que operações extrapatrimoniais, como nos casos das special purpose entities, sejam divulgadas. Divulgado também deve ser as certidões referentes aos sistemas internos de controle e as auditorias externas realizadas na avaliação deles ${ }^{354}$. Em relação à contabilidade, buscou-se com a lei Sarbanes-Oxley reconhecer o seu valor como "provedora de informações" e "garantir ao usuário dessa informação a confiabilidade que jamais lhe deveria ter sido tirada" 355 .

Os códigos de ética deverão ser divulgados e disponibilizados no site da empresa, para que os seus stakeholders tomem ciência dos esforços e motivações internos para agir de acordo com a lei (§406). Assim que ocorrer um fato relevante, "a empresa deverá imediatamente divulgá-lo, evidenciando seu impacto sobre a situação financeira da empresa $^{356,}$.

Em relação aos Conselhos de Administração, a SOX buscou reduzir os conflitos de interesse que pressões pessoais poderiam causar em seus integrantes. Desta forma, os membros, em sua maioria independente, do Conselho tomarão as decisões em nome dos acionistas. Adicionalmente, será melhor que os membros tenham conhecimento na área financeira, pois desta forma poderão realizar mais questionamentos e políticas errôneas de contabilidade serão detectadas com mais facilidade.

A responsabilidade por fraudes criminais e corporativas foi tratada na $§ 801$. Dentre os crimes passíveis de punição estão a "destruição, alteração ou falsificação de registros em investigações federais e processos de falência"; a "destruição de arquivos de auditoria corporativa" e "obrigações não descartáveis se ocorridas em violações de leis de valores

\footnotetext{
${ }^{353}$ CLARK, Robert Charles. Corporate Governance changes in the wake of the Sarbanes-Oxley Act: a morality tale for policymakers too. Harvard Law and Economics Discussion, n.525, 2005.p.29.

${ }^{354}$ CLARK, Robert Charles. Corporate Governance changes in the wake of the Sarbanes-Oxley Act: a morality tale for policymakers too. Harvard Law and Economics Discussion, n.525, 2005.p.28.

${ }^{355}$ BORGERTH, Vania Maria da Costa. SOX: entendendo a Lei Sarbanes-Oxley - um caminho para a informação transparente. São Paulo: Cengage Learning, 2008.p.50.

${ }^{356}$ BORGERTH, Vania Maria da Costa. op.cit. p.41.
} 
mobiliários”. A $§ 802$ determinou penalidades com multas ou até vinte anos de prisão para o funcionário que alterar destruir ou falsificar documentos e arquivos com o objetivo de obstruir, impedir ou influenciar as investigações legais. Importante nos programas de controles internos, os whistleblowers foram protegidos pela $\S 806$, segundo a qual não poderão sofrer ameaças, assédios, rebaixamento, demissões ou qualquer outra forma de discriminação.

A $\S 902$ trouxe melhorias às sanções dos crimes de colarinho branco. Será punida qualquer pessoa que tentar ou conspirar para o cometimento de infrações ou cometer fraudes postais ou por transferência (§903). A empresa poderá ser responsabilizada pelos relatórios financeiros divulgados se faltarem requisitos exigidos (§906).

A Sarbanes-Oxley aumentou a responsabilidade dos administradores e membros do Conselho, em suas decisões e informações divulgadas. Estabeleceu ainda exigências para a conduta do CEO e da alta administração da empresa, incluindo sanções penais com até dez anos de prisão, por estar ciente da certificação financeira imprecisa ${ }^{357}$. Aumentou também o uso de auditores, contadores e advogados externos, porém estes novos custos são compensados pelas novas informações, antes não disponíveis para a melhor gestão da empresa $^{358}$.

A Lei Sarbanes-Oxley criou quatro novos crimes que abordaram as fraudes financeiras, ao mesmo tempo em que coordenou uma revisão das diretrizes existentes na U.S. Sentencing Comission em relação aos crimes de colarinho branco. Os novos tipos penais foram ${ }^{359}$ : sabidamente alterar, destruir, ocultar ou mesmo falsificar documentos, registros ou objetos com o intuito de impedir, obstruir ou influenciar investigações (18 U.S.C. §1519); sabidamente, com o intuito de retaliar, realizar ações prejudiciais que possam interferir em empregos ou meios de subsistência, por ter este funcionário fornecido informações sobre o cometimento de crimes ou infrações às autoridades (18 U.S.C. $\S 1513 \mathrm{e})$; falhas na certificação de relatórios financeiros por parte dos dirigentes corporativos (18 U.S.C. §1350), segundo o qual um representante poderá ser preso por não

\footnotetext{
${ }^{357}$ FERGUNSON, Charles H. O sequestro da América: como as corporações financeiras corromperam os Estados Unidos. Rio de Janeiro: Jorge Zahar Editor Ltda, 2012.p.215.

${ }^{358}$ HOLMSTROM, Bengt; KAPLAN, Steven N. The State of U.S. Corporate Governance: what's right and what's wrong. Finance Working Paper, n.23, 2003.p.21.

${ }^{359}$ BUCY, Pamela H. Carrots and Sticks: Post-Enron regulatory initiatives. Buffalo Criminal Law Review. Vol.08. n.1, abril. 2004.p.282-288.
} 
revelar ou divulgar problemas financeiros; e penalidades por enganar acionistas de companhias cujos títulos sejam negociados publicamente (18 U.S.C. §1348).

Roland Hefendehl explica que a Sarbanes-Oxley não é um mecanismo efetivo de governança corporativa porque falhou em três importantes áreas: na separação das funções entre o dirigente (CEO) e o conselho dos diretores; na limitação da emissão de ações e na reforma da regulamentação dos balanços contábeis ${ }^{360}$. Também três são as faltas normativas apontadas por John Coffee Jr: o fato de que deveria ter aumentado a responsabilidade civil pelo consentimento em fraudes administrativas; a redução de incentivos prejudiciais causados pelas opções sobre ações e, da mesma forma, deveria ter abordado os conflitos estruturais nos Conselhos que causam o "comportamento de rebanho" e análises tendenciosas ${ }^{361}$. Outras críticas envolvem a falta de alocação de poderes entre dirigentes, diretores e acionistas não foi modificada, assim como as regras referentes às grandes transações, que deveriam priorizar os melhores benefícios para os acionistas, não foram mencionadas ${ }^{362}$.

Após as graves fraudes do começo dos anos 2000, Enron e WorldCom, havia a necessidade por uma regulamentação que restaurasse o equilíbrio e a confiança no mercado e em suas instituições. Buscou-se por meio dos programas de compliance e governança impedir que fosse possível a falta de transparência avalizada por empresas de consultoria e auditorias. As informações prestadas passam a necessitar de certificação e os programas preventivos aplicados deverão ser monitorados e avaliados constantemente. A participação decisiva dos Conselhos continuou negligenciada, não dispondo sobre as características dos seus membros, o tempo em que poderiam fazer parte, nem sobre sua necessária autonomia. Os custos de implementação de todo os dispositivos exigidos pela SOX também poderiam prejudicar empresas menores, que teriam a obrigação de acompanhar a evolução dos programas das grandes corporações, sem as garantias de que a avaliação do Estado seria feita de forma proporcional.

\footnotetext{
${ }^{360}$ HEFENDEHL, Roland. op.cit.p. 58 .

${ }^{361}$ COFFEE JR, John C. What caused Enron? 20 de janeiro de 2003. Columbia Law \& Economics Working Paper n. 214. p.44.

${ }^{362}$ CLARK, Robert Charles. Corporate Governance changes in the wake of the Sarbanes-Oxley Act: a morality tale for policymakers too. Harvard Law and Economics Discussion, n.525, 2005.p.26.
} 


\subsection{Dodd-Frank Wall Street Reform and Consumer Act}

Em julho de 2010, foi promulgada a norma federal Dodd-Frank Wall Street Reform and Consumer Act com o objetivo de realizar uma reforma na regulação financeira dos EUA. Seus principais pontos envolveram o fim dos custosos resgates financeiros realizados pelo governo às grandes corporações consideradas too big to fail, e o estabelecimento de novos padrões de supervisão e vigilância das instituições financeiras. As reformas introduzidas buscaram evitar uma nova crise e, também, proteger os consumidores de sistemas financeiros ${ }^{363}$. A grave financeira ampliou o clamor por mais regulação e "mesmo os mais céticos em relação aos seus benefícios reconheceram a necessidade controles adicionais ${ }^{364,}$.

Entendeu-se que os marcos regulatórios encontravam-se defasados e que eram ineficientes no que se referia à supervisão do sistema financeiro e suas complexas operações $^{365}$. Após os graves resultados de 2008, a ideia dos reguladores era também reduzir os subsídios que distorciam o mercado ${ }^{366}$. Valendo-se da regulação existente e da atuação do governo, caracterizada pelos bilionários bailouts, os agentes agiam com o intuito de aumentar o seu poder de mercado, assumindo comportamentos de riscos excessivos, prejudiciais a todo sistema ${ }^{367}$.

A norma ressalta a importância do desenvolvimento de um mercado baseado na estabilidade econômica e financeira e na garantia de uma maior transparência nas atividades de suas entidades ${ }^{368}$. Após a crise, os investidores haviam perdido a confiança nos administradores de empresas e fundos e era necessária uma regulamentação que garantisse a identificação e avaliação dos riscos aos quais toda a sociedade estava exposta, bem como exigir transparência das instituições financeiras em seus balanços e relatórios. Foram determinadas recomendações de curto (como um maior controle para evitar práticas

\footnotetext{
${ }^{363}$ GONZÁLEZ DE LEÓN BERINI, Arturo. El criminal compliance en la reforma norteamericana de la Dodd-Frank Act. In: MONTANER FERNÁNDEZ, Raquel (coord.). Criminalidad de empresa y compliance. Prevención y reacciones corporativas. Barcelona: Atelier, 2013.p.132.

${ }^{364}$ RIBEIRO, Ivan César. Regulação financeira, poder no mercado e crise financeira. Tese (Doutorado em Direito Comercial) - Faculdade de Direito, Universidade de São Paulo, São Paulo, 2012. p.71.

${ }^{365}$ MATTOS, Eduardo da Silva. O que a crise do subprime ensinou ao Direito? Tese (Doutorado em Direito Comercial) - Faculdade de Direito, Universidade de São Paulo, São Paulo, 2014. p.79.

${ }^{366}$ MATTOS, Eduardo da Silva. op.cit. p.78.

${ }^{367}$ RIBEIRO, Ivan César. Regulação financeira, poder no mercado e crise financeira. Tese (Doutorado em Direito Comercial) - Faculdade de Direito, Universidade de São Paulo, São Paulo, 2012. p.23.

${ }^{368}$ GONZÁLEZ DE LEÓN BERINI, Arturo. El criminal compliance en la reforma norteamericana de la Dodd-Frank Act. In: MONTANER FERNÁNDEZ, Raquel (coord.). Criminalidad de empresa y compliance. Prevención y reacciones corporativas. Barcelona: Atelier, 2013.p.132-133.
} 
especulativas), médio (relacionadas às questões operacionais e estruturas de regulação) e longo prazo (focadas na obtenção de um sistema financeiro equilibrado) ${ }^{369}$.

A Dodd-Frank trouxe uma série de previsões normativas relacionadas às questões de autorregulação do sistema financeiro, com um conjunto de medidas adequadas ao controle e supervisão dos produtos financeiros arriscados ${ }^{370}$. Como forma de ajudar estas funções de controle, a lei incentiva que funcionários das empresas denunciem qualquer irregularidade de que tomem conhecimento diretamente às autoridades competentes, não sendo necessário informar previamente os canais internos de denúncia. Os whistleblowers, que serão explicados de forma mais detalhada a seguir neste trabalho, possuem para a Dodd-Frank um "papel chave na hora de detectar e prevenir as condutas corporativas fraudulentas ou ilícitas ${ }^{371}$ ". Por esta razão, a lei pune com bastante severidade qualquer ameaça ou discriminação ao funcionário denunciante, e prevê ao whistleblower até $30 \%$ da quantia recuperada $^{372}$.

A lei também exige que "toda agência de análise de risco deverá instituir, manter e documentar periodicamente uma estrutura interna eficaz de controle do cumprimento da norma legal", além de apresentar um informe "elaborado por uma entidade independente com relação aos produtos financeiros de risco que façam parte de suas atividades ${ }^{373 "}$. A complexidade destes produtos também foi alvo de regulamentação pela Dodd-Frank uma vez que, conforme analisado no caso Lehman Brothers, muitos investidores não sabiam os riscos que corriam ao investir em determinados papéis, não havendo, da mesma forma, avaliações fundamentadas e fiscalização por parte das agências de rating e das autoridades responsáveis.

Em sua seção 717, a Dodd-Frank tornou mais rígida e determinou novos padrões, mais completos, para a aprovação de novos produtos financeiros ${ }^{374}$. A Seção 1036 proíbe o oferecimento de produtos financeiros que não estejam em conformidade com a legislação financeira ou que violem suas disposições. Da mesma forma, será considerado ilegal

\footnotetext{
${ }^{369}$ MATTOS, Eduardo da Silva. op.cit. p.80.

${ }^{370}$ GONZÁLEZ DE LEÓN BERINI, Arturo. op.cit. p.136.

${ }^{371}$ GONZÁLEZ DE LEÓN BERINI, Arturo. El criminal compliance en la reforma norteamericana de la Dodd-Frank Act. In: MONTANER FERNÁNDEZ, Raquel (coord.). Criminalidad de empresa y compliance. Prevención y reacciones corporativas. Barcelona: Atelier, 2013.p.138.

${ }^{372}$ CARDOSO, Débora Motta. Greco Filho, Vicente. A extensão do compliance no direito penal análise crítica na perspectiva da lei de lavagem de dinheiro. São Paulo: Tese-USP, 2013. p.67.

${ }^{373}$ GONZÁLEZ DE LEÓN BERINI, Arturo. op.cit. p.140-141.

${ }^{374}$ MATTOS, Eduardo da Silva. O que a crise do subprime ensinou ao Direito? Tese (Doutorado em Direito Comercial) - Faculdade de Direito, Universidade de São Paulo, São Paulo, 2014. p.86.
} 
participar de atos ou práticas abusivas, injustas ou enganosas. Cumpre ressaltar que a alta dinamicidade do mercado e do ambiente de tomada de decisões faz com que novos desafios estejam sejam presentes à atividade do regulador ${ }^{375}$.

A remuneração do CEO e de outros altos executivos será submetida ao voto dos acionistas regularmente. Aos acionistas também serão divulgadas as informações importantes da empresa, de acordo com o estabelecido pela SEC e por acordos internos, para que seja possível uma decisão fundamentada em relação a fusões e aquisições ${ }^{376}$. Em relação aos bônus pagos aos administradores, a seção 953 estabeleceu que deverá ser disponibilizada aos acionistas descrição detalhada das remunerações feitas aos administradores. Também será divulgada a média dos salários pagos aos funcionários e a relação destes pagamentos com os números e resultados apresentados pela empresa ou instituição financeira.

Foi criado um órgão responsável pela proteção de investidores e consumidores de produtos financeiros chamado de Consumer Financial Protection Bureau, um órgão ligado ao Departamento do Tesouro que tem como função "a informação dos consumidores e investidores sobre produtos, instituições financeiras e educação quanto a possíveis $\operatorname{abusos}^{377,}$.

Promulgado após a crise de 2008, a Dodd-Frank busca melhorar a transparência nos mercado financeiro e aperfeiçoar seu monitoramento para que grandes empresas e instituições financeiras não possam, novamente, colocar todo o mercado em risco ${ }^{378}$. Foi entendido que seria necessária uma análise macroeconômica do sistema financeiro, "por meio de um conjunto mais pesado de compartilhamento de informações entre agências e de coordenação de ações anticíclicas que captasse com mais profundida a complexidade da intermediação financeira ${ }^{379,}$,

O enorme tamanho de algumas instituições financeiras também foi um fator considerado pela Dodd-Frank. A legislação trouxe limitações à concentração no setor

\footnotetext{
${ }^{375}$ RIBEIRO, Ivan César. Regulação financeira, poder no mercado e crise financeira. Tese (Doutorado em Direito Comercial) - Faculdade de Direito, Universidade de São Paulo, São Paulo, 2012. p.73.

${ }^{376}$ PLESSIS, Jean Jacques du. HARGOVAN, Anil. BAGARIC, Mirko. HARRIS, Jason. Principles of contemporary corporate governance. Australia, Cambrigde University Press, 2015. p.367.

${ }^{377}$ MATTOS, Eduardo da Silva. O que a crise do subprime ensinou ao Direito? Tese (Doutorado em Direito Comercial) - Faculdade de Direito, Universidade de São Paulo, São Paulo, 2014. p.85.

${ }^{378}$ PLESSIS, Jean Jacques du. HARGOVAN, Anil. BAGARIC, Mirko. HARRIS, Jason. Principles of contemporary corporate governance. Australia, Cambrigde University Press, 2015. p.368.

${ }^{379}$ MATTOS, Eduardo da Silva. op.cit. p.87.
} 
financeiro, "proibindo qualquer instituição financeira de fazer aquisições ou fusões que resultem em uma instituição com mais de dez por cento dos passivos do setor ${ }^{380}$, . Foram considerados bancos importantes aqueles que possuíssem $\$ 50$ bilhões de dólares ou mais em ativos; grandes os com $\$ 10$ bilhões ou mais e pequenos aqueles com menos de $\$ 10$ bilhões em ativos. A Seção 165 abordou a necessidade de supervisão e de padrões prudentes para instituições não bancárias com o objetivo de prevenir e mitigar riscos sistêmicos que prejudiquem a estabilidade financeira, como a definição de requisitos quantitativos de capital baseados no risco; requisitos de liquidez; análise de situações e a gestão de riscos e a especificação dos requisitos de segurança; relatórios de exposição a riscos e limites à concentração.

Trouxe a norma, em sua seção 202 que aquele que agir de forma imprudente na divulgação de informações sobre a instituição financeira será multado em até \$250 mil dólares e/ou condenado à pena de prisão por até 05 anos. Com o objetivo de evitar fraudes em um mecanismo amplamente utilizado com são os contratos de $\operatorname{swap}^{381}$ a seção 723 , será considerada uma ilegalidade que terceiras pessoas participem de contratos firmados entre dois participantes. Assim, a norma evita que investidores façam parte apenas de negócio lucrativos e fraudem o contrato em caso de desvalorização deste.

A figura do insider trading foi regulamentada e proibida pela seção 746, da DoddFrank. Segundo a norma é proibida a participação daquele funcionário de qualquer agência ou departamento do Governo Federal que tenha conhecimento de informações privilegiadas em contratos e operações em que tais informações possam ocasionar-lhe ganhos pessoais, bem como uma terceira pessoa utilizar-se destas informações.

Promulgada após a grave crise dos subprime a Lei Dodd-Frank trouxe consigo uma carga considerável de preocupação com a falta de regulamentação no sistema financeiro. $\mathrm{O}$ fato dos bancos e instituições financeiras não terem ideia da gravidade da crise até pouco tempo antes do seu auge evidenciou que novos padrões de supervisão e vigilância eram

\footnotetext{
${ }^{380}$ RIBEIRO, Ivan César. Regulação financeira, poder no mercado e crise financeira. Tese (Doutorado em Direito Comercial) - Faculdade de Direito, Universidade de São Paulo, São Paulo, 2012. p.294.

381،A palavra swap significa troca, e é uma estratégia financeira em que dois agentes concordam em trocar fluxos futuros de caixa de maneira preestabelecida. Este tipo de contrato surgiu da necessidade de proteção ao risco que muitas empresas possuíam em meados da década de 70 devido às suas atividades comerciais internacionais, muito afetadas pelas enormes variações das taxas de câmbio no período". Estes contratos são ajustados de acordo com o agente que dele participa. "A liquidação acontece, normalmente, na data de vencimento e, para que haja encerramento antecipado do contrato, é necessário um acordo entre as partes." LIMA, Iran Siqueira (coord.). LIMA, Gerlando Augusto Sampaio Franco de (coord.). PIMENTEL, Renê Coppe (coord.). Curso de Mercado Financeiro: tópicos especiais. São Paulo: Atlas, 2006. p.443.
} 
imperativos. Assim, a Dodd-Frank veio como uma reforma total do sistema financeiro, buscando regulamentar inclusive a criação de novos produtos financeiros, evitando que estes sejam utilizados para esconder fraudes e ativos podres. A crise de 2008 mostra a complexidade do mercado financeiro, em especial, sendo bastante desafiador para a regulação acompanhar sua evolução. Para isso, as agências de análise de risco precisam agora fundamentar suas avaliações com informes feitos por entidades independentes. A afirmação de que as instituições "too big to fail" não seriam mais resgatadas traz ainda algumas inseguranças sobre o enforcement da regulação, considerando que, ainda que o Lehman Brothers tenha sido escolhido como exemplo, há ainda a preocupação em relação ao comprometimento das grandes instituições financeiras e bancárias com os programas de prevenção e correta análise de riscos.

\subsection{Bribery Act}

O Bribery Act trata-se de uma norma britânica, colocada em prática em 2011, cujo objetivo envolve a prevenção de práticas relacionadas com a corrupção. O Ato criou quatro novos delitos: 1) a prática de suborno que vai caracterizar-se quando uma pessoa oferecer, prometer ou der vantagens, de cunho econômico ou outro, com a intenção de induzir uma pessoa a agir de forma imprópria ou recompensá-la por esta atitude (seção 1); 2) quando uma pessoa concordar em receber ou aceitar vantagens, que podem ser financeiras, como consequência por exercer sua função de forma indevida, quando se esperava que esta exercesse suas obrigações de forma imparcial ${ }^{382}$ (seção 2); 3) o suborno de de um funcionário público estrangeiro com o intuito de influenciar sua capacidade obtendo, assim, vantagens comerciais ${ }^{383}$ (seção 6); e 4) falhas de prevenção à corrupção nas organizações comerciais, quando a empresa subornar uma pessoa com a intenção de obter ou manter negócios ou vantagens com esta conduta (seção 7).

Conforma trazido anteriormente, a lógica da autorregulação regulada faz com que o Estado "privatize" parte das funções que possuía no âmbito da prevenção à criminalidade

\footnotetext{
${ }^{382} \mathrm{O}$ Bribery Act estabelece que serão consideradas funções ou atividades relevantes, de acordo com sua seção 3: qualquer função de natureza pública; relacionada com negócios; qualquer atividade executada no curso das atividades normais de uma determinada profissão; e qualquer atividade executada por ou em nome de uma entidade (corporativa ou não).

${ }^{383} \mathrm{~A}$ influência nas atividades desempenhadas pelo funcionário público envolve que este aja de forma omissiva no desempenho de suas funções ou utilize-se de sua posição para atingir um determinado resultado (seção 6.4). Será considerado um "funcionário público estrangeiro" aquele que detenha qualquer posição no âmbito legislativo, administrativo ou judicial (seção 6.5).
} 
dentro das empresas. Solicitando às empresas que fiscalizem suas próprias atividades, o Bribery Act criou um novo delito denominado "failure of comercial organisation to prevent bribery ${ }^{384}$ ". Esta conduta poderá ser aplicada contra empresas presentes no Reino Unido ou sobre aquelas que mantenham lá parte de suas operações (seção 7.5). Esta seção foi criticada por não estabelecer a previsão de, ao menos, uma acusação contra algum funcionário, optando o legislador por deixar a responsabilidade da empresa a mais ampla possível $^{385}$.

De acordo com a Lei, a organização poderá realizar sua defesa comprovando que possuía procedimentos adequados de prevenção a estas práticas (seção 7.2). Neste caso, o crime da falha na prevenção por parte da empresa terá como "fato provado" a ocorrência da prática de corrupção e como "fato presumido" a falha com seus deveres preventivos ${ }^{386}$.

O Bribery Act previu que orientações seriam publicadas com os procedimentos relevantes para os programas de prevenção à corrupção dentro das organizações (seção 9). O governo disponibilizou, em 2011, estes procedimentos, com o propósito de ajudar as organizações a entenderem melhor a legislação e com o problema da corrupção. $\mathrm{O}$ documento deixa claro que a prevenção aos riscos de práticas de corrupção envolve mais do que procedimentos onerosos, a criação de um sentimento comum de justo ${ }^{387}$. Em relação às criticas relacionadas aos custos de cumprir com as exigências previstas, afirma $o$ Secretário de Justiça que assina o documento, Kenneth Clarke, que não se deve escolher entre combater a corrupção ou privilegiar o crescimento econômico, uma vez que o objetivo é criar condições adequadas para que o mercado prospere.

Seis princípios são trazidos pelo Guia de aplicação do Bribery Act, com a ressalva de que o grau de exigência varia de acordo com as circunstâncias como, por exemplo, o tamanho da empresa e à sua exposição a riscos vinculados à corrupção. $O$ conteúdo disposto na seção 7 corrobora a política de prevenção iniciada já dentro da própria

\footnotetext{
${ }^{384}$ NIETO MARTÍN, Adán. La privatización de la lucha contra la corrupción. In: ARROYO ZAPATERO, Luis (dir.). NIETO MARTÍN, Adán (dir.). El derecho penal económico en la era compliance. Valência: Ed. Tirant lo Blanch, 2013. p.202.

${ }^{385}$ AZEVEDO, André Mauro Lacerda. Bribery Act 2010: um novo paradigma no enfrentamento da corrupção. Revista Brasileira de Ciências Criminais, São Paulo, v. 23, n. 113, mar./abr. 2015. p.418.

${ }^{386}$ AZEVEDO, André Mauro Lacerda. op.cit. p.425.

${ }^{387}$ UNITED KINGDOM MINISTRY OF JUSTICE. The Bribery Act 2010: Guidance about procedures which relevant commercial organisations can put into place to prevent persons associated with them from bribing. Março de 2011. p.02.
} 
empresa, pois a existência de procedimentos internos é importante para que seja possível investigar ou reportar incidentes de suborno em suas atividades.

A pessoa, que dispõe de uma determinada função, agirá de forma imprópria quando houver uma quebra na expectativa na performance que deveria ter sido realizada. $O$ Bribery Act estabelece, em sua seção 5, que esta noção de expectativa adequada será compreendida dentro dos padrões e valores esperados por uma pessoa razoável no Reino Unido, em relação àquela função determinada, e por decisões judiciais ou estatutos escritos. Este padrão de razoabilidade é aplicado, como trazido de exemplo nas Orientações, nas práticas corriqueiras do contexto empresarial. Conforme é explicado, o Bribery Act não busca criminalizar condutas que busquem melhorar a imagem de uma determinada empresa, apenas ressalta que em algumas situações, elas poderão ser vistas como irregulares.

O guia de orientações para melhor aplicação das normas previstas no Bribery Act trouxe seis princípios que podem auxiliar as empresas ${ }^{388}$. Integrado às recomendações da OCDE para incorporar boas práticas às atividades econômicas, estes princípios do Bribery Act não possuem caráter obrigatório para que as empresas os implementem, mas são oferecidos consideráveis benefícios para aquelas que o fizerem ${ }^{389}$. O primeiro princípio são os procedimentos proporcionais que devem ser implementados pelas empresas, em conformidade com os riscos trazidos pela complexidade, o tamanho e a natureza de suas atividades. Este princípio ressalta a importância das práticas de governança corporativa, transparência nas informações, due diligence, auditorias e controle e monitoração dos dispositivos aplicados.

O segundo princípio determina a importância da participação do alto escalão de funcionários de uma empresa, aqui compreendidos os diretores, Conselho de administração e mesmo os próprios donos da organização. O esforço destas figuras mostra-se necessário para a promoção de um efetivo comprometimento com as boas práticas, desenvolvendo maior transparência nas avaliações dos riscos e nas tomadas de decisão. A avaliação dos riscos engloba o terceiro princípio, demandando das empresas que verifiquem a exposição da empresa a riscos internos e externos, de forma periódica e documentada.

\footnotetext{
${ }^{388}$ UNITED KINGDOM MINISTRY OF JUSTICE. op.cit. p. 21 e ss.

${ }^{389}$ ROSE, Cecily. International anti-corruption norms: their creation and influence on domestic legal systems. Reino Unido: Oxford University Press, 2015. p.80.
} 
Os procedimentos de due diligence são trazidos pelo quarto princípio do Bribery Act. É importante que as empresas exerçam diligências adequadas não só internamente, mas também com seus parceiros comerciais e empresas terceirizadas, por exemplo. A importância da comunicação e a necessidade de um adequado treinamento para os funcionários determinam o quinto princípio. $\mathrm{O}$ treinamento possibilita o conhecimento e o desenvolvimento de habilidades que são imprescindíveis para a prevenção da corrupção. A existência de códigos de conduta e também de canais de comunicação evidenciam o comprometimento da empresa com as boas práticas exigidas pela Lei. Por último, o monitoramento e a revisão periódica dos programas implementados representam o sexto princípio.

A seção 12 do Bribery Act representa uma ampliação da jurisdição penal ${ }^{390}$, ao considerar que a norma será aplicada a todos os atos ou omissões cujos autores mantenham alguma conexão com o Reino Unido (seção 12.2). Com esta disposição, o Reino Unido afastou-se de outras normas internacionais que entendem a cooperação entre países uma importante ferramenta no combate e prevenção à corrupção ${ }^{391}$.

O estudo do Bribery Act levantou algumas importantes considerações em relação às politicas de prevenção à criminalidade econômica. Vista como uma norma rígida, o Act elevou a necessidade das práticas de governança corporativa e avaliação de riscos ao criar o crime de falha empresarial na prevenção à corrupção, que exige das empresas maior controle sobre suas atividades. A preocupação resta, mais uma vez, em saber como as avaliações serão feitas, especialmente em uma lei tão rigorosa que não delimita multas que podem ser aplicadas.

\subsection{Normativa aplicável no Brasil}

\subsubsection{Lei de Lavagem de Dinheiro (Lei 12.683/2012)}

Com o objetivo de evitar a entrada de capital ilícito na economia formal, o governo dos Estados Unidos, na década de 80, notou a necessidade da adoção de políticas eficazes contra a lavagem de dinheiro e estabeleceu alguns pontos principais, como a instabilidade

\footnotetext{
${ }^{390}$ AZEVEDO, André Mauro Lacerda. Bribery Act 2010: um novo paradigma no enfrentamento da corrupção. Revista Brasileira de Ciências Criminais, São Paulo, v. 23, n. 113, mar./abr. 2015. p.431.

${ }^{391}$ AZEVEDO, André Mauro Lacerda. Bribery Act 2010: um novo paradigma no enfrentamento da corrupção. Revista Brasileira de Ciências Criminais, São Paulo, v. 23, n. 113, mar./abr. 2015. p.432-433.
} 
financeira causada pelo deslocamento de recursos de origem desconhecida; o risco à integridade e à reputação do sistema; a menor arrecadação de impostos e as repercussões socioeconômicas causadas pelo refinanciamento de novas atividades criminosas ${ }^{392}$.

Em 1986, foi criado o Money Laundering Control Act, com penas de até 20 anos para o crime de lavagem de dinheiro, cujo objetivo foi inspirado na necessidade apresentada pelo sistema financeiro de diminuir a interferência do poder econômico das grandes organizações criminosas ${ }^{393}$. No ano de 1988, a Convenção de Viena impôs aos Estados aderentes que adotassem providências penais contra as práticas de lavagem de dinheiro $^{394}$.

De acordo com Isidoro Blanco Cordero, a política criminal adotada é caracterizada por uma forte regulação para prevenir, detectar e sancionar as práticas de lavagem de dinheiro. Em um contexto de desregulamentação dos mercados financeiros, houve uma série de normas administrativas criadas com o objetivo de impedir o acesso deste dinheiro proveniente de delitos ao sistema financeiro ${ }^{395}$. Desta forma, ficaram proibidas práticas que comprometessem a livre circulação de bens no mercado e que pudessem afetar a concorrência e seus ideais de transparência ${ }^{396}$.

Com a pressão mundial, o Brasil aprovou a Lei n.9613, no ano de 1998. Previa, em seu art. $1^{\circ}$, um rol taxativo de delitos ao qual estaria vinculada a prática de lavagem de dinheiro. Dentre as infrações estavam o tráfico ilícito de substâncias entorpecentes; terrorismo e seu financiamento; contrabando ou tráfico de armas, munições ou material destino à sua produção; extorsão mediante sequestro; infrações contra a Administração Pública e contra o sistema financeiro nacional; praticadas por organização criminosa ou particular contra a administração pública estrangeira. Entretanto, a punição de tantos

\footnotetext{
${ }^{392}$ CARDOSO, Débora Motta. Greco Filho, Vicente. A extensão do compliance no direito penal análise crítica na perspectiva da lei de lavagem de dinheiro. São Paulo: Tese-USP, 2013. p.18-20.

${ }^{393}$ CARDOSO, Débora Motta. op.cit. p. 21 .

${ }^{394}$ CARDOSO, Débora Motta. op.cit. p.22.

${ }^{395}$ BLANCO CORDERO, Isidoro. Eficacia del sistema de prevención del blanqueo de capitales. Estudio del cumplimiento normativo (compliance) desde una perspectiva criminológica. Eguzkilore: Cuaderno del Instituto Vasco de Criminología, San Sebastian, n. 23, p.117-138, 2009. p.117.

${ }^{396}$ SAAD-DINIZ, Eduardo. Os danos sociais da lavagem de dinheiro. In: SILVEIRA, Renato de Mello Jorge (coord.). Crônicas franciscanas no Mensalão. São Paulo: Quartier Latin, 2014. p.85.
} 
“delitos instrumentais" não se mostrou efetiva para diminuir a incidência dos outros com os quais se relacionam ${ }^{397}$.

A Lei exige que as pessoas sujeitas aos mecanismos de controle (art. $9^{\circ}$ ), como bolsas de valores, corretoras de seguros e sociedade que efetuem distribuição de dinheiro ou quaisquer bens móveis, imóveis, mercadorias e serviços, identifiquem seus clientes (art.10, inciso I) e mantenham um registro de toda transação financeira realizada (art.10, inciso II). Importante ressaltar que a suspeita da incompatibilidade entre a situação econômica do cliente e as operações realizadas gera à instituição financeira o dever de comunicar a transação às autoridades competentes.

No Brasil, a Lei n.12.683/2012, que modificou a Lei n.9613/1998, teve por objetivo tornar mais eficiente a persecução penal aos crimes de lavagem de dinheiro. Não há mais a restrição taxativa sobre os crimes antecedentes, tendo a modificação expandido o âmbito de tipificação do crime de lavagem ${ }^{398}$. Serão consideradas práticas de lavagem de dinheiro ações que busquem "ocultar ou dissimular a natureza, origem, localização, disposição, movimentação ou propriedade de bens, direitos ou valores provenientes, direta ou indiretamente, de infração penal" (art. $2^{\circ}$ ). Esta conduta mostra-se altamente profissional ao fazer uso da alta mutabilidade das práticas financeiras, evidenciando a dificuldade causada pela globalização ao controle estatal ${ }^{399}$.

Incorrerá na mesma pena $\left(\S \S 1^{\circ}\right.$ e $2^{\circ}$, do art. $\left.2^{\circ}\right)$ quem "para ocultar ou dissimular a utilização de bens, direitos ou valores provenientes de infração penal", os converter em ativos ilícitos; adquirir, receber, trocar, negociar, dar ou receber em garantia, guardar, ter em depósito, movimentar ou transferir; importar ou exportar bens com valores não correspondentes aos verdadeiros; utilizar, na atividade econômica ou financeira, bens, direitos ou valores provenientes de infração penal e quem participar de "grupo, associação

\footnotetext{
${ }^{397}$ SALVADOR NETTO, Alamiro Velludo. Lavagem de dinheiro e seu protagonismo no direito penal. In: SILVEIRA, Renato de Mello Jorge (coord.). Crônicas franciscanas no Mensalão. São Paulo: Quartier Latin, 2014. P.88.

${ }^{398}$ DUARTE, Maria Carolina de Almeida. A globalização e os crimes de "lavagem de dinheiro": a utilização do sistema financeiro como porto seguro. Ciências Penais: Revista da Associação Brasileira de Professores de Ciências Penais, São Paulo, v. 1, n. 0, jan./jun. 2004. p.215 e ss.

${ }^{399}$ CARDOSO, Débora Motta. Greco Filho, Vicente. A extensão do compliance no direito penal análise crítica na perspectiva da lei de lavagem de dinheiro. São Paulo: Tese-USP, 2013. p.47.
} 
ou escritório tendo conhecimento de que sua atividade principal ou secundária é dirigida à prática de crimes previstos" em lei ${ }^{400}$.

O Capítulo VI ("Da identificação dos clientes e manutenção de registros”), também sofreu alterações. As pessoas físicas e jurídicas (art. $9^{\circ}$ ), sujeitas ao mecanismo de controle da Lei de Lavagem, deverão “adotar políticas, procedimentos e controles internos, compatíveis com seu porte e volume de operações"; "cadastrar-se e manter seu cadastro atualizado no órgão regulador ou fiscalizar e, na falta deste, no Conselho de Controle de Atividades Financeiras (COAF)", a quem as pessoas deverão atender às requisições, "na periodicidade, forma e condições" estabelecidas. As políticas de know your client representam "o dever institucional de identificar e registrar as transações de seus clientes $^{401,}$.

Na Europa, é possível, caso o comunicado faça com que o cliente suspeite do monitoramento, que a instituição financeira permita a transação e, somente, após a conclusão, comunique a ilegalidade. Entretanto, no Brasil, a comunicação deverá ser realizada previamente à operação, para que assim não haja responsabilização penal ${ }^{402}$.

As práticas de lavagem de dinheiro são caracterizadas por operações complexas cuja finalidade é mascarar a origem ilícita do dinheiro a ser reinserido na economia formal. Para este fim, são utilizadas diversas técnicas de ocultação da origem que se somam à falta de estrutura, à dificuldade de monitoramento de todas as transições financeiras e com as

\footnotetext{
${ }^{400}$ Sobre o assunto, importante mencionar a Ação Direta de Inconstitucionalidade n. 4841, proposta pela Confederação Nacional das Profissões Liberais dirigida contra o art. $2^{\circ}$ da Lei n.12683/12, na parte que alterou os art. $9^{\circ}$, parágrafo único, XIV; art. 10 e art.11 da Lei n.9613/98 que incluíram os profissionais liberais entre as pessoas sujeitas aos mecanismos de controle e a consequente imposição dos deveres de identificação dos clientes, de manutenção dos registros e de comunicação das operações financeiras. Sustentam que as profissões liberais seriam regidas por deveres de sigilo específicos (advogado, contador, corretores de imóveis, economistas, arquitetos, médico, entre outros). Portanto, ao violar com o sigilo profissional próprio das profissões liberais, a Lei de Lavagem de Dinheiro estaria em desacordo com os princípios constitucionais da proporcionalidade, proibição de excesso e razoabilidade. O Ministério Público Federal entendeu que esta obrigação seria uma medida presente nas 40 Recomendações do GAFI (Groupe d`Action Financière, órgão internacional criado pelo G7 para propor politicas necessárias à prevenção do crime de lavagem) e que o sigilo profissional não poderia ser considerado absoluto, uma vez que convive com outros interesses constitucionalmente relevante, bem como encontra cláusulas de exceção nos códigos de conduta das mencionadas profissões liberais. No que tange à exigência da quebra de sigilo dos advogados, defendeu o CFOAB que a Lei de Lavagem não poderia revogar o Estatuto da Advocacia, além de não ter trazido expressamente que os advogados estariam vinculados ao dever de comunicação. A questão ainda demanda um fundamentado debate para que seja dada aos profissionais liberais, incluídos aqui os advogados, segurança jurídica para o desenvolvimento de suas funções.

${ }^{401}$ SILVEIRA, Renato de Mello Jorge; SAAD-DINIZ, Eduardo. Compliance, Direito Penal e Lei Anticorrupção. São Paulo: Saraiva, 2015. p.267.

${ }^{402}$ CARDOSO, Débora Motta. op.cit. p.105-112.
} 
rígidas regras de sigilo bancário ${ }^{403}$. Esta complexidade é evidenciada na dificuldade encontrada pelos governos nacionais e organizações internacionais em mensurar a eficácia das normas e políticas penais ${ }^{404}$, uma vez que não há dados suficientes e precisos sobre a entrada e saída de dinheiro nos bancos e instituições financeiras.

Os deveres de compliance foram ampliados com a lei 12.683/2012 $2^{405}$ que passou a exigir que as empresas adotassem "políticas, procedimentos e controles internos, compatíveis com seu porte e volume de operações" (art.10, III). Tais deveres estariam relacionados com a identificação de movimentações financeiras que poderiam indicar a ocorrência do crime de lavagem de capitais ${ }^{406}$. Em termos de prevenção, a Lei estipulou obrigações e deveres de informação de atividades suspeitas e as instituições financeiras passaram a ter um dever de cooperação com o sistema criminal $^{407}$.

Se antes as práticas de compliance eram vistas como uma forma de melhorar a relação da empresa com seus stakeholders, com a Lei de Lavagem de Dinheiro elas passaram a desempenhar um papel jurídico-penal importante, com novas formas de responsabilização e controle estatal ${ }^{408}$. As atividades financeiras passaram a ter um importante papel na política-criminal de combate aos crimes de lavagem e a implementação de políticas de compliance encontrou um ambiente favorável com a convergência dos interesses estatais e das instituições financeiras ${ }^{409}$.

A Lei de Lavagem de Dinheiro deu às práticas de compliance um dever legal de colaboração, das pessoas jurídicas e físicas, com as autoridades competentes nos procedimentos de identificação da prática do crime e no desenvolvimento de mecanismos de prevenção ${ }^{410}$. As instituições passaram a implementar sistemas internos, como por exemplo softwares capazes de mapear o destino do dinheiro (no caso dos paraísos

\footnotetext{
${ }^{403}$ CARDOSO, Débora Motta. op.cit. p.92.

${ }^{404}$ BLANCO CORDERO, Isidoro. Eficacia del sistema de prevención del blanqueo de capitales. Estudio del cumplimiento normativo (compliance) desde una perspectiva criminológica. Eguzkilore: Cuaderno del Instituto Vasco de Criminología, San Sebastian, n. 23, p.117-138, 2009. p.126.

${ }^{405}$ SAAVEDRA, Giovani Agostini. Compliance na nova lei de lavagem de dinheiro. Revista Síntese de direito penal e processual penal, Porto Alegre, v. 13, n. 75, ago./set. 2012.p. 27.

${ }^{406}$ SAAVEDRA, Giovani Agostini. op.cit.p. 29.

${ }^{407}$ SILVEIRA, Renato de Mello Jorge; SAAD-DINIZ, Eduardo. Criminal compliance: os limites da cooperação normativa quanto à lavagem de dinheiro. Revista peruana de ciencias penales, Lima, n. 25, 2013. p.593.

${ }^{408}$ SAAVEDRA, Giovani Agostini. Compliance e prevenção na Lei de lavagem de dinheiro: sobre os reflexos da Lei n. 12.683/2012 no mercado de seguros. Revista de Estudos Criminais, Porto Alegre, v. 12, n. 54, jul./set. 2014. p.166-169.

${ }^{409}$ CARDOSO, Débora Motta. op.cit. p. 195.

${ }^{410}$ CARDOSO, Débora Motta. op.cit. p.50.
} 
fiscais $)^{411}$. A característica de atuação posterior ao fato do direito penal foi substituída por sistemas que precisam acompanhar todo o ordenamento legal, nacional e internacional, como forma de garantir que as empresas e instituições bancárias realizem suas atividades dentro dos limites legais ${ }^{412}$.

Diante da complexidade dos atos de lavagem, foi criado, no âmbito do Ministério da Fazenda, o COAF (Conselho de Controle de Atividades Financeiras), com "a finalidade de disciplinar, aplicar penas administrativas, receber, examinar e identificar as ocorrências suspeitas de atividades ilícitas previstas nesta lei” (art. 14). O COAF tem por função comunicar as autoridades competentes para a instauração dos procedimentos necessários, "quando concluir pela existência de crimes previstos nesta lei" (art.15). Este sistema de inteligência deve ser capaz de "monitorar informações, sistematizar dados e gerar relatórios precisos sobre práticas de mascaramento de capitais, manejado por equipes qualificadas para gestão do conhecimento e para o desenvolvimento de novas estratégias de localização e averiguação de atos de lavagem ${ }^{413}$ ".

O Relatório do $\mathrm{COAF}^{414}$, sobre suas atividades em 2015, mostra que foram produzidos 4.304 RIF (Relatórios de Inteligência Financeira), relacionados a aproximadamente 140 mil pessoas físicas e jurídicas. Sua base de dados total conta com mais de 11 milhões de comunicações de operações financeiras e, destas, 1,3 milhão foram recebidas no ano de 2015. Com estas informações, foi possível realizar o bloqueio de mais de $\mathrm{R} \$ 50$ milhões no Brasil e no exterior, relacionados a investigações sobre lavagem de dinheiro e crimes relacionados. A partir do momento em que é detectado um sinal de alerta, é calculado o risco inerente à comunicação recebida e gerada uma pasta virtual para o aprofundamento da análise. Os resultados são registrados em Relatórios de Inteligência Financeira, porém quando encontrados indícios de crimes de lavagem de dinheiro ou outro ilícito qualquer, os Relatórios serão encaminhados às autoridades competentes.

\footnotetext{
${ }^{411}$ BLANCO CORDERO, Isidoro. Eficacia del sistema de prevención del blanqueo de capitales. Estudio del cumplimiento normativo (compliance) desde una perspectiva criminológica. Eguzkilore: Cuaderno del Instituto Vasco de Criminología, San Sebastian, n. 23, p.117-138, 2009. p.124.

${ }^{412}$ SAAVEDRA, Giovani Agostini. op.cit. p.172.

${ }^{413}$ BOTTINI, Pierpaolo Cruz. Política de Combate à Lavagem de dinheiro. In: BADARÓ, Gustavo Henrique; BOTTINI, Pierpaolo Cruz. Lavagem de dinheiro: aspectos penais e processuais penais: comentários à Lei 9.613/1998, com as alterações da Lei 12.683/2012. 2.ed. rev.atual e ampl. São Paulo: Revista dos Tribunais, 2013. p.42.

${ }^{414}$ CONSELHO DE CONTROLE DE ATIVIDADES FINANCEIRAS. Relatório de Atividades 2015. Publicado em 07 de abril de 2016. Disponível em: <http://www.coaf.fazenda.gov.br/noticias/coaf-publica-orelatorio-de-atividades-2015>. Acesso em 30 de maio de 2016.
} 
A Lei n. 12.683/12 apresentou um recrudescimento no tratamento dos delitos econômicos no Brasil, seguindo uma tendência internacional de combate ao fluxo financeiro como fonte de perigo ${ }^{415}$. Busca-se aumentar os riscos de sanção ao infrator com as políticas de rastreio ("follow the money"), que "consistem em seguir o dinheiro de origem delitiva, evitando seu aproveitamento e fomentando a criminalização" da lavagem $^{416}$. O Estado, reconhecendo sua incapacidade para prevenir ou investigar os delitos sem a colaboração das instituições privadas, com as técnicas de cooperação tem por objetivo isolar o agente criminoso e dificultar o seu acesso ao sistema financeiro ${ }^{417}$.

Críticas entendem que o risco neste contexto é que a Lei utilize o agente financeiro como um instrumento de repressão e puna excessivamente alguém que deixe de denunciar às autoridades uma movimentação de capital $^{418}$. Este é o entendimento também de Helena Regina Lobo da Costa, ao afirmar ser incoerente o igual tratamento dispensado aquele que lava valores oriundos do tráfico de drogas e outro que faça o mesmo com valores provenientes de um furto $^{419}$, ferindo o princípio da proporcionalidade.

A Lei de Lavagem de Dinheiro evidencia a necessidade de prevenção realizada junto às instituições financeiras. $\mathrm{O}$ direito penal econômico passa a ser visto como um reforço para que o mercado funcione de forma equilibrada, atuando na posição de "porrete" em caso de necessidade. Por ser uma atividade clandestina e de difícil rastreio, a lavagem de dinheiro demanda deveres de colaboração aos bancos e instituições e a implementação de sistemas internos de controle e vigilância que se não observados resultarão em responsabilizações penais e administrativas. A complexidade das atividades e os meios pelos quais os delitos são praticados evidenciam a importância da mudança da mentalidade da repressão para as práticas de prevenção.

\footnotetext{
${ }^{415}$ RODRIGUEZ, Victor Gabriel. Lendas e equívocos do crime de lavagem de dinheiro. In: SILVEIRA, Renato de Mello Jorge (coord.). Crônicas franciscanas no Mensalão. São Paulo: Quartier Latin, 2014. p.77.

${ }^{416}$ SILVEIRA, Renato de Mello Jorge; SAAD-DINIZ, Eduardo. Compliance, Direito Penal e Lei Anticorrupção. São Paulo: Saraiva, 2015. p.254.

${ }^{417}$ BOTTINI, Pierpaolo Cruz. Política de Combate à Lavagem de dinheiro. In: BADARÓ, Gustavo Henrique; BOTTINI, Pierpaolo Cruz. Lavagem de dinheiro: aspectos penais e processuais penais: comentários à Lei 9.613/1998, com as alterações da Lei 12.683/2012. 2.ed. rev.atual e ampl. São Paulo: Revista dos Tribunais, 2013. p.35.

${ }^{418}$ RODRIGUEZ, Victor Gabriel. op.cit. p.78.

${ }^{419}$ COSTA, Helena Regina Lobo. Exageros e incoerências da lei $n^{\circ} .12 .683 / 12$. In: SILVEIRA, Renato de Mello Jorge (coord.). Crônicas franciscanas no Mensalão. São Paulo: Quartier Latin, 2014. p.130.
} 


\subsubsection{Lei Anticorrupção (Lei 12.846/2013)}

A pressão internacional pela adoção de medidas contra corrupção tem na lei n.12.846/2013 um claro resultado. A Convenção Internacional sobre o Combate da Corrupção de Funcionários Públicos Estrangeiros (Decreto nº 3678, de 30 de novembro de 2000) considerou, em seu preâmbulo, a corrupção como "um fenômeno difundido nas Transações Comerciais Internacionais, incluindo o comércio e o investimento que desperta sérias preocupações morais e políticas, abala a boa governança e o desenvolvimento econômico, e distorce as condições internacionais de competitividade”. Trouxe ainda a importância da ação conjunta de companhias, organizações empresariais, organizações não governamentais e Governos no combate à corrupção, em âmbito nacional e internacional.

Em seu artigo $2^{\circ}$, a Convenção determinou que "cada parte deverá tomar todas as medidas necessárias ao estabelecimento das responsabilidades de pessoas jurídicas pela corrupção de funcionário público estrangeiro", cabendo às partes signatárias, de acordo com o artigo $8^{\circ}$, "tomar as medidas necessárias, no âmbito de suas leis e regulamentos sobre manutenção de livros e registros contábeis, divulgação de declarações financeiras, e sistemas de contabilidade e auditoria, para proibir o estabelecimento de caixa 'dois', a realização de operações de caixa 'dois' ou operações inadequadamente explicitadas, o registro de despesas inexistentes, o lançamento de obrigações com explicitação inadequada de seu objeto, bem como o uso de documentos falsos por companhias sujeitas àquelas leis e regulamentos com propósito de corromper funcionários públicos estrangeiros ou ocultar tal corrupção". Como consequência, caberá às partes prover penas civis, administrativas e criminais que sejam efetiva, proporcionais e dissuasivas.

Com grande influência de teorias da seara econômica ${ }^{420}$, a Lei n.12.846/2013 dispõe sobre a responsabilização objetiva administrativa e civil de pessoas jurídicas pela prática de atos contra a administração pública, nacional ou estrangeira (art. $1^{\circ}$, caput). As pessoas jurídicas serão responsabilizadas objetivamente, nos âmbitos administrativo e civil pelos atos lesivos previstos nesta lei praticados em seu interesse ou benefício, exclusivo ou não (art. $2^{\circ}$ ). Conforme afirma Renato Silveira, com a Lei Anticorrupção foi dado foco à

\footnotetext{
${ }^{420}$ SILVEIRA, Renato de Mello Jorge; SAAD-DINIZ, Eduardo. Compliance, Direito Penal e Lei Anticorrupção. São Paulo: Saraiva, 2015. p.306.
} 
problemática da responsabilidade individual $^{421}$ : os dirigentes ou administradores somente serão responsabilizados pelos atos ilícitos na medida de sua culpabilidade ( $\operatorname{art} .3^{\circ}, \S 2^{\circ}$ ).

São considerados atos lesivos à administração, dentre outros: “prometer, oferecer ou dar, direta ou indiretamente, vantagem indefinida a agente público, ou a terceira pessoa a ele relacionada" (art.5 $5^{\circ}$ inciso I); "frustrar ou fraudar, mediante ajuste, combinação ou qualquer outro expediente, o caráter competitivo de procedimento licitatório público" (art.5\%, inciso III); "impedir, perturbar ou fraudar a realização de qualquer ato de procedimento licitatório público" (art.5, $\mathrm{IV}$, "b”); “fraudar licitação pública ou contrato dela decorrente" (art. 5', IV, “d”); "manipular ou fraudar o equilíbrio econômicofinanceiro dos contratos celebrados com a administração pública” (art.5º IV, “g”).

$\mathrm{Na}$ esfera administrativa, às pessoas jurídicas consideradas responsáveis pelos atos lesivos previstos serão aplicadas: multa, no valor de $0,1 \%$ a $20 \%$ do faturamento bruto do último exercício anterior ao da instauração do processo administrativo (art. $6^{\circ}$, I) e a publicação extraordinária da decisão condenatória (art.6º, II). Quanto a este artigo, causa dúvidas e preocupações a discricionariedade punitiva disponível à administração, uma vez que não constam na lei um rito administrativo a ser observado e um órgão especializado responsável pela condução do processo, especialmente com a existência de regulações estaduais e municipais que podem, ainda mais, trazer inseguranças aos processos ${ }^{422}$.

Na aplicação das sanções $\left(\operatorname{art.} 7^{\circ}\right)$ serão consideradas, por exemplo, a gravidade da infração (inciso I); a vantagem auferida ou pretendida pelo infrator (inciso II); a consumação ou não da infração (inciso III); o grau de lesão ou perigo de lesão (inciso IV); a situação econômica do infrator (inciso VI); e, mais importante para a presente pesquisa, a existência de mecanismos e procedimentos internos de integridade, auditoria e incentivo à denúncia de irregularidades e a aplicação efetiva de códigos de ética e de conduta no âmbito da pessoa jurídica (inciso VIII). Desta forma, este artigo estabeleceu alguns critérios, genéricos $^{423}$, para o dimensionamento das sanções a serem aplicadas,

\footnotetext{
${ }^{421}$ SILVEIRA, Renato de Mello Jorge; SAAD-DINIZ, Eduardo. Compliance, Direito Penal e Lei Anticorrupção. São Paulo: Saraiva, 2015.p. 183.

${ }^{422}$ SOUZA, Luciano Anderson de. Lei Anticorrupção: avanços e desafios. Boletim IBCCRIM, São Paulo, v. 22, n. 256, mar. 2014. p.05.

${ }^{423}$ SOUZA, Luciano Anderson de. op.cit. p.05.
} 
influenciadas estas pela adoção de práticas de autorregulação, ponderando os comportamentos pós-delitivos na atenuação da responsabilização da pessoa jurídica ${ }^{424}$.

Este $\operatorname{art} .7^{\circ}$ recebeu críticas ao igualar no mesmo grupo de responsabilidade objetiva empresas que, de fato, implementaram um programa de compliance efetivo, mas que apresentou algumas falhas e aquelas que se encontravam descomprometidas com as boas práticas $^{425}$, o que poderia ocasionar uma baixa adesão aos programas de cumprimento, quando ponderados seus custos e benefícios. Da mesma forma, falta à regulamentação uma definição específica de quais mecanismos e procedimentos serão considerados no momento da valoração das sanções. Esta falta de previsão é criticada por Renato Silveira principalmente pela condução do processo ser realizada em âmbito administrativo, sem contar com as garantias e padrões mínimos do Judiciário, diferentemente do procedimento trazido pela Lei de Lavagem de Dinheiro, que possui a sanção administrativa julgada em sede judicial, respeitando o contraditório e a ampla defesa ${ }^{426}$.

Estabelece a Lei uma estrutura de estímulos que passa a considerar mecanismos de compliance, programas de integridade e auditorias como necessárias à implementação pelas empresas, considerando o aspecto organizacional e a ética com a qual desenvolveu suas atividades ${ }^{427}$. Seu art.16, que versa sobre os acordos de leniência, trouxe "uma nova modalidade extintiva de responsabilidade - agora de caráter administrativo ${ }^{428,}$, diante da colaboração das pessoas jurídicas responsáveis pela prática dos atos e pelos fatos investigados e previstos pela Lei com as investigações e com o processo administrativo. A Medida Provisória $\mathrm{n}^{\circ} 703$, de 2015, trouxe nova redação ao art.17, estabelecendo que "a administração pública poderá também celebrar acordo de leniência com a pessoa jurídica responsável por atos e fatos investigados previstos em normas de licitações e contratos administrativos com vistas à isenção ou à atenuação das sanções restritivas ou impeditivas ao direito de licitar e contratar". Ressalta Renato Silveira que estas previsões mostram-se de forma incompleta e, diante do caráter penal da normativa, toda situação de

\footnotetext{
${ }^{424}$ BARBOSA, Julianna Nunes Targino. A culpabilidade na responsabilidade penal da pessoa jurídica. Faculdade de Direito, Universidade de São Paulo, São Paulo, 2014. p.56.

${ }^{425}$ SARCEDO, Leandro. Compliance e Responsabilidade Penal da Pessoa Jurídica: Construção de um novo modelo de imputação, baseado na culpabilidade corporativa. Faculdade de Direito, Universidade de São Paulo, São Paulo, 2014.p.168.

${ }^{426}$ SILVEIRA, Renato de Mello Jorge; SAAD-DINIZ, Eduardo. Compliance, Direito Penal e Lei Anticorrupção. São Paulo: Saraiva, 2015. p.196.

${ }^{427}$ BARBOSA, Julianna Nunes Targino. op.cit. p.181.

${ }^{428}$ SILVEIRA, Renato de Mello Jorge; SAAD-DINIZ, Eduardo. op.cit. p.193.
} 
abrandamento ou isenção de responsabilidade deveria estar prevista de forma clara e precisa $^{429}$.

A significativa carga penal mostra-se presente, por exemplo, no combate prévio às práticas de corrupção; nas sanções administrativas que podem resultar, inclusive, no fechamento da empresa; no cerceamento de defesa por trazer a responsabilidade objetiva para a prática empresarial ${ }^{430}$. Uma vez que estas medidas são apresentadas no âmbito administrativo, não dispõem as empresas da racionalidade e das garantias do processo penal $^{431}$.

Representando uma nova realidade em que as empresas passam a desempenhar o papel de controle e prevenção do Estado, a Lei Anticorrupção focou nas empresas que lucram e favorecem-se com as práticas corruptivas ${ }^{432}$. A empresa será responsabilizada se beneficiada, direta ou indiretamente, pelo comportamento desviado de seus funcionários e das empresas com as quais mantenham contratos ${ }^{433}$. Defende Pierpaolo Bottini e Igor Tamasauskas que, diante da efetiva presença de um programa de integridade, suficiente seria a empresa reparar os danos e ter os benefícios e vantagens recebidas pela conduta indevida sustados, pois qualquer punição com os objetivos de prevenção ou retribuição não teria justificativa, pela ausência de culpabilidade ${ }^{434}$.

Diante do atual estágio de globalização mundial, afirma Adán Nieto Martín que a capacidade reguladora e sancionadora dos Estados foi enfraquecida e as práticas de compliance mostraram-se um instrumento de governança global ${ }^{435}$ e mais efetiva que convênios internacionais e normas estatais, seria a pressão privada exercida por grandes

\footnotetext{
${ }^{429}$ SILVEIRA, Renato de Mello Jorge; SAAD-DINIZ, Eduardo. Compliance, Direito Penal e Lei Anticorrupção. São Paulo: Saraiva, 2015. p.194.

${ }^{430}$ SCAFF, Fernando Facury; SILVEIRA, Renato de Mello Jorge. Lei anticorrupção é substancialmente de caráter penal. Consultor Jurídico (São Paulo. Online), v. 1, p. 1, 2014.

${ }^{431}$ SILVEIRA, Renato de Mello Jorge; SAAD-DINIZ, Eduardo. op.cit. p.317.

${ }^{432}$ BOTTINI, Pierpaolo Cruz; TAMASAUSKAS, Igor. A controversa responsabilidade objetiva na Lei 12.846/13. Revista do Advogado, São Paulo, v. 34, n. 125, dez. 2014. p.126.

${ }^{433}$ BOTTINI, Pierpaolo Cruz; TAMASAUSKAS, Igor. op.cit. p. 127.

${ }^{434}$ BOTTINI, Pierpaolo Cruz; TAMASAUSKAS, Igor. op.cit. p.129.

${ }^{435}$ NIETO MARTÍN, Adán. Problemas fundamentales del cumplimiento normative en el derecho penal. In: KUHLEN, Lothar (ed.). MONTIEL, Juan Pablo (ed.). ORTIZ DE URBINA GIMENO, Iñigo (ed.). Compliance y teoria del derecho penal. Madrid: Marcial Pons, 2013. p.23.
} 
empresas que exijam a todos aqueles que queiram realizar contratos e serviços com elas que possuam sólidos programas anticorrupção ${ }^{436}$.

A exigência de "know your client" prevista na Lei de Lavagem de Dinheiro expande-se para a necessidade que a empresa exija de terceiros os mesmos critérios de ética e compliance aplicados em suas próprias atividades. O Estado, ciente de suas limitações, passa a exigir padrões de controle privatizados como forma de tentar controlar o grave problema da corrupção, demonstrando um excesso de rigor ao prever punições mesmo para empresas que tenham políticas de integridade atualizadas e implementadas.

\subsubsection{Decreto n. 60.106, de 29 de janeiro de 2014}

O decreto n. 60.106/14 buscou disciplinar a aplicação, no âmbito da Administração Pública estadual, dos dispositivos da Lei federal n. 12.846/13. Buscando regulamentar a Lei federal de forma rápida, o decreto manteve os problemas relacionados à ausência de parâmetros claros de aplicação das sanções estabelecidas pelo art. $7^{\circ}$ da Lei ${ }^{437}$.

Estabeleceu o art. $8^{\circ}$, da Lei federal que "a instauração e o julgamento de processo administrativo para apuração da responsabilidade de pessoa jurídica cabem à autoridade máxima de cada órgão ou entidade dos Poderes Executivo, Legislativo e Judiciário, que agirá de ofício ou mediante provocação, observados o contraditório e a ampla defesa". O decreto estadual trouxe em seu art. $2^{\circ}$ que a instauração e o julgamento do processo administrativo caberão, no âmbito da Administração direta, aos secretários de Estado e ao Procurador Geral do Estado, em suas respectivas esferas, ou ao Presidente da Corregedoria Geral da Administração; e no âmbito da Administração indireta e fundacional, ao dirigente superior de cada entidade. Entretanto, conforme afirmam Luciano Anderson de Souza ${ }^{438}$ e Vicente Greco Filho, junto com João Daniel Rassi ${ }^{439}$, este artigo seria inconstitucional ao atribuir a apuração e o julgamento de um ilícito administrativo a uma entidade da Administração indireta, uma vez que apenas entidades de direito público podem aplicar

\footnotetext{
${ }^{436}$ NIETO MARTÍN, Adán. Regulatory Capitalism y cumplimiento normativo. In: ARROYO ZAPATERO, Luis; NIETO MARTÍN, Adán (coord.). El derecho penal en la era compliance. Valencia: Tirant lo Blanch, 2013. p.15.

${ }^{437}$ SOUZA, Luciano Anderson de. Lei Anticorrupção: balanço de um semestre de muitos desacertos. Boletim IBCCRIM, São Paulo, v. 22, n. 260, jul. 2014. p.11.

${ }^{438}$ SOUZA, Luciano Anderson de. op.cit. p.11.

${ }^{439}$ GRECO FILHO, Vicente; RASSI, João Daniel. Decreto Estadual Anticorrupção contém inconstitucionalidade. Estadāo, São Paulo, 19 de fevereiro de 2014.
} 
medidas punitivas a particulares. Conforme previsto pelo art. 173, da Constituição Federal, as sociedades de economia mista e empresas públicas estão sujeitas ao mesmo regime jurídico das empresas privadas. Desta forma, não cabe à administração indireta a instauração de processos e aplicação de sanções, sob pena de "violação do direito à liberdade de agir e da integridade da pessoa, que somente pode ser restringida pela lei e, no caso de sanção, somente poderá ser aplicada por entidade de direito público".

$\mathrm{O}$ art. $3^{\circ}$ explica que o processo administrativo deverá respeitar o direito ao contraditório e à ampla defesa, com portarias de instauração do processo que indiquem os fatos nos quais é baseado, as normas pertinentes à infração e a sanção cabível. Em seu $\S 1^{\circ}$, o artigo estabelece que a comissão processante será integrada por dois ou mais servidores públicos estáveis, sem explicar, entretanto, como seria dada uma solução em caso de divergência entre eles, se a apuração for feita em número par de servidores ${ }^{440}$.

Traz algumas considerações sobre o acordo de leniência em seu art. $4^{\circ}$, que deverá conter cláusula estipulando que ficarão sem efeito a isenção e a redução da sanção, estabelecida pelo art.16, $\S 2^{\circ}$, da Lei federal n.12.846/13, em caso de descumprimento do acordo, permanecendo válidas as informações e documentos constantes no respectivo procedimento. Foi criado, pelo art.5 $5^{\circ}$ a CEEP (Cadastro Estadual de Empresas Punidas), que reunirá e dará publicidade às sanções aplicadas com base neste decreto.

Assim como na Lei federal, o decreto estadual não determinou maiores especificações sobre como será avaliada a presença ou não de programas de compliance, e nem o que se espera destes programas, persistindo nas mesmas lacunas criticadas na norma anterior.

\subsubsection{Decreto n.55.107, de 13 de maio de 2014}

Mais completo que o decreto estadual, o decreto n.55.107, de 2014, dispõe sobre a responsabilização administrativa e civil de pessoas jurídicas pela prática de atos contra a Administração Pública, no município de São Paulo. Tem por objetivo disciplinar o processo administrativo destinado à apuração da responsabilidade administrativa de

\footnotetext{
${ }^{440}$ SOUZA, Luciano Anderson de. Lei Anticorrupção: balanço de um semestre de muitos desacertos. Boletim IBCCRIM, São Paulo, v. 22, n. 260, jul. 2014. p.11.
} 
pessoas jurídicas pela prática de atos contra a Administração Pública Municipal Direta e Indireta.

A Controladoria Geral do Município foi o órgão escolhido para ser responsável pela instauração da sindicância, de acordo com o art. $3^{\circ}$ do decreto municipal, "fator que empresta segurança, padronização e racionalidade aos procedimentos ${ }^{441}$ ". Para que estes procedimentos do processo tenham início, será necessária uma representação ou denúncia que devem ser "devidamente fundamentadas, contendo a narrativa dos fatos, a indicação da pessoa jurídica envolvida e os indícios concernentes à irregularidade ou ilegalidade imputada".

Diferentemente do decreto estadual, o municipal estabeleceu em seu art. $4^{\mathrm{o}}$ que o processo administrativo para apuração de responsabilidade será conduzido por uma comissão formada por 03 servidores estáveis. No caso do surgimento de indícios de fraude, irregularidades, riscos de dano irreparável ou de difícil reparação, ou mesmo um motivo grave que coloque em risco o interesse público, a autoridade instauradora poderá suspender, cautelarmente, os efeitos do ato ou processo relacionado ao objeto de investigação $\left(\operatorname{art} \cdot 5^{\circ}\right)$.

O decreto determinou o prazo de 180 dias contados da data da publicação do ato para apresentar relatórios que tragam os fatos apurados e a eventual responsabilidade da pessoa jurídica $\left(\operatorname{art} .6^{\circ}\right)$. Para isto, o decreto especificou o procedimento administrativo a ser observado, como as informações do mandado de citação, a produção das provas testemunhais e outras que se julgar necessárias para uma instrução razoável. Uma vez concluído o relatório, que deverá sugerir as sanções que devem ser aplicadas (art.13, $\S 3^{\circ}$ ), este será encaminhado à Procuradoria Geral do Município, para que, no prazo de 10 dias, haja a manifestação jurídica no que se refere o art. $6^{\circ}, \S 2^{\circ}$ da Lei n.12.846/13.

A Lei n.12.846/13 trouxe que a personalidade jurídica pode ser "desconsiderada sempre que utilizada com abuso do direito para facilitar, encobrir ou dissimular a prática dos atos ilícitos previstos nesta lei ou para provocar confusão patrimonial, sendo estendidos todos os efeitos das sanções aplicadas à pessoa jurídica aos seus administradores e sócios com poderes de administração, observados o contraditório e a ampla defesa". O decreto municipal dispõe sobre esta questão em seu art.19, segundo o

\footnotetext{
${ }^{441}$ SOUZA, Luciano Anderson de. Lei Anticorrupção: balanço de um semestre de muitos desacertos. Boletim IBCCRIM, São Paulo, v. 22, n. 260, jul. 2014. p.11.
} 
qual, os administradores e sócios serão "informados sobre a possibilidade de a eles serem estendidos os efeitos sanções que porventura venham a ser aplicadas” às pessoas jurídicas.

$\mathrm{O}$ art. 21 especificou, a partir dos princípios da razoabilidade e da proporcionalidade, que a gravidade da sanção será avaliada considerando o bem jurídico e o interesse social envolvidos (inciso I). A avaliação da vantagem auferida ou pretendida pelo infrator incluirá "os valores recebidos ou que deixaram de ser desembolsados, bem como se houve tratamento preferencial contrário aos princípios e regras da administração pública, a fim de facilitar, agilizar ou acelerar indevidamente a execução de atividades administrativas" (inciso II). Da mesma forma, a análise da cooperação da pessoa jurídica para a apuração das infrações vai considerar a identificação dos demais envolvidos e a obtenção de informações e documentos que comprovem o ilícito sob apuração, ainda que sem um acordo de leniência firmado (inciso VII). O decreto, entretanto, não trouxe maiores explicações sobre as características que se espera dos programas e procedimentos aqui tratados como de conformidade.

A norma municipal ainda estabelece a "possibilidade de socorro ao Ministério Público para fins de se assegurar a indisponibilidade de bens, direitos ou valores necessários à garantia do pagamento da multa ou da reparação integral do dano ${ }^{442,}$.

O decreto n.55.107/14 detalhou melhor os procedimentos a serem observados pela Controladoria Geral nas fases do relatório e na aplicação das sanções, se considerada culpada a pessoa jurídica, assegurando mais garantias para a defesa e contraditório. Delimitou melhor as situações em que estas sanções serão aplicadas, porém também deixou lacunas sobre o que será considerado um programa de conformidade adequado.

\subsubsection{Decreto n. 8240 , de 18 de março de 2015}

O Decreto n.8240/2015 teve por objetivo regulamentar a lei $12.846 / 13$, dispondo sobre a responsabilização administração de pessoas jurídicas pela prática de atos contra a administração pública, nacional ou estrangeiro, dentre outras providências.

\footnotetext{
${ }^{442}$ SOUZA, Luciano Anderson de. Lei Anticorrupção: balanço de um semestre de muitos desacertos. Boletim IBCCRIM, São Paulo, v. 22, n. 260, jul. 2014. p.12.
} 
Sem que tenha havido maiores explicações sobre a forma como as multas serão aplicadas, o Decreto segue a "linha do direito administrativo sancionador, preservando uma perigosa orientação de ultima ratio de intervenção penal, sem maiores reflexões sobre a gravidade do sistema de sanções proposto pela nova lei ${ }^{443}$ ". São previstas como sanções administrativas, em seu Capítulo II, multas, cujo valor será limitado entre $\mathrm{R} \$ 6.000,00$ (seis mil reais) e $\mathrm{R} \$ 60.000 .000,00$ (sessenta milhões de reais), e a publicação extraordinária da decisão sancionadora. $\mathrm{O}$ art.16 assevera que "a pessoa jurídica também estará sujeita a sanções administrativas que tenham como efeito restrição ao direito de participar em licitações ou de celebrar contratos com a administração pública".

O capítulo III reiterou a ideia dos incentivos à colaboração ${ }^{444}$, ao prever em seu art.28 que os acordos de leniência serão celebrados com as pessoas jurídicas responsáveis pelas práticas dos atos lesivos previstos na Lei Anticorrupção e nos ilícitos administrativos trazidos pela Lei n.8666/93, com vistas à isenção ou à atenuação das respectivas sanções, desde que colaborem efetivamente com as investigações e o processo administrativo. Sua estrutura "propõe um ambiente negocial forte comprometido com a colaboração pessoa jurídica-Estado ${ }^{445}$ ", que terá alguns requisitos a serem seguidos, como o fato da empresa ser a primeira a manifestar interesse em cooperar com a apuração do ato lesivo; ter cessado sua participação no ato lesivo antes da data da propositura do acordo; admitir sua participação na infração administrativa; cooperar com as investigações, fornecendo informações, documentos e elementos que comprovem a infração administrativa. Assim como no caso da figura do whistleblower, o clima de denuncismo que pode vir a ser criado no ambiente empresarial causa preocupações, especialmente pelo que dispõe o art.36 ao trazer que as cláusulas e obrigações serão analisados de acordo com o caso concreto. Mais uma vez mostra-se presente a falta de segurança jurídica e de limites pré-estabelecidos para a aplicação de sanções e acordos.

Em seu capítulo IV traz explicações sobre os programas de integridade que consistiriam "no âmbito da pessoa jurídica, no conjunto de mecanismos e procedimentos internos de integridade, auditoria e incentivo à denúncia de irregularidades e na aplicação efetiva de códigos de conduta, políticas e diretrizes com objetivo de detectar e sanar desvios, fraudes, irregularidades e atos ilícitos praticados contra a administração pública,

\footnotetext{
${ }^{443}$ SILVEIRA, Renato de Mello Jorge; SAAD-DINIZ, Eduardo. Compliance, Direito Penal e Lei Anticorrupção. São Paulo: Saraiva, 2015. p.325-326.

${ }^{444}$ SILVEIRA, Renato de Mello Jorge; SAAD-DINIZ, Eduardo. op.cit. p.349.

${ }^{445}$ SILVEIRA, Renato de Mello Jorge; SAAD-DINIZ, Eduardo. op.cit. p.349.
} 
nacional ou estrangeira" (art.41, caput), com "as características e riscos atuais das atividades de cada pessoa jurídica" (art.41, par. único).

Como forma de avaliação dos programas de identidade, o artigo 42, estabelece, dentre outras medidas: o comprometimento da alta direção da pessoa jurídica (inciso I); padrões de conduta, códigos de ética, políticas de integridade aplicáveis a todos os funcionários e terceiros (incisos II e III); treinamentos sobre o programa (inciso IV); análise periódica dos riscos e realização das adaptações necessárias (inciso V); registros contábeis completos (inciso VI); canais de denúncias (inciso X); medidas disciplinares (inciso XI); o monitoramento contínuo (inciso XV) e a transparência em relação a doações políticas (XVI). Nesta avaliação serão consideradas as características particulares de cada empresa $\left(\operatorname{art} .42, \S 1^{\circ}\right)$.

Além da multa administrativa, o Decreto determina que o CEIS (Cadastro Nacional de Empresas Inidôneas e Suspensas) "conterá informações referentes às sanções administrativas impostas a pessoas físicas ou jurídicas que impliquem restrição ao direito de participar de licitações ou de celebrar contratos com a administração pública de qualquer esfera federativa".

Esperava-se que o decreto federal preenchesse as lacunas deixadas pela norma federal e pelos decretos anteriores, mas ainda podemos observar omissões em sua redação. Com multas que podem chegar a ocasionar o fechamento das empresas, a regulação anticorrupção carece de maiores delimitações tanto em seus procedimentos, quanto nos institutos apresentados, como forma de garantir segurança jurídica.

\subsection{Diretrizes e Orientações da soft law e Convenções Internacionais}

\subsubsection{United States Sentencing Guidelines}

O United States Sentencing Guidelines estabeleceu padrões determinados para garantir a efetivação de programas eficazes de compliance, que tiveram um significado efetivo nas percepções corporativas das boas práticas aceitáveis, consideradas na avaliação de sistemas de autorregulação ${ }^{446}$. As Guidelines constituem uma série de fatores e

\footnotetext{
${ }^{446}$ PARKER, Christine. Is there a reliable way to evaluate organizational compliance programs? Disponível em: <http://www.aic.gov.au/media_library/conferences/regulation/parker.pdf $>$. Acesso em 15 de abril de 2015. p.07.
} 
parâmetros considerados no oferecimento, ou não, de acusações contra a empresa ${ }^{447}$, com o intuito de influenciar as empresas para que elas cumpram o verdadeiro "espírito das leis" ${ }^{\prime 448}$.

A análise dos programas de compliance na sentença pode ser visto como um resultado do direito norte-americano considerar empresas como pessoas legais criminalmente responsáveis, especialmente após o caso New York Central and Hudson River Railroad vs. Unites States of America.

Trata-se de um sistema de organização das empresas que coloca em prática a lógica da "cenoura e porrete": para aquelas empresas que tiverem se organizado de uma forma eficiente, com o objetivo de evitar os delitos empresariais em suas atividades, será dada a "cenoura" (aqui em forma de atenuação ou mesmo anistia da pena), enquanto para aquelas mal organizadas, ausentes de controles internos, virá o "porrete" estatal e seu efeito preventivo geral $^{449}$. Após calcular o grau da ofensa cometida para um determinado crime, o USSG analisa o caso específico, aumentando ou diminuindo a gravidade final. Será levado em consideração a gravidade da ofensa e a culpabilidade da organização, sendo fatores agravantes das multas: o envolvimento ou tolerância a atividades criminosas; antecedentes da empresa; outras violações ou obstrução de investigações e da justiça ${ }^{450}$.

Percebe-se ter sido necessário adaptar as Diretrizes para os crimes cometidos pelas empresas, visto que elas não poderiam ser presas, mas seria possível que evitassem práticas delituosas por meio da implementação de programas preventivos planejados de acordo com sua atividade, tamanho e histórico ${ }^{451}$. Para que a empresa tenha um programa efetivo de compliance e ética, ela deverá exercitar as devidas diligências para prevenir e identificar condutas criminosas $(\S 8 \mathrm{~B} 2.1 .1)$, bem com promover uma cultura organizacional que encoraje a conduta ética e o compromisso de estar em compliance com a lei (§8B2.1.2).

\footnotetext{
${ }^{447}$ MORALES ROMERO, Marta Muñoz de. Programas de cumplimiento "efectivos" en la experiência comparada. In: ARROYO ZAPATERO, Luis; NIETO MARTÍN, Adán (org) El derecho penal económico en la era compliance. Valencia: Tirant lo Blanch, 2013.p.222.

${ }^{448}$ WARREN, Danielle E.; GASPAR, Joseph P.; LAUFER, William S. Is formal ethics training merely cosmetic? A study of ethics training and ethical organizational culture. Business Ethics Quartely, vol.24, janeiro de 2014. p.88.

${ }^{449}$ NIETO MARTÍN, Adán. El programa politico-criminal del corporate goverment: derecho penal de la empresa y gobierno corporativo. Revista Aranzadi de derecho y proceso penal, Navarra, n. 11, 2004. p. 268.

${ }^{450}$ HEMPHILL, Thomas A.; CULLARI, Francine. Corporate governance practices: a proposed policy incentive regime to facilitate internal investigations and self-reporting of criminal activities. Journal of Business Ethics, vol.87, supplement 1, Abril de 2009. p.335.

${ }^{451}$ MARTIN, Jay; McCONNELL, Ryan D.; SIMON, Charlotte A. Plan now or pay later: the role of compliance in criminal cases. Houston: Forthcoming UH International Law Journal, 2011.p.20.
} 
As Diretrizes afirmam que eventuais falhas na prevenção e identificação de infrações não significam, necessariamente, que o programa não é efetivo. A empresa deverá, portanto, desenvolver padrões e procedimentos ( $\$ 8 \mathrm{~b} 2.1 . b .1)$ encorajadores de conduta ética que precisam ser de conhecimento, e estarem sob a fiscalização, dos seus executivos (§8b2.1.b.2). Importante ressaltar que a simples adoção de um modelo de prevenção falho pode significar, somente, uma atenuação da responsabilidade da empresa $^{452}$ e, caso não haja uma adequada aplicação e treinamento dos seus funcionários, poderá ser entendido que a empresa não possuía um programa de compliance $^{453}$.

Caberá à empresa tomar as medidas necessárias para assegurar que seu programa de compliance e ética seja seguido, com monitoramento e auditorias (§8b2.1.b.5.a). Da mesma forma, manterá atualizados mecanismos que permitam as denúncias anônimas de condutas ilegais que aconteçam no desenvolvimento de suas atividades (§8b2.1.b.5.c). É possível perceber a preocupação com o desenvolvimento e a manutenção de mecanismos de disciplina apropriados, atualizados, monitorados e corretamente aplicados ${ }^{454}$.

Após a descoberta da conduta criminal, a empresa deverá tomar medidas razoáveis para responder à infração e impedir que semelhantes condutas ocorram novamente (§8b2.1.b.7) utilizando-se, por exemplo, de avaliações de risco e na modificação das cláusulas que não estejam sendo eficientes (\$8b2.1.c). Prevê o "deferred prosecution agreement", um tipo de "transação penal em que a empresa se submete voluntariamente a um período probatório ao longo do qual implementa reformas internas substanciais e coopera com o governo, de maneira efetiva, ajudando os promotores a construir um caso contra os empregados individualmente considerados ${ }^{455}$ ". Estas melhorias podem ser feitas como reformas na condução dos negócios e nos programas de compliance, com a promessa de abster-se de novas condutas ilegais e a monitoração por parte do Departamento de Justiça (DOJ) ${ }^{456}$.

\footnotetext{
${ }^{452}$ MATUS ACUÑA, Jean Pierre. La certificación de los programas de cumplimiento. In: ARROYO ZAPATERO, Luis (dir.). NIETO MARTÍN, Adán (dir.). El derecho penal económico en la era compliance. Valência: Ed. Tirant lo Blanch, 2013. p.149.

${ }^{453}$ MARTIN, Jay; McCONNELL, Ryan D.; SIMON, Charlotte op.cit. p.26.

${ }^{454}$ MARTIN, Jay; McCONNELL, Ryan D.; SIMON, Charlotte A. Plan now or pay later: the role of compliance in criminal cases. Houston: Forthcoming UH International Law Journal, 2011.p.21-22.

${ }^{455}$ TANGERINO, Davi de Paiva Costa. Culpabilidade e responsabilidade penal da pessoa jurídica. Revista Brasileira de Ciências Criminais, São Paulo, v. 18, n. 86, set./out. 2010. p.55.

${ }^{456}$ MARTIN, Jay; McCONNELL, Ryan D.; SIMON, Charlotte A. op.cit.p.43. Os autores explicam que o procedimento a ser realizado pela empresa é separado em seis etapas: a) a empresa admite ter cometido uma infração; b) renuncia ao seu estatuto por um período de tempo (o acordo com o Departamento de Justiça pode
} 
As autoridades norte-americanas reconhecem o esforço de uma empresa em desenvolver um eficiente programa de compliance, medindo a pena através das Sentencing Guidelines, que regulam, detalhadamente, quais as medidas serão consideradas penalmente mitigadoras ${ }^{457}$. As diretrizes valoram a forma de organização das empresas, de acordo com suas especificidades (como tamanho, tipo de atividade), permitindo uma adaptação das exigências e uma maior flexibilidade ${ }^{458}$. Ao mesmo tempo, por representar um sistema de orientação do dimensionamento das penas, buscam harmonizar a prática judicial ${ }^{459}$.

Levando em consideração a cooperação das empresas e sua responsabilidade em elaborar e implementar programas preventivos, a empresa terá conforme mencionado, partindo de uma pena-base, a sanção valorada em sua culpabilidade e no dano social causado $^{460}$. Serão vistos como fatores de redução de pena além de um efetivo programa de compliance, o fato de a empresa ter relatado a violação e aceitar que, de fato, é responsável por ela ${ }^{461}$.

As Diretrizes contam com uma tabela de pontuação de acordo com a culpabilidade da empresa nas condutas realizadas. De acordo com sua $\S 8 \mathrm{C} 2.5$, a empresa começará com cinco pontos aos quais serão agregados novos valores de acordo com: envolvimento ou tolerância com a atividade criminal, onde será considerado o tamanho da empresa, a quantidade de funcionários, se altos executivos tinham conhecimento das condutas irregulares; o histórico da organização, de acordo com ele serão adicionados pontos à condenação se a empresa já houver praticado improbidades anteriormente; também com relação aos antecedentes, será observado se a empresa respeitou os requisitos de um prévio período de prova relacionado ao cometimento de irregularidades anteriores; se a empresa tentou, de alguma forma, impedir ou obstruir a justiça, pontos serão adicionados.

levar de um a cinco anos); c) reconhece o acordo e compromete-se a não mais violar a lei; d) concorda em auxiliar o DOJ a processar os infratores; e) concorda que sua companhia não irá contradizer os termos do acordo.

${ }^{457}$ KUHLEN, Lothar. Cuestiones fundamentales de compliance y derecho penal. In: KUHLEN, Lothar (ed.). MONTIEL, Juan Pablo (ed.). ORTIZ DE URBINA GIMENO, Iñigo (ed.). Compliance y teoria del derecho penal. Madrid: Marcial Pons, 2013. p.59.

${ }^{458}$ NIETO MARTÍN, Adán. El programa político-criminal del corporate goverment: derecho penal de la empresa y gobierno corporativo. Revista Aranzadi de derecho y proceso penal, Navarra, n. 11, 2004. p.269.

${ }^{459}$ BARBOSA, Julianna Nunes Targino. op.cit. p.163.

${ }^{460}$ BARBOSA, Julianna Nunes Targino. op.cit. p.164.

${ }^{461}$ HEMPHILL, Thomas A.; CULLARI, Francine. Corporate governance practices: a proposed policy incentive regime to facilitate internal investigations and self-reporting of criminal activities. Journal of Business Ethics, vol.87, supplement 1, Abril de 2009. p.336. 
Caso a empresa possuísse, no momento dos delitos, um programa de ética e compliance efetivo, conforme mencionado anteriormente, de acordo com a $\S 8 \mathrm{~b} 2.1$, a empresa terá pontos subtraídos de sua pontuação. Entretanto, se a empresa, tendo conhecimento do crime, não comunicar as autoridades competentes, seu programa não será considerado uma atenuante. Para isso, entende o USSG que o indivíduo com responsabilidade operacional pelo programa de compliance tem obrigações de reportar as condutas irregulares à autoridade competente (§8C2.5.f.3.C.i). Pontos também serão subtraídos caso a empresa colabore com as investigações e aceite sua responsabilidade pela conduta criminal. A $\S 8 \mathrm{C} 2.9$ prevê o confisco de ganhos obtidos pela organização que não venham a ser pagos como restituição ou por outras medidas de reparação.

O Departamento de Justiça avaliará o grau de cooperação da empresa de acordo com, por exemplo, a sua disposição em identificar culpados, o esforço em encontrar testemunhas, a completa divulgação dos resultados de investigações internas já realizadas e, até, a renúncia da proteção garantida na relação advogado-cliente ${ }^{462}$. As multas também poderão ser diminuídas se prejudicarem a capacidade da empresa de fazer a restituição das vítimas ou se a empresa não tiver como realizar o mínimo exigido pelas Diretrizes sem que isto prejudique a continuação de suas atividades ( $\$ 8 \mathrm{C} 3.3)$.

A cultura organizacional aplicada por meio dos programas de prevenção será avaliada por padrões determinados pelas Sentencing Guidelines de forma proporcional à atividade, tamanho e complexidade da empresa. Serão também observados a gravidade da ofensa e o grau de culpabilidade da empresa, se esta mantinha um sistema de compliance atualizado e monitorado regularmente, bem como seu histórico e proatividade em reportar a conduta irregular e agir de forma a evitar sua repetição. O elevado grau de mecanicismo que se percebe com as Sentencing Guidelines traz preocupações, uma vez que pode ensejar na conduta empresarial a prática "check the box”, criando um ambiente propício para os programas de compliance de fachada e não significar uma efetiva mudança de comportamento.

${ }^{462}$ HEMPHILL, Thomas A.; CULLARI, Francine. op.cit. p.339. 


\subsubsection{Acordos da Basileia}

Com o fim do acordo de Bretton Woods e com a grande liberalização financeira, em 1974 foi realizado o fórum de discussão que ficou conhecido como Basel Committee on Banking Supervision com o objetivo de "promover uma padronização de regras e procedimentos a serem seguidos pelos bancos atuantes nos seus países membros, fortalecendo a solidez dos mercados financeiros ${ }^{463}$ ".

Buscando reduzir o risco de fracasso dos bancos, garantir liquidez ao Sistema Financeiro Internacional e padronizar normas que seriam utilizadas nas instituições financeiras ${ }^{464}$, o primeiro acordo da Basileia trouxe princípios básicos de prevenção à lavagem de dinheiro para que o dinheiro proveniente resultante de atos ilícitos não fosse misturado ao dinheiro obtido por fontes legais, como as práticas de know your client, identificação de operações financeiras e a cooperação com as autoridades estatais ${ }^{465}$. Exigiu-se, ainda, que os bancos e instituições financeiras garantissem sua solvência com a manutenção de um "mínimo de capital para cobrir os riscos das operações", através de uma "harmonização regulatória" e da distinção dos tipos de ativos de acordo com os riscos $\operatorname{apresentados}^{466}$.

Com o segundo acordo, novas técnicas de supervisão e controle interno para melhor supervisão foram elencadas ${ }^{467}$. O Acordo Basileia II trouxe a necessidade de um "maior detalhamento de classes de riscos de crédito e de mercado", bem como uma "alocação de capital direcionada para os riscos operacionais dos bancos", por meio de uma avaliação regular dos riscos de suas atividades e ativos financeiros ${ }^{468}$. A partir deste momento, os bancos foram expostos ao risco de mercado (value at risk), que se tratava de uma medida que “informava o pior cenário possível em relação à perda máxima provável dentro de um valor referência de probabilidade de ocorrência ${ }^{469}$ ". Fundamentados nos pilares da alocação de capital, supervisão e transparência, os bancos passaram a avaliar seus riscos de acordo com o nível de exposição de suas atividades. O Acordo de Basileia II buscava

\footnotetext{
${ }^{463}$ AMORIM, Thiago Navarro Mafra. Contingência de crises financeiras: um estudo sobre a evolução da regulação dos mercados e o risco das instituições financeiras no Brasil, 2011. p.69-70.

${ }^{464}$ AMORIM, Thiago Navarro Mafra. op.cit. p.70.

${ }^{465}$ CARDOSO, Débora Motta. op.cit. p.23.

${ }^{466}$ AMORIM, Thiago Navarro Mafra. op.cit. p.71.

${ }^{467}$ CARDOSO, Débora Motta. Greco Filho, Vicente. A extensão do compliance no direito penal análise crítica na perspectiva da lei de lavagem de dinheiro. São Paulo: Tese-USP, 2013. p.23.

${ }^{468}$ AMORIM, Thiago Navarro Mafra. op.cit. p. 77.

${ }^{469}$ AMORIM, Thiago Navarro Mafra. op.cit. p.82.
} 
“estimular a criação de metodologias que medissem esses riscos de forma mais precisa, sendo papel do regulador o monitoramento da qualidade dessas provisões ${ }^{470,}$.

Assim como o Basileia II exigia melhor qualidade nas informações divulgadas, para que assim o mercado pudesse avaliar o comportamento e o posicionamento das instituições financeiras $^{471}$, o terceiro acordo da Basileia teve por objetivo aumentar a qualidade, consistência e transparência do mercado ${ }^{472}$. Para alcançar tais metas, é necessário assegurar que todos os riscos sejam captados pelo quadro de investimentos, bem como "aperfeiçoar a capacidade das instituições financeiras de absorver choques, fortalecer a estabilidade dos negócios e a promoção de um crescimento econômico sustentável ${ }^{473 "}$.

Os documentos e processos de avaliação dos riscos deverão estar em adequação com as normas, e, ainda, os bancos devem desenvolver metodologias que os permitam avaliar o risco de crédito envolvido em empréstimos a pessoas físicas e jurídicas, promovendo, desta forma, a integridade do sistema de informações de gestão.

\subsubsection{Convenção Interamericana contra a Corrupção}

As Convenções Internacionais servem como uma forma dos Estados discutirem assuntos e problemas comuns, com o intuito de trocar informações, estabelecer um diálogo e ajustar os dispositivos que serão aplicados em seus ordenamentos. Aquelas que trazem mecanismos de prevenção "referem-se a medidas voltadas a impedir ou obstaculizar os atos preparatórios ou anteriores à prática dos crimes e constituem exemplos pontuais ${ }^{474, "}$.

Aprovada no Brasil por meio do Decreto Legislativo n. 152, de 25 de junho de 2002, a Convenção Interamericana contra a Corrupção determinou ser o combate e a prevenção à corrupção, práticas indispensáveis para os países democráticos, como forma de evitar distorções na economia, vícios na gestão pública e deterioração da moral social.

O texto da Convenção ressalta o uso das práticas corruptivas como instrumentos utilizados pelo crime organizado em âmbito transnacional, reforçando a necessidade da

\footnotetext{
${ }^{470}$ RIBEIRO, Ivan César. Regulação financeira, poder no mercado e crise financeira. Tese (Doutorado em Direito Comercial) - Faculdade de Direito, Universidade de São Paulo, São Paulo, 2012. p.142.

${ }^{471}$ AMORIM, Thiago Navarro Mafra. op.cit. p.86.

${ }^{472}$ Informações obtidas em Basel Committee on Banking Supervision - Basel III: A global regulatory framework for more resilient banks and banking systems. Junho, 2011.

${ }^{473}$ CARDOSO, Débora Motta. op.cit. p.24.

${ }^{474}$ MACHADO, Maíra Rocha. Internacionalização do direito penal. Sāo Paulo: Edesp, 2004. p.36.
} 
cooperação internacional entre os Estados com o objetivo de tomar as medidas adequadas contra as pessoas que cometam atos de corrupção no exercício das funções públicas, prejudicando as atividades comerciais e financeiras (art. II). Como medidas de prevenção são apresentados mecanismos como a implementação e cumprimento de normas de conduta, com a finalidade de prevenir conflitos de interesses e assegurar o adequado uso dos recursos confiados aos funcionários públicos; sistemas para declaração das receitas, ativos e passivos, buscando transparência, equidade e eficiência; formas de proteção a funcionários públicos e cidadãos que denunciarem práticas de corrupção e, também, mecanismos que estimulem a participação da sociedade civil e de organizações nãogovernamentais (art. III).

Maíra Rocha Machado define as medidas de harmonização de legislações nacionais como “a realização, pautada no respeito à pluralidade dos direitos estatais, de uma equivalência de regras nacionais ou, mais precisamente, de uma equivalência de custos e benefícios socioeconômicos ou de situações jurídicas resultantes de sua aplicação ${ }^{475, "}$ Neste sentido, a Convenção sugere que os Estados impulsionem o desenvolvimento e a harmonização das legislações nacionais e a consecução dos objetivos da Convenção com o compromisso de tipificar as práticas de aproveitamento indevido de informações reservadas, privilegiadas ou de bens do Estado ou de empresas em que o funcionário público tenha tido acesso; todas ação ou omissão que resulte em uma decisão com a qual o funcionário obtenha ilicitamente para si ou para outrem, qualquer beneficio ou proveito; e, por último, o desvio de bens móveis ou imóveis, dinheiro ou valores pertencentes ao Estado para fins aos quais não eram destinados (art. XI).

Os Estados-parte deverão prestar ampla assistência para identificar, localizar, bloquear, apreender e confiscar bens obtidos ou provenientes da prática dos delitos tipificados pela Convenção (art. XV), buscando o intercâmbio de experiências por meio de acordos e reuniões entre os órgãos e instituições competentes (art. XIV).

A Convenção Interamericana contra a corrupção evidencia preocupação com a harmonização dos ordenamentos nacionais e a cooperação entre os Estados como forma de fortalecer as políticas desenvolvidas para a prevenção da corrupção, tão prejudicial para as instituições democráticas.

${ }^{475}$ MACHADO, Maíra Rocha. op.cit. p.26. 


\subsubsection{Convenção das Nações Unidas contra a Corrupção}

Contextualizada pelo escândalo de Watergate e pela constatação de que a conduta antiética envolvia cerca de quatrocentas empresas e US\$300 milhões em propinas ${ }^{476}$, a Convenção focou na presença de países cujas leis fossem aplicadas a grandes corporações expostas às oportunidades de corromper funcionários públicos estrangeiros. Representou uma transformação em que Recomendações da OCDE tiveram caráter vinculativo. Ainda que os países tenham liberdade para impor medidas de prevenção aos subornos de acordo com seus ordenamentos internos, não deverão fazê-las por influência de interesses econômicos ${ }^{477}$.

Em seu preâmbulo ${ }^{478}$, a Convenção evidencia sua preocupação com a gravidade dos problemas e os efeitos decorrentes da corrupção, como o enfraquecimento das instituições, dos valores democráticos, da ética e da justiça no Estado de Direito. Reconhece que se trata de uma questão global que ameaça a estabilidade política e o desenvolvimento econômico destes Estados. Suas finalidades foram definidas pelo seu art. $1^{\mathrm{o}}$ : promover e fortalecer as medidas para prevenir e combater mais eficaz e eficientemente à corrupção; promover, facilitar e apoiar a cooperação internacional e a assistência técnica na prevenção e na luta contra a corrupção, bem como promover a integridade, a obrigação de prestar contas e gerir corretamente os bens públicos.

As medidas preventivas envolvem o estabelecimento e o fomento de práticas eficazes contra a corrupção, em conformidade com os princípios fundamentais dos ordenamentos jurídicos de seus Estados parte, com foco na integridade e transparência (art. $5^{\circ}$ ). A Convenção traz a necessidade de códigos de conduta para que funcionários públicos ajam com integridade, honestidade e responsabilidade (art. $8^{\circ}$ ). Ao Estado caberá a função de estabelecer medidas e sistemas que facilitem a denúncia de atos de corrupção às autoridades competentes. Deverá da mesma forma, adotar medidas pautadas pela transparência, como a apresentação de informação sobre gastos, sistemas de contabilidade, auditoria e gestão de riscos, de acordo com sua legislação interna (art. $9^{\circ}$ ).

Em relação ao setor privado, a Convenção estabeleceu que cada Estado "adotará medidas para prevenir a corrupção e melhorar as normas contábeis e de auditoria no setor

\footnotetext{
${ }^{476}$ ROSE, Cecily. International anti-corruption norms: their creation and influence on domestic legal systems. Reino Unido: Oxford University Press, 2015. p.63.

${ }^{477}$ ROSE, Cecily. op.cit. p.67.

${ }^{478}$ OCDE: Convenção das Nações Unidas contra a Corrupção, 2005.
} 
privado, assim como, quando proceder, prever sanções civis, administrativas ou penais eficazes" diante do descumprimento destas (art. 12.1). As medidas deverão promover a cooperação entre os organismos responsáveis pelo cumprimento da lei e as entidades privadas (art. 12.2.a), formulando normas que tenham por objetivo garantir a integridade das entidades privadas, a partir de códigos de conduta e a prevenção de conflitos de interesses; a transparência e a manutenção de livros de registros de acordo com as normas de contabilidade e auditoria (art. 12.3).

Com o propósito de prevenir a lavagem de dinheiro, cada Estado deverá regular e supervisionar os bancos e instituições financeiras, focando na identificação do cliente e, quando possível, no beneficiário final, com registros e denúncias de transações suspeitas (art. 14). O Capítulo III da Convenção trouxe uma série de condutas que devem ser qualificadas como delitos como, por exemplo, o suborno de funcionários públicos nacionais e estrangeiros ${ }^{479}$ (artigos 15 e 16); o tráfico de influências ${ }^{480}$ (art. 18); o enriquecimento $^{\text {ilícito }}{ }^{481}$ (art. 20); o suborno no setor privado $^{482}$ (art. 21); a responsabilidade da pessoa jurídica ${ }^{483}$ (art. 26).

\footnotetext{
${ }^{479}$ Entendido o suborno de funcionários públicos nacionais ou internacionais pela Convenção como "a promessa, o oferecimento ou a concessão a um funcionário público de forma direta ou indireta, de um benefício indevido que redunde em seu próprio proveito ou no de outra pessoa ou entidade com o fim de que tal funcionário atue ou se abstenha de atuar no cumprimento de suas funções oficiais" ou "a solicitação ou aceitação por um funcionário público, de forma direta ou indireta, de um benefício indevido que redunde em seu próprio proveito ou no de outra pessoa ou entidade com o fim de que tal funcionário atue ou se abstenha de atuar no cumprimento de suas funções oficiais (artigos 15 e 16).

${ }^{480}$ Cada Estado Parte considerará a possibilidade de adotar as medidas legislativas e de outras índoles que sejam necessárias para qualificar como delito, quando cometido intencionalmente: a) A promessa, o oferecimento ou a concessão a um funcionário público ou a qualquer outra pessoa, de forma direta ou indireta, de um benefício indevido com o fim de que o funcionário público ou a pessoa abuse de sua influência real ou suposta para obter de uma administração ou autoridade do Estado Parte um benefício indevido que redunde em proveito do instigador original do ato ou de qualquer outra pessoa; b) A solicitação ou aceitação por um funcionário público ou qualquer outra pessoa, de forma direta ou indireta, de um benefício indevido que redunde em seu proveito próprio ou no de outra pessoa com o fim de que o funcionário público ou a pessoa abuse de sua influência real ou suposta para obter de uma administração ou autoridade do Estado Parte um benefício indevido (artigo 18).

${ }^{481}$ Artigo 20. Com sujeição a sua constituição e aos princípios fundamentais de seu ordenamento jurídico, cada Estado Parte considerará a possibilidade de adotar as medidas legislativas e de outras índoles que sejam necessárias para qualificar como delito, quando cometido intencionalmente, o enriquecimento ilícito, ou seja, o incremento significativo do patrimônio de um funcionário público relativos aos seus ingressos legítimos que não podem ser razoavelmente justificados por ele.

${ }^{482}$ Artigo 21. Cada Estado Parte considerará a possibilidade de adotar medidas legislativas e de outras índoles que sejam necessárias para qualificar como delito quando cometido intencionalmente no curso de atividades econômicas, financeiras ou comerciais: a) a promessa, o oferecimento ou a concessão, de forma direta ou indireta, a uma pessoa que dirija uma entidade do setor privado ou cumpra qualquer função nela, de um benefício indevido que redunde em seu próprio proveito ou no de outra pessoa, com o fim de que, faltando ao dever inerente às suas funções, atue ou se abstenha de atuar; b) a solicitação ou aceitação, de forma direta ou indireta, por uma pessoa que dirija uma entidade do setor privado ou cumpra qualquer função nela, de um
} 
Os denunciantes encontram proteção no artigo 33 da Convenção que exige dos Estados que considerem incorporar em seus ordenamentos medidas apropriadas para a proteção daqueles que denunciem às autoridades, de boa fé e com motivos razoáveis, quaisquer feitos relacionados com os delitos previstos neste documento.

A importância de instituições integradas evidencia a dificuldade em prevenir os delitos de corrupção. A cooperação entre organismos nacionais (funcionários e organismos públicos, bem como com os encarregados de investigar e processar judicialmente os delitos) foi recomendada pelo artigo 38, sem deixar em segundo plano a importante participação do setor privado, especialmente das instituições financeiras (art. 39).

Diante da internacionalização das operações e do enfraquecimento das fronteiras, torna-se imperativa uma assistência entre os países com relação às investigações, processos e ações judiciais (art. 46). Neste sentido, cada Estado-parte adotará medidas para que suas instituições financeiras "verifiquem a identidade dos clientes, adotem medidas razoáveis para determinar a identidade dos beneficiários finais dos fundos depositados em contas vultosas e intensifiquem seu escrutínio de toda conta solicitada ou mantida no ou pelo nome de pessoas que desempenhem ou tenham desempenhado funções públicas eminentes e de seus familiares e estreitos colaboradores" (art.52). Este procedimento terá por objetivo descobrir transações suspeitas e informar as autoridades sobre elas.

O Manual de Diretrizes para controles internos, ética e compliance, da OCDE envolve a tomada das devidas diligências, já na escolha dos parceiros de negócios, sua documentação e treinamento adequado de funcionários e altos dirigentes contra a prática de suborno ${ }^{484}$. Apesar de seu caráter não vinculativo, o Manual influenciou o desenvolvimento e aprimoramento de ordenamentos nacionais sobre como as empresas poderia prevenir e combater os subornos e a corrupção ${ }^{485}$. Tem por objetivo o combate e

benefício indevido que redunde em seu próprio proveito ou no de outra pessoa, com o fim de que, faltando ao dever inerente às suas funções, atue ou se abstenha de atuar.

${ }^{483}$ Artigo 26. 1. Cada Estado Parte adotará as medidas que sejam necessárias, em consonância com seus princípios jurídicos, a fim de estabelecer a responsabilidade de pessoas jurídicas por sua participação nos delitos qualificados de acordo com a presente Convenção. 2. Sujeito aos princípios jurídicos do Estado Parte, a responsabilidade das pessoas jurídicas poderá ser de índole penal, civil ou administrativa. 3. Tal responsabilidade existirá sem prejuízo à responsabilidade penal que incumba às pessoas físicas que tenham cometido os delitos. 4. Cada Estado Parte velará em particular para que se imponham sanções penais ou não penais eficazes, proporcionadas e dissuasivas, incluídas sanções monetárias, às pessoas jurídicas consideradas responsáveis de acordo com o presente artigo.

${ }^{484}$ OCDE: Good Practice Guidance on Internal Controls, Ethics and Compliance, 2010.

${ }^{485}$ ROSE, Cecily. International anti-corruption norms: their creation and influence on domestic legal systems. Reino Unido: Oxford University Press, 2015. p.94. 
prevenção do suborno de oficiais públicos estrangeiros estabelece a necessidade das empresas investirem em efetivos controles internos, programas de compliance e avaliação, monitoramento e adaptação dos mecanismos de avaliação dos riscos aos quais a empresa se encontra exposta. 


\section{A PREVENÇÃO AOS CRIMES ECONÔMICOS DENTRO DAS EMPRESAS}

\subsection{Governança Corporativa}

Após graves casos de falhas na contabilidade, as corporações americanas foram forçadas a reconsiderar seus sistemas de governança não só pela legislação federal, mas também por exigências do mercado financeiro ${ }^{486}$, quando ficou estabelecido que os sistemas de governança devem estar atualizados com o desenvolvimento do mercado com o objetivo de evitar manipulações e práticas egoístas dos administradores ${ }^{487}$. Desta forma, as normas de governança precisaram de mudanças, sem que isso ocasionasse gastos desnecessários, nem uma regulação excessiva que prejudicasse a gestão das empresas ${ }^{488}$.

Governança corporativa são mecanismos ou princípios que influenciam o processo decisório dentro de uma empresa, instituídos para fazer com que o controle dela aja em benefício das partes com direitos legais sobre a empresa, minimizando o oportunismo ${ }^{489}$. As empresas, em sua busca pela eficiência econômica, precisam ser administradas por dirigentes competentes e capazes que disponham de suficientes mecanismos de controle e de disponibilização de informação de qualidade ${ }^{490}$.

Em uma realidade em que se separa a propriedade do controle, é necessário que haja um alinhamento dos interesses de ambas as partes. Com o passar do tempo, empresas antes administradas por famílias, buscam profissionais especializados que possam conduzilas da melhor forma possível. A governança opera em muitas dimensões das corporações ${ }^{491}$ e pode ser entendida "como um sistema pelo qual as organizações são

\footnotetext{
${ }^{486}$ BHAGAT, Sanjai; BOLTON, Brian; ROMANO, Roberta. The promise and peril of corporate governance indices. In: OOSTWOUDER, Wilco (ed.). SCHENK, Hans (ed.). Corporate Governance: current issues and the financial crisis. Deventer: Kluwer, 2011. p. 13.

${ }^{487}$ COFFEE JR, John C. What caused Enron? 20 de janeiro de 2003. Columbia Law \& Economics Working Paper n. 214. p. 04.

${ }^{488}$ HOLMSTROM, Bengt; KAPLAN, Steven N. The State of U.S. Corporate Governance: what's right and what's wrong. Finance Working Paper, n.23, 2003.p.02.

${ }^{489}$ CARVALHO, Antonio Gledson. Governança Corporativa no Brasil em perspectiva. In: SILVA, André Luiz Carvalhal da (org); LEAL, Ricardo Pereira Câmara (org). Governança Corporativa: Evidências Empíricas no Brasil. São Paulo: Editora Atlas, 2007. p. 22.

${ }^{490}$ NIETO MARTÍN, Adán. El programa político-criminal del corporate goverment: derecho penal de la empresa y gobierno corporativo. Revista Aranzadi de derecho y proceso penal, Navarra, n. 11, 2004. p.262.

${ }^{491}$ BHAGAT, Sanjai; BOLTON, Brian; ROMANO, Roberta. op.cit. p.41.
} 
dirigidas, monitoradas e incentivadas, envolvendo os relacionamentos entre proprietários, conselho de administração, diretoria, agentes externos e órgãos de controle ${ }^{492, "}$.

Coube à governança corporativa sintetizar valores e modelos a serem seguidos pela gestão empresarial ${ }^{493}$. Boas práticas de governança podem apresentar diversas consequências positivas para a empresa, como maior eficiência na gestão e desempenho; geração de valor para os acionistas; melhora na imagem da companhia; integridade na conduta da empresa sob os aspectos ético, financeiro e normativo; transparência ${ }^{494}$, equidade entre os stakeholders ${ }^{495}$ e maior preocupação com questões relacionadas aos direitos humanos, ambientais e trabalhistas ${ }^{496}$. É composta de mecanismos legais e institucionais destinados a salvaguardar o interesse dos acionistas e reduzir os custos de agência; aumentar as informações disponíveis; monitorar os administradores e reforçar a disciplina do mercado ${ }^{497}$.

A transparência encontra-se intimamente ligada aos deveres de informação que a empresa deve prestar. Tendo em vista a complexidade das atividades e operações realizadas cotidianamente pela empresa, o incremento aos deveres de informação deve ser de forma quantitativa e qualitativa ${ }^{498}$ : a primeira, vinculada à necessidade de transparência e maior volume de informações a serem passadas a todos os stakeholders e, a segunda, para permitir uma maior acessibilidade aos interessados, como, por exemplo, os investidores, para que as atividades e riscos possam ser avaliados racionalmente. Em um contexto em que o segredo oferece mais vantagens para as práticas negociais, "fraudes e

${ }^{492}$ CHAVES, Renato. O cidadão, as grandes corporações e a governança corporativa: cidadania combina com economia? In: FONTES FILHO, Joaquim Rubens (org). LEAL, Ricardo Pereira Câmara (org). O futuro da governança corporativa desafios e novas fronteiras. São Paulo: Saint Paul, 2013. p.93.

${ }^{493}$ LOPES, Marcelo Rodrigo. Governança Corporativa e redução de assimetrias de informação. Faculdade de Direito, Universidade de São Paulo, São Paulo, 2015. p.30.

${ }^{494}$ Por transparência entende-se que "o administrador precisa se empenhar em disponibilizar para todos os sócios e demais interessados as informações relevantes que dizem respeito ao exercício da empresa, não por imposição de leis, regulamentos, códigos ou políticas privadas, mas fundamentalmente buscando criar um clima de confiança interna e externa à empresa". PRADO, Roberta Nioac; VILELA, Renato. Teoria e Prática na governança corporativa: distanciamento das dimensões em função do formalismo. FONTES FILHO, Joaquim Rubens (org). LEAL, Ricardo Pereira Câmara (org). O futuro da governança corporativa desafios e novas fronteiras. São Paulo: Saint Paul, 2013.p.49.

${ }^{495}$ Caracterizada pelo tratamento justo de todos os sócios e demais partes interessadas (stakeholders), deverá ser promovida entre todos aqueles que, direta ou indiretamente, relacionam-se com a sociedade e podem ser por ela afetados. PRADO, Roberta Nioac; VILELA, Renato. Teoria e Prática na governança corporativa: distanciamento das dimensões em função do formalismo. op.cit. p.49.

${ }^{496}$ COIMBRA, Marcelo de Aguiar (org). MANZI, Vanessa Alessi (org). Manual de compliance preservando a boa governança e a integridade das organizações. São Paulo, Atlas, 2010. p.26.

${ }^{497}$ BURNS, Arthur F.; EDWARDS, Franklin R. U.S. Corporate Governance: what went wrong and can it be fixed?. Chicago, 2003.p.03.

${ }^{498}$ NIETO MARTÍN, Adán. El programa político-criminal del corporate goverment: derecho penal de la empresa y gobierno corporativo. Revista Aranzadi de derecho y proceso penal, Navarra, n. 11, 2004. p.270. 
malversações da veracidade das informações podem gerar mais valor do que as políticas baseadas na confiança ${ }^{499,}$.

Constitui governança corporativa a "harmonização dentre os interesses múltiplos acomodados dentro da atividade desempenhada pela empresa ${ }^{500,}$, de forma que possui também como objetivo orientar a tomada de decisões, "a criação e observação de diretrizes empresariais e o monitoramento da implementação destas ${ }^{501}$ ". Para que os interesses das empresas sejam alcançados, há uma necessidade de que as informações sejam corretas e transparentes, para que as decisões possam ser tomadas no melhor interesse dos envolvidos. Conforme afirma Nieto Martín, é necessário que haja equidade e simetria de informações para que todos os participantes do mercado possam ter acesso a informações horizontalmente iguais ${ }^{502}$.

Em um ambiente em que haja assimetria de informações será criado espaço para comportamentos egoístas (moral hazard), além de criar problemas à sinalização dentro da empresa (que, em condições essenciais, facilitaria o relacionamento entre os agentes econômicos envolvidos), à seleção adversa (um ambiente com informações assimétricas gera escolhas e atuações negativamente influenciadas) e problemas de agências (criando dificuldades de harmonização de interesses dentro da estrutura negocial $)^{503}$. O fato de que nem sempre todos os agentes de uma operação terão as mesmas informações faz com que sejam criados espaços para comportamentos oportunistas. A assimetria de informações quando aliada a comportamentos deste tipo pode levar ao colapso de mercados ${ }^{504}$.

Com sua teoria sobre a "Eficiência dos Mercados", Eugene Fama explica que o ideal seria que houvesse um mercado no qual os preços forneçam sinais precisos para a alocação de recursos, ou seja, um mercado onde as empresas podem produzir e tomar decisões e os investidores poderão escolher entre as ações confiando que os preços

\footnotetext{
${ }^{499}$ SAAD-DINIZ, Eduardo. Regulação privada: há ainda alternativas para a prevenção à corrupção e proteção de direitos humanos no âmbito corporativo? In: SAAD-DINIZ, Eduardo (org.); BRODOWSKI, Dominik (org.); SÁ, Ana Luiza de (org.). Regulação do abuso no âmbito corporativo: o papel do direito penal na crise financeira. São Paulo: Editora LiberArs, 2015.p.82.

${ }_{500}$ LOPES, Marcelo Rodrigo. Governança Corporativa e redução de assimetrias de informação. Faculdade de Direito, Universidade de São Paulo, São Paulo, 2015. p.37.

${ }^{501}$ LOPES, Marcelo Rodrigo. op.cit. p.81.

${ }^{502}$ NIETO MARTÍN, Adán. El programa político-criminal del corporate goverment: derecho penal de la empresa y gobierno corporativo. Revista Aranzadi de derecho y proceso penal, Navarra, n. 11, 2004. p.270.

${ }^{503}$ LOPES, Marcelo Rodrigo. op.cit. p.67-81.

${ }^{504}$ RIBEIRO, Ivan César. Regulação financeira, poder no mercado e crise financeira. Tese (Doutorado em Direito Comercial) - Faculdade de Direito, Universidade de São Paulo, São Paulo, 2012. p.43.
} 
refletem integralmente todas as informações disponíveis ${ }^{505}$. A eficiência será um resultado da disponibilidade das mesmas informações a todos os participantes do mercado e que todos estejam de acordo com as implicações das informações atuais nos preços atualizados e distribuição futura ${ }^{506}$. Para George Akerlof, a eficiência do mercado está relacionada com a transparência das informações, para que todas as partes saibam as qualidades e defeitos dos produtos, sendo a assimetria de informações e a desonestidade dos participantes prejudiciais ao mercado ${ }^{507}$. Ainda que o autor afirme que "a dificuldade em distinguir boa e má qualidade seja inerente ao mundo dos negócios ${ }^{508}$ ", é necessário que a todos os players estejam disponíveis informações necessárias para uma tomada de decisão racional.

Nos EUA, John Coffee Jr entende que as principais influências para as mudanças nas políticas de governança corporativa começaram durante os anos 90, com os movimentos de takeover e o crescimento do uso de remunerações em forma de ação para os administradores $^{509}$. Com o seguinte momento de desregulamentação, os administradores começaram a assumir maiores riscos para inflacionar o preço das ações, fazendo com que eles se preocupassem com o valor do dia-a-dia das ações. Tais administradores transferiram seu foco de ganhos moderados para a realização de receitas e os escândalos aumentaram $^{510}$.

Antes dos anos 80, os administradores entendiam que não estavam representando o melhor interesse dos acionistas, mas sim da própria empresa, garantindo o seu crescimento e balanceando os interesses de todos os stakeholders (comunidade, fornecedores, funcionários e também os acionistas). Os incentivos internos como a propriedade de ações e opções por parte dos administradores eram modestos (cerca de $20 \%$ das remunerações dos CEOs estava vinculada à performance no mercado de capitais) ${ }^{511}$. O valor pago aos grandes executivos nos EUA aumentou substancialmente nas últimas décadas, gerando diferentes críticas. Alguns entenderam que este aumento representaria um alinhamento entre os interesses dos CEOs e sua equipe com os anseios dos acionistas, porém para

\footnotetext{
${ }^{505}$ FAMA, Eugene F. Efficient capital markets: a review of theory and empirical work. The Journal of Finance, maio de 1970. p.383.

${ }^{506}$ FAMA, Eugene F. op.cit. p.387.

${ }^{507}$ AKERLOF, George A. The Market for "lemons": quality uncertainty and the market mechanism. Quaterly Journal of Economics, v.LXXXIV, n.3, agosto de 1970. p.388-495.

${ }^{508}$ AKERLOF, George A. op.cit. p.500.

${ }^{509}$ COFFEE JR, John C. What caused Enron? 20 de janeiro de 2003. Columbia Law \& Economics Working Paper n. 214. p.09.

${ }^{510}$ COFFEE JR, John C. op.cit. p. 11.

${ }^{511}$ HOLMSTROM, Bengt; KAPLAN, Steven N. The State of U.S. Corporate Governance: what's right and what's wrong. Finance Working Paper, n.23, 2003.p.03-05.
} 
outros tratava-se de uma transferência não merecida do patrimônio dos acionistas a alguns executivos com poucos efeitos de incentivo. Com este tipo de remuneração, aumentou-se a motivação para que os dados financeiros fossem manipulados com o intuito de inflar os valores das ações ${ }^{512}$.

Por que os administradores se envolvem em esquemas e declaram informações falsas que sabem que serão relevadas eventualmente? No caso Enron, a remuneração dos executivos era intimamente ligada ao shareholder value e grande parte caracterizava-se pelo risco excessivo ${ }^{513}$. Uma alternativa seria o uso de ações mais restritas que não permitissem aos administradores obter vantagens no curto-prazo, incentivando sua transparência e divulgação das informações relacionadas às suas atividades. Neste sentido, seria importante que os diretores e gerentes revelassem e explicassem as razões pelas quais, por exemplo, vendiam suas ações em um momento de compra no mercado ${ }^{514}$.

Uma boa gestão da governança de uma empresa necessita da participação mais ativa dos Conselhos de Administração e dos acionistas, o que aumentou durante a década de 90, quando os mecanismos de governança passaram a ter importância maior. Ao mesmo tempo em que as empresas norte-americanas falhavam em maximizar o seu valor, o mercado de capitais dos EUA tornava-se mais poderoso diante do aumento da participação acionária de grandes instituições. Com o aceite destes investidores, os conselhos administrativos aumentaram o uso de planos de opções de ação quer permitiam aos gestores partilhar o valor criado ao reestruturar as companhias ${ }^{515}$.

Esta estruturação das empresas, conforme afirma John C. Coffee Jr, depende de uma governança corporativa composta por gatekeepers confiáveis ${ }^{516}$. Gatekeepers seriam intermediários que proporcionam a verificação e a certificação dos serviços aos

\footnotetext{
${ }^{512}$ HOLMSTROM, Bengt; KAPLAN, Steven N. The State of U.S. Corporate Governance: what's right and what's wrong. Finance Working Paper, n.23, 2003.p.09-13.

${ }^{513}$ BURNS, Arthur F.; EDWARDS, Franklin R. U.S. Corporate Governance: what went wrong and can it be fixed?. Chicago, 2003. p.09.

${ }^{514}$ BURNS, Arthur F.; EDWARDS, Franklin R. op.cit. p.10.

${ }^{515}$ HOLMSTROM, Bengt; KAPLAN, Steven N. op.cit. p.08.

${ }^{516}$ COFFEE JR, John C. Understanding Enron: It's about the gatekeepers, stupid. 30 de julho de 2002. Columbia Law \& Economics Working Paper n.207. p.04. São considerados gatekeepers, "entidades ou pessoas que operam em campos sensíveis à lavagem de dinheiro, que exerçam atividades em setores comumente usados pelos agentes de mascaramento de bens de origem ilícita (bancos, corretoras de valores, de imóveis, contadores etc.)", "pois atuam ou tem acesso a caminhos e trilhas pelos quais corre o capital oriundo da infração penal". BOTTINI, Pierpaolo Cruz. Política de Combate à Lavagem de dinheiro. In: BADARÓ, Gustavo Henrique; BOTTINI, Pierpaolo Cruz. Lavagem de dinheiro: aspectos penais $e$ processuais penais: comentários à Lei 9.613/1998, com as alterações da Lei 12.683/2012. 2.ed. rev.atual e ampl. São Paulo: Revista dos Tribunais, 2013. p.35.
} 
investidores. Em um contexto em que a governança corporativa tornou-se mais uma forma de concorrência entre as empresas ${ }^{517}$, serviços que possam verificar demonstrações financeiras, avaliar a credibilidade e os prospectos da empresa, passam a ser necessários não só em momentos de crise ${ }^{518}$. Podem ser auditores, agências de análise de risco de crédito, analistas de ações e advogados que zelem pelos interesses dos acionistas ao monitorar, "certificando a exatidão dos relatórios e a legalidade do comportamento corporativo $^{519}$ ".

As práticas de boa governança devem dispender especial atenção aos gatekeepers para que se possa garantir que a atividade empresarial se desenvolva da forma mais correta e transparente ${ }^{520}$. O problema é que as empresas podem não ter interesse em contratar gatekeepers que forneçam avaliações imparciais ${ }^{521}$. Originalmente externos à administração da empresa, os gatekeepers possuíam maior independência do que os atuais compliance officers ${ }^{522}$, porém corria-se o risco de que suas atividades estivessem mais alinhadas aos dirigentes da empresa do que aos investidores e acionistas ${ }^{523}$.

Mais uma vez a importância da transparência nas atividades mostra-se presente, ao passo que cobra-se uma "responsabilidade mais rigorosa pelas declarações incorretas e omissões em documentos e demonstrações financeiras ${ }^{524}$ \%. Portanto, as práticas de governança corporativa adotadas por uma empresa passam a integrar o seu valor no mercado e conforme explica COFFEE JR, "chose the wrong form and if its important you will suffer at the hands of competitors ${ }^{525, "}$

Nesta busca pelo programa de governança ideal, a empresa deverá respeitar o interesse de todos os stakeholders, atuando como um bom governo corporativo não só nas

\footnotetext{
${ }^{517}$ COFFEE JR, John C. The future as history: the prospects for global convergence in corporate governance and its implications. 93, Northwestern University Law Review, 641. 1999. p.10.

${ }^{518}$ COFFEE JR, John C. op.cit. p.05. Para William S Laufer, os gatekeepers seriam inconvenientes para a administração, sendo entendido que seriam necessários somente quando os investidores estivessem inseguros e cautelosos, o que não tende a acontecer nos momentos de especulação. LAUFER, William S. Corporate Bodies and Guilty Minds: The failure of Corporate Criminal Liability. Chicago: University of Chicago Press, 2006. p. 38.

${ }^{519}$ BURNS, Arthur F.; EDWARDS, Franklin R. U.S. Corporate Governance: what went wrong and can it be fixed?. Chicago, 2003. p.06.

${ }^{520}$ NIETO MARTÍN, Adán. Responsabilidad social, gobierno corporativo y autorregulación: sus influencias en el derecho penal de la empresa. Polít. crim., No 5, 2008, A3-5, p.08.

${ }^{521}$ BURNS, Arthur F.; EDWARDS, Franklin R. op.cit. p.15.

${ }^{522}$ CARDOSO, Débora Motta. Greco Filho, Vicente. A extensão do compliance no direito penal análise crítica na perspectiva da lei de lavagem de dinheiro. São Paulo: Tese-USP, 2013. p.64-65.

${ }^{523}$ BURNS, Arthur F.; EDWARDS, Franklin R. op.cit. p.14.

${ }^{524}$ BURNS, Arthur F.; EDWARDS, Franklin R. op.cit. p.17.

${ }^{525}$ COFFEE JR, John C. op.cit. p. 11 .
} 
atividades internas, buscando evitar o abuso de poder dos seus administradores, mas também terá por objetivo conciliar o interesse da empresa com o seu entorno, em uma expressão da responsabilidade social corporativa ${ }^{526}$. Agindo como bons cidadãos corporativos, as empresas precisam atuar de forma responsável com todos os stakeholders, preocupando-se não só com valores financeiros, mas também com o desenvolvimento social e econômico dos locais em que desenvolvem suas atividades ${ }^{527}$. A ligação de mercados, capital e produção facilitou o afrouxamento por parte das empresas das condições de emprego de seus trabalhadores, especialmente em países em desenvolvimento, que são procurados exatamente pelo menor rigor legislativo. Neste contexto, explica Gunther Teubner, que as empresas podem ocupar um papel de destaque em um modelo de confiança, com o desenvolvimento de códigos internos integrados com sistemas legais $^{528}$.

Esta introdução de valores alheios à atividade empresarial, como a proteção do meio ambiente, dos direitos humanos e dos trabalhadores, pode ser vista como uma estratégia de "gestão de legitimidade" para a consolidação da empresa como um ator político evitando, desta forma, os mecanismos de controle estatais ${ }^{529}$. As responsabilidades das empresas podem ser agrupadas em quatro categorias: econômica (necessidade de ser lucrativa); jurídica (agir de acordo com as leis e regulamentações); ética (fazendo o que é certo) e filantrópica (entendida esta categoria mais como uma opção do que algo certo) ${ }^{530}$.

As empresas vão agir de acordo com as expectativas da sociedade, o que vai influenciar suas decisões e delimitações de responsabilidade nos negócios. A responsabilidade social da empresa pode ser entendida como "a obrigação que a empresa assume com a sociedade, maximizando os efeitos positivos sobre ela e minimizando os negativos, incluindo responsabilidades econômicas, legais, éticas e filantrópicas ${ }^{531}$ ".

\footnotetext{
${ }^{526}$ NIETO MARTÍN, Adán. Responsabilidad social, gobierno corporativo y autorregulación: sus influencias en el derecho penal de la empresa. Polít. crim., N 5, 2008, A3-5, p. 02.

${ }^{527}$ NIETO MARTÍN, Adán. El programa politico-criminal del corporate goverment: derecho penal de la empresa y gobierno corporativo. Revista Aranzadi de derecho y proceso penal, Navarra, n. 11, 2004. p.265.

${ }^{528}$ TEUBNER, Gunther. The corporate codes of multinationals: company constitutions beyond corporate governance and co-determination. p.08. Tradução nossa.

${ }^{229}$ MAROTO CALATAYUD, Manuel. Liberalismo vs. Neocorporativismo: los discursos de la autorregulación como discursos legitimantes. In: ARROYO JIMÉNEZ, Luis (dir.); NIETO MARTÍN, Adán (dir). Autorregulación y sanciones. Valladolid: Lex Nova, 2008. p.81.

${ }^{530}$ MATTEN, Dirk; CRANE, Andrew; CHAPPLE, Wendy. Behind the mask: revealing the true face of corporate citizenship. Journal of Business Ethics, vol.45, junho de 2003. p.110.

${ }^{531}$ BORGERTH, Vania Maria da Costa. SOX: entendendo a Lei Sarbanes-Oxley - um caminho para a informação transparente. São Paulo: Cengage Learning, 2008. p.61.
} 
A teoria dos stakeholders argumenta que a empresa possui, sim, responsabilidades não só com os seus acionistas, mas também com todos aqueles que sejam de alguma forma beneficiados ou prejudicados por suas ações empresariais ${ }^{532}$. Por fazerem parte de um contexto social, este movimento de cidadania corporativa se afastaria da voluntariedade e ficaria mais próxima de uma necessária integração nas relações entre a empresa e a sociedade, reforçada pelas exigências de novos atores sociais como, por exemplo, $\mathrm{ONGs}^{533}$. A busca por lucros não pode manter-se como o único e exclusivo objetivo das empresas e para isso as gestões regradas por práticas de governança importantes para uma gestão que busque o equilíbrio entre todos os stakeholders de uma organização.

\subsubsection{Códigos de Governança}

\subsubsection{Código de Governança do IBGC (Instituto Brasileiro de Governança Corporativa)}

Para o Instituo Brasileiro de Governança Corporativa (IBGC), a governança corporativa é "o sistema pelo qual as organizações são dirigidas, monitoradas e incentivas, envolvendo os relacionamentos entre proprietários, Conselho de Administração, Diretoria e órgãos de controle", convertendo princípios em recomendações objetivas, alinhando interesses com a finalidade de preservar e aperfeiçoar o valor da organização, facilitando seu acesso a recursos e contribuindo sua longevidade ${ }^{534}$.

O Conselho de Administração deverá assegurar-se de que a diretoria identifique, preventivamente, e liste os principais riscos aos quais a organização está exposta, sua probabilidade de ocorrência, o impacto financeiro e as medidas e procedimentos adotados para a prevenção (2.3.1).

A auditoria interna terá a responsabilidade de monitorar e avaliar a adequação do ambiente de controle interno e das normas e procedimentos estabelecidos pela gestão (2.33). Para facilitar esta exigência, as atas das reuniões deverão ser redigidas com clareza, mostrando as decisões tomadas, abstenções de voto por conflitos de interesses,

\footnotetext{
${ }^{532}$ MATTEN, Dirk; CRANE, Andrew; CHAPPLE, Wendy. Behind the mask: revealing the true face of corporate citizenship. Journal of Business Ethics, vol.45, junho de 2003. p.110-111.

${ }^{533}$ MATTEN, Dirk; CRANE, Andrew; CHAPPLE, Wendy. op.cit. p. 115.

${ }^{534}$ Informações retiradas da quarta edição do Código de Melhores práticas de governança corporativa, 2009. INSTITUTO BRASILEIRO DE GOVERNANÇA CORPORATIVA. Código das melhores práticas de governança corporativa. 4.ed. São Paulo: IBGC, 2009.
} 
responsabilidades e prazos (2.39). Da mesma forma, toda organização deverá demonstrar suas finanças para um auditor externo independente, para que este possa avaliar se elas refletem adequadamente a realidade da sociedade (4.1).

Em nome da transparência, as empresas deverão divulgar, ao menos em seu website, de forma completa, objetiva, tempestiva e igualitária, relatórios periódicos informando sobre todos os aspectos de sua atividade empresarial, envolvendo questões socioambientais, financeiras, políticas, remuneração dos administradores, riscos existentes e relatos sobre as atividades do Conselho e seus comitês, bem como um detalhamento do modelo de gestão e governança (3.5).

Além de respeitar as leis do país, toda organização deverá ter um Código de Conduta (6.1), que abranja o relacionamento entre conselheiros, diretores, sócios, funcionários, fornecedores e demais stakeholders (6.1.1). A empresa deve enquadrar como violação ao princípio da equidade o uso de informação privilegiada para benefício próprio ou de terceiros (6.3). Para materializar o princípio da transparência, a empresa deverá ter uma política de divulgação de informações que seja completa, objetiva, tempestiva e igualitária (6.5). O Código estabelece que as organizações devem estabelecer uma política de prevenção e combate aos atos ilícitos (6.7).

O IBGC considera a transparência (disponibilização de informações para a manutenção de um clima de confiança), a equidade (tratamento justo a todos os sócios e demais stakeholders) e a prestação de contas (realizada pelos agentes de governança) como os princípios básicos a serem observados pelas empresas.

\subsubsection{Práticas de Governança FEBRABAN}

O Código de Autorregulação bancária criado pela FEBRABAN (Federação Brasileira de Bancos) tem o objetivo de, junto com a sociedade, harmonizar o sistema bancário, suplementando normas e mecanismos de controle de todo o sistema, reconhecendo o dinamismo do mercado e a necessidade de atualização constante de seus procedimentos e padrões de atuação.

Afirma que as normas de autorregulação devem se harmonizar à legislação vigente, às leis e normas relacionadas com o direito do consumidor e direcionadas ao sistema 
bancário e à execução de atividades delegadas pelo setor público às instituições financeiras $\left(\operatorname{art.} 2^{\circ}\right)$. Estas deverão adotar condutas benéficas à sociedade, agindo com ética e legalidade, respeitando o consumidor e fornecendo informações de forma precisa, adequada e clara (art. $\left.5^{\circ}\right)$.

As partes signatárias deverão enviar, quando necessário, relatórios sobre a forma como estão aplicando as normas de autorregulação e seus planos de adequação $\left(\operatorname{art} .9^{\circ}\right)$. Haverá reuniões do Conselho de Autorregulação a quem compete (art.21), entre outras funções, admitir ou suspender partes signatárias; publicar e revisar regras e deliberações para este Código; editar normativos versando sobre assuntos de interesse coletivo; estabelecer diretrizes, políticas e procedimentos do sistema de autorregulação e elaborar um relatório anual contendo resultados alcançados pelo Conselho e pela Diretoria da Autorregulação.

Estabelece um procedimento disciplinar à alguma parte signatária em decorrência da constatação de indício ou violação das normas de autorregulação ou em caso da verificação de inadequação no Relatório de Conformidade (art.33). Na apresentação da defesa a signatária poderá encaminhar uma proposta de celebração de termo de compromisso, comprometendo-se a cessar ou corrigir seus atos (art.37), cuja aceitação será apreciada pelo Conselho Disciplinar. Este termo somente poderá ser celebrado uma vez e não importará a confissão quanto à matéria de fato nem o reconhecimento do fato.

Em caso de condenação a parte signatária estará sujeita a recomendação do Comitê Disciplinar para o ajuste de sua conduta, que poderá ser cumulada com a obrigação de pagar uma contribuição entre uma e dez vezes o valor da menor anuidade paga por uma Associada da Febraban (art.42). Também será impedida de utilizar o Selo da Autorregulação e a perda de seu Conselheiro no Conselho de Autorregulação.

Este Código de Autorregulação tem por objetivo incentivar e integrar as boas práticas no sistema bancário. Ciente da complexidade e do dinamismo de suas operações, estabelece avaliações constantes por parte de suas instituições signatárias, possibilitando aos bancos que ajam da forma mais correta, fortalecendo, assim, sua relação com a sociedade. 


\subsubsection{Níveis de governança corporativa e o novo mercado da Bolsa de Valores de São Paulo (Bovespa)}

No Brasil, a partir das mudanças dos anos 90, como o aumento da competitividade decorrente da maior estabilidade econômica e da abertura do mercado que levaram as empresas brasileiras a uma necessidade crescente de acesso aos mercados de capitais nacionais e internacionais, "a necessidade de obtenção de recursos de menor custo possível tem motivado as empresas a adotar novas práticas de governança corporativa, principalmente nos aspectos de maior consideração dos interesses dos acionistas minoritários, maior transparência das informações ao mercado e profissionalização do conselho de administração ${ }^{535}$ ". O Novo Mercado foi inspirado no Neuer Markt alemão, que trouxe novas regras restritivas para as empresas, como a publicação de demonstrativos trimestrais seguindo padrões contábeis internacionais; submissão a um código de takeover; garantia de liquidez para as ações, que somente são emitidas como ordinárias, dentre outras $^{536}$. Tal prática faz com o preço das ações das empresas que optem pelo Neuer Markt seja maior e, portanto, mais vantajoso.

É de extrema importância que o mercado apresente visibilidade, transparência, acesso e responsabilidade social, segundo explica Raymundo Magliano. Desta forma, promove-se a democratização do mercado, uma vez que o Novo Mercado trata-se de um segmento especial de governança em que todos são detentores das mesmas ações ${ }^{537}$. Promove-se um ambiente de credibilidade, essencial para o bom funcionamento da Bolsa, pois é conduzida com regras claras, eficientes e equânimes para todos os investidores ${ }^{538}$.

A inserção do Novo Mercado estabeleceu regras mais rígidas para as empresas e permitiu "a popularização do acesso ao mercado de capitais, com a educação dos

\footnotetext{
${ }^{535}$ SILVEIRA, Alexandre Di Miceli da. Governança corporativa desempenho e valor da empresa no Brasil. São Paulo, Saint Paul, 2009. p.58.

${ }^{536}$ CARVALHO, Antonio Gledson. Governança Corporativa no Brasil em perspectiva. In: SILVA, André Luiz Carvalhal da (org); LEAL, Ricardo Pereira Câmara (org). Governança Corporativa: Evidências Empiricas no Brasil. São Paulo: Editora Atlas, 2007. p. 37.

${ }^{537}$ MAGLIANO, Raymundo. Mercado de Capitais, Poder Econômico e Regulação. In: FERRAZ JUNIOR, Tercio Sampaio (org). SALOMÃO FILHO, Calixto (org). NUSDEO, Fábio (org). Poder econômico direito, pobreza, violência, corrupção. Barueri, SP, Manole, 2009. p. 13.

${ }^{538}$ MAGLIANO, Raymundo. op.cit. p. 13.
} 
trabalhadores, sua inclusão no Conselho da Bovespa e a criação de diversos clubes de investimentos 539 ,

A criação dos níveis 1 e 2 de governança corporativa e o Novo Mercado da Bovespa busca destacar as empresas comprometidas com maior transparência e melhores práticas de governança corporativa, sendo a adesão voluntária, com um contrato firmado entre as partes ${ }^{540}$. A adesão é voluntária e é concretizada com a assinatura de um contrato entre a companhia, seus controladores, administradores e a BM\&FBOVESPA, segundo o qual as partes acordam em cumprir o Regulamento da Listagem do Novo Mercado e adotam a arbitragem para a solução de eventuais conflitos societários. O contrato é imprescindível, pois torna obrigatório o cumprimento dos requisitos do Novo Mercado, tendo a Bovespa o dever de fiscalizar e, se necessário, punir os infratores ${ }^{541}$.

A arbitragem é vista como uma importante vantagem, pois, desta forma, "os investidores tem a certeza de que quaisquer recursos serão julgados rapidamente e com a devida competência, livrando-os da tradicional morosidade do judiciário ${ }^{542 \%}$. Participam da câmara a companhia listada no Novo Mercado, seus controladores, acionistas em geral, administradores, membros do Conselho Fiscal e a Bolsa ${ }^{543}$. Entretanto, críticos entendem que a arbitragem, ainda que traga vantagens relacionadas à agilidade e rapidez da solução das controvérsias, “em longo prazo impedirá avanços alcançados em outros sistemas que apresentam mecanismos para a publicidade de informações sobre as disputas societárias e resultará em uma grande barreira ao desenvolvimento do mercado de capitais e da governança $^{544, "}$

A arbitragem, considerando o sigilo estabelecido pelas regras da Câmara de Arbitragem do Mercado da BM\&FBOVESPA, "obsta acesso a características relevantes dos conflitos societários, deixando o mercado sem uma das principais fontes de informação

\footnotetext{
${ }^{539}$ SALOMÃO FILHO, Calixto. Desigualdade econômica e insuficiência regulatória. In: FERRAZ JUNIOR, Tercio Sampaio (org). SALOMÃO FILHO, Calixto (org). NUSDEO, Fábio (org). Poder econômico direito, pobreza, violência, corrupção. Barueri, SP, Manole, 2009. p.53.

${ }^{540}$ SILVEIRA, Alexandre Di Miceli da. op.cit. p. 61.

${ }^{541}$ BM\&FBOVESPA. Novo Mercado: Governança Corporativa. Disponível em: < http://www.bmfbovespa.com.br/pt-br/a-bmfbovespa/download/Folder_NovoMercado.pdf $>$. Acesso em 10 de fevereiro de 2015. p. 04.

${ }^{542}$ CARVALHO, Antonio Gledson. Governança Corporativa no Brasil em perspectiva. In: SILVA, André Luiz Carvalhal da (org); LEAL, Ricardo Pereira Câmara (org). Governança Corporativa: Evidências Empíricas no Brasil. São Paulo: Editora Atlas, 2007. p. 37.

${ }^{543}$ BM\&FBOVESPA. op.cit. p. 09.

${ }^{544}$ GORGA, Érica. Arbitragem, governança corporativa e retrocesso no mercado de capitais brasileiro. In: FONTES FILHO, Joaquim Rubens (org). LEAL, Ricardo Pereira Câmara (org). O futuro da governança corporativa desafios e novas fronteiras. São Paulo: Saint Paul, 2013. p.219.
} 
existentes $^{545 \%}$, uma vez que o acesso a informações descobertas nas investigações seria de grande utilidade para estudar e entender práticas de governança que acertaram ou falharam $^{546}$.

A transparência aparece como uma das principais regras para a vinculação aos níveis de governança, assim como a qualidade e divulgação das informações. A transparência aparece, inclusive, como um dos medidores da qualidade da governança de uma empresa, considerando-se três atributos: a data da divulgação dos relatórios financeiros, a utilização de padrões internacionais de contabilidade e a qualidade da firma de auditoria ${ }^{547}$.

O Novo Mercado funciona como um selo de qualidade, porém, reconhecendo que as regras estabelecidas para ele são bastante restritivas e que muitas empresas não teriam condições, a Bovespa optou pela criação de dois novos níveis de governança: Nível 1 e Nível $2^{548}$. A companhia deverá, além de outras medidas, elaborar, divulgar e enviar à Bovespa um código de conduta em que estejam estabelecidos os valores e princípios que orientam a Companhia e que devem ser preservados no seu relacionamento com os administradores, funcionários, prestadores de serviço e demais pessoas e entidades relacionadas à empresa.

\subsubsection{Conselhos de Administração}

Os Conselhos de Administração possuem um dever de assegurar que as informações e os sistemas de relatórios sejam precisos e confiáveis para que as decisões tomadas pela empresa sejam bem fundamentadas ${ }^{549}$. Desta forma, podem assegurar que as estratégias da organização fazem sentido, que há um saudável ambiente interno contando

\footnotetext{
${ }^{545}$ GORGA, Érica. op.cit. p. 219.

${ }^{546}$ As razões mais utilizadas para o sigilo no procedimento arbitral "são as mesmas que levam as partes a solicitá-lo no processo judicial, como a possibilidade de o litígio envolver segredo comercial ou de indústria ou elementos contábeis que não convêm ou que thes seria danoso revelar para conhecimento do público ou de competidores". GORGA, Érica. op.cit. p.226.

${ }^{547}$ SILVA, André Luiz Carvalhal da; LEAL, Ricardo Pereira Câmara. Índice de Governança Corporativa, Valor e Desempenho da Firma no Brasil. In: SILVA, André Luiz Carvalhal da (org); LEAL, Ricardo Pereira Câmara (org). Governança Corporativa: Evidências Empiricas no Brasil. São Paulo: Editora Atlas, 2007. p. 135.

${ }^{548}$ CARVALHO, Antonio Gledson. Governança Corporativa no Brasil em perspectiva. In: SILVA, André Luiz Carvalhal da (org); LEAL, Ricardo Pereira Câmara (org). Governança Corporativa: Evidências Empíricas no Brasil. São Paulo: Editora Atlas, 2007. p. 38.

${ }^{549}$ ROSEN, Robert Eli. Risk Management and Corporate Governance: The Case of Enron. 35 Connecticut Law Ver. 2003. p.1170.
} 
com um efetivo controle das infraestruturas e que os riscos foram avaliados e estão sob controle $^{550}$.

Para Silva Sánchez, o Conselho de Administração possui um dever institucional de evitar delitos que cheguem a seu conhecimento ${ }^{551}$. Grandes empresas tornaram-se tão complexas que poucos são os funcionários que dominam todas as técnicas e métodos utilizados $^{552}$. Por esta razão, um Conselho mais ativo exigirá dos gerentes e administradores das empresas que elaborem melhor as propostas financeiras, aquisições de outras empresas ou mesmo planos de remuneração, garantindo uma melhor gestão dos interesses dos acionistas ${ }^{553}$. Com esquemas de remuneração baseada em ações e precárias políticas de transparência feitas para manipular resultados financeiros, os Conselhos precisam ser especialmente diligentes em relação às suas funções de vigilância e monitoração ${ }^{554}$.

Há a crítica de que ampliar o papel de guardiões aos membros do Conselho pode inibir ou mesmo entrar em conflito com outros papéis que eles devem desenvolver ${ }^{555}$. Porém, juntamente com o dever de analisar as questões de negócios ${ }^{556}$, o conselho deve ter a capacidade de analisar os riscos envolvidos e reportados pelo gerenciamento ${ }^{557}$. Uma importante função dos Conselhos é balancear e mediar os diversos interesses, competitivos e conflitantes, dos diferentes stakeholders da empresa ${ }^{558}$.

Os casos da Enron e WorldCom demonstram que os Conselhos não contavam com membros independentes suficientes, ou que estes falharam em suas funções de supervisão. A independência dos membros é vista como um esforço para eliminar conflitos de interesse, e no caso Enron, ainda que ao menos $86 \%$ do seu Conselho pudessem ser

\footnotetext{
${ }^{550}$ STEINBERG, Richard M. Governance, Risk Management and Compliance: it can't happen to us avoiding corporate disaster while driving success. New Jersey: John Wiley \& Sons, 2011. p.68.

${ }^{551}$ SILVA SÁNCHEZ, Jesús María. Fundamentos del derecho penal de la empresa. Montevideo: B. de F., 2013. p. 187.

${ }^{552}$ LAVELLE, Louis. How governance rules failed at Enron. Bloomberg Business, 20 de janeiro de 2002.

${ }^{553}$ CLARK, Robert Charles. Corporate Governance changes in the wake of the Sarbanes-Oxley Act: a morality tale for policymakers too. Harvard Law and Economics Discussion, n.525, 2005.p.20.

${ }^{554}$ BURNS, Arthur F.; EDWARDS, Franklin R. U.S. Corporate Governance: what went wrong and can it be fixed?. Chicago, 2003.p.12.

${ }^{555}$ CLARK, Robert Charles. op.cit. p.18.

${ }^{556}$ CLARK, Robert Charles. op.cit. p.19.

${ }^{557}$ ROSEN, Robert Eli. Risk Management and Corporate Governance: The Case of Enron. 35 Connecticut Law Ver. 2003. p.1176.

${ }^{558}$ STOUT, Lynn. The Shareholder Value Myth: how putting shareholders first harms investors, corporations and the public. São Francisco, EUA: Berrett-Kochler Publishers, 2012. p.09.
} 
considerados independentes, isso não fez com que os riscos e falhas de governança fossem corretamente avaliados $^{559}$.

Nas palavras de Fergunson, Conselhos compostos por velhos camaradas do CEO, são "muitas vezes completos ignorantes, escolhidos em grande medida para não fazer marola ${ }^{560 »}$ e, desta forma, não desempenham corretamente suas funções de vigilância. Conselhos efetivos devem contar com autonomia suficiente para que possam assegurar os valores e cultura da empresa, criticando e discordando dos administradores, se necessário ${ }^{561}$. Busca-se, então, adaptar os Conselhos de acordo com "características pessoais e profissionais para o cargo que ocupam, que gozem de independência que lhes permita julgar, questionar e denunciar, sempre que necessários ${ }^{562 \%}$.

Importante que os membros do Conselho sigam com performances críticas mesmo quando a empresa aparentar estar em um bom momento ${ }^{563}$. A função dos membros de um Conselho também vai envolver a assistência e o conselhos para um direcionamento das atividades da empresa ${ }^{564}$.

As novas práticas de governança demandam maior responsabilidade para os membros do Conselho, que deverão supervisionar os administradores de forma mais inquisitiva, participando ativamente das decisões e das atividades cotidianas, bem como agindo de forma independente, mas integrada. Devera manter-se atualizado dos projetos e riscos, promover novas politicas para a empresa e demonstrar seus deveres de lealdade e cuidado.

\footnotetext{
${ }^{559}$ BURNS, Arthur F.; EDWARDS, Franklin R. U.S. Corporate Governance: what went wrong and can it be fixed?. Chicago, 2003.p.11.

${ }^{560}$ FERGUNSON, Charles H. O sequestro da América: como as corporações financeiras corromperam os Estados Unidos. Rio de Janeiro: Jorge Zahar Editor Ltda, 2012.p.93.

${ }^{561}$ STEINBERG, Richard M. Governance, Risk Management and Compliance: it can't happen to us avoiding corporate disaster while driving success. New Jersey: John Wiley \& Sons, 2011. p.157.

${ }^{562}$ BORGERTH, Vania Maria da Costa. SOX: entendendo a Lei Sarbanes-Oxley - um caminho para a informação transparente. São Paulo: Cengage Learning, 2008.p.70.

${ }^{563}$ HOLMSTROM, Bengt; KAPLAN, Steven N. The State of U.S. Corporate Governance: what's right and what's wrong. Finance Working Paper, n.23, 2003.p.17.

${ }^{564}$ STEINBERG, Richard M. op.cit. p. 159.
} 


\subsection{Gerenciamento de Riscos}

Os riscos são inerentes às práticas comerciais ${ }^{565}$. A questão é que a produção sistêmica de riscos e a necessidade de uma avaliação adequada fazem com que seja essencial um gerenciamento dos riscos empresarias, para precaução e adaptação da empresa, de acordo com a atividade desenvolvida ${ }^{566}$. O Estado não possui conhecimento suficiente para analisar e controlar os riscos de todos os setores e atividades empresariais, razão pela qual este déficit de responsabilidade estatal deve ser assumido pelas empresas $^{567}$.

Ciente de suas atividades e, consequentemente, dos riscos gerados por elas, caberá às empresas atuar de forma preventiva, dando especial atenção às áreas que possam criar maiores e mais graves riscos à empresa e à coletividade. A empresa deverá avaliar os setores de sua atividade que sejam mais suscetíveis à criação de riscos não permitidos, com o objetivo de proteger bens jurídicos, ou ao menos reduzi-los de forma razoável ${ }^{568}$. Na avaliação dos riscos realizada pela empresa, seria necessário não só detectá-los, mas valorá-los e apresentar respostas convenientes ao valor do dano ${ }^{569}$. A adoção de medidas necessárias para a contenção dos riscos detectados é necessária em cada posto de trabalho, começando pela seleção adequada de cada trabalhador a ocupa-los ${ }^{570}$.

O gerenciamento dos riscos controlam as fronteiras entre os interesses da corporação e do ambiente em que ela se encontra ${ }^{571}$. Os executivos responsáveis analisam diversos tipos de riscos, financeiros, ambientais, jurídicos, sociais, entre outros, e as decisões dependem da administração destes riscos e não na sua total eliminação ${ }^{572}$. Diante da divulgação dos prováveis riscos de uma determinada empresa ou instituição financeira,

\footnotetext{
${ }^{565}$ STEINBERG, Richard M. Governance, Risk Management and Compliance: it can't happen to us avoiding corporate disaster while driving success. New Jersey: John Wiley \& Sons, 2011. p.71.

${ }^{566}$ GÓMEZ-JARA DÍEZ, Carlos. op.cit. p.30.

${ }^{567}$ GÓMEZ-JARA DÍEZ, Carlos. op.cit. p.30.

${ }^{568}$ NIETO MARTÍN, Adán. Responsabilidad social, gobierno corporativo y autorregulación: sus influencias en el derecho penal de la empresa. Polít. crim., No 5, 2008, A3-5, p.10.

${ }^{569}$ COCA VILA, Ivó. ¿Programas de cumplimiento como forma de autorregulación regulada? In: MONTANER FERNÁNDEZ, Raquel (coord.). Criminalidad de empresa y compliance. Prevención y reacciones corporativas. Barcelona: Atelier, 2013. p.57.

${ }^{570}$ COCA VILA, Ivó. op.cit. p.57.

${ }^{571}$ ROSEN, Robert Eli. Risk Management and Corporate Governance: The Case of Enron. 35 Connecticut Law Ver. 2003. p.1171.

${ }^{572}$ ROSEN, Robert Eli. op.cit. p.1169.
} 
por exemplo, caberá aos investidores a interpretação das informações e da confiança na gerência destes riscos por parte dos administradores ${ }^{573}$.

Entende-se por risco sistêmico aquele que "corresponde ao componente não diversificável de risco, inerente à conjuntura econômica, política e social, e que impacta de forma abrangente todos os agentes atuantes em uma dada economia”. Já o risco não sistêmico trata-se de um componente de risco específico do ativo e do contexto específico em que ele se insere como, por exemplo, a descoberta do pré-sal que pode influenciar uma série de ativos relacionados a este contexto específico ${ }^{574}$.

São exemplos de riscos para as empresas as operações fora do balanço (quando ativos e passivos não aparecem no balanço patrimonial corrente); os riscos de liquidez (aqui entendido como o "descasamento entre ativos e passivos que cria a possibilidade da instituição não possuir recursos para cumprir suas obrigações previamente assumidas"); os riscos de insolvência (nos quais os recursos próprios do intermediário financeiros são insuficientes para cobrir suas perdas) e os riscos tecnológicos e operacionais (a possibilidade de perdas devido a falhas humanas, em sistemas ou processos) ${ }^{575}$.

Silva Sánchez enumera algumas práticas, mais especificamente dinâmicas de grupo, que carregariam uma potencialidade criminógena, como aquelas que acrescentariam outras motivações próprias da organização empresarial, por exemplo, concepções erradas de lealdade e solidariedade, cegueira em relação às consequências do simples cumprimento de ordens e a desorganização progressiva de uma empresa que se orienta, unicamente, ao lucro e que pode gerar características informais de conduta que subestimem os riscos das atividades empresariais $^{576}$.

Para uma adequada avaliação dos riscos é necessário que as informações dentro da empresa circulem de forma transparente, de modo que o gerenciamento possa ser feito de forma racional. Por exemplo, grandes empresas multinacionais demandarão atenção diferente a depender do local em que suas filiais se encontram sediadas, seja em um país marcado por uma regulamentação ambiental mais fraca ou em outro local marcado pela corrupção. Cada região, cada ordenamento jurídico exigirá da empresa um gerenciamento

\footnotetext{
${ }^{573}$ AMORIM, Thiago Navarro Mafra. Contingência de crises financeiras: um estudo sobre a evolução da regulação dos mercados e o risco das instituições financeiras no Brasil, 2011. p.41.

${ }^{574}$ AMORIM, Thiago Navarro Mafra. op.cit. p.40-41.

${ }^{575}$ AMORIM, Thiago Navarro Mafra. op.cit. p.42.

${ }^{576}$ SILVA SÁNCHEZ, Jesús María. Fundamentos del derecho penal de la empresa. Montevideo: B. de F., 2013. p.170.
} 
dos riscos aos quais estará exposta. Assim, caberá as empresas que implementem politicas de prevenção e gerenciamento de riscos que levem em consideração erros passados e potenciais eventos que possam vir a ocorrer no futuro ${ }^{577}$.

Se tomarmos como exemplo a grave crise de 2008, explicada neste trabalho a partir do caso Lehman Brothers, perceberemos que uma série de riscos desmedidos por vários personagens determinantes elevaram a questão para uma crise mundial. A falta de análise por parte dos consumidores, que não liam corretamente seus contratos; dos operadores que ignoravam a importância de uma correta avaliação dos riscos; executivos preocupados com ganhos de curto prazo apostaram de forma irresponsável recursos das empresas; as infundadas avaliações dadas pelas agências de rating; os contratos de seguros vistos como "bombas-relógio" por não considerarem riscos de inadimplência e mesmo erros de regulação ${ }^{578}$.

Além dos riscos derivados de suas próprias atividades, a empresa deverá por meio de códigos de conduta, administrar as normativas aplicáveis a sua atividade e implementar condutas que as respeitem e cumpram ${ }^{579}$.Entretanto, a empresa pode ter avaliado os riscos que julgou necessários e ainda assim acontecimentos inesperados aconteçam. Uma previsão pode ter resultados ruins ou péssimos, e isto vai depender da organização interna empresarial e sua capacidade de lidar com as consequências e reverter os danos causados $^{580}$. Neste caso, algumas medidas podem ser tomadas para mitigar as consequências: antecipar o problema e informar os consumidores e demais interessados que medidas já estão sendo tomadas pela empresa; atualizar relatórios; assegurar que seus administradores estejam cientes dos fatos relevantes e agir sempre bde forma proativa para informar e mostrar soluções ${ }^{581}$.

A empresa deve esforçar-se para mostrar que busca resolver o problema, uma vez que a credibilidade da empresa pode ser bastante afetada por condutas desonestas e oportunistas de seus administradores. Para isto, um plano de conduta bem desenvolvido

\footnotetext{
${ }^{577}$ STEINBERG, Richard M. Governance, Risk Management and Compliance: it can't happen to us avoiding corporate disaster while driving success. New Jersey: John Wiley \& Sons, 2011. p.80.

${ }^{578}$ STEINBERG, Richard M. op.cit. p.61-63.

${ }^{579}$ PITT, Harvey. GROSKAUFMANIS, Karl. When bad things happen to good companies: a crisis management primer. Cardozo Law Review. 15, 951, Jan. 1, 1994. p.04-05.

${ }^{580}$ STEINBERG, Richard M. op.cit. p.77.

${ }^{581}$ PITT, Harvey. GROSKAUFMANIS, Karl. op.cit. p.06-07.
} 
previamente vai auxiliar bastante a empresa a encontrar a direção correta em um momento delicado $^{582}$.

As empresas, bancos e instituições financeiras lidam cotidianamente com riscos, por esta razão, precisam ter instrumentos e conhecimento dos riscos que fazem parte de suas atividades e saber como controlá-los. Para isto é necessária uma integração entre administradores, Conselhos e funcionários para que a informação circule e seja possível realizar uma avaliação eficiente.

\subsection{Programas de Compliance}

Os programas de compliance estão relacionados com uma prática empresarial que tem por objetivo estabelecer padrões internos de acordo com as exigências normativas ${ }^{583}$ de forma a exercitar o devido controle e fazer com que proibições penais sejam respeitadas no exercício da atividade social ${ }^{584}$. Em um contexto de crimes corporativos, surge a dúvida se as empresas conseguiriam mudar práticas consolidadas do mercado por culturas de integridade e transparência ${ }^{585}$.

Antes caracterizada por regras pouco observadas, não ajustadas aos verdadeiros riscos da atividade empresarial e pouco elaboradas, as práticas de compliance exercem, atualmente, um papel fundamental dentro das empresas, bem distribuído por todas as áreas e fortalecido pela presença dos compliance officers, auditorias internas e Códigos adaptados às exigências empresariais.

Estas práticas representam uma nova fase do Direito, especialmente do direito penal, fundamentada na prevenção de condutas prejudiciais e numa lógica que passa a responsabilizar empresas envolvidas em atos corruptores, por exemplo ${ }^{586}$. Uma maior

\footnotetext{
${ }^{582}$ STEINBERG, Richard M. Governance, Risk Management and Compliance: it can't happen to us avoiding corporate disaster while driving success. New Jersey: John Wiley \& Sons, 2011. p.199.

${ }^{583}$ SILVEIRA, Renato de Mello Jorge; SAAD-DINIZ, Eduardo. Compliance, Direito Penal e Lei Anticorrupção. São Paulo: Saraiva, 2015. p.65.

${ }^{584}$ LASCURAÍN, Juan Antonio. Compliance, debido control y unos refrescos. In: ARROYO ZAPATERO, Luis (dir.). NIETO MARTÍN, Adán (dir.). El derecho penal económico en la era compliance. Valência: Ed. Tirant lo Blanch, 2013.p.112.

${ }^{585}$ WARREN, Danielle E.; GASPAR, Joseph P.; LAUFER, William S. Is formal ethics training merely cosmetic? A study of ethics training and ethical organizational culture. Business Ethics Quartely, vol.24, janeiro de 2014. p.86.

${ }^{586}$ SILVEIRA, Renato de Mello Jorge. Ponderações sobre o compliance criminal. Valor Econômico, 01 de julho de 2014.
} 
necessidade de transparência e confiabilidade nos negócios realizados à distância e sem pessoalidade ${ }^{587}$, junto com o avanço tecnológico das empresas e a implementação de diferentes práticas empresariais evidenciaram a dificuldade do Estado em exercer o devido controle sobre tais atividades, e juntamente com as mudanças no direito penal, passou-se a exigir que as empresas demonstrem efetiva vontade de manterem-se fora do âmbito delinquencial $^{588}$.

As empresas não possuem interesse em ter problemas com a justiça e para evitar uma exposição negativa que pode impactar seriamente suas atividades, vão definir novas expectativas éticas. Diante do papel dominante das grandes corporações e de suas complexas estruturas organizativas e modelos de gestão, o Estado perde seu papel centralizador e muda sua estratégia reguladora ao se deparar diante de sua incapacidade de regular, supervisionar e sancionar os âmbitos empresariais complexos ${ }^{589}$. Assim como às empresas e instituições financeiras, ao Estado não interessa sofrer consequências econômicas pela falta de prevenção ${ }^{590}$. Para Lothar Kuhlen, estas medidas são tomadas pelas empresas para assegurar que sejam cumpridas as regras vigentes a elas e a seus funcionários e garantir que as infrações descobertas sejam eventualmente sancionadas ${ }^{591}$.

A crescente importância dos programas de compliance, ainda que não seja novidade ${ }^{592}$, destaca a necessidade do desenvolvimento de um programa que seja adequado aos padrões (atividade, tamanho, produção) de cada empresa e que seja eficaz na prevenção de atividades criminosas no âmbito empresarial. Diferentes formas de compliance devem ser introduzidas em diferentes sistemas de governança, com o objetivo de monitorar os mais diversos abusos ${ }^{593}$ e sua adequação será decorrente tanto da configuração inicial, quanto da aplicação, atualização e execução ${ }^{594}$.

\footnotetext{
${ }^{587}$ CARDOSO, Débora Motta. Greco Filho, Vicente. A extensão do compliance no direito penal análise crítica na perspectiva da lei de lavagem de dinheiro. São Paulo: Tese-USP, 2013. p.13.

${ }^{588}$ SILVEIRA, Renato de Mello Jorge; SAAD-DINIZ, Eduardo. Compliance, Direito Penal e Lei Anticorrupção. São Paulo: Saraiva, 2015. p.70-74.

${ }^{589}$ COCA VILA, Ivó. ¿Programas de cumplimiento como forma de autorregulación regulada? In: MONTANER FERNÁNDEZ, Raquel (coord.). Criminalidad de empresa y compliance. Prevención y reacciones corporativas. Barcelona: Atelier, 2013. p.46-47.

${ }^{590}$ CARDOSO, Débora Motta. op.cit. p.32.

${ }^{591}$ KUHLEN, Lothar. Cuestiones fundamentales de compliance y derecho penal. In: KUHLEN, Lothar (ed.). MONTIEL, Juan Pablo (ed.). ORTIZ DE URBINA GIMENO, Iñigo (ed.). Compliance y teoria del derecho penal. Madrid: Marcial Pons, 2013. p.51.

${ }^{592}$ KUHLEN, Lothar. op.cit. p.51.

${ }^{593}$ COFFEE JR, John C. The theory of corporate scandals: why the U.S. and Europe differ. Columbia Law and Economics, Working Paper n.274, mar. 2005. p. 18-19. John Coffee Jr, neste artigo, estabelece algumas situações que poderiam facilitar a ocorrência de escândalos corporativos como, por exemplo, fraudes que
} 
Por ocupar uma posição de intermédio entre o Estado e as práticas em conformidade ao direito $^{595}$, a própria empresa seria o melhor agente para determinar os riscos decorrentes de sua atividade e propor soluções ${ }^{596}$. Para isso, introduziram em seus organogramas mecanismos de controle que buscam evitar responsabilidades penais, seguindo princípios como a separação de poderes e sua independência (distintos departamentos realizando diversos atos empresariais); a documentação dos atos realizados na atividade empresarial; a congruência e coerência das operações (e suas contrapartidas); a transparência da gestão; o cumprimento das normas de bom governo e a confidencialidade ${ }^{597}$.

William Laufer divide a evolução da regulação estatal nas práticas de compliance em quatro partes: na primeira, as cortes estariam obcecadas pela importância e pelo significado da personalidade corporativa, uma vez que havia uma tendência individualista na common law; em seguida, diante da necessidade de um controle social mais forte e formal, ganha forças uma maior regulação das corporações, na medida em que tais empresas se tornam mais descentralizadas; na terceira fase, nota-se claras regras de responsabilização derivadas da doutrina americana de tort law, fazendo com que, as práticas de compliance substituíssem a cultura de punição e, em último, a quarta fase viria com as diretrizes trazidas pelas Sentencing Guidelines para organizações que tinham por objetivo fazer com que as empresas enfrentassem a ameaça de uma punição significativa e, ao mesmo tempo, pudessem se beneficiar de reduções de pena, leniências e perdões

ocorrem em sistemas de propriedade dispersa, características do mercado norte-americano; a pressão para que as empresas divulgassem taxas maiores de crescimento, durante os anos 90, não foi acompanhada de uma mudança compensatória nas práticas que previssem prejudiciais incentivos criados pelas opções de ações; da mesma forma, o pagamento do CEO com opções de ações da empresa também é visto pelo autor como um fator que poderia fazer com que ele pensasse mais em benefício próprio do que na empresa, através de técnicas de manipulação do valor das ações no curto prazo, razão pela qual ele cita a importância dos acionistas controladores europeus que teriam interesses em longo prazo. Neste sentido, Christine Parker e Vibeke Nielsen afirmam que a administração das práticas de compliance, na prática, será fortemente influenciada pelo nível de competência gerencial e recursos disponíveis. PARKER, Christine; NIELSEN, Vibeke Lehmann. Corporate Compliance Systems: could they make any difference? Administration and Society n.41, December, 2008. p.09.

${ }^{594}$ COCA VILA, Ivó. ¿Programas de cumplimiento como forma de autorregulación regulada? In: MONTANER FERNÁNDEZ, Raquel (coord.). Criminalidad de empresa y compliance. Prevención y reacciones corporativas. Barcelona: Atelier, 2013. p.62.

${ }^{595}$ KUHLEN, Lothar. Cuestiones fundamentales de compliance y derecho penal. In: KUHLEN, Lothar (ed.). MONTIEL, Juan Pablo (ed.). ORTIZ DE URBINA GIMENO, Iñigo (ed.). Compliance y teoria del derecho penal. Madrid: Marcial Pons, 2013. p. 68.

${ }^{596}$ COCA VILA, Ivó. op.cit. p.61.

${ }^{597}$ GÓMEZ MARTÌN, Victor. Compliance y derechos de los trabajadores. In: KUHLEN, Lothar (ed.). MONTIEL, Juan Pablo (ed.). ORTIZ DE URBINA GIMENO, Iñigo (ed.). Compliance y teoria del derecho penal. Madrid: Marcial Pons, 2013.p.128. 
judiciais, caso cooperassem com as investigações e demonstrassem um compromisso com as práticas de prevenção ${ }^{598}$.

O resultado foi um novo campo de regulações e reforços legislativos, no qual, o governo ofereceu às organizações a opção de parceria no controle e prevenção de crimes econômicos, na medida em que se aumentou a importância das práticas de compliance com leis e novas regulações, estimuladas por medidas proativas de prevenção a atos ilegais e antiéticos que alinham os interesses governamentais e corporativos para o bom desenvolvimento das atividades econômicas ${ }^{599}$.

$\mathrm{Na}$ visão de Silva Sánchez, as práticas de compliance implicariam uma autorregulação empresarial com a qual o Estado exigiria que a própria empresa controlasse seus riscos e prevenisse infrações ao ordenamento que poderiam ser causados por sua atividade econômica ${ }^{600}$. Esta autorregulação estaria relacionada com a correção dos déficits de organização que abririam caminho para os crimes econômicos, conforme explicaremos a seguir.

Para Nieto Martín, os sistemas de cumprimento constituiriam sistemas de controle sociais e empresariais que ajudariam o Estado e o direito penal em sua tarefa de controlar a criminalidade $^{601}$. O autor compara os programas de compliance com um rio abastecido por diversos afluentes: o primeiro seria a influência derivada da legislação relacionada à prevenção dos riscos laborais, da lavagem de dinheiro e do abuso do mercado, bem como da proteção de dados, que determinaram a obrigação da adoção de controles internos com o objetivo de prevenir determinadas infrações; o segundo afluente seria os governos corporativos, representando um caráter constitucional dentro da própria empresa, com sistemas de decisões democráticas, programas de check and balance, e a ampla participação dos stakeholders; em terceiro lugar, viria a grande influência dos códigos

\footnotetext{
${ }^{598}$ LAUFER, William; GEIS, Gilbert. Corporate crime and a new brand of cooperative regulation. p.139143.

${ }^{599}$ LAUFER, William; GEIS, Gilbert. op.cit. p.145.

${ }^{600}$ SILVEIRA, Renato de Mello Jorge; SAAD-DINIZ, Eduardo. Prólogo. Compliance, Direito Penal e Lei Anticorrupção. São Paulo: Saraiva, 2015. p.15 e ss.

${ }^{601}$ NIETO MARTÍN, Adán. Problemas fundamentales del cumplimiento normative en el derecho penal. In: KUHLEN, Lothar (ed.). MONTIEL, Juan Pablo (ed.). ORTIZ DE URBINA GIMENO, Iñigo (ed.). Compliance y teoria del derecho penal. Madrid: Marcial Pons, 2013. p.21.
} 
éticos de conduta, cujo corpo normativo envolveria todo o sistema empresarial de compliance $e^{602}$.

Parte do objetivo dos programas de compliance é incentivar culturas de prevenção que vão além da simples imposição de deveres de vigilância, tendo por objetivo mais amplo evitar delitos dentro da empresa. A escolha dos comportamentos considerados adequados deveria ir além do mínimo indicado pelas regulações, mas seriam aqueles que realmente mostrassem a importância de valores éticos ${ }^{603}$.

Sua implantação constituiria um dever jurídico-penal reforçado como forma de organizar a vigilância dentro das atividades cotidianas ${ }^{604}$ e seria dirigida a todos os funcionários da empresa, incluídos aqui os altos dirigentes cujos comportamentos corretos seriam importantes para a instauração de um ético ambiente dentro da corporação ${ }^{605}$. Práticas de due diligence demonstrariam da mesma forma, o empenho da empresa em agir de forma correta, garantindo o compromisso em agir dentro da lei ${ }^{606}$.

A cultura de compliance seria baseada na interiorização da necessidade para que as atividades da empresa respeitem o ordenamento jurídico, em todos os seus níveis, a partir de sistemas de documentação e comunicação altamente sofisticados; no estabelecimento de objetivos empresariais e metas de compliance individuais e harmonizadas; na avaliação de riscos de acordo com as atividades realizadas; a delimitação dos âmbitos de competência, com uma clara delimitação das posições de garantia para que se saiba, com precisão, o responsável por cada processo da empresa; e, também, por sistemas internos de comunicação $^{607}$.

Em nome do progresso, os ordenamentos jurídicos toleram certos riscos decorrentes da ação humana, porém quanto maior a probabilidade da produção de danos pela

${ }^{602}$ NIETO MARTÍN, Adán. Problemas fundamentales del cumplimiento normative en el derecho penal. In: KUHLEN, Lothar (ed.). MONTIEL, Juan Pablo (ed.). ORTIZ DE URBINA GIMENO, Iñigo (ed.). Compliance y teoria del derecho penal. Madrid: Marcial Pons, 2013. p.22-25.

${ }^{603}$ WARREN, Danielle E.; GASPAR, Joseph P.; LAUFER, William S. Is formal ethics training merely cosmetic? A study of ethics training and ethical organizational culture. Business Ethics Quartely, vol.24, janeiro de 2014. p.89.

${ }^{604}$ SILVA SÁNCHEZ, Jesús María. Fundamentos del derecho penal de la empresa. Montevideo: B. de F., 2013. p.193-196.

${ }^{605}$ MORALES ROMERO, Marta Muñoz de. Programas de cumplimiento "efectivos" en la experiência comparada. In: ARROYO ZAPATERO, Luis; NIETO MARTÍN, Adán (org) El derecho penal económico en la era compliance. Valencia: Tirant lo Blanch, 2013. p.224.

${ }^{606}$ MORALES ROMERO, Marta Muñoz de. op.cit. p.225.

${ }^{607}$ COCA VILA, Ivó. ¿Programas de cumplimiento como forma de autorregulación regulada? In: MONTANER FERNÁNDEZ, Raquel (coord.). Criminalidad de empresa y compliance. Prevención y reacciones corporativas. Barcelona: Atelier, 2013. p.56-58. 
inobservância das regras, maiores serão as medidas de prevenção adotadas ${ }^{608}$. O sistema de regulação estatal impõe deveres de colaboração aos sistemas de regulação privada ${ }^{609}$, onde a autorregulação das empresas pode ser um mecanismo bastante efetivo, sobretudo em relação aos conhecimentos especiais da empresa e seu domínio dos meios de regulação centrais para a prevenção da criminalidade ${ }^{610}$. A lei, entretanto, pode criar incentivos distorcidos ao oferecer às corporações uma redução das sanções diante da existência de programas de compliance ${ }^{611}$.

Segundo William Laufer, estamos diante de um jogo em que "os incentivos não são estabelecidos para mudar o comportamento corporativo, a cultura empresarial ou a tomada de decisão da corporação", mas constituem uma "indústria de compliance e ética" cujo objetivo é o dinheiro e uma pretensa proteção moral aplicada dentro do mercado ${ }^{612}$. Não há efetivamente padrões que tragam garantias de que o dinheiro aplicado nos programas de compliance mude o comportamento e a forma como o mercado e as empresas realizam suas decisões.

Ulrich Sieber cita alguns elementos dos programas de compliance que poderiam evitar a criminalidade da empresa e, por fim, contra a empresa ${ }^{613}$ : a definição das finalidades e valores a serem observados pela empresa; a responsabilidade do plano de direção fundamentado e os objetivos e procedimentos para evitar a criminalidade; a criação de um sistema de informação para a descoberta e esclarecimento de delitos; a introdução de controladores externos; medidas efetivas de incentivo para o desenvolvimento das medidas de prevenção e o estabelecimento de medidas sancionatórias internas em face dos abusos.

Entende Lawrence Sherman que se deve avaliar se os programas permitem a redução da criminalidade, dos fatores de risco e se aumentam os fatores de proteção a

\footnotetext{
${ }^{608}$ BOCK, Dennis. Compliance y deberes de vigilancia en la empresa. In: KUHLEN, Lothar (ed.). MONTIEL, Juan Pablo (ed.). ORTIZ DE URBINA GIMENO, Iñigo (ed.). Compliance y teoria del derecho penal. Madrid: Marcial Pons, 2013.p. 112.

${ }^{609}$ SIEBER, Ulrich. op.cit. p.300.

${ }^{610}$ SIEBER, Ulrich. op.cit. p.311.

${ }^{611}$ WELLNER, Philip A. Effective compliance programs and corporate criminal prosecutions. Cardozo Law Review. New York, vol.27-1.Outubro de 2005. p.498.

${ }^{612}$ LAUFER, William S. O compliance game. In: SAAD-DINIZ, Eduardo (org.); BRODOWSKI, Dominik (org.); SÁ, Ana Luiza de (org.). Regulação do abuso no âmbito corporativo: o papel do direito penal na crise financeira. São Paulo: Editora LiberArs, 2015.p.59.

${ }^{613}$ SIEBER, Ulrich. op.cit. p. 298.
} 
partir dos programas adotados para prevenção ${ }^{614}$. Evidências podem demonstrar a efetividade dos métodos adotados, a correlação entre o programa de prevenção do crime e os fatores de risco em um determinado período, bem como a sequência temporal entre o programa e o crime ou risco ${ }^{615}$.

Conforme mencionado, a busca por inovações nos programas de governança e compliance, que traria mudanças importantes para a cultura corporativa, não pode ser tratada como um simples produto de mercado ${ }^{616}$. Um bom programa de compliance não é somente uma declaração simbólica que a empresa está comprometida em agir de acordo com a lei, mas um conjunto de ações dos administradores que buscam identificar, corrigir e prevenir irregularidades ${ }^{617}$. Recomendações éticas são inseridas nos códigos de conduta das empresas e as práticas de compliance passam a funcionar como um instrumento de reforço à prevenção de atividades criminosas ${ }^{618}$.

O problema dos programas de compliance, de acordo com Philip WELLNER, está em um desenvolvimento "de fachada" (window-dressing), uma vez que quanto mais efetivo o programa, maiores serão as chances de a empresa descobrir as violações e agir conforme a lei ${ }^{619}$. Quando da aplicação da redução das sanções, o autor encontra duas fraquezas: a criação de uma aplicação da lei excessiva e a necessidade, por parte da empresa, de ter que escolher entre estar em compliance com a lei ou com o espírito da $1 \mathrm{e}^{620}$. As empresas precisam estar autorizadas a implementar programas que estejam de acordo com suas necessidades específicas e a lei, no caso a U.S. Sentencing Guidelines, as obrigaria a escolher entre conceber um programa que melhor impedisse os crimes ou estar de acordo com as características exigidas em lei ${ }^{621}$. A mesma crítica é apresentada por

\footnotetext{
${ }^{614}$ SHERMAN, Lawrence et al. Preventing crime: what works, what doesn't, what's promising. National Institute of Justice, 1998. p. 02.

${ }^{615}$ SHERMAN, Lawrence et al. op.cit. p. 04.

${ }^{616}$ SAAD-DINIZ, Eduardo. Escândalos de corrupção corporativa: filme de terror sem fim?. Boletim IBCCRIM, São Paulo, v. 23, n. 274, set. 2015. p. 11.

${ }^{617}$ PARKER, Christine; NIELSEN, Vibeke Lehmann. Corporate Compliance Systems: could they make any difference? Administration and Society n.41, December, 2008. p.02.

${ }^{618}$ SILVEIRA, Renato de Mello Jorge; SAAD-DINIZ, Eduardo. Compliance, Direito Penal e Lei Anticorrupção. São Paulo: Saraiva, 2015. p.119.

${ }^{619}$ WELLNER, Philip A. op.cit. p.511.

${ }^{620}$ WELLNER, Philip A. op.cit. p.510.

${ }^{621}$ WELLNER, Philip A. op.cit. p.513.
} 
Thomas Rotsch, quando afirma que as empresas adotam departamentos de compliance de forma absolutamente desproporcionada ${ }^{622}$.

Infelizmente, poucos são os estudos empíricos que demonstrem se estes programas conseguem realmente reduzir tais infrações dentro das empresas ou se estas os possuem para, por exemplo, conquistar uma melhor reputação e colocam em prática apenas programas de fachada ${ }^{623}$. Para William S. Laufer, na perspectiva de algumas empresas, bastaria adquirir um programa de compliance suficiente para que a empresa seguisse com suas atividades com um mínimo regulatório para escapar da responsabilização ${ }^{624}$. As empresas seriam incentivadas a adotar programas que não reduzem verdadeiramente as violações, mas as sanções, em caso de condenações ${ }^{625}$. Entretanto, as regulações não foram desenhadas baseadas em evidências de efetividade, mas o sistema ofereceu uma "fachada atraente" para seus participantes, convencendo a todos que bastaria demonstrar uma preocupação com a integridade corporativa ${ }^{626}$.

Para Wellner, a saída mais eficaz seria analisar a cultura e o comportamento da empresa a partir de um fato específico, e não com uma lista de verificação de características pré-determinadas $^{627}$. As cortes deveriam confiar em evidências construtivas, no sentido de fatos, circunstâncias, condutas e intenções da empresa ${ }^{628}$. Aqui estaria evidenciada a fraqueza da lei, que debilita a persuasão e credibilidade regulatória, especialmente diante de um sistema poroso e descentralizado ${ }^{629}$, no qual empresas gastam bilhões anualmente com o objetivo de estar "em conformidade com a lei", e ainda, não serem poucos os casos de crimes econômicos. Desta forma, as agências reguladoras, criadas para controlar os maus comportamentos corporativos, não conseguiriam exercer o

\footnotetext{
${ }^{622}$ ROTSCH, Thomas. Criminal compliance. InDret Revista para el análisis del derecho. Barcelona, jan., 2012. p.04.

${ }^{623}$ SIEBER, Ulrich. ENGELHART, Marc. Compliance Programs for the prevention of economic crimes: an empirical survey of german companies. Berlim: Duncker \& Humblot, 2014. p.02.

${ }^{624}$ LAUFER, William S. Corporate Bodies and Guilty Minds: The failure of Corporate Criminal Liability. Chicago: University of Chicago Press, 2006. p.101.

${ }^{625}$ WELLNER, Philip A. op.cit. p.515. Empresas que cooperem e forneçam informações ao governo, acesso à testemunhas e a informações privilegiadas, possuem uma chance maior de evitar as acusações que uma empresa sem esta cooperação receberiam. LAUFER, William S. Corporate Bodies and Guilty Minds: The failure of Corporate Criminal Liability. Chicago: University of Chicago Press, 2006. p.101.

${ }^{626}$ LAUFER, William S. O compliance game. In: SAAD-DINIZ, Eduardo (org.); BRODOWSKI, Dominik (org.); SÁ, Ana Luiza de (org.). Regulação do abuso no âmbito corporativo: o papel do direito penal na crise financeira. São Paulo: Editora LiberArs, 2015.p.60.

${ }^{627}$ WELLNER, Philip A. op.cit. p.523.

${ }^{628}$ LAUFER, William S. Corporate Bodies and Guilty Minds: The failure of Corporate Criminal Liability. Chicago: University of Chicago Press, 2006. p.71.

${ }^{629}$ LAUFER, William S. op.cit. p.05.
} 
seu papel ${ }^{630}$. Por exemplo, no Brasil, os números apresentados pelo Coaf evidenciam a falta de estrutura para analisar toda a informação recebida ${ }^{631}$.

Christine Parker e Vibeke Nielsen, ao analisarem diversas empresas, afirmam que estudos demonstraram que melhores controles administrativos internos e cultura de compliance são os fatores que condicionam melhores performances dos programas de prevenção ${ }^{632}$. O importante mostra ser a forma como os procedimentos éticos e preventivos são colocados em prática, nas tomadas de decisões cotidianas, e não apenas a existência formal deles. As boas práticas cotidianas influenciam diretamente o bom funcionamento do compliance e os reguladores encontram-se mal equipados para encontrar diferenças entre programas efetivos e inefetivos ${ }^{633}$. Na pesquisa feita pelos autores, com cerca de 300 empresas, cujos questionários foram respondidos por diferentes funcionários, analisou-se medidas que incluíam elementos de implementação de um sistema formal de administração como a percepção dos valores empresariais compartilhados que podem variar de acordo com o indivíduo ou grupo da organização; sistemas formais de administração de práticas de compliance e valores de compliance e a implementação de um sistema que permita a identificação e prevenção de problemas, bem como a correta aplicação dele nas decisões cotidianas $^{634}$.

Foram analisados elementos como a existência de registros de reclamações feitas por clientes, competidores e fornecedores; a busca pela opinião destes stakeholders; cursos para estar de acordo com as exigências regulatórias, com seminários e programas de treinamento e auditores externos ${ }^{635}$. Os resultados mostram que apesar das críticas de que os programas de compliance seriam apenas pedaços de papel, os dados mostraram que o programa é de grande importância para o gerenciamento na prática, por indicar um primeiro passo no comprometimento da empresa com a cultura de compliance. Também

\footnotetext{
${ }^{630}$ LAUFER, William S. op.cit. p.29.

${ }^{631}$ BOTTINI, Pierpaolo Cruz. Política de Combate à Lavagem de dinheiro. In: BADARÓ, Gustavo Henrique; BOTTINI, Pierpaolo Cruz. Lavagem de dinheiro: aspectos penais e processuais penais: comentários à Lei 9.613/1998, com as alterações da Lei 12.683/2012. 2.ed. rev.atual e ampl. São Paulo: Revista dos Tribunais, 2013. p.44.

${ }^{632}$ PARKER, Christine; NIELSEN, Vibeke Lehmann. Corporate Compliance Systems: could they make any difference? Administration and Society n.41, December, 2008. p.04. Controles internos podem ser definidos pela "totalidade das políticas e procedimentos instituídos pela instituição financeira, para assegurar que os riscos inerentes às suas atividades sejam reconhecidos e administrados corretamente". CARDOSO, Débora Motta. Greco Filho, Vicente. A extensão do compliance no direito penal análise crítica na perspectiva da lei de lavagem de dinheiro. São Paulo: Tese-USP, 2013. p.41.

${ }^{633}$ PARKER, Christine; NIELSEN, Vibeke Lehmann. op.cit. p.06.

${ }^{634}$ PARKER, Christine; NIELSEN, Vibeke Lehmann. op.cit. p.13-16.

${ }^{635}$ PARKER, Christine; NIELSEN, Vibeke Lehmann. op.cit. p.14.
} 
resultou importante que a empresa disponibilizasse recursos para a contratação de funcionários qualificados que cooperem com um efetivo gerenciamento de compliance. Da mesma forma, um bom programa de compliance envolveria consultores independentes para avaliar os sistemas e, assim, evidenciar a preocupação da empresa com as boas práticas $^{636}$.

Não é o objetivo dos programas de compliance evitar que as empresas sejam castigadas por um delito contra o meio ambiente, por exemplo, mas sim que estejam de acordo com a legislação ambiental ${ }^{637}$. Cabe aos códigos éticos delimitar as condutas proibidas e quais as normas de comportamento a serem seguidas dentro da empresa. A existência de uma cultura corporativa cuja administração adote e se comprometa com a integridade organizacional minimizaria as preocupações com a honestidade desses programas de compliance ${ }^{638}$. Entende-se que uma efetiva cultura de compliance envolva valores, atitudes e organização administrativa e que sistemas formais não trazem fórmulas simples para conquistar mudanças nos hábitos e práticas cotidianos no gerenciamento das empresas $^{639}$.

A integridade nas atividades representa uma condição necessária e suficiente para que a empresa atinja o máximo de seu desempenho, uma vez que demonstrará que age nos domínios da moralidade, ética e legalidade ${ }^{640}$. Quando uma empresa declara que age de acordo com os preceitos legais exigidos, seus acionistas, funcionários, consumidores acreditam e confiam nesta informação. Assim, os stakeholders criam uma expectativa de padrões a ser seguidos pela empresa e seus dirigentes, que deverão manter sua palavra, cumprir as exigências do Código de Ética e não se envolver em más práticas e delitos corporativos $^{641}$. É importante que se reconheça que os bons valores são refletidos não só no

\footnotetext{
${ }^{636}$ PARKER, Christine; NIELSEN, Vibeke Lehmann. Corporate Compliance Systems: could they make any difference? Administration and Society n.41, December, 2008. p.23-24.

${ }^{637}$ NIETO MARTÍN, Adán. Problemas fundamentales del cumplimiento normative en el derecho penal. In: KUHLEN, Lothar (ed.). MONTIEL, Juan Pablo (ed.). ORTIZ DE URBINA GIMENO, Iñigo (ed.). Compliance y teoria del derecho penal. Madrid: Marcial Pons, 2013. p.27.

${ }^{638}$ LAUFER, William; GEIS, Gilbert. Corporate crime and a new brand of cooperative regulation. p. 147.

${ }^{639}$ PARKER, Christine; NIELSEN, Vibeke Lehmann. op.cit. p.26.

${ }^{640}$ ERHARD, Werner; JENSEN, Michael C.; ZAFFRON, Steve. Integrity: a positive model that incorporates the normative phenomena of morality, ethics and legality. p. 29.

${ }^{641}$ ERHARD, Werner; JENSEN, Michael C.; ZAFFRON, Steve. op.cit. p.65-72.
} 
mercado, mas também dentro do ambiente empresarial e, portanto, sem integridade não é possível atingir um bom desempenho ${ }^{642}$.

Os programas de criminal compliance podem ser entendidos como o somatório de medidas que buscam assegurar a adesão das atividades da empresa às regulações legais ${ }^{643}$, com o objetivo de trazer ética ao ambiente empresarial, fundamentados na ideia de prevenção e não em uma mentalidade meramente repressora ${ }^{644}$. Seriam especialmente adequados para a prevenção dos crimes econômicos em razão de seu conteúdo específico $^{645}$ e integrados por códigos de conduta, de integridade e responsabilidade social corporativa.

Parker por entender que "os reguladores e stakeholders devem ser capazes de avaliar a qualidade dos programas de compliance e sua performance", desenvolve para tal, um método dividido em três etapas: na primeira, a administração deve adotar um projeto para assegurar a implementação de um sistema de compliance; na segunda, os reguladores vão precisar satisfazer que esta autorregulação seja adequadamente implementada no contexto particular de sua empresa e a terceira servirá para avaliar a performance do programa ${ }^{646}$. Considerando que as medidas legais geralmente surgem após a ocorrência de ações erradas, indicadores apropriados nos processos de gerenciamento podem auxiliar no entendimento do por que apareceram brechas e como elas poderiam ser evitadas e corrigidas $^{647}$. A autora acredita que companhias e dirigentes que buscam ativa e sistematicamente tornar suas empresas responsáveis deveriam ser recompensados com menores penalidades, ao passo que maiores sanções sejam aplicadas em empresas sem políticas de compliance ${ }^{648}$.

Para a difícil tarefa de avaliar um programa interno de compliance, Parker ${ }^{649}$ explica que a empresa deve alinhá-lo ao sistema disciplinar interno, aos seus valores,

\footnotetext{
${ }^{642}$ ERHARD, Werner; JENSEN, Michael C.; ZAFFRON, Steve. Integrity: a positive model that incorporates the normative phenomena of morality, ethics and legality.p.105.

${ }^{643}$ SIEBER, Ulrich. ENGELHART, Marc. op.cit. p.02.

${ }^{644}$ SAAD-DINIZ, Eduardo. A criminalidade empresarial e a cultura de compliance. Revista Eletrônica de Direito Penal AIDP-GB, v. 2, 2014. p.112.

${ }^{645}$ SIEBER, Ulrich. Programas de compliance em direito penal empresarial: um novo conceito para o controle da criminalidade econômica. In: OLIVEIRA, William Terra de; LEITE, NETO, Pedro Ferreira; ESSADO, Tiago Cintra; SAAD-DINIZ, Eduardo (orgs.). Direito penal econômico: estudos em homenagem aos 75 anos do Professor Klaus Tiedemann. São Paulo: LiberArs, 2013. p.312.

${ }^{646}$ PARKER, Christine. op.cit. p.01-02.

${ }^{647}$ PARKER, Christine. op.cit. p.03.

${ }^{648}$ PARKER, Christine. op.cit. p.03.

${ }^{649}$ PARKER, Christine. op.cit. p.06-10.
} 
respeitando a integridade dos funcionários e permitindo à empresa identificar erros e maus comportamentos de forma preventiva; estabelecer um plano junto aos stakeholders para que estes possam contestar e participar da tomada de decisões; determinar estratégias para receber as reclamações dos stakeholders internos e externos; criar uma agenda de avaliação ao programa; garantir livre acesso aos funcionários e dirigentes às funções de compliance; avaliação da performance e dos processos de compliance (se o alcance e a estratégia continuam apropriadas para a organização, bem como uma verificação de relatórios).

Os reguladores precisam assegurar-se que não só desenvolveram um sistema de padrões apropriados, mas que o implementaram de uma forma que fará diferença de acordo com o contexto e características de seus negócios ${ }^{650}$. A medida mais realista para avaliar a implementação do sistema de compliance seria, portanto, uma auto avaliação da empresa a partir de critérios como revisões da efetividade das hotlines; o treinamento dos funcionários; teste de procedimentos; planos de administração e auditorias internas e garantias de qualidade ${ }^{651}$. É importante frisar que uma auditoria terá maior credibilidade e segurança caso seja feita por uma empresa completamente independente.

A terceira fase proposta pela autora, para a avaliação do desempenho do programa de compliance, envolveria identificar e corrigir brechas encontradas nos modelos de regulação da empresa; se os resultados esperados com o programa foram atingidos e se a companhia estaria utilizando sua própria monitoração para já melhorar suas práticas ${ }^{652}$. Uma empresa que busque cooperar com o governo precisará ver o ambiente de trabalho com os olhos de uma investigação criminal, considerando que, quando a empresa e seus funcionários tornam-se sujeitos e alvos de investigações do governo, os especialistas vão ver a empresa como uma provável cena de crime ${ }^{653}$.

Para isso, uma sistematização dos deveres e garantias das empresas, como o detalhamento dos possíveis déficits de organização, as consequências do não agir de acordo com o esperado ou eventuais falhas nos programas de compliance deve fazer parte

\footnotetext{
${ }^{650}$ PARKER, Christine. Is there a reliable way to evaluate organisational compliance programs? Disponível em: <http://www.aic.gov.au/media_library/conferences/regulation/parker.pdf $>$. Acesso em 15 de abril de 2015. p.08.

${ }^{651}$ PARKER, Christine. op.cit. p.09.

${ }^{652}$ Para cumprir tal etapa a empresa deveria buscar padrões apropriados para enfrentar riscos; garantir que o sistema de compliance esteja implementado em toda a organização e se, realmente, apresentou diferença no comportamento dos funcionários, na tomada de decisões e se o programa contribuiu para o alcance de valores sociais e resultados esperados. PARKER, Christine. op.cit. p.13.

${ }^{653}$ MARMER, Ronald L. WEISSMAN, Andrew. Think of the Corporate Office as a potential crime scene? p.02.
} 
de um sistema de aferição da culpabilidade corporativa ${ }^{654}$. Entretanto, ao determinar estas consequências pelo não-compliance, o regulador precisa tomar cuidado em não simplesmente colocar preços nas práticas ruins, mas regular de uma forma que produza o comprometimento das empresas com os bons programas de compliance, evitando assim o que Christine Parker chamou de deterrence trap, ou armadilha da dissuasão. Aqui, as penalidades pelo não-compliance serão ou graves demais para empresas menores, resultando em prejuízos para credores e funcionários inocentes, ou não serão suficientes para mudar o comportamento delituoso das grandes corporações ${ }^{655}$.

Para a autora, os reguladores devem misturar estilos de regulação que envolvam estratégias de melhoras dos programas de compliance juntamente com as práticas de dissuasão, especialmente as considerações do interesse público e o julgamento moral feito sobre as empresas condenadas ${ }^{656}$. As ações para aplicação da lei devem possibilitar oportunidades para que as empresas e seus dirigentes sejam convencidos da importância de suas atividades estarem de acordo com a lei e para os reguladores entenderem a complexidade das motivações que criam espaços para as violações, bem como usar tais falhas para melhorar a regulação. A execução das leis, seu enforcement, dependerá também de suporte político e democrático, para que as empresas não se vejam perseguidas por regulações que apenas buscam prejudicar seus negócios e estigmatizar suas atividades ${ }^{657}$.

Em muitas declarações sobre os valores e missões das empresas, aparecem afirmações sobre a importância da integridade em suas atividades. A partir do momento que algo básico com a integridade torna-se um diferencial, podemos mensurar a importância e a dificuldade em garantir sua existência ${ }^{658}$.

Ao Estado caberia estabelecer limites que impeçam que as empresas utilizem os programas de compliance de forma exclusiva a evitar sanções. Assim, Sieber e Engelhart

\footnotetext{
${ }^{654}$ SARCEDO, Leandro. Compliance e Responsabilidade Penal da Pessoa Jurídica: Construção de um novo modelo de imputação, baseado na culpabilidade corporativa. Faculdade de Direito, Universidade de São Paulo, São Paulo, 2014.p.265.

${ }^{655}$ PARKER, Christine. The compliance trap: the moral message in responsive regulatory enforcement. Disponível em <http:// http://papers.ssrn.com/sol3/papers.cfm?abstract_id=927559>. Acesso em 10 de dezembro de 2015.p. 03.

${ }^{656}$ PARKER, Christine. op.cit. p.04.

${ }^{657}$ PARKER, Christine. op.cit. p.29-34.

${ }^{658}$ Conforme afirma Ron Ashkenas, as boas práticas relacionadas com a integridade das empresas não podem ser baseadas apenas em regras, funções e medidas formais de compliance, mas sim em práticas cotidianas e seriam ressaltadas nas declarações empresariais como uma forma de ressaltar que a integridade não seria somente de responsabilidade empresarial, mas também individual. ASHKENAS, Ron. Why integrity is never easy. Harvard Business Review, 08 de fevereiro de 2011.
} 
afirmam a importância dos gatekeepers, dos sistemas de informações e de uma adequada recepção de tais denúncias dentro da empresa, bem como uma correta verificação de livros e documentos contábeis ${ }^{659}$. Em uma pesquisa realizada com empresas alemãs, foi constatado que a prevenção à corrupção é encontrada, nos programas de compliance, em 93\% das empresas que possuem tal regulamentação, seguido por questões relacionadas ao direito concorrencial e fraudes ${ }^{660}$. A pesquisa realizada por Sieber e Engelhart mostrou que, diante de incidentes, ainda que analisados pontualmente, as empresas tendem a corrigir as falhas encontradas ${ }^{661}$ e que a grande maioria delas $(88 \%)$ citou que os programas de compliance foram instituídos com a intenção de diminuir os riscos e $84 \%$ afirmou ter os programas por exigências legais ${ }^{662}$.

As pressões são reais e as métricas para avaliação dos programas de compliance corporativos estão distantes da perfeição, razão pela qual uma das soluções apresentadas seria o aumento da transparência organizacional e da participação de terceiros nas práticas preventivas $^{663}$. Para o bom desenvolvimento de um programa de compliance, todos os stakeholders deveriam participar de sua implementação, levantando questões que sejam importantes para cada parte de uma determinada empresa.

A busca única por lucros não é mais compatível com as atuais exigências normativas. A ideologia da primazia dos acionistas acima de todos os demais stakeholders mostra-se inadequada e oposta à boa governança das empresas. Além de prover sólidos retornos aos investidores cabem às empresas proporcionar um sustento decente aos seus funcionários, produzir bons produtos e serviços e contribuir com a comunidade ${ }^{664}$. Um objetivo focado apenas no valor das ações não servirá para os demais stakeholders. Esta questão torna-se mais delicada com os acionistas de curto prazo, preocupados unicamente com o valor das ações de uma determinada empresa e não com as suas atividades, valores e relatórios anteriores. Tais investidores não podem ser vistos como, apenas, inocentes vítimas nos casos de irregularidades financeiras. Ainda que muitos tenham sido enganados

\footnotetext{
${ }^{659}$ SIEBER, Ulrich. Programas de compliance em direito penal empresarial: um novo conceito para o controle da criminalidade econômica. In: OLIVEIRA, William Terra de; LEITE, NETO, Pedro Ferreira; ESSADO, Tiago Cintra; SAAD-DINIZ, Eduardo (orgs.). Direito penal econômico: estudos em homenagem aos 75 anos do Professor Klaus Tiedemann. São Paulo: LiberArs, 2013. p.313.

${ }^{660}$ SIEBER, Ulrich. ENGELHART, Marc. op.cit. p.40.

${ }^{661}$ SIEBER, Ulrich. ENGELHART, Marc. op.cit. p.81.

${ }^{662}$ SIEBER, Ulrich. ENGELHART, Marc. op.cit. p.117.

${ }^{663}$ LAUFER, William; GEIS, Gilbert. Corporate crime and a new brand of cooperative regulation. p.148.

${ }^{664}$ STOUT, Lynn. The Shareholder Value Myth: how putting shareholders first harms investors, corporations and the public. São Francisco, EUA: Berrett-Kochler Publishers, 2012. p.03.
} 
por análises tendenciosas e ganhos exagerados, suas responsabilidades não podem ser totalmente esquecidas $^{665}$.

A lógica dos "investidores inocentes", antes eufóricos com o mercado em alta, e agora profundamente abalados pelos delitos empresariais, deve ser analisada de forma cautelosa $^{666}$. Por exemplo, no caso Enron, $60 \%$ dos acionistas eram grandes investidores institucionais, por que nenhum conseguiu ver que as ações estavam sobrevalorizadas? Neste caso, Coffee Jr explica que o fato de um agente perceber uma anormalidade, não reconhecida pelo restante do mercado, pode tornar seu administrador um "profeta prematuro" e registrar desempenhos negativos ${ }^{667}$.

A necessidade de dados atualizados e transparentes favorece a todos, uma vez que uma prática forma de melhorar os valores das ações são as fraudes contábeis, como aconteceu nos casos da Enron e da WorldCom, reconhecendo-se que o mercado pode ser manipulado com valores que não necessariamente seguem a performance econômica das empresas $^{668}$. Portanto, investidores que não se envolvam com o cotidiano da empresa não estarão em posição de ter conhecimento de possíveis práticas corporativas irregulares ${ }^{669}$. Esta teoria da total atenção dada aos retornos dos acionistas mostra-se prejudicial às atividades da empresa e quando combinada com a estrutura do mercado financeiro, cria grandes obstáculos para o comportamento correto de investidores e gerentes ${ }^{670}$. Para Lynn Stout, deve-se parar de responder aos escândalos e crises financeiras com tentativas de melhoras à governança corporativa que façam os conselhos e dirigentes mais responsáveis sem que haja uma mudança na mentalidade do mercado e das empresas em relação à maior importância dos acionistas ${ }^{671}$.

Para Renato de Mello Jorge Silveira, a nova cultura de compliance teria como foco central a dificuldade de se determinar a responsabilidade de práticas delituosas realizadas

\footnotetext{
${ }^{665}$ COFFEE JR, John C. What caused Enron? 20 de janeiro de 2003. Columbia Law \& Economics Working Paper n. 214. p.37.

${ }^{666}$ SAAD-DINIZ, Eduardo. Escândalos de corrupção corporativa: filme de terror sem fim?. Boletim IBCCRIM, São Paulo, v. 23, n. 274, set. 2015. p.12.

${ }^{667}$ COFFEE JR, John C. What caused Enron? 20 de janeiro de 2003. Columbia Law \& Economics Working Paper n. 214. p.38.

${ }^{668}$ STOUT, Lynn. The Shareholder Value Myth: how putting shareholders first harms investors, corporations and the public. São Francisco, EUA: Berrett-Kochler Publishers, 2012. p.68-69.

${ }^{669}$ STOUT, Lynn. op.cit. p.99.

${ }^{670}$ STOUT, Lynn. op.cit. p. 101.

${ }^{671}$ STOUT, Lynn. op.cit. p.111.
} 
dentro de um específico âmbito empresarial ${ }^{672}$. Realidade esta já presente, por exemplo, no artigo 31 do Código Penal Espanhol, segundo o qual pessoas jurídicas poderiam ser responsabilizadas penalmente pelos delitos praticados em seu nome, em função delas ou em seu proveito, por seus representantes e administradores, de forma que a empresa não mais se porte como um instrumento delitivo ou uma organização criminal com status jurídico, mas como uma organização, ciente de sua complexidade, e que verdadeiramente se preocupe com uma efetiva aplicação de compliance ${ }^{673}$. Ressalta Adán Nieto Martín que “a relação entre os diversos setores de autorregulação empresarial e a prevenção dos feitos delitivos não somente é significativa para estabelecer a relação entre as normas (administrativas, de uniformização, de um lado, e penais, de outro), senão também para determinar a organização da empresa e atribuir responsabilidades ${ }^{674,}$.

Haveria, portanto, a obrigação das empresas em se comportarem como boas cidadãs corporativas, através de uma política de autorregulação regulada, que viria a servir, inclusive, para abrandar sua responsabilidade penal em caso de ocorrências criminosas ${ }^{675}$. Para Coca Vila, os programas de compliance seriam um elemento chave para fundamentar a responsabilidade empresarial, diante de sua não adoção ou adoção deficiente sendo o delito empresarial decorrente do fato da empresa não ter se autorregulado de maneira eficaz, evidenciando o déficit de cumprimento ao direito ${ }^{676}$. Críticas podem ser direcionadas ao fato de que estes programas criados para prevenir a prática delituosa e prejudicial aos interesses dos stakeholders, tornem-se "uma estrutura repressiva disponível aos órgãos responsáveis pela aplicação da lei penal ${ }^{677, "}$.

O compliance funciona bem se acompanhado de procedimentos internos, normas de controle e análises de risco que assegurem sua eficácia ${ }^{678}$. De grande importância, as auditorias desempenhavam, originalmente, um papel de detectar fraudes internas

\footnotetext{
${ }^{672}$ SILVEIRA, Renato de Mello Jorge; SAAD-DINIZ, Eduardo. Compliance, Direito Penal e Lei Anticorrupção. São Paulo: Saraiva, 2015. p.85.

${ }^{673}$ SILVEIRA, Renato de Mello Jorge; SAAD-DINIZ, Eduardo. op.cit. p.101-103.

${ }^{674}$ NIETO MARTÍN, Adán. Problemas fundamentales del cumplimiento normative en el derecho penal. In: KUHLEN, Lothar (ed.). MONTIEL, Juan Pablo (ed.). ORTIZ DE URBINA GIMENO, Iñigo (ed.). Compliance y teoria del derecho penal. Madrid: Marcial Pons, 2013. p.29.

${ }^{675}$ SILVEIRA, Renato de Mello Jorge; SAAD-DINIZ, Eduardo. op.cit. p.104.

${ }^{676}$ COCA VILA, Ivó. ¿Programas de cumplimiento como forma de autorregulación regulada? In: MONTANER FERNÁNDEZ, Raquel (coord.). Criminalidad de empresa y compliance. Prevención y reacciones corporativas. Barcelona: Atelier, 2013. p.64.

${ }^{677}$ SARCEDO, Leandro. Compliance e Responsabilidade Penal da Pessoa Jurídica: Construção de um novo modelo de imputação, baseado na culpabilidade corporativa. Faculdade de Direito, Universidade de São Paulo, São Paulo, 2014. p.45.

${ }^{678}$ NIETO MARTÍN, Adán. op.cit. p.25.
} 
cometidas por diretores e funcionários da empresa. Com o incremento de novos controles e exigências de maiores divulgações, torna-se necessário não só a transparência econômica, mostrada em números, mas também maior transparência organizativa, ética e social ${ }^{679}$.

Uma importante lição para as organizações corporativas é que quanto mais confiáveis forem os controles internos, menor será a necessidade de uma auditoria intrusiva externa ${ }^{680}$. Esta revisão constante interna a ser realizada dentro da empresa deve apresentar um caráter multidisciplinar, com a participação de auditores, profissionais de informática, administradores de empresa, especialistas de ética empresarial e, especialmente, a participação de um advogado penalista para orientar (fazer análise dos riscos jurídicos e barreiras de proteção), analisar ocasiões que gerem maior risco de delitos, e seu devido controle, desenhar um programa de compliance e as ferramentas de denúncias e investigações internas, levando em consideração que um programa mal desenhado pode ser um multiplicador de deveres de garantias, sendo importante determinar quais as medidas a serem tomadas diante das falhas encontradas ${ }^{681}$.

Em uma realidade de autorregulação, as empresas mostram-se como as maiores conhecedoras de suas próprias estruturas e riscos. A partir das exigências estatais de que se implementem programas de prevenção, a melhor forma de agir em conformidade com a lei será colocando os procedimentos éticos e preventivos em prática. Com ampla participação e contribuição de todos os stakeholders, o programa de compliance deve focar em treinamentos que desenvolvam e fortaleçam os corretos valores da empresa e, em caso de necessidade, disponibilizar sistemas de informação para receber as denúncias que possam surgir.

\footnotetext{
${ }^{679}$ NIETO MARTÍN, Adán. El programa político-criminal del corporate goverment: derecho penal de la empresa y gobierno corporativo. Revista Aranzadi de derecho y proceso penal, Navarra, n. 11, 2004. p.277. ${ }^{680}$ ROSEN, Robert Eli. Risk Management and Corporate Governance: The Case of Enron. 35 Connecticut Law Ver. 2003. p.1184.

${ }^{681}$ GONZÁLEZ FRANCO, José Ángel; SCHEMMEL Alexander; BLUMENBERG, Axel. La función del penalista en la confección, implementación y evaluación de los programas de cumplimiento. In: In: ARROYO ZAPATERO, Luis (dir.). NIETO MARTÍN, Adán (dir.). El derecho penal económico en la era compliance. Valência: Ed. Tirant lo Blanch, 2013.p.159-162. Renato de Mello Jorge Silveira também destaca o importante papel do advogado criminalista no desenvolvimento e implementação do programa de compliance, considerando a necessidade de elucidação e prevenção de condutas que possam resultar em práticas de corrupção. SILVEIRA, Renato de Mello Jorge. Ponderações sobre o compliance criminal. Valor Econômico, 01 de julho de 2014.
} 


\subsubsection{O compliance officer e o dever de vigilância}

Os programas de compliance demandam das empresas que implementem valores éticos dentro de suas atividades. Para que isso seja possível os valores desta empresa terão que fazer parte do cotidiano de todos os seus funcionários. Neste contexto, surge a figura de uma nova posição de dever dentro das organizações, que é a figura do compliance officer, cujas função vai envolver a gestão e a correção dos indícios que se mostrem defeituosos no decorrer das atividades da empresa ${ }^{682}$.

Constitui um dever da empresa o estabelecimento de uma estrutura organizacional que implemente o objetivo de agir de acordo com o Direito. Ao desenvolver tais estruturas, as empresas fazem com que seus administradores e funcionários assumam os valores éticos necessários e compartilhados com o Estado e, assim, cumpram a lei ${ }^{683}$. Entretanto, este novo dever exigido das empresas evidencia, para Christine Parker, problemas como a confiança exagerada na avaliação das empresas de seus riscos e a criação de um fardo que pode tornar-se intolerável para aqueles que farão parte desta nova equipe de prevenção ${ }^{684}$.

Ao repassar as funções de prevenção para as empresas e seus profissionais, é necessário que o Estado ofereça uma regulamentação específica sobre as obrigações que devem ser observadas, para que não haja uma grande "heterogeneidade no exercício dessa posição, com nomenclaturas e funções que variam bastante de empresa para empresa ${ }^{685 "}$.

Ainda que esta implementação possa apresentar algumas desvantagens iniciais como o engessamento da produção, a ampliação da responsabilização, o aumento dos custos internos e mesmo uma indefinição no momento da aplicação judicial, as vantagens mostram-se como incentivos para sua aplicação, como o controle da responsabilização de cada funcionário, com funções estabelecidas e identificadas, a vantagem competitiva, a atração de stakeholders (mão-de-obra qualificada, acionistas seguros da transparência e das

\footnotetext{
${ }^{682}$ SILVA SÁNCHEZ, Jesús-María. Deberes de vigilancia y compliance empresarial. In: KUHLEN, Lothar (ed.). MONTIEL, Juan Pablo (ed.). ORTIZ DE URBINA GIMENO, Iñigo (ed.). Compliance y teoria del derecho penal. Madrid: Marcial Pons, 2013.p.103.

${ }^{683}$ NIETO MARTÍN, Adán. Responsabilidad social, gobierno corporativo y autorregulación: sus influencias en el derecho penal de la empresa. Polít. crim., № 5, 2008, A3-5, p.06.

${ }^{684}$ PARKER, Christine. The open corporation: effective self-regulation and democracy. Nova York: Cambridge University Press, 2002. p.136.

${ }^{685}$ SARCEDO, Leandro. Compliance e Responsabilidade Penal da Pessoa Jurídica: Construção de um novo modelo de imputação, baseado na culpabilidade corporativa. Faculdade de Direito, Universidade de São Paulo, São Paulo, 2014.p.68.
} 
informações disponibilizadas), a melhoria do padrão de gestão e a manutenção de padrões internacionais $^{686}$.

A identificação dos riscos no âmbito empresarial não é um processo estático, mas vai depender de uma ininterrupta vigilância por parte dos supervisores que deverão assegurar uma gestão cujas informações circulem e sejam devidamente explicadas e conhecidas. E, neste sentido, os programas de cumprimento também devem ser acompanhados e atualizados, na medida em que apresentem falhas ou já não abarquem todos os riscos a que está exposta a organização ${ }^{687}$.

Além de apresentar plena autonomia em suas funções, o compliance officer deverá ter, ao mesmo tempo, total apoio e suporte dos recursos da empresa ${ }^{688}$. Deve-se considerar que ele poderá encontrar resistência dentro de alguns setores da empresa que enxerguem as suas atividades como perda de tempo ou dinheiro e, ainda que avisados, optem por exercer as antigas práticas em seus negócios. Conforme afirma Parker, conflitos entre os objetivos da área de compliance e as metas da empresa são prováveis de aparecer de forma regular, se não frequente ${ }^{689}$.

Os compliance officers serão responsáveis por incutir as boas práticas e os valores da empresa nas atividades cotidianas, sendo-lhes atribuído o o dever de supervisão da direção empresarial, cujo dever jurídico será alcançar um estado de conhecimento que lhe permita a concepção e a implementação de medidas de supervisão que reduzam e mantenham sob controle os riscos gerados a partir das atividades da empresa ${ }^{690}$. Para Dennis Bock, quanto maior a probabilidade de danos pela inobservância das regras devidas, maiores serão as medidas a serem adotadas. Assim, assume o compliance officer parte do dever de garantia e cuidado que originariamente seria do empresário, bem como o

\footnotetext{
${ }^{686}$ SAAD-DINIZ, Eduardo. A criminalidade empresarial e a cultura de compliance. Revista Eletrônica de Direito Penal AIDP-GB, v. 2, 2014.p.116.

${ }^{687}$ Christine Parker e Vibeke Nielsen, ao analisarem diversas empresas, afirmam que estudos demonstraram que melhores controles administrativos internos e cultura de compliance são os fatores que condicionam melhores performances de compliance. O importante mostra ser a forma como os procedimentos éticos e preventivos são colocados em prática, nas tomadas de decisões cotidianas, e não apenas a existência formal deles. PARKER, Christine; NIELSEN, Vibeke Lehmann. Corporate Compliance Systems: could they make any difference? Administration and Society n.41, December, 2008.

${ }^{688}$ MARTIN, Jay; McCONNELL, Ryan D.; SIMON, Charlotte A. Plan now or pay later: the role of compliance in criminal cases. Houston: Forthcoming UH International Law Journal, 2011.p.55.

${ }^{689}$ PARKER, Christine. The open corporation: effective self-regulation and democracy. Nova York: Cambridge University Press, 2002. p.145.

${ }^{690}$ BOCK, Dennis. Compliance y deberes de vigilancia en la empresa. In: KUHLEN, Lothar (ed.). MONTIEL, Juan Pablo (ed.). ORTIZ DE URBINA GIMENO, Iñigo (ed.). Compliance y teoria del derecho penal. Madrid: Marcial Pons, 2013. p.113.
} 
“dever de informação aos órgãos competentes pela área em que se encontra o problema detectado, assim como à administração superior da empresa a qual for subordinado ${ }^{691,}$.

Tendo em vista a impossibilidade do estabelecimento de controles e regras para cada eventualidade no ambiente empresarial ${ }^{692}$, a função dos compliance officers já terá início já na contratação dos funcionários, que deverão deverão ser selecionados de forma adequada e cuidadosa, Com isso, os responsáveis pelos programas de compliance poderão desenvolver um ambiente empresarial que dificulte a comissão de condutas delitivas em suas atividades, através de uma combinação de esforços que envolvem diferentes direções, por exemplo: a orientação, divulgação, reforço das normas internas, através dos códigos de ética e de boa governança, a formação dos funcionários, investigações efetivas diante de indícios de atividades delituosas, auditorias, canais de denúncia, etc. ${ }^{693}$.

Estes profissionais, portanto, assumem uma dupla função de assegurar que a empresa aja de acordo com a lei e que estes valores sejam internalizados pelos funcionários ${ }^{694}$. Esta difícil tarefa torna-se ainda mais complexa quando consideramos que uma empresa é formada por diferentes stakeholders que terão suas prioridades e serão atingidos de formas distintas com as práticas de prevenção.

Uma das maiores preocupações encontradas pelos compliance officers está relacionada com a prevenção a fraudes e outros crimes que ocorram dentro da empresa. No atual momento do direito penal caracterizado pela prevenção, alguns breves apontamentos devem ser feitos à responsabilização criminal que se expande às figuras destes funcionários. Afirma Dopico Gómez-Aller que, em linhas gerais, "a maioria das tarefas implicadas à posição de garante do empresário são deveres de controle de um foco de perigo", constituindo, assim, a negligência e o não cumprimento das normas por parte dos executores um foco de perigo que deve ser assegurado ${ }^{695}$. Cumpre ressaltar que, para o

\footnotetext{
${ }^{691}$ SARCEDO, Leandro. Compliance e Responsabilidade Penal da Pessoa Jurídica: Construção de um novo modelo de imputação, baseado na culpabilidade corporativa. Faculdade de Direito, Universidade de São Paulo, São Paulo, 2014.p.71.

${ }^{692}$ BOCK, Dennis. Compliance $y$ deberes de vigilancia en la empresa. In: KUHLEN, Lothar (ed.). MONTIEL, Juan Pablo (ed.). ORTIZ DE URBINA GIMENO, Iñigo (ed.). Compliance y teoria del derecho penal. Madrid: Marcial Pons, 2013. p.116-118.

${ }^{693}$ DOPICO GÓMEZ-ALLER, Jacobo. Posición de garante del compliance officer por infracción del "deber de control”: una aproximación tópica. In: ARROYO ZAPATERO, Luis (dir.). NIETO MARTÍN, Adán (dir.). El derecho penal económico en la era compliance. Valência: Ed. Tirant lo Blanch, 2013.p.166.

${ }^{694}$ PARKER, Christine. The open corporation: effective self-regulation and democracy. Nova York: Cambridge University Press, 2002. p.155.

${ }^{695}$ DOPICO GÓMEZ-ALLER, Jacobo. op.cit. p.170. No mesmo sentido, Imme Roxin explica que "é dever do administrador manter a fonte de perigo sob controle e também cuidar do desenrolar regular e ordenado de
} 
autor, o compliance officer pode ser encarregado da prevenção de delitos como fraudes e a prática de corrupção, porém não de outros mais relacionados com os riscos operativos, como os delitos ambientais, contra a segurança de trabalho, cujos controles estão designados a departamentos técnicos especializados ${ }^{696}$.

No Código Penal espanhol, a infração de dever de controle sobre as pessoas subordinadas a administradores e representantes das empresas, a quem são atribuídas as funções de supervisão, vigilância e controle está prevista no art. $31^{697}$. Explica Ricardo Robles Planas que nem todos os riscos da atividade empresarial podem ser imputados ao encarregado pelo programa de compliance, que ocupa uma posição independente, porém subordinada aos órgãos de direção, sendo responsável pelas funções de implementação e formação do programa e obtenção de informações ${ }^{698}$.

Kai Ambos explica que a jurisprudência moderna teria estabelecido três requisitos para apreciar a responsabilidade do superior dentro de uma organização: a) a existência de uma relação superior-subordinado; b) a omissão do superior em tomar as medidas necessárias e razoáveis para impedir os crimes de seus subordinados e castiga-los caso tenham cometido alguma infração e c) o conhecimento do superior ou que este tivesse razoes para saber que crimes estavam para acontecer $^{699}$. Dopico Gómez-Aller entende ainda possível haver a responsabilização caso o delito praticado pelo subordinado tivesse a prevenção como uma das competências do garantidor, o que deverá ser examinado em cada caso concreto, uma vez que as diferentes atividades trazem riscos diversos às empresas $^{700}$.

Para Ambos, a ignorância da comissão de um determinado crime por um dos seus subordinados, não poderia ser utilizada contra o supervisor se este cumpriu, adequadamente, com seus deveres de supervisão e esteve atento às informações que

sua empresa para que esta e sua atividade empresarial não acarretem danos jurídico-penais relevantes a terceiros”. ROXIN, Imme; LEITE, Alaor; TEIXEIRA, Adriano (Trad.). Responsabilidade do administrador de empresa por omissão imprópria. Revista Brasileira de Ciências Criminais, São Paulo, v. 23, n. 112, p.6177, jan./fev. 2015.p.68.

${ }^{696}$ DOPICO GÓMEZ-ALLER, Jacobo. Posición de garante del compliance officer por infracción del "deber de control": una aproximación tópica. op.cit.p.182-183.

${ }^{697}$ ROBLES PLANAS, Ricardo. El responsable de cumplimiento (“compliance officer”) ante el derecho penal. In: SILVA SÁNCHEZ, Jesús-María (dir.). MONTANER FERNÁNDEZ, Raquel (coord.). Criminalidad de empresa y compliance. Barcelona: Atelier Libros, 2013. p.320.

${ }^{698}$ ROBLES PLANAS, Ricardo. op.cit. p.321.

${ }^{699}$ AMBOS, Kai. "Joint criminal enterprise" y la responsabilidad del superior. Revista de Derecho Penal y Criminología: Espanha, Madrid, 2a Época, n. 19, jan. 2007. p.44.

${ }^{700}$ DOPICO GÓMEZ-ALLER, Jacobo. Presupuestos básicos de la respnsabilidad penal del Compliance Officer y otros garantes en la empresa. Actualidad jurídica Aranzadi, № 843, 2012, pág. 6. 
poderiam indicar o delito ${ }^{701}$. O cumprimento de dever de garante será produzido, como explica Robles Planas, "mediante a adoção de mecanismos de vigilância sobre os cursos ou processos próprios da atividade empresarial que possam gerar perigos a terceiros, incluindo aqueles provocados por seus subordinados ${ }^{702}$,

Desloca-se, conforme critica Prittwitz, os riscos de responsabilidade e punibilidade a indivíduos que "são servidos em bandejas de prata à persecução penal", responsáveis pelas funções não só de organizar e administrar os programas de compliance, mas também de serem identificados pelo não cumprimento das exigências legais ${ }^{703}$.

Para Helena Regina Lobo da Costa e Marina Pinhão Coelho Araújo, o compliance officer poderia ser não apenas um único indivíduo, mas um setor interno da empresa ou mesmo externo, como auditores e auditores. Entendem que as noções de compliance e de direito penal devem ser tratadas com muita cautela, uma vez que o primeiro estaria voltado às práticas de prevenção e o segundo com a reação ao ilícito ${ }^{704}$. Aplicar o direito penal dentro das atividades de compliance exigirá uma análise contextualizada do compliance officer, suas funções exercidas e o grau de autonomia e poder que the foi conferido pela empresa. Ao verificarmos na prática, os compliance officers raramente serão responsáveis pela tomada de decisões dentro da empresa, estas estarão vinculadas aos administradores executivos.

Com a responsabilidade de emitir alertas sobre riscos que podem resultar de determinadas decisões, a área de compliance vai funcionar como uma linha auxiliar da administração $^{705}$. Neste sentido, as autoras trazem a discussão sobre a responsabilização destes funcionários em caso de fraudes ou ilícitos que sejam cometidos no âmbito empresarial. Até que ponto haveria o dever de garantidor do compliance officer? Conforme explicam o compliance officer "não assume o dever de evitar todo e qualquer resultado de

\footnotetext{
${ }^{701}$ AMBOS, Kai. op.cit. p.45.

${ }^{702}$ ROBLES PLANAS, Ricardo. El responsable de cumplimiento (“compliance officer") ante el derecho penal. In: SILVA SÁNCHEZ, Jesús-María (dir.). MONTANER FERNÁNDEZ, Raquel (coord.). Criminalidad de empresa y compliance. Barcelona: Atelier Libros, 2013. p.323.

${ }^{703}$ PRITTWITZ, Cornelius. La posición jurídica (en especial, posición de garante) de los compliance officers. In: KUHLEN, Lothar (ed.). MONTIEL, Juan Pablo (ed.). ORTIZ DE URBINA GIMENO, Iñigo (ed.). Compliance y teoria del derecho penal. Madrid: Marcial Pons, 2013. p.217.

${ }^{704}$ COSTA, Helena Regina Lobo da; ARAÚJO, Marina Pinhão Coelho. Compliance e o julgamento da APn 470. Revista Brasileira de Ciências Criminais, São Paulo, v. 22, n. 106, jan./fev. 2014. p.229.

${ }^{705}$ COSTA, Helena Regina Lobo da; ARAÚJO, Marina Pinhão Coelho. op.cit. p.223.
} 
prática de crimes dentro da empresa, mas sim de estabelecer regras, fiscalizar e comunicar problemas aqueles que detêm, na empresa, os poderes de administração ${ }^{706, "}$.

Não se espera do compliance officer personalidades mais éticas ou virtuosas do que os demais funcionários da empresa ${ }^{707}$. Sua função não seria executiva, mas caberia a ele transmitir as informações obtidas pelo dever de vigilância sobre o correto cumprimento do Direito aos superiores competentes. Neste mesmo sentido, explica Renato Silveira que a posição de compliance officer, ainda que delegada, assume uma posição de garante que será responsável somente pelo alerta sobre os riscos evidentes e inerentes às decisões tomadas pelos órgãos de direção ${ }^{708}$.

Inclusive sobre as tomadas de decisões, extremamente importantes para o desenvolvimento de uma boa governança nas empresas, Silva Sánchez ${ }^{709}$ explica que muitos são os fatores psicológicos que podem influenciar, positiva ou negativamente, as decisões no âmbito empresarial. Fatores como excesso de confiança, otimismo, ilusão de controle ou egoísmo influenciam as decisões dos agentes e geram riscos derivados da má avaliação realizada, por exemplo. Também podem ser prejudiciais à governança corporativa os vícios de decisões conjuntas, como as decisões direcionadas pela maioria dos Conselhos de Administração ou a obediência a uma ordem do superior que se saiba ilícita, de forma que seria razoável que os programas de compliance contivessem um sistema de controle constante sobre a tendência a esses sesgos cognitivos.

O problema é que as fraudes e ações corruptas, por exemplo, não são facilmente perceptíveis pelos administradores da empresa e a detectabilidade dos delitos dos subordinados é um pressuposto para que seja possível a punibilidade do administrador da empresa $^{710}$. A antecipação de uma possível responsabilização penal da empresa e os comportamentos futuros de seus funcionários apresentam-se como desafios à área de

\footnotetext{
${ }^{706}$ COSTA, Helena Regina Lobo da; ARAÚJO, Marina Pinhão Coelho. op.cit. p.226.

${ }^{707}$ PARKER, Christine. The open corporation: effective self-regulation and democracy. Nova York: Cambridge University Press, 2002. p.170.

${ }^{708}$ SILVEIRA, Renato de Mello Jorge; SAAD-DINIZ, Eduardo. Compliance, Direito Penal e Lei Anticorrupção. São Paulo: Saraiva, 2015. p.144.

${ }^{709}$ SILVA SÀNCHEZ, Jesús-María. Responsabilidades individuales em estructuras de empresa: la influencia de sesgos cognitivos y dinâmicas de grupo. In: SILVA SÁNCHEZ, Jesús-María (dir.). MONTANER FERNÁNDEZ, Raquel (coord.). Criminalidad de empresa y compliance. Barcelona: Atelier Libros, 2013. p. 268 e ss.

${ }^{710}$ ROXIN, Imme; LEITE, Alaor; TEIXEIRA, Adriano (Trad.). Responsabilidade do administrador de empresa por omissão imprópria. Revista Brasileira de Ciências Criminais, São Paulo, v. 23, n. 112, p.61-77, jan./fev. 2015.p. 73.
} 
compliance das empresas, razões pelas quais o programa deve levar em consideração todos os trabalhadores e não só a cúpula diretiva ${ }^{711}$.

Inúmeras dificuldades apresentam-se na realidade do compliance officer. Integrar valores éticos às atividades negociais, implementar procedimentos que internalizem estes valores nos funcionários, de todos os escalões, comunicando aos responsáveis as falhas que aconteçam ou a ocorrência de condutas irregulares. Será dever do responsável pelo compliance iniciar investigações diante de indícios de condutas irregulares, buscando interromper as que possam ser prejudiciais à empresa e/ou a terceiros, caso contrário poderá ser responsabilizado por omissão pelo não impedimento de condutas delituosas e sua posição de garante perante a empresa. Silva Sánchez traz que os superiores hierárquicos ocupam uma posição de garantia sobre as condutas realizadas por seus subordinados, o que poderia ainda ser justificado pelo dever de garantir o bem jurídico protegido e violado. Assim, os administradores teriam o duplo dever de proteger e salvaguardar determinados bens jurídicos e o dever de vigilância ao serem responsáveis por determinadas fontes de perigos ${ }^{712}$.

As investigações internas são consideradas de grande importância para o Estado e para a empresa, pois não só ajudam a esclarecer condutas empresariais suspeitas, permitindo a identificação de responsáveis dentro da empresa, como permitem a colaboração com os órgãos judiciais ${ }^{713}$. Diante da complexidade das estruturas empresariais, é imprescindível que este controle interno seja parte de um sólido programa de compliance capaz de prevenir a criminalidade econômica e permitir que as informações cheguem aos departamentos responsáveis. Funcionam como parte do controle exercido pela empresa em relação aos meios produtivos colocados à disposição dos trabalhadores, nos exercícios de suas funções ${ }^{714}$, investigando comportamentos irregulares de funcionários e administradores. Por esta razão, críticos afirmam que tais práticas seriam uma privatização das investigações que seriam de responsabilidade do Estado, colocando

\footnotetext{
${ }^{711}$ ROTSCH, Thomas. Criminal compliance. InDret Revista para el análisis del derecho. Barcelona, jan., 2012.p. 07-09.

${ }^{712}$ ROXIN, Imme; LEITE, Alaor; TEIXEIRA, Adriano (Trad.). op.cit. p. 62-63.

${ }^{713}$ MONTIEL, Juan Pablo. Autolimpeza empresarial: compliance programs, investigaciones internas y neutralización de riesgos penales. In: KUHLEN, Lothar (ed.). MONTIEL, Juan Pablo (ed.). ORTIZ DE URBINA GIMENO, Iñigo (ed.). Compliance y teoria del derecho penal. Madrid: Marcial Pons, 2013. p.221.

${ }^{714}$ GÓMEZ MARTİN, Victor. Compliance y derechos de los trabajadores. In: KUHLEN, Lothar (ed.). MONTIEL, Juan Pablo (ed.). ORTIZ DE URBINA GIMENO, Iñigo (ed.). Compliance y teoria del derecho penal. Madrid: Marcial Pons, 2013.p. 140.
} 
em risco garantias fundamentais e dando maior importância às práticas de compliance que ao próprio Direito ${ }^{715}$.

Juan Pablo Montiel critica a falta de mecanismos e regras prévios que regulamentem as investigações internas, como pessoas e órgãos responsáveis, os tipos de provas admissíveis, a estrutura dos interrogatórios e o uso a ser feito das informações obtidas $^{716}$. Até que ponto a empresa é obrigada a apresentar documentos que possam incrimina-la e ainda ter que arcar com todos os custos, tanto do controle prévio como das investigações ${ }^{717}$ ? Em grandes investigações pode ser necessária, inclusive, a participação de agentes externos à empresa, o que pode desencadear uma tensão entre as informações que podem ser analisadas e o imperativo da transparência. Klaus Moosmayer explica ainda que, muitas vezes, os processos de investigação, mesmo que possuam regulamentação nos Códigos de Conduta empresariais, podem apresentar problemas como a não cooperação de funcionários, o oferecimento de anistias internas e a necessidade de que aquele que realize os interrogatórios tenha experiência na atividade ${ }^{718}$.

É importante que os trabalhadores participem ativamente do desenho do programa e que as práticas implementadas nas investigações estejam de acordo com os princípios do Estado de Direito ${ }^{719}$. Montiel pondera, entretanto, que ações desautorizadas podem acabar por revelar informações privadas e violar, assim, a intimidade dos funcionários, razão pela qual o diretor responsável deverá comunicar aos trabalhadores caso haja modificação dos padrões estabelecidos ${ }^{720}$.

Ainda que as investigações internas sejam uma importante reação empresarial diante do cometimento de um delito, deve-se manter ressaltada a posição hierárquica superior que os cargos executivos possuem, de forma que não qualquer lesão à intimidade seja justificada, somente aquelas proporcionais e menos lesivas possível ${ }^{721}$. A intensidade da investigação dependerá do caso concreto, porém, desde o início, deverá estar claro se

\footnotetext{
${ }^{715}$ MOOSMAYER, Klaus. Investigaciones internas: una introducción a sus problemas esenciales. In: ARROYO ZAPATERO, Luis; NIETO MARTÍN, Adán (org) El derecho penal económico en la era compliance. Valencia: Tirant lo Blanch, 2013. p.137.

${ }^{716}$ MONTIEL, Juan Pablo. Autolimpeza empresarial: compliance programs, investigaciones internas y neutralización de riesgos penales. op.cit. p.225.

${ }^{717}$ NIETO MARTÍN, Adán. Regulatory Capitalism y cumplimiento normativo. In: ARROYO ZAPATERO, Luis; NIETO MARTÍN, Adán (coord). El derecho penal en la era compliance. Valencia: Tirant lo Blanch, 2013. p.19-23.

${ }^{718}$ MOOSMAYER, Klaus. op.cit. p.143.

${ }^{719}$ MONTIEL, Juan Pablo. op.cit. p.226.

${ }^{720}$ MONTIEL, Juan Pablo. op.cit. p.231-234.

${ }^{721}$ MONTIEL, Juan Pablo. op.cit. p.238-240.
} 
existe o dever legal de tornar público o resultado das investigações ${ }^{722}$. Neste sentido, é preciso que a empresa respeite a importância dos direitos individuais dos trabalhadores e a proteção de dados, o que será possível com uma regulação interna adequada de política disciplinaria $^{723}$.

Uma estrutura organizacional demandará da organização avaliações e monitoramentos constantes, função que poderá caber a um compliance officer. Algumas precauções devem ser consideradas, especialmente pela falta de regulamentação e pela complexidade de suas funções. O compliance officer deve fiscalizar as atividades de prevenção implementadas pela empresa e reportar irregularidades aos superiores responsáveis, necessitando para isso de amplo suporte e apoio da empresa.

\subsubsection{Whistleblower e canais de denúncia}

Considerando o desenvolvimento de um bom governo corporativo, cabe às empresas garantir um eficiente controle interno de fontes de riscos. Desta forma, as investigações internas são aperfeiçoadas com a existência de sistemas de denúncias de comportamentos e fatos que possam constituir violações de leis ou normas determinadas ${ }^{724}$. Estas práticas são parte de uma política de "portas abertas" que demonstram o interessa da empresa em praticar os princípios necessários para uma boa governança e boas práticas de compliance.

A expressão whistleblowing é utilizada para designar aqueles funcionários que denunciam fatos ilícitos ou pouco éticos, de uma determinada organização pública ou privada, realizados no âmbito empresarial pela empresa ou seus superiores ou terceiros ${ }^{725}$. Uma característica importante dos denunciantes é que eles não desempenhem dentro da organização funções controle ou investigação dos fatos denunciados.

\footnotetext{
${ }^{722}$ MOOSMAYER, Klaus. Investigaciones internas: una introducción a sus problemas esenciales. In: ARROYO ZAPATERO, Luis; NIETO MARTÍN, Adán (org) El derecho penal económico en la era compliance. Valencia: Tirant lo Blanch, 2013. p.139.

${ }^{723}$ MOOSMAYER, Klaus. op.cit. p. 140 .

${ }^{724}$ GÓMEZ MARTİN, Victor. Compliance y derechos de los trabajadores. In: KUHLEN, Lothar (ed.). MONTIEL, Juan Pablo (ed.). ORTIZ DE URBINA GIMENO, Iñigo (ed.). Compliance y teoria del derecho penal. Madrid: Marcial Pons, 2013.p. 129-130.

${ }^{725}$ RAGUÉS I VALLĖS, Ramon. Whistleblowing: una aproximación desde del derecho penal. Madrid: Marcial Pons, 2013. p.20.
} 
Trata-se de um mecanismo para a "prevenção e descobrimento de comportamentos delitivos, especialmente aos relacionados com a atividade empresarial e a corrupção da administração pública ${ }^{726 \%}$. Entretanto, é um instrumento que gera diferentes sentimentos, representando desde a figura de um traidor cujos objetivos podem não ser nobres, como no caso norte-americano em que o whistleblower recebe uma compensação financeira pelo "soprar do apito"; por outro lado, ao colocar em risco suas carreiras e interesses pessoais, podem ser considerados heróis e altruístas.

Todos os funcionários devem ser previamente informados da existência e das finalidades do programa de whistleblowing dentro da empresa, especialmente aqueles que estejam vinculados aos fatos denunciados ${ }^{727}$. Estes poderão solicitar a presença de um membro de confiança da empresa, como um advogado, quando for passar por um interrogatório $^{728}$. Estas garantias não podem ser relativizadas, uma vez que não é o objetivo dos canais de denúncia transformar o ambiente de trabalho em uma constante vigilância, em que os funcionários passam a desconfiar uns dos outros.

O processo a ser percorrido pelo whistleblower envolve a identificação a ação e determinar se ela é ilegal, imoral ou ilegítima e avaliar se a irregularidade deve ser reportada para a organização, que deverá realizar as investigações necessárias e ponderar qual a resposta a ser dada para a denúncia ${ }^{729}$. A investigação da denúncia deverá passar por uma avaliação de veracidade feita por um ombudsman ${ }^{730}$ e deverá contar com os mesmos direitos e garantias daquelas realizadas pelos órgãos estatais nos processos penais, para que assim a empresa não se torne um meio de elisão das garantias processuais ${ }^{731}$.

Conforme afirma Ramon Ragués I Vallès, particulares passam a assumir tarefas praticamente policiais, criando o perigo de que esta habilitação em nada contribua para o

\footnotetext{
${ }^{726}$ RAGUÉS I VALLÈS, Ramon. op.cit. p.21.

${ }^{727}$ GÓMEZ MARTİN, Victor. Compliance y derechos de los trabajadores. In: KUHLEN, Lothar (ed.). MONTIEL, Juan Pablo (ed.). ORTIZ DE URBINA GIMENO, Iñigo (ed.). Compliance y teoria del derecho penal. Madrid: Marcial Pons, 2013.p. 141.

${ }^{728}$ MASCHMANN, Frank. Compliance y derechos del trabajador. In: KUHLEN, Lothar (ed.). MONTIEL, Juan Pablo (ed.). ORTIZ DE URBINA GIMENO, Iñigo (ed.). Compliance y teoria del derecho penal. Madrid: Marcial Pons, 2013.p. 160.

${ }^{729}$ SAMPAIO, Diego Barreiros Dutra. Speak now or forever hold your peace: an empirical investigation of whistleblowing in Brazilian organizations. São Paulo: Escola Brasileira de Administração Pública e de Empresas, Centro de Formação Acadêmica e Pesquisa, 2012.p.12.

${ }^{730}$ MASCHMANN, Frank. op.cit. p.163.

${ }^{731}$ NIETO MARTÍN, Adán. Regulatory Capitalism y cumplimiento normativo. In: ARROYO ZAPATERO, Luis; NIETO MARTÍN, Adán (coord). El derecho penal en la era compliance. Valencia: Tirant lo Blanch, 2013. p.26.
} 
interesse público ${ }^{732}$. Diante do utilitarismo envolvido e da falta de ética de algumas denúncias, não pode o legislador impor aos cidadãos a prática da denúncia indefinidamente. Caberia a obrigatoriedade apenas para os casos mais graves, com notável interesse social, ou em situações em que a persecução penal mostre-se muito complicada ${ }^{733}$ e a identidade do denunciante deverá permanecer desconhecida para o denunciado e para o empresário $^{734}$.

Como grande parte das novas exigências no campo da governança corporativa e do compliance, a influência norte-americana ainda traz dúvidas em relação à aplicabilidade dos institutos no Brasil. Nossa cultura empresarial é baseada nos valores coletivos, na lealdade com o colega e na evitação de problemas ${ }^{735}$. O medo da retaliação também faz com que os funcionários de uma empresa sintam-se mais seguros em reportar irregularidades para canais externos de denúncias ${ }^{736}$, especialmente se o infrator exercer uma função superior na empresa ${ }^{737}$.

Desta forma, será função das empresas implementar hotlines que recebam as denúncias e as encaminhem para os responsáveis, sem transformar o ambiente de trabalho em um local influenciado pela desconfiança.

\subsubsection{Responsabilidade penal empresarial pelo déficit de organização}

Os padrões de condutas exigidos das empresas fazem com que estas busquem cumprir os mais diversos objetivos, como a prevenção dos riscos ambientais, trabalhistas, a segurança das informações e critérios de responsabilidade social corporativa e, neste contexto, aparece a responsabilidade penal das pessoas jurídicas como uma mensagem para que as empresas organizem-se de forma correta internamente, previnam e detectem fatos

\footnotetext{
${ }^{732}$ RAGUÉS I VALLÈS, Ramon. Whistleblowing: una aproximación desde del derecho penal. Madrid: Marcial Pons, 2013.p.39.

${ }^{733}$ RAGUÉS I VALLĖS, Ramon. op.cit. p.53.

${ }^{734}$ GÓMEZ MARTİN, Victor. Compliance y derechos de los trabajadores. In: KUHLEN, Lothar (ed.). MONTIEL, Juan Pablo (ed.). ORTIZ DE URBINA GIMENO, Iñigo (ed.). Compliance y teoria del derecho penal. Madrid: Marcial Pons, 2013.p.143.

${ }^{735}$ SAMPAIO, Diego Barreiros Dutra. Speak now or forever hold your peace: an empirical investigation of whistleblowing in Brazilian organizations. São Paulo: Escola Brasileira de Administração Pública e de Empresas, Centro de Formação Acadêmica e Pesquisa, 2012.p.17.

${ }^{736}$ Os canais externos de denúncias são criticados por exporem a organização aos efeitos negativos resultantes da publicidade adversa, perdas financeiras ou processos judiciais. SAMPAIO, Diego Barreiros Dutra. op.cit. p.29.

${ }^{737}$ SAMPAIO, Diego Barreiros Dutra. op.cit. p.19.
} 
delitivos que podem resultar em sanções graves ${ }^{738}$. Seguindo a lógica de John Coffee de

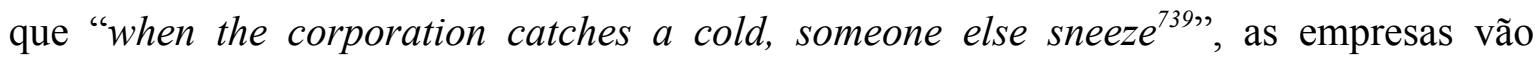
precisar organizar-se para que suas atividades sejam conduzidas de acordo com a norma.

As pessoas jurídicas são entes coletivos, nos quais existem pessoas organizadas de um modo específico e complexo e hierarquizadas sobre um poder de direção ${ }^{740}$. Conforme explica Leandro Sarcedo, há "um agir coletivo definido pela complexidade de todas as relações e condutas das pessoas que interagem pela consecução dos objetivos sociais das

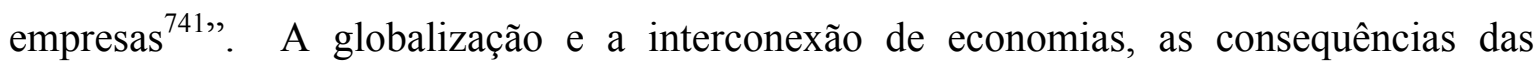
tecnologias modernas e as ameaças sobre o meio ambiente, fortaleceram a visão de que não só atores individuais, mas também corporações precisariam enfrentar a responsabilidade criminal pelos danos causados aos bens jurídicos internacionalmente reconhecidos $^{742}$.

As empresas progrediram muito com o passar dos tempos, principalmente na visão de que são instituições econômicas que devem respeitar os valores sociais, assim como buscar lucros com suas atividades ${ }^{743}$. Desta forma, é necessário que um sistema que demande responsabilidade pelo controle das atividades econômicas seja cumprido pela comunidade como um todo ${ }^{744}$. Para Laufer, "as empresas que expressam responsabilidade e integridade de forma autêntica são as que melhor servem a todo o setor privado de stakeholders de maneira sustentável ${ }^{745, "}$. Assim, as corporações poderiam ser identificadas com testes objetivos que mostrariam, de acordo com o tamanho, complexidade,

\footnotetext{
${ }^{738}$ NIETO MARTÍN, Adán. Problemas fundamentales del cumplimiento normativo en el derecho penal. In: KUHLEN, Lothar (ed.). MONTIEL, Juan Pablo (ed.). ORTIZ DE URBINA GIMENO, Iñigo (ed.). Compliance y teoria del derecho penal. Madrid: Marcial Pons, 2013. p.26;

${ }^{739}$ COFFEE JR, John C. No soul to damn: No body to kick: na unscandalized inquiry into the problem of corporate punishment. Michigan Law Review. Vol. 79, No. 3 (Jan. 1981), p. 401. Tradução: "Quando uma corporação pega um resfriado, outra pessoa espirra".

${ }^{740}$ LASCURAIIN, Juan Antonio. Compliance, debido control y unos refrescos. In: ARROYO ZAPATERO, Luis (dir.). NIETO MARTÍN, Adán (dir.). El derecho penal económico en la era compliance. Valência: Ed. Tirant lo Blanch, 2013.p.127.

${ }^{741}$ SARCEDO, Leandro. Compliance e Responsabilidade Penal da Pessoa Jurídica: Construção de um novo modelo de imputação, baseado na culpabilidade corporativa. Faculdade de Direito, Universidade de São Paulo, São Paulo, 2014.p.126.

${ }^{742}$ TIEDEMANN, Klaus. Corporate Criminal Liability as a Third Track. In: BRODOWSKI, Dominik; ESPINOZA DE LOS MONTEROS DE LA PARRA, Manuel; TIEDEMANN, Klaus (ed.). Regulating corporate criminal liability. Heidelberg: Springer, 2014. p. 11.

${ }^{743}$ DODD JR, Edwin Merrick. For whom corporate managers are trustees. 45, Harvard Law Review, 1932. p.1365.

${ }^{744}$ DODD JR, Edwin Merrick. op.cit. p.1368.

${ }^{745}$ LAUFER, William S. O compliance game. In: SAAD-DINIZ, Eduardo (org.); BRODOWSKI, Dominik (org.); SÁ, Ana Luiza de (org.). Regulação do abuso no âmbito corporativo: o papel do direito penal na crise financeira. São Paulo: Editora LiberArs, 2015.p.66.
} 
formalidade, funcionalidade, processos de tomada de decisões e estrutura da organização $^{746}$, se efetivamente possuíam um modelo de prevenção.

A responsabilização penal das pessoas jurídicas seria entendida, então, como uma reação à crescente importância das corporações, especialmente no âmbito econômico. No mundo globalizado, as empresas cada vez maiores, operam em escala mundial e utilizamse de regulamentações diferentes não apenas para pagar menos impostos, mas também para cometer irregularidades em detrimento do interesse público ${ }^{747}$ e superando, muitas vezes, os interesses e as fronteiras dos próprios Estados ${ }^{748}$. Em complexas estruturas empresariais em que as lesões e perigos são "resultados da conjunção de condutas em uma estrutura organizada", as informações encontram-se descentralizadas, facilitando a atividade criminosa $^{749}$. Conforme estudado previamente, o controle de todas as áreas da empresa, bem como os regulamentos de todos os locais em que ela tenha filiais, torna-se essencial para o bom desenvolvimento de suas atividades.

O protagonismo econômico das empresas somado aos fatores sociais e humanos aumentam o alcance dos escândalos corporativos como os ocorridos na Enron e na WorldCom, nos Estados Unidos, que serviram como catalizadores para estabelecer e reformar a responsabilidade penal das pessoas jurídicas ${ }^{750}$. Cumpre ressaltar nesta questão a ineficiência do Estado em conseguir regulamentar ou mesmo acompanhar as modificações tecnológicas, o que resultou na retomada da responsabilidade penal das empresas como política criminal a partir do momento em que passa a "conceder efeitos jurídicos às soluções dadas pelas empresas ao definir sua organização ${ }^{751 \text { ", }}$

O reconhecimento da responsabilidade criminal das empresas, portanto, "seria o resultado de uma política criminal de reconhecimento do papel relevante dos entes coletivos nas novas modalidades de criminalidade ${ }^{752}$ ". Explica Silva Sánchez, que a

\footnotetext{
${ }^{746}$ LAUFER, William S. op.cit. p.72.

${ }^{747}$ BRODOWSKI, Dominik; ESPINOZA DE LOS MONTEROS DE LA PARRA, Manuel; TIEDEMANN, Klaus. Regulating Corporate Criminal Liability: an introduction. In: BRODOWSKI, Dominik; DE LA PARRA, Manuel Espinoza de los Monteros; TIEDEMANN, Klaus (ed.). Regulating corporate criminal liability. Heidelberg: Springer, 2014. p.02.

${ }^{748}$ SHECAIRA, Sérgio Salomão. Responsabilidade Penal da Pessoa Jurídica. 3.ed. Rio de Janeiro: Elsevier, 2011. p.83.

${ }^{749}$ BARBOSA, Julianna Nunes Targino. A culpabilidade na responsabilidade penal da pessoa jurídica. Faculdade de Direito, Universidade de São Paulo, São Paulo, 2014. p.32-33.

${ }^{750}$ BRODOWSKI, Dominik; ESPINOZA DE LOS MONTEROS DE LA PARRA, Manuel; TIEDEMANN, Klaus. op.cit. p.02.

${ }^{751}$ BARBOSA, Julianna Nunes Targino. op.cit. p.157.

${ }^{752}$ BARBOSA, Julianna Nunes Targino. op.cit. p.17.
} 
doutrina dominante espanhola também reconhece a importância político-criminal das sanções diretas aos agrupamentos ou coletivos de pessoas como uma forma de combate à criminalidade empresarial $^{753}$. Ainda que a infração delitiva seguisse como algo exclusivo da pessoa física, as necessidades político-criminais determinariam a importância de ser instaurado um sistema paralelo de prevenção de delitos e, desta forma, responderiam as empresas por terem favorecido, com seu déficit de organização, a prática dos delitos. O resultado esperado seria assegurar que as próprias empresas buscassem a autorregulação, como a melhor forma de controle ${ }^{754}$.

Nas palavras de Coffee $\mathrm{Jr}$, quanto mais predatória e oportunista for uma sociedade, mais estas experiências vão influenciar o comportamento das corporações ${ }^{755}$. Em um ambiente em que a violação de leis seja endêmica, não se pode esperar que as empresas ajam em compliance com a lei, e neste contexto, agir de acordo com a lei será com o objetivo de agregar maior valor de mercado aos seus produtos e serviços ${ }^{756}$. Coffee Jr conclui que leis rígidas não são suficientes, se não forem implementadas de forma eficiente, e para que as empresas façam efetivamente parte da sociedade, a confiança deve ser promovida e aperfeiçoada pelo ambiente ${ }^{757}$. Afirma o autor que na falta de proteções legais, os investidores passam a depender mais de conexões do que da lei, sendo que o correto seria que suas expectativas fossem devidamente garantidas pela lei e pela confiança $^{758}$.

Tal responsabilidade pode ser vista como uma tentativa do Estado em buscar a cooperação das empresas na prevenção e investigação de determinadas formas de delinquência empresarial ${ }^{759}$. A política e a teoria criminal precisam estar alinhadas com o

\footnotetext{
${ }^{753}$ SILVA SÁNCHEZ, Jesús-María. Responsabilidad penal de las empresas y de sus organos en derecho español. In: PRADO, Luiz

Regis; DOTTI, René Ariel (coord.). Responsabilidade penal da pessoa jurídica: em defesa do princípio da imputação penal subjetiva. 4. ed. São Paulo: Revista dos Tribunais, 2013.p.70.

${ }^{754}$ COCA VILA, Ivó. ¿Programas de cumplimiento como forma de autorregulación regulada? In: MONTANER FERNÁNDEZ, Raquel (coord.). Criminalidad de empresa y compliance. Prevención y reacciones corporativas. Barcelona: Atelier, 2013. p.65.

${ }^{755}$ COFFEE JR, John C. Do norms matter? A cross-country evaluation.p. 2169.

${ }^{756}$ COFFEE JR, John C. op.cit. p.2171-2172.

${ }^{757}$ COFFEE JR, John C. op.cit. p.2176-2177.

${ }^{758}$ COFFEE Jr, John C. The future as history: the prospects for global convergence in corporate governance and its implications. 93, Northwestern University Law Review, 641. 1999.p.137-139.

${ }^{759}$ NIETO MARTÍN, Adán. Regulatory Capitalism y cumplimiento normativo. In: ARROYO ZAPATERO, Luis; NIETO MARTÍN, Adán (coord.). El derecho penal en la era compliance. Valencia: Tirant lo Blanch, 2013. p.19.
} 
direito constitucional e com a cultura criminal, ou seja, os valores sociais e circunstâncias específicas de cada sociedade ${ }^{760}$.

O mesmo legislador que exige um efetivo e complexo controle por parte das empresas, não estabelece quais os limites e quesitos exigíveis ${ }^{761}$. Neste contexto, não cabe ao Estado apenas a função do "porrete" ao final do processo. Empresas com programas de compliance sólidos e bem implementados podem evitar punições caso colaborem com as investigações e sanções mais brandas, como o aperfeiçoamento do programa, a mudança de diretores ou uma supervisão judicial que busque auxiliar a empresa a aperfeiçoar suas práticas de boa governança trariam maior credibilidade ao sistema ${ }^{762}$.

O defeito de organização da empresa ocorre quando esta não adota uma organização correta, o que daria ensejo a responsabilizações e sanções. As atividades de uma empresa orientadas unicamente para o lucro dificultam a individualização de condutas $^{763}$, uma vez que o delito cometido dentro da empresa surge como um produto da decisão de uma ou várias pessoas a partir de uma atitude criminógena do ambiente que disponibiliza os meios necessários para alcançá-1o ${ }^{764}$. Conforme explica Coffee Jr, a ação em grupo dentro de uma empresa resultaria em decisões mais arriscadas do que se um único indivíduo ponderasse as informações recebidas ${ }^{765}$.

Entende Juan Antonio Lascuraín que tendo como contexto o forte caráter simbólico do direito penal, caberia à pessoa jurídica responder por delitos realizados através de seus mecanismos de decisão, por não ter tomado os devidos cuidados em seu modo de produção e ter falhado em neutralizar as condutas criminógenas ${ }^{766}$. Para o autor, exercer um devido

\footnotetext{
${ }^{760}$ TIEDEMANN, Klaus. Corporate Criminal Liability as a Third Track. p.13.Neste sentido Silva Sánchez traz que "a sanção penal possui um valor simbólico inegável e de máxima relevância negativa para a empresa, o que determina uma eficácia preventiva, sem dúvida, maior”. SILVA SÀNCHEZ, Jesús-María. Responsabilidad penal de las empresas y de sus organos en derecho español. In: PRADO, Luiz Regis; DOTTI, René Ariel (Coord.). Responsabilidade penal da pessoa jurídica: em defesa do princípio da imputação penal subjetiva. 4. ed. São Paulo: Revista dos Tribunais, 2013.p.76.

${ }^{761}$ NIETO MARTÍN, Adán. op.cit. p.23.

${ }^{762}$ NIETO MARTÍN, Adán. op.cit. p.21-22.

${ }^{763}$ BARBOSA, Julianna Nunes Targino. A culpabilidade na responsabilidade penal da pessoa jurídica. Faculdade de Direito, Universidade de São Paulo, São Paulo, 2014. p.28.

${ }^{764}$ SILVA SÀNCHEZ, Jesús-María. Responsabilidad penal de las empresas y de sus organos en derecho español. In: PRADO, Luiz Regis; DOTTI, René Ariel (Coord.). Responsabilidade penal da pessoa jurídica: em defesa do princípio da imputação penal subjetiva. 4. ed. São Paulo: Revista dos Tribunais, 2013.p.76.

${ }^{765}$ COFFEE JR, John C. Corporate Crime and Punishment: a non-Chicago view of the economics of criminal sanctions. American Criminal Law Review, vol.17, 1980. p.433.

${ }^{766}$ LASCURAÍN, Juan Antonio. Compliance, debido control y unos refrescos. In: ARROYO ZAPATERO, Luis (dir.). NIETO MARTÍN, Adán (dir.). El derecho penal económico en la era compliance. Valência: Ed. Tirant lo Blanch, 2013. p.117-119.
} 
controle sobre suas atividades exige da empresa agir de forma razoável para evitar riscos não permitidos e evitar que aqueles que sejam permitidos não excedam o limite do tolerável $^{767}$.

Uma sanção criminal é considerada muito mais dissuasiva quando comparada com uma multa administrativa e a estigmatização mais forte, resultante das medidas penais, reflete de forma mais impactante na percepção pública não só em relação à empresa ${ }^{768}$, mas também sobre os delinquentes de colarinho-branco ${ }^{769}$. Às sanções penais, Silva Sánchez atribui três funções: a compensação do efeito criminógeno que a empresa exerce sobre aqueles integrados à sua atividade; as situações de impunidade produzidas diante da dificuldade de um autor concreto ser determinado e de atender ao fato de que, muitas vezes, a conduta delitiva é autenticamente coletiva ${ }^{770}$.

Para Klaus Tiedemann, a limitação histórica dos sistemas criminais em torno do direito penal liberal baseado no indivíduo encontra-se ultrapassado, quando consideramos a atual realidade social: as corporações representam um dos principais e mais complexos atores econômicos ${ }^{771}$. O autor cita que, em países como Suécia e Suíça, as empresas podem se eximir de culpa caso tenham tomado todas as medidas preventivas possíveis contra os crimes relacionados à empresa como, por exemplo, programas de compliance $\mathrm{e}$ códigos de ética corporativos ${ }^{772}$. Tiedemann entende a responsabilidade das pessoas jurídicas como um terceiro caminho no direito penal para a punição e incapacitação dos ofensores incapazes de serem considerados culpados. A partir do conceito de culpabilidade por defeito de organização, "sustentou que a culpabilidade necessária para a incriminação das pessoas jurídicas seria menos intensa do que a que o direito penal clássico exige, na medida em que redunda em multa e não em pena em sentido forte ${ }^{773}$ ". As sanções

\footnotetext{
${ }^{767}$ LASCURAÍN, Juan Antonio. op.cit. p.125.

${ }^{768}$ TIEDEMANN, Klaus. op.cit. p. 14.

${ }^{769}$ COFFEE JR, John C. op.cit. p.432.

${ }^{770}$ SILVA SÀNCHEZ, Jesús-María op.cit. p.76-77.

${ }^{771}$ TIEDEMANN, Klaus. op.cit. p.16.

${ }^{772}$ TIEDEMANN, Klaus. op.cit. p.16.Neste sentido, a cultura corporativa do compliance pode ser encorajada pelo Estado e uma espécie de ameaça pela responsabilização da pessoa jurídica, ao mesmo tempo que a lógica da recompensa é aplicada aos programas bem formulados. BRODOWSKI, Dominik; ESPINOZA DE LOS MONTEROS DE LA PARRA DE LA PARRA, Manuel; TIEDEMANN, Klaus. Regulating Corporate Criminal Liability: an introduction. In: BRODOWSKI, Dominik; ESPINOZA DE LOS MONTEROS DE LA PARRA DE LA PARRA, Manuel; TIEDEMANN, Klaus (ed.). Regulating corporate criminal liability. Heidelberg: Springer, 2014. p. 03.

${ }^{773}$ TANGERINO, Davi de Paiva Costa. Culpabilidade e responsabilidade penal da pessoa jurídica. Revista Brasileira de Ciências Criminais, São Paulo, v. 18, n. 86, set./out. 2010. p. 48.
} 
administrativas, para o autor, somente poderiam ser dissuasivas e efetivas em grandes julgamentos públicos ${ }^{774}$.

O conjunto de medidas estabelecidas pelos programas de compliance exige que as empresas contem com uma organização adequada que trabalhe de forma eficaz na prevenção das condutas delitivas e faça da empresa uma boa cidadã corporativa, regida pelas normas legais ${ }^{775}$. Pondera Nieto Martín que "a existência de um delito cometido por uma pessoa jurídica como consequência de um defeito de organização, de um programa de cumprimento defeituoso ou mal implementado, constitui o núcleo da ofensa na grande maioria dos ordenamentos que estabelecem a responsabilidade penal das pessoas jurídicas ${ }^{776,}$.

Em muitos países, as sanções administrativas necessitam apenas de culpa social e não da culpa individual e ética e, portanto, podem ser consideradas um meio mais apropriado para combater os crimes corporativos ${ }^{777}$. Entende-se necessário repensar a justiça criminal corporativa e olhar além da questão da vinculação da responsabilidade penal à dogmática penal atual ${ }^{778}$.

Sérgio Salomão Shecaira ${ }^{779}$ afirma que as questões político-criminais no âmbito corporativo modificam-se com o protagonismo das grandes empresas comerciais ${ }^{780}$. A

\footnotetext{
${ }^{774}$ TIEDEMANN, Klaus. Corporate Criminal Liability as a Third Track. p.17.

${ }^{775}$ NIETO MARTÍN, Adán. Problemas fundamentales del cumplimiento normative en el derecho penal. In: KUHLEN, Lothar (ed.). MONTIEL, Juan Pablo (ed.). ORTIZ DE URBINA GIMENO, Iñigo (ed.). Compliance y teoria del derecho penal. Madrid: Marcial Pons, 2013. p.30-31.

${ }^{776}$ NIETO MARTÍN, Adán. op.cit. p.32.

${ }^{777}$ TIEDEMANN, Klaus. op.cit. p.13.

${ }^{778}$ BRODOWSKI, Dominik; ESPINOZA DE LOS MONTEROS DE LA PARRA, Manuel; TIEDEMANN, Klaus. op.cit. p. 06.

${ }^{779}$ Em seu livro, Responsabilidade Penal da Pessoa Jurídica, Sérgio Salomão Shecaira elenca argumentos contrários à responsabilidade da pessoa jurídica e explica os motivos pelos quais eles estariam errados. $\mathrm{O}$ primeiro é que não há responsabilidade sem culpa e, considerando a pessoa jurídica desprovida de inteligência e vontade, seria incapaz de cometer um crime, devendo recorrer a pessoas físicas. A culpa é, para Shecaira, "uma base filosófica do Direito penal, de que se parte para legitimar o direito de punir comportamentos que põem em perigo ou atingem bens juridicamente relevantes". No contexto de uma denominada "ação institucional", haveria uma vontade pragmática da empresa, que, destinatária de deveres jurídicos, poderia, da mesma forma, lesioná-los. O segundo seria a transposição às pessoas jurídicas do principio da personalidade das penas, uma vez que uma condenação poderia atingir pessoas inocentes, como trabalhadores e sócios minoritários, por exemplo. Infelizmente, tal princípio já se mostra descumprido, por exemplo, no caso de um pai de família, provedor, que por algum motivo é preso. Seus familiares vão sofrer com tal prisão, psicológica e financeiramente, sendo aparados, inclusive, pela legislação previdenciária e de execução penal que permite que o preso envie parte dos rendimentos obtidos trabalhando no cárcere para sua família. Trazendo a discussão para a pessoa jurídica, no caso de uma multa civil ou administrativa, da mesma forma seriam atingidos sócios minoritários ou outros que não participaram das decisões. Também é questionada a aplicação da pena privativa de liberdade para as empresas. Shecaira explica que o melhor para o sistema penal não se tornar autoritário é que a pena privativa de liberdade seja utilizada como ultima ratio no direito penal. Se considerarmos, inclusive, as precárias situações carcerárias e as funções da pena, não
} 
insuficiência do atual direito penal em lidar com os crimes vinculados às empresas seria clara diante das características das corporações dotadas de "organismos sociais e técnicos diversos das somas de homens e recursos que contribuam para a consecução de suas atividades $^{781}$ ". O direito penal é constantemente desafiado a trazer respostas eficazes às ofensas e ameaças aos bens jurídicos, desde que não comprometam sua identidade, princípios ou características fundamentais ${ }^{782}$. Erika Mendes de Carvalho e Gisele Mendes de Carvalho afirmam não ser tarefa do direito penal compensar as debilidades funcionais de outros ramos jurídicos, não justificando "o abandono das escrupulosas regras de imputação penal subjetiva e individual ${ }^{783}$,", mas que a prevenção, em contextos empresariais, poderia ser alcançada com o fortalecimento do Direito Administrativo Sancionador ${ }^{784}$.

De acordo com o art. $173, \S 5^{\circ}$, "a lei, sem prejuízo de responsabilidade individual dos dirigentes da pessoa jurídica, estabelecerá a responsabilidade desta, sujeitando-a às punições compatíveis com sua natureza, nos atos praticados contra a ordem econômico e financeira e contra a economia popular”. Para Shecaira, há autorização constitucional para a adoção do sistema de dupla imputação tanto nos crimes contra a ordem econômica e financeira e contra a economia popular, quanto nos crimes contra o meio ambiente ${ }^{785}$. A pena a ser aplicada é a pena pecuniária, a multa, que deve ser majorada em um "valor superior ao benefício que a empresa obteve eventualmente com o delito ${ }^{786 \%}$.

Ainda que a empresa seja o resultado das sucessivas decisões de seus agentes, os lucros obtidos com elas serão aproveitados pela empresa. Coffee $\mathrm{Jr}$ entende que a ameaça dissuasiva funciona melhor com os agentes do que com a empresa, uma vez que não

faria sentido a pena privativa de liberdade para a ressocialização de pessoas já altamente socializadas e integradas na sociedade. Por último é trazido o argumento de que a pessoa jurídica seria incapaz de arrepender-se e não conseguiria, da mesma forma, ser intimidada ou reeducada. $\mathrm{O}$ autor afirma que, um dos principais objetivos da pena é reprovar a conduta em conflito, por sua relevância pública e não objetivos morais. SHECAIRA, Sérgio Salomão. Responsabilidade Penal da Pessoa Jurídica. 3.ed. Rio de Janeiro: Elsevier, 2011. p.97-101.

${ }^{780}$ SHECAIRA, Sérgio Salomão. Responsabilidade penal das pessoas jurídicas. In: OLIVEIRA, William Terra de (Org.) et al. Direito penal econômico: estudos em homenagem aos 75 anos do Professor Klaus Tiedemann. São Paulo: LiberArs, 2013. p.350.

${ }^{781}$ SHECAIRA, Sérgio Salomão. op.cit. p.101.

${ }^{782}$ CARVALHO, Érika Mendes. CARVALHO, Gisele Mendes. Direito Penal de Risco e Responsabilidade Penal das Pessoas Jurídicas: a propósito da orientação jurisprudencial do Superior Tribunal de Justiça. PRADO, Luiz Regis; DOTTI, René Ariel (Coord.). Responsabilidade penal da pessoa jurídica: em defesa do princípio da imputação penal subjetiva. 4. ed. São Paulo: Revista dos Tribunais, 2013.p. 254.

${ }^{783}$ CARVALHO, Érika Mendes. CARVALHO, Gisele Mendes. op.cit. p.255.

${ }^{784}$ CARVALHO, Érika Mendes. CARVALHO, Gisele Mendes. op.cit. p.271.

${ }^{785}$ SHECAIRA, Sérgio Salomão. op.cit. p. 355.

${ }^{786}$ SHECAIRA, Sérgio Salomão. op.cit. p. 356. 
haveria equivalente monetário à pena privativa de liberdade ${ }^{787}$. Para o autor, a empresa para ser punida por crimes corporativos dependeria de três fatores: da eficiência do mercado no controle corporativo; de respostas internas disciplinárias e da dificuldade de reentrada dos executivos demitidos no mercado $^{788}$.

A infração praticada deverá ser realizada no interesse da pessoa coletiva, em sua esfera de atividade, por alguém estreitamente ligado à pessoa coletiva e o poderio oculto nela, resultando este da "reunião de forças econômicas" ${ }^{789 ", ~ C o n f o r m e ~ e x p l i c a ~ N i e t o ~}$ Martín, a culpabilidade da empresa seria um problema de management permanente, uma vez que a implementação e a eficácia do programa de compliance aplicado pela empresa envolveria a formação dos funcionários, canais de denúncia efetivos, sanções disciplinarias internas e a revisão e adaptação do programa diante de possíveis falhas, bem como a existência de medidas de prevenção para fatos similares a estas falhas, como o desenvolvimento de um standard de medidas específicas e uma preocupação com a implementação de uma cultura de legalidade ${ }^{790}$.

A responsabilização penal das pessoas jurídicas teria desta forma, uma função meramente simbólica e seu uso exagerado acarretaria a impunidade de indivíduos responsáveis $^{791}$. Considerando a culpabilidade, o modelo brasileiro de responsabilização da pessoa jurídica, fortemente ligado ao binômio culpa-pena, o faz por meio de um modelo de responsabilização objetiva, resultante da responsabilidade de uma pessoa física ${ }^{792}$. A culpabilidade da empresa seria, portanto, a expressão de um caráter empresarial defeituoso, quando não consegue organizar e desenvolver seus objetivos de forma eficaz ${ }^{793}$. A implementação defeituosa ou a não implementação de um programa de compliance, nesta visão, trariam a suposição de um favorecimento imprudente ao cometimento de um delito por um autor individual, bem como a ocorrência de um risco não permitido ${ }^{794}$. Neste sentido, explica Renato Silveira que "como o pensamento tradicional não aceita uma

\footnotetext{
${ }^{787}$ COFFEE JR, John C. Corporate Crime and Punishment: a non-Chicago view of the economics of criminal sanctions. American Criminal Law Review, vol.17, 1980. p.456.

${ }^{788}$ COFFEE JR, John C. op.cit. p.469.

${ }^{789}$ SHECAIRA, Sérgio Salomão. Responsabilidade Penal da Pessoa Jurídica. 3.ed. Rio de Janeiro: Elsevier, 2011. p.105.

${ }^{790}$ NIETO MARTÍN, Adán. Problemas fundamentales del cumplimiento normative en el derecho penal. In: KUHLEN, Lothar (ed.). MONTIEL, Juan Pablo (ed.). ORTIZ DE URBINA GIMENO, Iñigo (ed.). Compliance y teoria del derecho penal. Madrid: Marcial Pons, 2013. p.39.

${ }^{791}$ CARVALHO, Érika Mendes. CARVALHO, Gisele Mendes. op.cit. p.259.

${ }^{792}$ TANGERINO, Davi de Paiva Costa. Culpabilidade e responsabilidade penal da pessoa jurídica. Revista Brasileira de Ciências Criminais, São Paulo, v. 18, n. 86, set./out. 2010. p.47.

${ }^{793}$ TANGERINO, Davi de Paiva Costa op.cit. p.52.

${ }^{794}$ NIETO MARTÍN, Adán. op.cit. p.37.
} 
independência de atuação da pessoa jurídica, somente pode imagina-la culpável se houver uma correspondente culpa individual ${ }^{795}$,

O Estado busca a cooperação das empresas como uma forma de conter e prevenir os riscos e estabelecer técnicas de regulação adequadas às estruturas empresariais ${ }^{796}$. Entretanto, diante desta transferência para o interior das empresas de "standards de cuidados públicos ${ }^{797}$,", para que as empresas possam gerenciar suas atividades, é preciso que haja obrigações e deveres pré-estabelecidos pela regulamentação. Tais garantias precisam ser delineadas de forma que as empresas assumam suas posições de autocontrole e prevenção, sem cair no problema bem sublinhado por Adán Nieto Martín do paradoxo entre maiores informações obtidas pelos mecanismos internos dando ensejo a maiores responsabilidades no âmbito penal ${ }^{798}$.

Para Joachim Vogel ${ }^{799}$, é necessária uma nova forma de pensarmos a responsabilidade criminal das empresas a partir de estudos empíricos e políticas criminais, uma vez que faltam informações sobre os principais delitos cometidos por empresas, quantas e quais seriam estas empresas, bem como o tipo de sanção sofrida quando condenadas.

Juan Antonio Lascuraín entende como uma saída a não imputação, acusação ou condenação de empresas que estejam bem organizadas ${ }^{800}$. Neste sentido, Leandro Sarcedo traz a importante observação de que "é preciso criar um novo paradigma no sentido de que a eficiência e a efetividade do programa de compliance possam ser valorados ex-ante", cabendo ao julgador analisar o então comprometimento das empresas com o Direito ${ }^{801}$.

\footnotetext{
${ }^{795}$ SILVEIRA, Renato de Mello Jorge; SAAD-DINIZ, Eduardo. Compliance, Direito Penal e Lei Anticorrupção. São Paulo: Saraiva, 2015. p.172.

${ }^{796}$ BARBOSA, Julianna Nunes Targino. A culpabilidade na responsabilidade penal da pessoa jurídica. Faculdade de Direito, Universidade de São Paulo, São Paulo, 2014. p.36.

${ }^{797}$ LASCURAÍN, Juan Antonio. Compliance, debido control y unos refrescos. In: ARROYO ZAPATERO, Luis (dir.). NIETO MARTÍN, Adán (dir.). El derecho penal económico en la era compliance. Valência: Ed. Tirant lo Blanch, 2013.p.129.

${ }^{798}$ NIETO MARTÍN, Adán. El programa politico-criminal del corporate goverment: derecho penal de la empresa y gobierno corporativo. Revista Aranzadi de derecho y proceso penal, Navarra, n. 11, 2004. p. 267.

${ }^{799}$ VOGEL, Joachim. Rethinking Corporate Criminal Liability. In: BRODOWSKI, Dominik; DE LA PARRA, Manuel Espinoza de los Monteros; TIEDEMANN, Klaus (ed.). Regulating corporate criminal liability. Heidelberg: Springer, 2014. p.337.

${ }^{800}$ LASCURAÍN, Juan Antonio. op.cit. p.133.

${ }^{801}$ SARCEDO, Leandro. Compliance e Responsabilidade Penal da Pessoa Jurídica: Construção de um novo modelo de imputação, baseado na culpabilidade corporativa. Faculdade de Direito, Universidade de São Paulo, São Paulo, 2014. p.258.
} 
Como reflexo direto das normas de autorregulação, a empresa deve assegurar o descobrimento de comportamentos indesejados, através de controles de seus números, avaliação dos riscos, de acordo com as especificidades de sua área empresarial, considerando aqui fatores geográficos e mesmo interações com governos estrangeiros ${ }^{802}$. Nas palavras de Marta Muñoz de Morales Romero, a atenuação da responsabilidade penal ou mesmo sua exclusão somente será possível após a avaliação do programa de compliance demonstrar que se trata de "uma exitosa ferramenta de direção e gestão que demonstre a capacidade para prevenir, detectar e remediar não cumprimentos que podem ocorrer no cotidiano dos negócios empresariais ${ }^{803 "}$.

Como desdobramento das considerações sobre a efetividade e eficiências dos programas de cumprimento, chegamos a uma breve discussão sobre a certificação destes, se seria uma forma de garantir às empresas boas práticas, e mesmo uma maior garantia contra a responsabilização penal. Jean Pierre Matus Acuña traz o exemplo do modelo de certificação chileno, presente na Lei n.20.393/2009 ${ }^{804}$. No Chile, a lei trouxe algumas especificações sobre o que se espera do programa de cumprimento a ser aplicado pelas empresas, considerando a possibilidade de que este programa seja submetido a um processo de certificação, de acordo com as características da empresa, que vai indicar se

\footnotetext{
${ }^{802}$ MORALES ROMERO, Marta Muñoz de. Programas de cumplimiento "efectivos" en la experiência comparada. In: ARROYO ZAPATERO, Luis; NIETO MARTÍN, Adán (org) El derecho penal económico en la era compliance. Valencia: Tirant lo Blanch, 2013. p.226.

${ }^{803}$ MORALES ROMERO, Marta Muñoz de. op.cit. p. 215.

${ }^{804}$ A lei chilena dispõe sobre a responsabilidade penal das pessoas jurídicas nos crimes de lavagem de dinheiro, financiamento de terrorismo e delitos de corrupção. Será atribuída responsabilidade penal para as pessoas jurídicas que sejam responsáveis pelos delitos cometidos, direta e indiretamente em seu interesse ou proveito, por seus donos, controladores, responsáveis, executivos principais, representantes ou aqueles que realizem atividades de administração e supervisão, sempre que tais delitos sejam consequência do descumprimento dos deveres de direção e supervisão. A lei considera cumpridos os deveres de direção e supervisão quando, com anterioridade à comissão dos delitos, a pessoa jurídica tiver adotado e implementado modelos de organização, administração e supervisão para prevenir delitos (artigo $3^{\circ}$ ). Define a lei que o modelo de prevenção adotado pela empresa deverá ter um encarregado, por um prazo estabelecido (três anos prorrogáveis por mais três), dotado de autonomia para desempenhar suas funções, bem como recursos e meios materiais necessários para exercê-las. Serão implementadas a identificação de atividades e processos, habituais ou esporádicos, em cujo contexto haja um incremento dos riscos assumidos pela empresa; o estabelecimento de protocolos, regras e procedimentos específicos que busquem programar e executar tarefas de uma forma que previna a comissão dos mencionados delitos. É importante que o programa conte com procedimentos de auditoria dos recursos financeiros e sanções administrativas internas. Estabelece a lei que o encarregado pela prevenção deverá, em conjunto com a Administração da Pessoa Jurídica, estabelecer métodos para a aplicação efetiva do programa, supervisionando-o e corrigindo falhas que possam vir a surgir. Uma forma de garantir um melhor andamento dos programas de prevenção é que as pessoas jurídicas obtenham sua certificação de adoção e implementação do programa, de acordo com o seu tamanho, atividade e complexidade (artigo $4^{\circ}$ ). Disponível em $<$ http://www.leychile.cl/Navegar?idNorma=1008668 $>$. Acesso em 29 de janeiro de 2016.
} 
contempla todos os requisitos estabelecidos em lei ${ }^{805}$. De acordo com a lei chilena, os certificados podem ser expedidos por empresas de auditoria externa, sociedades classificadoras de risco ou outras entidades registradas na Superintendência de Valores e Seguros, e terá a validade de 02 anos, evidenciado aqui a necessidade da constante avaliação e atualização dos programas de compliance.

Entende Matus Acuña que tais certificações poderiam ser consideradas como provas em favor da empresa, caso necessário, atestando seus esforços para agir como um bom cidadão corporativo, e servindo de atenuação da responsabilidade penal. E que, num futuro próximo, tais certificações passarão a ser exigidas para o desenvolvimento de certas atividades econômicas ${ }^{806}$. Para Adán Nieto Martín, a resposta não parece estar nas certificações dos programas existentes, pois, uma vez mais, cria-se o perigo de criar um mercado interessado em oferecer "certificados de boa conduta" e empresas que vejam nestes um reforço para um seguro antimultas ${ }^{807}$.

Buscando evitar mais um objetivo de fachada não só para os programas de compliance, mas também para as certificações destes, seria importante um sistema geral e detalhado, com o objetivo de auditar estes programas, seus pontos fortes e fracos e, ao mesmo tempo, trazer ao sistema segurança jurídica, por exemplo, com standards de auditoria $^{808}$.

Para Laufer, a responsabilidade das empresas deve ser reconceitualizada de forma que os diretores sejam realmente independentes; as divulgações de impactos ambientais e sociais feitas; decisões tomadas de forma razoável e ponderada; canais internos garantidos e sanções para executivos e empresas aperfeiçoadas ${ }^{809}$. O autor sugere que as empresas sejam classificadas de acordo com a opacidade (nível de obscuridade das informações e atividades), transparência (abertas, com boa comunicação), sinceridade e autenticidade

\footnotetext{
${ }^{805}$ MATUS ACUÑA, Jean Pierre. La certificación de los programas de cumplimiento. In: ARROYO ZAPATERO, Luis (dir.). NIETO MARTÍN, Adán (dir.). El derecho penal económico en la era compliance. Valência: Ed. Tirant lo Blanch, 2013. p.145-146.

${ }^{806}$ MATUS ACUÑA, Jean Pierre. op.cit. p.151-153.

${ }^{807}$ NIETO MARTÍN, Adán. Regulatory Capitalism y cumplimiento normativo. In: ARROYO ZAPATERO, Luis; NIETO MARTÍN, Adán (coord). El derecho penal en la era compliance. Valencia: Tirant lo Blanch, 2013. p.25.

${ }^{808}$ GONZÁLEZ FRANCO, José Ángel; SCHEMMEL Alexander; BLUMENBERG, Axel. La función del penalista en la confección, implementación y evaluación de los programas de cumplimiento. In: In: ARROYO ZAPATERO, Luis (dir.). NIETO MARTÍN, Adán (dir.). El derecho penal económico en la era compliance. Valência: Ed. Tirant lo Blanch, 2013.p.157.

${ }^{809}$ LAUFER, William S. op.cit. p.29.
} 
(decisões alinhadas com boas motivações e intenções) ${ }^{810}$. É possível perceber que mesmo nas empresas onde os responsáveis pela área de compliance conseguem realizar programas de ética e treinamento, pouco é feito para dar-lhes eficácia ${ }^{811}$.

Assim, é importante que o contexto social seja modificado e as boas práticas internalizadas pelos atores sociais e econômicos, de forma que as mudanças sejam desejadas com o objetivo de desenvolver um ambiente mais ético para os negócios ${ }^{812}$. $\mathrm{O}$ reconhecimento de que não podemos cair nos pêndulos de regulamentação vem acompanhado do fato de que os sistemas não são perfeitos, mas devem ser aprimorados conforme as novas atividades se desenvolvem ${ }^{813}$.

Assim, os comportamentos do mercado e das empresas também serão significativos para a prevenção dos crimes econômicos. Conforme afirma Coffee Jr, a ideia de que "o comportamento empresarial pode ser mais ajustado e determinado por normas sociais do que por regras legais parece ter ganhado forças ${ }^{814}$ ". Explica o autor que as regras jurídicas encontram-se incorporadas em uma "matriz de normas e práticas convencionais que interagem e reforçam umas as outras" como, por exemplo, os estatutos corporativos que especificam um padrão de conduta podem ser mais rigorosos do que aqueles exigidos por $1 \mathrm{ei}^{815}$

Sabemos que o mercado, as diferentes empresas e as instituições financeiras possuem condutas internalizadas que não serão modificadas de forma impositiva. Este é o entendimento também de Eduardo Saad-Diniz quando afirma que melhor do que a intimidação seria a mobilização de "esforços para fazer florescer uma melhor performance orientada pela simetria de informações ${ }^{816,}$.

\footnotetext{
${ }^{810}$ LAUFER, William S. O compliance game. In: SAAD-DINIZ, Eduardo (org.); BRODOWSKI, Dominik (org.); SÁ, Ana Luiza de (org.). Regulação do abuso no âmbito corporativo: o papel do direito penal na crise financeira. São Paulo: Editora LiberArs, 2015.p.65.

${ }^{811}$ LAUFER, William S. op.cit. p.111.

${ }^{812}$ STOUT, Lynn. Cultivating Conscience: how good laws make good people. Princeton University Press, 2010.P. 228.

${ }^{813}$ HOLMSTROM, Bengt; KAPLAN, Steven N. The State of U.S. Corporate Governance: what's right and what's wrong. Finance Working Paper, n.23, 2003.p.29.

${ }^{814}$ COFFEE JR, John C. Do norms matter? A cross-country evaluation.p. 2151.

${ }^{815}$ COFFEE JR, John C. op.cit. p. 2156.

${ }^{816}$ SAAD-DINIZ, Eduardo. Regulação privada: há ainda alternativas para a prevenção à corrupção $e$ proteção de direitos humanos no âmbito corporativo? In: SAAD-DINIZ, Eduardo (org.); BRODOWSKI, Dominik (org.); SÁ, Ana Luiza de (org.). Regulação do abuso no âmbito corporativo: o papel do direito penal na crise financeira. São Paulo: Editora LiberArs, 2015. p.83.
} 
Os marcos regulatórios americano e britânico, conforme analisados, predispõem de normas de responsabilização das pessoas jurídicas pela ausência de uma organização adequada que poderia ter evitado a conduta ilegal. No Brasil, entende-se que a regulação tende a acompanhar a evolução espanhola, que passou a responsabilizar as organizações como forma de evitar que elas não sejam utilizadas como instrumentos delitivos, exigindose destes programas de prevenção de acordo com sua complexidade e características. Melhor do que a ameaça das sanções penais, seria a introdução de condutas éticas nas práticas negociais, com estruturas de organização que protejam os interesses dos stakeholders das práticas fraudulentas e corruptivas ${ }^{817}$. Há uma grande ênfase nas práticas de reabilitação, aumentando a importância das práticas de compliance $^{818}$, devendo a política criminal ser aplicada de forma interligada com políticas financeiras e econômicas.

${ }^{817}$ SAAD-DINIZ, Eduardo. op.cit. p.87-88.

${ }^{818}$ VOGEL, Joachim. op.cit. p. 338. 


\section{CONCLUSÕES}

1. Os casos Enron, WorldCom e Lehman Brothers evidenciaram que o problema das fraudes e especulações financeiras abrange o sistema como um todo, o Estado, as empresas, instituições financeiras, auditorias, credores, investidores e consumidores. Condutas egoístas, gananciosas e autoritárias foram lastreadas por governanças internas frágeis, não observação de práticas de prevenção e erros nas avaliações dos riscos.

2. Vivemos um período de globalização do mundo, em que as fronteiras e a noção do tempo modificaram-se radicalmente. Os processos de modernização e a rápida expansão do capitalismo além das fronteiras nacionais desenvolvem-se de forma desigual. Ao mesmo tempo em que podemos observar uma homogeneização de práticas comerciais, o ordenamento de cada Estado será desenvolvido de formas diferentes, uma vez que a lógica de uma sociedade global não absorve as diferentes nações e culturas.

3. O atual momento do direito penal caracteriza-se à prevenção e às práticas omissivas, com novas condutas criminalizadas como forma de assegurar políticas econômicas e de trazer respostas simbólicas, especialmente após casos de fraudes que envolveram toda a sociedade mundial. Entretanto, a utilização do direito penal como o "porrete" para más administrações corporativas insiste em uma lógica repressiva que já se mostrou ineficiente. Os marcos regulatórios mostram uma expansão do direito penal que deve ser utilizada com cautela, especialmente quando garantias e princípios passam a ser relativizados.

4. A complexidade das atividades econômicas e do volume de informações produzido pelas empresas são refletidos nos marcos regulatórios. Conforme estudado nos três casos, grandes fraudes repercutem em toda sociedade, sendo necessário, portanto, que todo o sistema esteja integrado. Os marcos regulatórios analisados mostram que os Estados evidenciam um esforço para regular as atividades negociais, controlar os riscos excessivos e investir em mecanismos de prevenção. Buscando 
restaurar o equilíbrio e a confiança no sistema, as normas focam em procedimentos como transparência, enforcement, monitoramento e supervisão dos programas de compliance.

5. Diante da incapacidade do Estado em regular todas as atividades empresariais, da complexidade e especificidade destas, cabe às empresas esta aliança em prol de um mercado mais ético e confiável. Esta nova estratégia, da autorregulação regulada, coloca em prática medidas de controle e boa governança implementadas pelas próprias empresas, que a partir de Códigos de ética, auditorias internas, canais de denúncia e proteção dos interesses de todos os stakeholders, rompem com a ideia de lucro a todo custo, administrando seus riscos e prevenindo condutas delituosas.

6. As práticas de compliance trazem uma série de diretivas que devem ser aplicadas nas atividades desenvolvidas na prática empresarial e, neste sentido, é necessário que existam padrões delimitados pelo Estado ou por organizações internacionais como a OCDE para trazer maior segurança jurídica na aplicação das sanções. É preciso que sejam pré-estabelecidos requisitos normativos que tragam garantias e parâmetros de deveres mínimos a serem adotados pelas empresas, bem como situações de cooperação com as investigações criminais, de forma a assegurar que os programas de compliance implementados não se tornem uma expansão punitiva do Estado.

7. Os programas de compliance, a avaliação de riscos e a governança corporativa crescem e fortalecem-se como formas de incutir no mercado as boas práticas e um desenvolvimento sustentável da produção, respeitando a todos os stakeholders. Deve-se considerar, entretanto, que a necessidade de desenvolver um ambiente de confiança e segurança não pode dar espaço a dois problemas: o uso do compliance de forma superficial, sem que haja um efetivo comprometimento da empresa em agir eticamente, tendo como objetivo unicamente a diminuição de sua responsabilização; ou o uso, por parte do Estado, dos programas como uma forma de dispor de informações específicas da empresa, em uma clara expansão do direito penal, sem que tenham sido estabelecidos critérios materiais de valoração da punição. 
8. Leis rígidas e específicas demais se tornam um solo fértil para o referido compliance criativo. Neste sentido, uma regra legal específica será eficiente em um determinado contexto, mas para funcionar bem em outros mercados, deverá sofrer adaptações específicas. Por exemplo, muitas são ainda as dúvidas, no Brasil, em relação à figura de whistleblower e sua atuação na prevenção à criminalidade sem que haja a criação de um clima de denuncismo, vingança ou perda da produtividade dentro da empresa.

9. Ainda que poucos sejam os estudos que tragam efetivos resultados da aplicação dos programas de compliance, alguns já demonstram que o comprometimento das empresas com a implementação, treinamento e atualização já indicam vantagens para a difusão da cultura ética nos negócios. Para que esta lógica da prevenção evolua, é preciso que haja um comprometimento real das empresas interna e externamente, por meio de políticas públicas que evidenciem a sua importância. 


\section{BIBLIOGRAFIA}

AKERLOF, George A. The Market for "lemons": quality uncertainty and the market mechanism. Quarterly Journal of Economics, v.LXXXIV, n.3, p.488-500, Agosto de 1970.

AMBOS, Kai. "Joint criminal enterprise" y la responsabilidad del superior. Revista de Derecho Penal y Criminología: Espanha, Madrid, 2a Época, n. 19, p.39-78, jan. 2007.

AMBOS, Kai. Dominio del hecho por dominio de voluntad en virtud de aparatos organizados de poder: una valoración crítica y ulteriores aportaciones. Ciencias Penales: Revista de la Asociación de Ciencias Penales de Costa Rica, San José, v. 12, n. 17, p.2947, mar. 2000.

AMORIM, Thiago Navarro Mafra. Contingência de crises financeiras: um estudo sobre a evolução da regulação dos mercados e o risco das instituições financeiras no Brasil. Faculdade de Economia, Administração e Contabilidade. Universidade de São Paulo, 2011.

ARAUJO JUNIOR, João Marcello de. O direito penal econômico. Revista Brasileira de Ciências Criminais, São Paulo, v. 7, n. 25, p.142-156, jan./mar. 1999.

ASHKENAS, Ron. Why integrity is never easy. Harvard Business Review, 08 de fevereiro de 2011. Disponível em <https://hbr.org/2011/02/why-integrity-is-never-easy/>. Acesso em 20 de setembro de 2015.

AZEVEDO, André Mauro Lacerda. Bribery Act 2010: um novo paradigma no enfrentamento da corrupção. Revista Brasileira de Ciências Criminais, São Paulo, v. 23, n. 113, p.411-439, mar./abr. 2015.

BARBOSA, Julianna Nunes Targino. A culpabilidade na responsabilidade penal da pessoa jurídica. Faculdade de Direito, Universidade de São Paulo, São Paulo, 2014.

BASEL COMMITTEE ON BAKING SUPERVISION - Basel III: A global regulatory framework for more resilient banks and banking systems. Junho, 2011.

BECK, Ulrich. O que é globalização? Equívocos do globalismo, respostas à globalização. São Paulo: Editora Paz e Terra, 1999.

BERCOVICI, Gilberto. A influência do poder econômico sobre o poder político. Boletim IBCCRIM, São Paulo, v. 23, n. 274, p.8-9, set. 2015.

BERCOVICI, Gilberto. O Ainda Indispensável Direito Econômico. In: Maria Victoria de Mesquita Benevides; Gilberto Bercovici; Claudineu de Melo. (Org.). Direitos Humanos, Democracia e República: Homenagem a Fábio Konder Comparato. São Paulo: Quartier Latin, 2009.p. 503-519.

BERCOVICI, Gilberto. Política econômica e direito econômico. Revista da Faculdade de Direito (USP), v. 105, 2010.p. 389-406. 
BERCOVICI, Gilberto; SOUZA, Luciano Anderson de. Intervencionismo econômico e direito penal mínimo: uma equação possível. In: OLIVEIRA, William Terra de; LEITE, NETO, Pedro Ferreira; ESSADO, Tiago Cintra; SAAD-DINIZ, Eduardo (orgs.). Direito penal econômico: estudos em homenagem aos 75 anos do Professor Klaus Tiedemann. São Paulo: LiberArs, 2013.

BERRUEZO, Rafael. Derecho penal económico. In: BERRUEZO, Rafael et al. Derecho penal económico, Buenos Aires: Editorial B de f., 2010.p. Derecho penal económico, Buenos Aires: Editorial B de f., 2010.

BHAGAT, Sanjai; BOLTON, Brian; ROMANO, Roberta. The promise and peril of corporate governance indices. In: OOSTWOUDER, Wilco (ed.). SCHENK, Hans (ed.). Corporate Governance: current issues and the financial crisis. Deventer: Kluwer, 2011.

BICUDO, Tatiana Viggiani. A globalização e as transformações do direito penal. In: Revista Brasileira de Ciências Criminais, São Paulo, ano 6, n. 23, p.97-109, julhosetembro, 1998.

BIEGELMAN, Martin T; BIEGELMAN, Daniel R. Building a world-class compliance program: best practices and strategies for success. Hoboken, N.J.: John Wiley \& Sons, 2008.

BIEGELMAN, Martin T; BIEGELMAN, Daniel R. Foreign corrupt practices act compliance guidebook: protecting your organization from bribery and corruption. Hoboken, N.J.: John Wiley \& Sons, 2010.

BLAIR, Margaret. Post-Enron reflections on comparative corporative governance. Georgetown Law and Economics. Research Paper No. 316663, 2002. Available at SSRN: http://ssrn.com/abstract=316663 or http://dx.doi.org/10.2139/ssrn.316663. Acesso em 15 de janeiro de 2016.

BLANCO CORDERO, Isidoro. Eficacia del sistema de prevención del blanqueo de capitales. Estudio del cumplimiento normativo (compliance) desde una perspectiva criminológica. Eguzkilore: Cuaderno del Instituto Vasco de Criminología, San Sebastian, n. 23, p.117-138, 2009.

BM\&FBOVESPA. Novo Mercado: Governança Corporativa. Disponível em: < http://www.bmfbovespa.com.br/ptbr/abmfbovespa/download/Folder_NovoMercado.pdf>. Acesso em 10 de fevereiro de 2015.

BOCK, Dennis. Compliance y deberes de vigilancia en la empresa. In: KUHLEN, Lothar (ed.). MONTIEL, Juan Pablo (ed.). ORTIZ DE URBINA GIMENO, Iñigo (ed.). Compliance y teoria del derecho penal. Madrid: Marcial Pons, 2013.

BORGERTH, Vania Maria da Costa. SOX: entendendo a Lei Sarbanes-Oxley - um caminho para a informação transparente. São Paulo: Cengage Learning, 2008. 
BOTTINI, Pierpaolo Cruz. Política de Combate à Lavagem de dinheiro. In: BADARÓ, Gustavo Henrique; BOTTINI, Pierpaolo Cruz. Lavagem de dinheiro: aspectos penais e processuais penais: comentários à Lei 9.613/1998, com as alterações da Lei 12.683/2012. 2.ed. rev.atual e ampl. São Paulo: Revista dos Tribunais, 2013.

BOTTINI, Pierpaolo Cruz; TAMASAUSKAS, Igor. A controversa responsabilidade objetiva na Lei 12.846/13. Revista do Advogado, São Paulo, v. 34, n. 125, p.125-130, dez. 2014.

BRAITHWAITE, John. Regulatory capitalism: how it works, ideas for making it work better. Massachusetts: Edward Elgar Publishing: 2008.

BRAITHWAITE, John. FISSE, Brent. Corporations, Crime and Accountability. Cambridge: Cambridge University Press, 1993.

BRAITHWAITE, John. The limits of economism in controlling harmful corporate conduct. Law and Society Review, 1981.p.481-504.

BRATTON, William W. Enron and the dark side of shareholder value. Tulane Law Review, $\quad$ n.76, 2002. Disponível em < http://scholarship.law.georgetown.edu/cgi/viewcontent.cgi?article $=1508 \&$ context $=$ facpub $>$ . Acesso em 29 de outubro de 2015.

BRODOWSKI, Dominik; ESPINOZA DE LOS MONTEROS DE LA PARRA, Manuel; TIEDEMANN, Klaus. Regulating Corporate Criminal Liability: an introduction. In: BRODOWSKI, Dominik; ESPINOZA DE LOS MONTEROS DE LA PARRA, Manuel; TIEDEMANN, Klaus (ed.). Regulating corporate criminal liability. Heidelberg: Springer, 2014.

BUCY, Pamela H. Carrots and Sticks: Post-Enron regulatory initiatives. Buffalo Criminal Law Review. vol.08. n.1, abril. 2004. p.277-322.

BURNS, Arthur F.; EDWARDS, Franklin R. U.S. Corporate Governance: what went wrong and can it be fixed?. Chicago, 2003. Disponível em: < https://www0.gsb.columbia.edu/mygsb/faculty/research/pubfiles/1661/U.S.\%20Corporate \%20Governance\%2010-05.pdf>. Acesso em 08 de fevereiro de 2016.

CANTERJI, Rafael Braude; TANGERINO, Davi de Paiva Costa. Estado, economia e direito penal: o direito penal tributário no liberalismo, no welfare state e no neoliberalismo. In: TANGERINO, Davi de Paiva Costa; GARCIA, Denise Nunes (Coord.). Direito penal tributário. São Paulo: Quartier Latin, 2007.

CARDOSO, Débora Motta. A extensão do compliance no direito penal análise crítica na perspectiva da lei de lavagem de dinheiro. São Paulo: Tese-USP, 2013.

CARVALHO, Antonio Gledson. Governança Corporativa no Brasil em perspectiva. In: SILVA, André Luiz Carvalhal da (org.); LEAL, Ricardo Pereira Câmara (org.). Governança Corporativa: Evidências Empíricas no Brasil. São Paulo: Editora Atlas, 2007. 
CARVAlHO, Érika Mendes. CARVAlHO, Gisele Mendes. Direito Penal de Risco e Responsabilidade Penal das Pessoas Jurídicas: a propósito da orientação jurisprudencial do Superior Tribunal de Justiça. In: PRADO, Luiz Regis; DOTTI, René Ariel (Coord.). Responsabilidade penal da pessoa jurídica: em defesa do princípio da imputação penal subjetiva. 4. ed. São Paulo: Revista dos Tribunais, 2013.

CESANO, Jose Daniel. La imputacion penal en el âmbito de la empresa y las estructuras omisivas: bases para su análisis. In: BERRUEZO, Rafael et al. Derecho penal económico, Buenos Aires: Editorial B de f., 2010.

CHAVES, Renato. O cidadão, as grandes corporações e a governança corporativa: cidadania combina com economia? In: FONTES FILHO, Joaquim Rubens (org.). LEAL, Ricardo Pereira Câmara (org.). O futuro da governança corporativa desafios e novas fronteiras. São Paulo: Saint Paul, 2013.

CLARK, Robert Charles. Corporate Governance changes in the wake of the SarbanesOxley Act: a morality tale for policymakers too. Harvard Law and Economics Discussion, n.525, 2005. Disponível em <http://papers.ssrn.com/sol3/papers. cfm?abstract_id=808244> . Acesso em 02 de fevereiro de 2016.

COCA VILA, Ivó. ¿Programas de cumplimiento como forma de autorregulación regulada? In: MONTANER FERNÁNDEZ, Raquel (coord.). Criminalidad de empresa y compliance. Prevención y reacciones corporativas. Barcelona: Atelier, 2013.

COFFEE JR, John C. No soul to damn: No body to kick: no unscandalized inquiry into the problem of corporate punishment. Michigan Law Review. Vol. 79, No. 3 (Jan. 1981), p. 386-459.

COFFEE JR, John C. The theory of corporate scandals: why the U.S. and Europe differ. Columbia Law and Economics, Working Paper n.274, mar. 2005.

COFFEE JR, John C. The future as history: the prospects for global convergence in corporate governance and its implications. 93, Northwestern University Law Review, 641. 1999.

COFFEE JR, John C. Understanding Enron: It's about the gatekeepers, stupid. 30 de julho de 2002. Columbia Law \& Economics Working Paper n.207. Disponível em: < http://www.law.columbia.edu/center_program/law_economics/wp_listing_1/wp_listing?ex clusive $=$ filemgr.download\&file_id $=6990 \&$ rtcontentdisposition $=$ filename\%3DWP207.pdf $>$ Acesso em 20 de abril de 2015.

COFFEE JR, John C. Law and the market: the impact of enforcement. Columbia Law and Economics, Working Paper n.304, mar. 2007.

COFFEE JR, John C. Corporate Crime and Punishment: a non-Chicago view of the economics of criminal sanctions. American Criminal Law Review, vol.17, 1980. 
COFFEE JR, John C. What caused Enron?. Columbia Law \& Economics Working Paper n. 214. 20 de janeiro de 2003 .

COFFEE JR, John C. Do norms matter? A cross-country evaluation. Disponível em < http://scholarship.law.upenn.edu/cgi/viewcontent.cgi?article=3334\&context=penn_law_re view>. Acesso em 11 de fevereiro de 2016.

COMPARATO, Fabio Konder. O Indispensável direito econômico. In: COMPARATO, Fabio Konder. Ensaios e pareceres de direito empresarial. Rio de Janeiro: Forense, 1978.

CONSELHO DE CONTROLE DE ATIVIDADES FINANCEIRAS. Relatório de Atividades 2015. Publicado em 07 de abril de 2016. Disponível em: $<$ http://www.coaf.fazenda.gov.br/noticias/coaf-publica-o-relatorio-de-atividades-2015>. Acesso em 30 de maio de 2016.

COSTA, Helena Regina Lobo da. O problema da definição da autoria em crimes empresariais. In: SILVEIRA, Renato de Mello Jorge (coord.). Crônicas franciscanas no Mensalão. São Paulo: Quartier Latin, 2014.

COSTA, Helena Regina Lobo. Exageros e incoerências da lei $n^{o}$. 12.683/12. In: SILVEIRA, Renato de Mello Jorge (coord.). Crônicas franciscanas no Mensalão. São Paulo: Quartier Latin, 2014.

COSTA, Helena Regina Lobo da; ARAÚJO, Marina Pinhão Coelho. Compliance e o julgamento da APn 470. Revista Brasileira de Ciências Criminais, São Paulo, v. 22, n. 106, p.215-230, jan./fev. 2014.

DELLA PORTA, Donatella. "Comparative Analysis: Case-oriented versus Variableoriented research". In DELLA PORTA, Donatella; KEATING, Michael (ed.), Approaches and methodologies in the social sciences: a pluralist perspective. Cambridge: Cambridge University Press, 2008.

DEMETRIO CRESPO, Eduardo. Fundamento da Responsabilidad en comisión por omisión de los directivos de las empresas. In: ARROYO ZAPATERO, Luis (dir.). LASCANO, Carlos (dir.). NIETO MARTIN, Adan. Derecho penal de la empresa: del derecho penal economico del Estado social al derecho penal de la empresa globalizado. Buenos Aires: Ediar, 2012.

DODD JR, Edwin Merrick. For whom corporate managers are trustees. 45, Harvard Law Review, 1932.

DOPICO GÓMEZ-ALLER, Jacobo. Posición de garante del compliance officer por infracción del "deber de control": una aproximación tópica. In: ARROYO ZAPATERO, Luis (dir.). NIETO MARTÍN, Adán (dir.). El derecho penal económico en la era compliance. Valência: Ed. Tirant lo Blanch, 2013. 
DOPICO GÓMEZ-ALLER, Jacobo. Presupuestos básicos de la respnsabilidad penal del Compliance Officer y otros garantes en la empresa. Actualidad jurídica Aranzadi, $N^{0} 843$, 2012, pág. 6.

DUARTE, Maria Carolina de Almeida. A globalização e os crimes de "lavagem de dinheiro": a utilização do sistema financeiro como porto seguro. Ciências Penais: Revista da Associação Brasileira de Professores de Ciências Penais, São Paulo, v. 1, n. 0, p.197225, jan./jun. 2004.

ELSTROM, Peter. How to hide \$3.8 billion in expenses. Bloomberg, 08 de julho de 2002. Disponível em: <http://www.bloomberg.com/news/articles/2002-07-07/how-to-hide-3-dot8-billion-in-expenses $>$. Acesso em 30 de maio de 2016.

ERHARD, Werner; JENSEN, Michael C.; ZAFFRON, Steve. Integrity: a positive model that incorporates the normative phenomena of morality, ethics and legality. Harvard Business School:23 de março de 2009. Disponível em <http:// http://papers.ssrn.com/sol3/papers.cfm?abstract_id=920625>. Acesso em 20 de novembro de 2015.

ESTELLITA, Heloisa; GRECO, Luís. Empresa, quadrilha (art. 288 do CP) e organização criminosa. Uma análise sob a luz do bem jurídico tutelado. Revista Brasileira de Ciências Criminais, São Paulo, v. 19, n. 91, p.393-409, jul./ago. 2011.

FAMA, Eugene F. Efficient capital markets: a review of theory and empirical work. The Journal of Finance, maio de 1970.

FERGUNSON, Charles H. O sequestro da América: como as corporações financeiras corromperam os Estados Unidos. Rio de Janeiro: Jorge Zahar Editor Ltda, 2012.

FERREIRA, Luciano Vaz. A construção do regime jurídico internacional anti-suborno e seus impactos no Brasil: como o Brasil pode controlar o suborno praticado por empresas transnacionais? Faculdade de Ciências Econômicas da UFRGS: Porto Alegre, 2015. Disponível em: $<$ https://www.lume.ufrgs.br/bitstream/handle/10183/109268/000950746.pdf?sequence=1>. Acesso em 15 de maio de 2016.

FRANCO, Alberto Silva. A crise financeira de 2008: cinco anos depois. Revista Brasileira de Ciências Criminais, São Paulo, v. 21, n. 103, p.131-157, jul./ago. 2013.

GODOI, Christiane Kleinübing (org). BANDEIRA-DE-MELLO, Rodrigo (org). SILVA, Anielson Barbosa da (org). Pesquisa qualitativa em estudos organizacionais paradigmas, estratégias e métodos. São Paulo: Saraiva, 2007.

GÓMEZ-JARA DÍEZ, Carlos. Cuestiones fundamentales de derecho penal económico: parte general y parte especial. Bogotá: Universidad Externado de Colombia, 2012. 
GÓMEZ-JARA DÍEZ, Carlos. Responsabilidad penal de los directivos de empresa en virtud de su dominio. In: SCHÜNEMANN, Bernd et al. Cuestiones actuales del sistema penal: crisis y desafios. Lima: Ara, 2008.

GÓMEZ MARTÌN, Victor. Compliance y derechos de los trabajadores. In: KUHLEN, Lothar (ed.). MONTIEL, Juan Pablo (ed.). ORTIZ DE URBINA GIMENO, Iñigo (ed.). Compliance y teoria del derecho penal. Madrid: Marcial Pons, 2013.

GONZÁLEZ DE LEÓN BERINI, Arturo. El criminal compliance en la reforma norteamericana de la Dodd-Frank Act. In: MONTANER FERNÁNDEZ, Raquel (coord.). Criminalidad de empresa y compliance. Prevención y reacciones corporativas. Barcelona: Atelier, 2013.

GONZÁLEZ FRANCO, José Ángel; SCHEMMEL Alexander; BLUMENBERG, Axel. La función del penalista en la confección, implementación y evaluación de los programas de cumplimiento. In: ARROYO ZAPATERO, Luis (dir.). NIETO MARTÍN, Adán (dir.). El derecho penal económico en la era compliance. Valência: Ed. Tirant lo Blanch, 2013.

GORDON, Jeffrey N. What Enron means for the management and control of the modern business corporations: some initial reflections. University of Chicago Law Review, Summer 2002.

GORGA, Érica. Arbitragem, governança corporativa e retrocesso no mercado de capitais brasileiro. In: FONTES FILHO, Joaquim Rubens (org). LEAL, Ricardo Pereira Câmara (org). O futuro da governança corporativa desafios e novas fronteiras. São Paulo: Saint Paul, 2013.

GRECO, Luís. ASSIS, Augusto. O que significa a Teoria do Domínio do fato para a criminalidade da empresa. In: GRECO, Luís, LEITE, Alaor, TEIXEIRA, Adriano, ASSIS, Augusto. Autoria como domínio do fato: estudos introdutórios sobre o concurso de pessoas do direito penal brasileiro. São Paulo: Marcial Pons, 2014.

GRECO, Luís. Domínio da organização e o chamado princípio da autorresponsabilidade. In: ZILIO, Jacson Luiz; BOZZA, Fábio da Silva (Org.). Estudos críticos sobre o sistema penal. Curitiba: LedZe, 2012.

GRECO, Luís. LEITE, Alaor. O que é e o que não é a teoria do domínio do fato. Sobre a distinção entre autor e partícipe no direito penal. In: GRECO, Luís, LEITE, Alaor, TEIXEIRA, Adriano, ASSIS, Augusto. Autoria como domínio do fato: estudos introdutórios sobre o concurso de pessoas do direito penal brasileiro. São Paulo: Marcial Pons, 2014.

GRECO FILHO, Vicente; RASSI, João Daniel. Decreto Estadual Anticorrupção contém inconstitucionalidade. Estadāo, São Paulo, 19 de fevereiro de 2014. Disponível em: < http://politica.estadao.com.br/blogs/fausto-macedo/decreto-estadual-anticorrupcao-conteminconstitucionalidade/>. Acesso em 24 de maio de 2016. 
HAMILTON, Stewart. FRANCIS, Inna. Enron Collapse. Harvard Business Review. Maio, 2003.

HAMILTON, Stewart. MICKLETHWAIT, Alicia. Greed and corporate failure: the lessons from recent disasters. New York: Palgrave Macmillan, 2006.

HEFENDEHL, Roland. Enron, WorldCom and the consequences: business criminal law between doctrinal requirements and the hopes of crime policy. Buffalo Criminal Law Review. Vol.8, n.1. Abril, 2004. pp.51-88.

HEMPHILL, Thomas A.; CULLARI, Francine. Corporate governance practices: $a$ proposed policy incentive regime to facilitate internal investigations and self-reporting of criminal activities. Journal of Business Ethics, vol.87, supplement 1, Abril de 2009. pp. 333-351.

HENRIQUES, Diana B.; EICHENWALD, Kurt. A fog over Enron, and the legal landscape. The New York Times, 27 de janeiro de 2002.

HOLMSTROM, Bengt; KAPLAN, Steven N. The State of U.S. Corporate Governance: what's right and what's wrong. Finance Working Paper, n.23, 2003. Disponível em < http://www.chicagobooth.edu/assests/stigler/185.pdf > . Acesso em 04 de fevereiro de 2016.

HOMER, Julia; KATZ, David M. WorldCom whistleblower Cynthia Cooper. CFO, $1^{\circ}$ de fevereiro de 2008. Disponível em: <http://ww2.cfo.com/human-capitalcareers/2008/02/worldcom-whistle-blower-cynthia-cooper/>. Acesso em 30 de maio de 2016.

HOUPT, Randell (ed.). The Foreign Corrupt Practices Act: a resource guide for businesses and individuals. New York: Nova Publishers, 2013.

IANNI, Octavio. Teorias da Globalização. Rio de Janeiro: Ed. Civilização Brasileira, 2004.

INSTITUTO BRASILEIRO DE GOVERNANÇA CORPORATIVA. Código das melhores práticas de governança corporativa. 4.ed. São Paulo: IBGC, 2009.

JAPIASSU, Carlos Eduardo Adriano; PEREIRA, Daniel Queiroz. Direito Penal econômico e tributário: uma análise histórica e comparada. In: SOUZA, Artur de Brito Gueiros (org). Inovações no Direito Penal Econômico: Contribuições criminológicas, político-criminais e dogmáticas. Brasília: Escola Superior do Ministério Público da União, 2011.

KRUGMAN, Paul. A crise de 2008 e a economia da depressão. Rio de Janeiro: Elsevier, 2009.

KÜHL, Kristian. Direito penal fragmentário e subsidiário. In: OLIVEIRA, William Terra de; LEITE, NETO, Pedro Ferreira; ESSADO, Tiago Cintra; SAAD-DINIZ, Eduardo 
(orgs.). Direito penal econômico: estudos em homenagem aos 75 anos do Professor Klaus Tiedemann. São Paulo: LiberArs, 2013.

KUHLEN, Lothar. Cuestiones fundamentales de compliance y derecho penal. In: KUHLEN, Lothar (ed.). MONTIEL, Juan Pablo (ed.). ORTIZ DE URBINA GIMENO, Iñigo (ed.). Compliance y teoria del derecho penal. Madrid: Marcial Pons, 2013.

LAUFER, William S. Corporate Bodies and Guilty Minds: The failure of Corporate Criminal Liability. Chicago: University of Chicago Press, 2006.

LAUFER, William S. Where is the moral indignation over corporate crime? In: BRODOWSKI, Dominik; DE LA PARRA, Manuel Espinoza de los Monteros; TIEDEMANN, Klaus (ed.). Regulating corporate criminal liability. Heidelberg: Springer, 2014.

LAUFER, William S. O compliance game. In: SAAD-DINIZ, Eduardo (org.); BRODOWSKI, Dominik (org.); SÁ, Ana Luiza de (org.). Regulação do abuso no âmbito corporativo: o papel do direito penal na crise financeira. São Paulo: Editora LiberArs, 2015.

LAUFER, William S. GEIS, Gilbert. Corporate crime and a new brand of cooperative regulation. Disponível em http: < http://www.defensesociale.org/02/15.pdf $>$. Acesso em 15 de novembro de 2015.

LASCURAÍN, Juan Antonio. Compliance, debido control y unos refrescos. In: ARROYO ZAPATERO, Luis (dir.). NIETO MARTÍN, Adán (dir.). El derecho penal económico en la era compliance. Valência: Ed. Tirant lo Blanch, 2013.

LAVELLE, Louis. How governance rules failed at Enron. Bloomberg Business, 20 de janeiro de 2002.

LEWIS, Michael. A jogada do século. 2.ed. Rio de Janeiro: Editora Best Seller, 2016.

LIMA, Iran Siqueira (coord.). LIMA, Gerlando Augusto Sampaio Franco de (coord.). PIMENTEL, Renê Coppe (coord.). Curso de Mercado Financeiro: tópicos especiais. São Paulo: Atlas, 2006.

LOPES, Marcelo Rodrigo. Governança Corporativa e redução de assimetrias de informação. Faculdade de Direito, Universidade de São Paulo, São Paulo, 2015.

LYKE, Bob; JICKLING, Mark. WorldCom: the accounting scandal. CRS Report for Congress. Agosto, 2002.

MACHADO, Maíra Rocha. Internacionalização do direito penal. Sāo Paulo: Edesp, 2004.

MACHADO FILHO, Cláudio Pinheiro. Responsabilidade social e governança o debate e as implicações: responsabilidade social, instituições, governança e reputação. São Paulo: Pioneira Thomson Learning, 2006. 
MAGLIANO, Raymundo. Mercado de Capitais, Poder Econômico e Regulação. In: FERRAZ JUNIOR, Tercio Sampaio (org). SALOMÃO FILHO, Calixto (org). NUSDEO, Fábio (org). Poder econômico direito, pobreza, violência, corrupção. Barueri, SP, Manole, 2009.

MARMER, Ronald L. WEISSMAN, Andrew. Think of the Corporate Office as a potential crime scene? Disponível em: < https://jenner.com/system/assets/publications/7655/original/NYLJ_Corporate_Office_as_Potential_ Crime_Scene_Marmer_Weissman.pdf?1323121835>. Acesso em 10 de abril de 2015.

MAROTO CALATAYUD, Manuel. Liberalismo vs. Neocorporativismo: los discursos de la autorregulación como discursos legitimantes. In: ARROYO JIMÉNEZ, Luis (dir.); NIETO MARTÍN, Adán (dir.). Autorregulación y sanciones. Valladolid: Lex Nova, 2008.

MARTIN, Jay; McCONNELL, Ryan D.; SIMON, Charlotte A. Plan now or pay later: the role of compliance in criminal cases. Houston: Forthcoming UH International Law Journal, 2011.

MASCHMANN, Frank. Compliance y derechos del trabajador. In: KUHLEN, Lothar (ed.). MONTIEL, Juan Pablo (ed.). ORTIZ DE URBINA GIMENO, Iñigo (ed.). Compliance y teoria del derecho penal. Madrid: Marcial Pons, 2013.

MATTEN, Dirk; CRANE, Andrew; CHAPPLE, Wendy. Behind the mask: revealing the true face of corporate citizenship. Journal of Business Ethics, vol.45, junho de 2003.

MATTOS, Eduardo da Silva. O que a crise do subprime ensinou ao Direito? Tese (Doutorado em Direito Comercial) - Faculdade de Direito, Universidade de São Paulo, São Paulo, 2014.

MATUS ACUÑA, Jean Pierre. La certificación de los programas de cumplimiento. In: ARROYO ZAPATERO, Luis (dir.). NIETO MARTÍN, Adán (dir.). El derecho penal económico en la era compliance. Valência: Ed. Tirant lo Blanch, 2013.

MCBARNET, Doreen. When Compliance is not the Solution but the Problem: From Changes in Law to Changes in Attitude. Working Paper n.18, 2001. Disponível em $<\mathrm{http}: / /$ https://digitalcollections.anu.edu.au/bitstream/1885/41635/2/WP18.pdf $>$. Acesso em 16 de novembro de 2015.

MONTIEL, Juan Pablo. Autolimpeza empresarial: compliance programs, investigaciones internas y neutralización de riesgos penales. In: KUHLEN, Lothar (ed.). MONTIEL, Juan Pablo (ed.). ORTIZ DE URBINA GIMENO, Iñigo (ed.). Compliance y teoria del derecho penal. Madrid: Marcial Pons, 2013.

MOOSMAYER, Klaus. Investigaciones internas: una introducción a sus problemas esenciales. In: ARROYO ZAPATERO, Luis; NIETO MARTÍN, Adán (org) El derecho penal económico en la era compliance. Valencia: Tirant lo Blanch, 2013. 
MORALES ROMERO, Marta Muñoz de. Programas de cumplimiento "efectivos" en la experiência comparada. In: ARROYO ZAPATERO, Luis; NIETO MARTÍN, Adán (org) El derecho penal económico en la era compliance. Valencia: Tirant lo Blanch, 2013.

MORGENSON, Gretchen. The Markets: Stocks \& Bonds; Worries of more Enrons to come give stock prices a pounding. The New York Times, 30 de janeiro de 2002.

MOSBERG, Dennis; ROMAR, Edward. WorldCom Case Study. Disponível em $<$ http://www.prmia.org/sites/default/files/references/WorldCom_Case_Study_April_2009. pdf $>$. Acesso em 30 de maio de 2016.

NAVARRO DOLMESTCH, Roberto. Reconfiguración del sistema de fuentes del derecho penal y amenaza de crisis del principio de legalidad: la incorporación del derecho internacional convencional y el fenómeno de la globalización. In: FARALDO CABANA, Patricia. Nuevos retos del derecho penal en la era de la globalización. Valencia: Tirant lo Blanch, 2004.

NIETO MARTÍN, Adán. Regulatory Capitalism y cumplimiento normativo. In: ARROYO ZAPATERO, Luis; NIETO MARTÍN, Adán (coord). El derecho penal em la era compliance. Valencia: Tirant lo Blanch, 2013.

NIETO MARTÍN, Adán. La privatización de la lucha contra la corrupción. In: ARROYO ZAPATERO, Luis (dir.). NIETO MARTÍN, Adán (dir.). El derecho penal económico en la era compliance. Valência: Ed. Tirant lo Blanch, 2013.

NIETO MARTÍN, Adán. Problemas fundamentales del cumplimiento normativo en el derecho penal. In: KUHLEN, Lothar (ed.). MONTIEL, Juan Pablo (ed.). ORTIZ DE URBINA GIMENO, Iñigo (ed.). Compliance y teoria del derecho penal. Madrid: Marcial Pons, 2013.

NIETO MARTÍN, Adán. Responsabilidad social, gobierno corporativo y autorregulación: sus influencias en el derecho penal de la empresa. Polít. crim., N 5, 2008, A3-5, pp.1-18.

NIETO MARTÍN, Adán. El programa político-criminal del corporate goverment: derecho penal de la empresa y gobierno corporativo. Revista Aranzadi de derecho y proceso penal, Navarra, n. 11, p.259-281, 2004.

OCDE: Good Practice Guidance on Internal Controls, Ethics and Compliance, 2010. Disponível em: <http://www.oecd.org/daf/anti-bribery/44884389.pdf>. Acesso em 08 de fevereiro de 2016.

OCDE: Convenção das Nações Unidas contra a Corrupção, 2005. Disponível em: $<$ https://www.unodc.org/lpo-brazil/pt/corrupcao/convencao.html $>$. Acesso em 16 de abril de 2016.

OCDE: Building an Institutional Framework for Regulatory Impact Analysis (RIA): Guidance for policy makers, 2008. Disponível em: < http://www.oecd.org/gov/regulatorypolicy/40984990.pdf>. Acesso em 25 de abril de 2016. 
OCDE: Reference checklist for regulatory decision-making. Disponível em: < https://www.oecd.org/gov/regulatory-policy/35220214.pdf $>$. Acesso em 25 de abril de 2016 .

PADGET, Tim. The rise and fall of Bernie Ebbers. Revista Time, 05 de maio de 2002. Disponível em: < http://content.time.com/time/magazine/article/0,9171,235450,00.html>. Acesso em 30 de maio de 2016.

PARKER, Christine. The compliance trap: the moral message in responsive regulatory enforcement. Disponível em $<\mathrm{http}: / /$ http://papers.ssrn.com/sol3/papers.cfm?abstract_id=927559>. Acesso em 10 de dezembro de 2015.

PARKER, Christine. Is there a reliable way to evaluate organisational compliance programs? Disponível em: $<$ http://www.aic.gov.au/media_library/conferences/regulation/parker.pdf $>$. Acesso em 15 de abril de 2015.

PARKER, Christine. NIELSEN, Vibeke Lehmann. Corporate Compliance Systems: could they make any difference? Administration and Society n.41, December, 2008.

PARKER, Christine. The open corporation: effective self-regulation and democracy. Nova York: Cambridge University Press, 2002.

PELLEGRINI, Marcelo. Regulação financeira falha criou mecanismos da crise de 2008. USP Online Destaque, 27 de outubro de 2011. Disponível em: $<$ http://www5.usp.br/1999/regulacao-financeira-falha-criou-mecanismos-da-crise-de2008/>. Acesso em 10 de fevereiro de 2016.

PIMENTEL, Manoel Pedro. Direito Penal Econômico. São Paulo: Revista dos Tribunais, 1973.

PITT, Harvey. GROSKAUFMANIS, Karl. When bad things happen to good companies: a crisis management primer. Cardozo Law Review. 15, 951, Jan. 1, 1994.

PLESSIS, Jean Jacques du. HARGOVAN, Anil. BAGARIC, Mirko. HARRIS, Jason. Principles of contemporary corporate governance. Australia, Cambrigde University Press, 2015.

POSNER, Richard A. Teorias da Regulação Econômica. In: MATTOS, Paulo (coord). PRADO, Mariana Mota (org). ROCHA, Jean Paul Cabral Veiga da (org). COUTINHO, Diogo R. (org). OLIVA, Rafael (org). Regulação Econômica e Democracia: o debate norte-americano. São Paulo: Ed. 34, 2004.

PRADO, Luiz Regis. Responsabilidade Penal da Pessoa Jurídica: Fundamentos e Implicações. In: PRADO, Luiz Regis; DOTTI, René Ariel (Coord.). Responsabilidade 
penal da pessoa jurídica: em defesa do princípio da imputação penal subjetiva. 4. ed. São Paulo: Revista dos Tribunais, 2013.

PRADO, Roberta Nioac; VILELA, Renato. Teoria e Prática na governança corporativa: distanciamento das dimensões em função do formalismo. In: FONTES FILHO, Joaquim Rubens (org). LEAL, Ricardo Pereira Câmara (org). O futuro da governança corporativa desafios e novas fronteiras. São Paulo: Saint Paul, 2013.

PRITTWITZ, Cornelius. La posición jurídica (en especial, posición de garante) de los compliance officers. In: KUHLEN, Lothar (ed.). MONTIEL, Juan Pablo (ed.). ORTIZ DE URBINA GIMENO, Iñigo (ed.). Compliance y teoria del derecho penal. Madrid: Marcial Pons, 2013.

PRITTWITZ, Cornelius. O Direito Penal em uma encruzilhada: abolição, diversificação, retornar à razão ou entrar em razão? Revista de Ciências Jurídicas - UEM, vol. 7, nº.01, jan/jun. 2009. Disponível em: < http://www.periodicos.uem.br/ojs/index.php/RevCiencJurid/article/view/11064>. Acesso em 13 de maio de 2016.

RAGUÉS I VALLÈS, Ramon. Whistleblowing: una aproximación desde del derecho penal. Madrid: Marcial Pons, 2013.

REALE JUNIOR, Miguel. A Responsabilidade Penal da Pessoa Jurídica. In: PRADO, Luiz Regis; DOTTI, René Ariel (Coord.). Responsabilidade penal da pessoa jurídica: em defesa do princípio da imputação penal subjetiva. 4. ed. São Paulo: Revista dos Tribunais, 2013.

REISINGER, Sue. Half-baked justice? Corporate prosecutions are all over the map. Janeiro, 2011. Disponível em <http:/www.hilderlaw.com/Related-News/Half-BakedJustice-Corporate-Prosecutions-Are-All-Over-the-Map.shtml>. Acesso em 02 de fevereiro de 2016.

RIBEIRO, Ivan César. Regulação financeira, poder no mercado e crise financeira. Tese (Doutorado em Direito Comercial) - Faculdade de Direito, Universidade de São Paulo, São Paulo, 2012. Disponível em: <http://www.teses.usp.br/teses/disponiveis/2/2132/tde30072013-231616/>. Acesso em 20 de abril de 2016.

ROBLES PLANAS, Ricardo. El responsable de cumplimiento ("compliance officer") ante el derecho penal. In: SILVA SÁNCHEZ, Jesús-María (dir.). MONTANER FERNÁNDEZ, Raquel (coord.). Criminalidad de empresa y compliance. Barcelona: Atelier Libros, 2013.

RODRIGUEZ ESTEVEZ, Juan María. Legalidad y Eficiencia en Materia Penal Empresaria. In: BERRUEZO, Rafael et al. Derecho penal económico, Buenos Aires: Editorial B de f., 2010. 
RODRIGUEZ, Victor Gabriel. Lendas e equívocos do crime de lavagem de dinheiro. In: SILVEIRA, Renato de Mello Jorge (coord.). Crônicas franciscanas no Mensalão. São Paulo: Quartier Latin, 2014.

ROSE, Cecily. International anti-corruption norms: their creation and influence on domestic legal systems. Reino Unido: Oxford University Press, 2015.

ROSEN, Robert Eli. Risk Management and Corporate Governance: The Case of Enron. 35 Connecticut Law Rev. 1157-1184, 2003.

ROTSCH, Thomas. Criminal compliance. InDret Revista para el análisis del derecho. Barcelona, jan., 2012.

ROXIN, Claus; BUSATO, Paulo Cesar (Trad.). O domínio da organização como forma independente de autoria mediata. Revista justiça e sistema criminal: modernas tendências do sistema criminal, Curitiba, v. 3, n. 5, p.7-22, jul./dez. 2011.

ROXIN, Imme; LEITE, Alaor; TEIXEIRA, Adriano (Trad.). Responsabilidade do administrador de empresa por omissão imprópria. Revista Brasileira de Ciências Criminais, São Paulo, v. 23, n. 112, p.61-77, jan./fev. 2015.

ROYSEN, Joyce. Histórico da criminalidade econômica. Revista Brasileira de Ciências Criminais, São Paulo, v. 11, 42 Esp, p.192-213, jan./mar. 2003.

SAAD-DINIZ, Eduardo. A criminalidade empresarial e a cultura de compliance. Revista Eletrônica de Direito Penal AIDP-GB, v. 2, 2014.

SAAD-DINIZ, Eduardo. Escândalos de corrupção corporativa: filme de terror sem fim?. Boletim IBCCRIM, São Paulo, v. 23, n. 274, p.11-12, set. 2015.

SAAD-DINIZ, Eduardo. Fronteras del normativismo: a ejemplo de las funciones de la información en los programas de criminal compliance. Revista da Faculdade de Direito, v. 108, p. 415-441, 2013.

SAAD-DINIZ, Eduardo. Regulação privada: há ainda alternativas para a prevenção à corrupção e proteção de direitos humanos no âmbito corporativo? In: SAAD-DINIZ, Eduardo (org.); BRODOWSKI, Dominik (org.); SÁ, Ana Luiza de (org.). Regulação do abuso no âmbito corporativo: o papel do direito penal na crise financeira. São Paulo: Editora LiberArs, 2015.

SAAD-DINIZ, Eduardo. Os danos sociais da lavagem de dinheiro. In: SILVEIRA, Renato de Mello Jorge (coord.). Crônicas franciscanas no Mensalão. São Paulo: Quartier Latin, 2014.

SAAVEDRA, Giovani Agostini. Compliance na nova lei de lavagem de dinheiro. Revista Síntese de direito penal e processual penal, Porto Alegre, v. 13, n. 75, p.22-30, ago./set. 2012 . 
SAAVEDRA, Giovani Agostini. Compliance e prevenção na Lei de lavagem de dinheiro: sobre os reflexos da Lei n. 12.683/2012 no mercado de seguros. Revista de Estudos Criminais, Porto Alegre, v. 12, n. 54, p.165-180, jul./set. 2014.

SALAMA, Bruno Meyerhof. Direito e Economia. In: José Rodrigo Rodriguez. (Org.). Fragmentos para um Dicionário Crítico de Direito e Desenvolvimento. 2. ed.São Paulo: Saraiva, 2011, v. 1, p. 101-116.

SALGADO, Lucia Helena (org). FIUZA, Eduardo (org). Marcos regulatórios no Brasil revendo o papel do Estado após a crise financeira. Rio de Janeiro: Ipea, 2010.

SALOMÃO FILHO, Calixto. Desigualdade econômica e insuficiência regulatória. In: FERRAZ JUNIOR, Tercio Sampaio (org). SALOMÃO FILHO, Calixto (org). NUSDEO, Fábio (org). Poder econômico direito, pobreza, violência, corrupção. Barueri, SP, Manole, 2009.

SALVADOR NETTO, Alamiro Velludo. Lavagem de dinheiro e seu protagonismo no direito penal. In: SILVEIRA, Renato de Mello Jorge (coord.). Crônicas franciscanas no Mensalão. São Paulo: Quartier Latin, 2014.

SAMPAIO, Diego Barreiros Dutra. Speak now or forever hold your peace: an empirical investigation of whistleblowing in Brazilian organizations. São Paulo: Escola Brasileira de Administração Pública e de Empresas, Centro de Formação Acadêmica e Pesquisa, 2012.

SARCEDO, Leandro. Compliance e Responsabilidade Penal da Pessoa Jurídica: Construção de um novo modelo de imputação, baseado na culpabilidade corporativa. Faculdade de Direito, Universidade de São Paulo, São Paulo, 2014.

SCAFF, Fernando Facury; SILVEIRA, Renato de Mello Jorge. Lei anticorrupção é substancialmente de caráter penal. Consultor Jurídico (São Paulo. Online), v. 1, p. 1, 2014.

SCARROW, Devin. Understanding the Sarbanes-Oxley Act and its impact. Harvard Business Review. Setembro, 2009.

SCHÜNEMANN, Bernd. Del derecho penal de la clase baja al derecho penal de la clase alta: un cambio de paradigma como exigencia moral. In: SCHÜNEMANN, Bernd. Temas actuales y permanentes del derecho penal después del milenio. Madrid: Tecnos, 2002.

SCHÜNEMANN, Bernd. A chamada "crise financeira" - falha sistêmica ou criminalidade globalmente organizada. In: GRECO, Luís (Coord.); SCHÜNEMANN, Bernd. Estudos de direito penal, direito processual penal e filosofia do direito. São Paulo: Marcial Pons, 2013.

SCHÜNEMANN, Bernd. Do templo ao mercado? Como a justiça penal aparentemente transforma a teoria econômica do direito em prática, governo em governança e soberania em cooperação. In: GRECO, Luís (Coord.); SCHÜNEMANN, Bernd. Estudos de direito penal, direito processual penal e filosofia do direito. São Paulo: Marcial Pons, 2013. 
SCHÜNEMANN, Bernd. Responsabilidad penal en el marco de la empresa. Dificuldades relativas a la individualización de la imputación. In: Anuario de Derecho Penal y Ciencias Penales. Madrid, Volume LV, 2002, pp. 9-38.

SCHÜNEMANN, Bernd. A chamada "crise financeira" - falha sistêmica ou criminalidade globalmente organizada? In: GRECO, Luís (Coord.); SCHÜNEMANN, Bernd. Estudos de direito penal, direito processual penal e filosofia do direito. São Paulo: Marcial Pons, 2013.

SCHÜNEMANN, Bernd. Do templo ao mercado? Como a justiça penal aparentemente transforma a teoria econômica do direito em prática, governo em governança e soberania em cooperação. In: GRECO, Luís (Coord.); SCHÜNEMANN, Bernd. Estudos de direito penal, direito processual penal e filosofia do direito. São Paulo: Marcial Pons, 2013.

SHECAIRA, Sérgio Salomão. A responsabilidade penal da pessoa jurídica e nossa recente legislação. In: GOMES, Luiz Flávio. Responsabilidade penal da pessoa jurídica e medidas provisórias e direito penal. São Paulo: Revista dos Tribunais, 2001.

SHECAIRA, Sérgio Salomão. Responsabilidade Penal da Pessoa Jurídica. 3.ed. Rio de Janeiro: Elsevier, 2011.

SHECAIRA, Sérgio Salomão. Responsabilidade penal das pessoas jurídicas. In: OLIVEIRA, William Terra de; LEITE, NETO, Pedro Ferreira; ESSADO, Tiago Cintra; SAAD-DINIZ, Eduardo (orgs.). Direito penal econômico: estudos em homenagem aos 75 anos do Professor Klaus Tiedemann. São Paulo: LiberArs, 2013.

SHERMAN, Lawrence et al. Preventing crime: what works, what doesn't, what's promising. National Institute of Justice, 1998.

SICA, Leonardo. Tutela penal da ordem econômica no direito brasileiro: comparação entre as leis n.8137/90 e 8884/94. In: VILARDI, Celso Sanchez (org). PEREIRA, Flávia Rahal Bresser (org). DIAS NETO, Theodomiro. Direito Penal Econômico: Análise Contemporânea. São Paulo: Saraiva, 2009.

SIEBER, Ulrich. ENGELHART, Marc. Compliance Programs for the prevention of economic crimes: an empirical survey of german companies. Berlim: Duncker \& Humblot, 2014.

SIEBER, Ulrich. Programas de compliance em direito penal empresarial: um novo conceito para o controle da criminalidade econômica. In: OLIVEIRA, William Terra de; LEITE, NETO, Pedro Ferreira; ESSADO, Tiago Cintra; SAAD-DINIZ, Eduardo (orgs.). Direito penal econômico: estudos em homenagem aos 75 anos do Professor Klaus Tiedemann. São Paulo: LiberArs, 2013.

SILVA SÁNCHEZ, Jesús-María. A expansão do direito penal: aspectos da política criminal nas sociedades pós-industriais. 3. ed. São Paulo: Revista dos Tribunais, 2013. 
SILVA SÁNCHEZ, Jesús-María. El derecho penal ante la globalización y la integración supranacional. Revista Brasileira de Ciências Criminais, São Paulo, v. 6, n. 24, p.65-78, out./dez. 1998.

SILVA SÀNCHEZ, Jesús-María. Responsabilidad penal de las empresas y de sus organos en derecho español. In: PRADO, Luiz Regis; DOTTI, René Ariel (Coord.). Responsabilidade penal da pessoa jurídica: em defesa do princípio da imputação penal subjetiva. 4. ed. São Paulo: Revista dos Tribunais, 2013.

SILVA SÁNCHEZ, Jesús-María. Fundamentos del derecho penal de la empresa. Montevideo: B. de F., 2013.

SILVA SÁNCHEZ, Jesús-María. Deberes de vigilancia y compliance empresarial. In: KUHLEN, Lothar (ed.). MONTIEL, Juan Pablo (ed.). ORTIZ DE URBINA GIMENO, Iñigo (ed.). Compliance y teoria del derecho penal. Madrid: Marcial Pons, 2013.

SILVA SÀNCHEZ, Jesús-María. Responsabilidades individuales em estructuras de empresa: la influencia de sesgos cognitivos y dinâmicas de grupo. In: SILVA SÁNCHEZ, Jesús-María (dir.). MONTANER FERNÁNDEZ, Raquel (coord.). Criminalidad de empresa y compliance. Barcelona: Atelier Libros, 2013.

SILVA, André Luiz Carvalhal da; LEAL, Ricardo Pereira Câmara. Índice de Governança Corporativa, Valor e Desempenho da Firma no Brasil. In: SILVA, André Luiz Carvalhal da (org); LEAL, Ricardo Pereira Câmara (org). Governança Corporativa: Evidências Empíricas no Brasil. São Paulo: Editora Atlas, 2007.

SILVA, José Afonso. Curso de Direito Constitucional Positivo. 32 ed. ver. atual. São Paulo: Editora Malheiros, 2009.

SILVEIRA, Alexandre Di Miceli da. Governança corporativa: desempenho e valor da empresa no Brasil. São Paulo, Saint Paul, 2009.

SILVEIRA, Alexandre Di Miceli da. Governança corporativa no Brasil e no mundo teoria e prática. Rio de Janeiro: Editora Campus, 2010.

SILVEIRA, Renato de Mello Jorge. Direito penal econômico como direito penal de perigo. São Paulo: Revista dos Tribunais, 2006.

SILVEIRA, Renato de Mello Jorge. A atual percepção sobre o fenômeno da corrupção: questão penal, econômica ou de direitos humanos? Revista do Advogado, São Paulo, v. 34, n. 125, p.131-137, dez. 2014.

SILVEIRA, Renato de Mello Jorge. Ponderações sobre o compliance criminal. Valor Econômico, 01 de julho de 2014. Disponível em < http://www.valor.com.br/legislacao/3599626/ponderacoes-sobre-o-compliancecriminal\#ixzz36DitFFRo>. Acesso em 05 de fevereiro de 2016. 
SILVEIRA, Renato de Mello Jorge. Considerações penais sobre o acordo de leniência na realidade antitruste. In: PASCHOAL, Janaína Conceição; SILVEIRA, Renato de Mello Jorge (Coord.). Livro homenagem a Miguel Reale Júnior. Rio de Janeiro: G/Z, 2014.

SILVEIRA, Renato de Mello Jorge. Organização e Associação Criminosa nos crimes econômicos: Realidade típica ou contradição em termos? In: OLIVEIRA, William Terra de; LEITE, NETO, Pedro Ferreira; ESSADO, Tiago Cintra; SAAD-DINIZ, Eduardo (orgs.). Direito penal econômico: estudos em homenagem aos 75 anos do Professor Klaus Tiedemann. São Paulo: LiberArs, 2013.

SILVEIRA, Renato de Mello Jorge. Risco Bancário e Direito Penal Econômico. In: SILVEIRA, Renato de Mello Jorge (coord.). Crônicas franciscanas no Mensalão. São Paulo: Quartier Latin, 2014.

SILVEIRA, Renato de Mello Jorge; NETTO, Alamiro Velludo Salvador. Sarbanes-Oxleyact e os vícios do direito penal globalizado. Revista Ultima Ratio, Rio de Janeiro, v. 1, n. 0, p.193-210, 2006.

SILVEIRA, Renato de Mello Jorge; SAAD-DINIZ, Eduardo. Compliance, Direito Penal e Lei Anticorrupção. São Paulo: Saraiva, 2015.

SILVEIRA, Renato de Mello Jorge; SAAD-DINIZ, Eduardo. Criminal compliance: os limites da cooperação normativa quanto à lavagem de dinheiro. Revista peruana de ciencias penales, Lima, n. 25, p.591-626, 2013.

SOUZA, Luciano Anderson de. Lei Anticorrupção: avanços e desafios. Boletim IBCCRIM, São Paulo, v. 22, n. 256, p.4-5, mar. 2014.

SOUZA, Luciano Anderson de. Lei Anticorrupção: balanço de um semestre de muitos desacertos. Boletim IBCCRIM, São Paulo, v. 22, n. 260, p.11-12, jul. 2014.

STEINBERG, Richard M. Governance, Risk Management and Compliance: it can't happen to us - avoiding corporate disaster while driving success. New Jersey: John Wiley \& Sons, 2011.

STOUT, Lynn. The Shareholder Value Myth: how putting shareholders first harms investors, corporations and the public. São Francisco, EUA: Berrett-Kochler Publishers, 2012 .

STOUT, Lynn. Cultivating Conscience: how good laws make good people. Princeton University Press, 2010.

SWANBORN, Peter. Case Study Research: what, why and when. London: SAGE Publications Inc, 2010.

TANGERINO, Davi de Paiva Costa. Culpabilidade e responsabilidade penal da pessoa jurídica. Revista Brasileira de Ciências Criminais, São Paulo, v. 18, n. 86, p.36-60, set./out. 2010. 
TAVARES, Juarez. Alguns aspectos da estrutura dos crimes omissivos. Revista Brasileira de Ciências Criminais, São Paulo, v. 4, n. 15, p.125-157, jul./set. 1996.

TERRADILlOS BASOCO, Juan Maria. Cuestiones actuales de derecho penal económico $y$ de la empresa. Lima: Ara, 2010.

TERRADILLOS BASOCO, Juan Maria. Concepto y método del derecho penal económico. In: ARROYO ZAPATERO, Luis (dir.). LASCANO, Carlos (dir.). NIETO MARTIN, Adan. Derecho penal de la empresa: del derecho penal economico del Estado social al derecho penal de la empresa globalizado. Buenos Aires: Ediar, 2012.

TEUBNER, Gunther. Globalización y Constitucionalismo Social: Alternativas a la Teoría Constitucional centrada en el Estado. Anuario de la Facultad de Derecho de la Universidad Autonoma de Madrid. n.9, 2005.

TEUBNER, Gunther. Self-constitutionalizing TNCs? On the linkage of "private" and "public" corporate codes of conduct. Indiana Journal of Global Legal Studies, vol.18, 2011.

TEUBNER, Gunther. The corporate codes of multinationals: company constitutions beyond corporate governance and co-determination. Disponível em: < https://www.jura.uni-frankfurt.de/42852611/CorporateCodes_eng.pdf $>$. Acesso em 15 de março de 2016.

TEUBNER, Gunther. Breaking frames: economic globalisation and the emergence of lex mercatoria. Disponível em: $<\mathrm{http}: / /$ papers.ssrn.com/sol3/papers.cfm?abstract_id=893143>. Acesso em 13 de abril de 2016.

TIEDEMANN, Klaus. Corporate Criminal Liability as a Third Track. In: BRODOWSKI, Dominik; ESPINOZA DE LOS MONTEROS DE LA PARRA, Manuel; TIEDEMANN, Klaus (ed.). Regulating corporate criminal liability. Heidelberg: Springer, 2014.

TIEDEMANN, Klaus. Derecho penal económico: introducción y parte general. San José: Grijley, 2009.

TIEDEMANN, Klaus. El concepto de derecho económico, de derecho penal económico y de delito económico. Cuadernos de política criminal, Madrid, n. 28, p.65-74, 1986.

TIEDEMANN, Klaus. La criminalidad económica como objeto de investigación. Cuadernos de política criminal, Madrid, n. 19, p.171-183, 1983.

TIEDEMANN, Klaus. La criminalité socio-économique: aspects internationaux et de droit comparé. Revue de Science Criminelle et de Droit Pénal Comparé, Paris, n. 4, p.749-763, out./dez. 1974.

TIEDEMANN, Klaus. Les tâches de la recherche et de la réforme dans le domaine de la criminalité économique sur le plan international. Revue de Science Criminelle et de Droit Pénal Comparé, Paris, n. 3, p.451-470, jul./set. 1985. 
TIEDEMANN, Klaus. Manual de Derecho Penal Económico: parte general y especial. Valencia: Ed. Tirant lo Blanch, 2010.

TIEDEMANN, Klaus. Poder Económico y Delito. Barcelona: Ed. Ariel, 1985.

UNITED KINGDOM MINISTRY OF JUSTICE. The Bribery Act 2010: Guidance about procedures which relevant commercial organisations can put into place to prevent persons associated with them from bribing. Março de 2011. Disponivel em: $<$ https://www.justice.gov.uk/downloads/legislation/bribery-act-2010-guidance.pdf $>$. Acesso em 13 de maio de 2016.

U.S. DEPARTMENT OF JUSTICE: Individual Accountability for Corporate Wrongdoing. Washington D.C., 09 de setembro de 2015. Disponível em: < https://www.justice.gov/dag/file/769036/download>. Acesso em 16 de maio de 2015.

U.S. DEPARTMENT OF JUSTICE: Justice Department recovers over \$3.5 billion from False Claims Act cases in Fiscal Year 2015. Washington D.C, 03 de dezembro de 2015. Disponível em: < https://www.justice.gov/opa/pr/justice-department-recovers-over-35billion-false-claims-act-cases-fiscal-year-2015>. Acesso em 16 de maio de 2015.

U.S. DEPARTMENT OF JUSTICE: FCPA Guide: a resource guide to the U.S. Foreign Corrupt Practices Act. Washington D.C., 14 de novembro de 2012. Disponível em: $<$ https://www.justice.gov/criminal-fraud/fcpa-guidance $>$. Acesso em 20 de maio de 2016.

VOGEL, Joachim. Derecho penal y globalización. Anuario de la Facultad de Derecho de la Universidad Autonoma de Madrid. n.9, 2005.

VOGEL, Joachim. Rethinking Corporate Criminal Liability. In: BRODOWSKI, Dominik; DE LA PARRA, Manuel Espinoza de los Monteros; TIEDEMANN, Klaus (ed.). Regulating corporate criminal liability. Heidelberg: Springer, 2014.

WALKER, Gary E. (ed). CLARKE, Lindel D. (ed). The Lehman Brothers Bankruptcy: analyses. New York: Nova, 2012.

WARREN, Danielle E.; GASPAR, Joseph P.; LAUFER, William S. Is formal ethics training merely cosmetic? A study of ethics training and ethical organizational culture. Business Ethics Quartely, vol.24, janeiro de 2014.

WEISSMANN, Andrew. Perspectives on Compliance Programs: The Enron Verdict. Disponível em: $<$ https://jenner.com/system/assets/assets/4866/original/Perspectives.pdf?1320326434> Acesso em 10 de abril de 2015.

WELLNER, Philip A. Effective compliance programs and corporate criminal prosecutions. Cardozo Law Review. New York, vol.27-1, p. 497, Outubro de 2005.

WILLIANS, Mark T. Uncontrolled risk: the lessons of Lehman Brothers and how systemic risk can still bring down the world financial system. New York: McGraw-Hill, 2010. 
YIN, Robert K. Estudo de Caso - Planejamento e Métodos. Porto Alegre: Bookman, 2005.

ZAFFARONI, Eugenio Raúl. O papel do direito penal e a crise financeira. In: SAADDINIZ, Eduardo (org.); BRODOWSKI, Dominik (org.); SÁ, Ana Luiza de (org.). Regulação do abuso no âmbito corporativo: o papel do direito penal na crise financeira. São Paulo: Editora LiberArs, 2015. 